Fábio de Andrade Machado

\title{
Implicações evolutivas da integração morfológica do crânio em Caniformia (Carnivora; Mammalia)
}

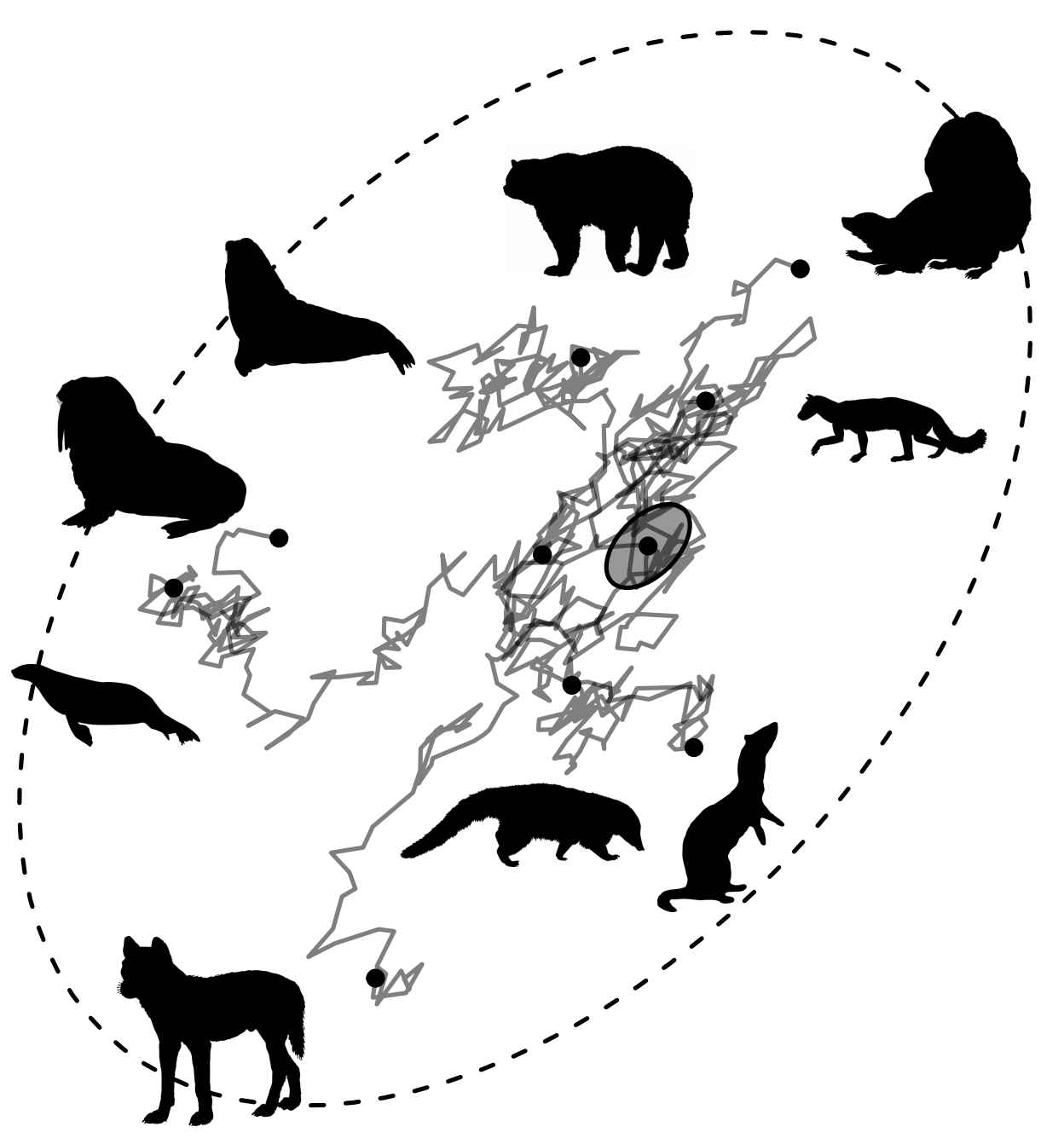

São Paulo

2016 



\section{Fábio de Andrade Machado}

\section{Implicações evolutivas da integração morfológica do crânio em Caniformia (Carnivora; Mammalia)}

Evolutionary consequences of morphological integration in the skull of Caniformia (Carnivora; Mammalia)

Tese apresentada ao Instituto de Biociências da Universidade de São Paulo, para a obtenção de Título de Doutor em Ciências, na Área de Genética e Biologia Evolutiva.

Orientador: Gabriel Henrique Marroig Zambonato

São Paulo

2016 
Machado, Fabio A.

Implicações evolutivas da integração morfológica do crânio em Caniformia (Carnivora; Mammalia)

268 páginas

Tese (Doutorado) - Instituto de Biociências da

Universidade de São Paulo. Departamento de Genética e Biologia Evolutiva.

1. Carnivora

2. Caniformes

3. Morfometria

4. Genética Quantitativa

5. Erro do tipo I

6. Poder estatístico

7. Macroevolução

I. Universidade de São Paulo. Instituto de Biociências. Departamento de Genética e Biologia Evolutiva.

\section{Comissão Julgadora:}

Prof. Dr.

Nome
Prof. Dr.

Nome
Prof. Dr.

Nome
Prof. Dr.

Nome

Prof. Dr.

Nome do Orientador 
Aos meus pais, Francisco e Regina, meus companheiros 
But the historian (...) has to say

"here is the way it looks at present".

(...) It [the theory] is open to change:

you want to come up with the best

tentative model you can, and if

somebody else shoots it down, great!

All we want is to get closer to the truth, which we are never quite going to get to $(\ldots)$. It is kind of a North Star by which we navigate. You are never going to get on board your boat and get to the North Star!

No, it is like a guiding light: you are trying to get closer and closer to it you are trying to get farther and farther out of your ignorance.

But who knows? It is conceivable that somebody might come up with some 
alternative paradigm to evolution. But

if they did, it would have to explain

all the evidence as well or better.

It is kind of doubtful anybody will,

it will be a heck of a boulder to try

to push (...) so I don't expect it

will happen.

But nobody would rule it out because all

results of honest inquiry are based

on this skepticism and contain the

seed of their own demolition. It may

never happen, but you are willing

to see any view.

Robert M. Price 


\section{Agradecimentos}

Em primeiro lugar eu gostaria de agradecer a meu orientador, Gabriel Marroig por há 5 anos ter me acolhido em seu laboratório e ter dado a oportunidade de trabalhar com ele e em conjunto com a fantástica equipe que reuniu sobre sua tutela. Foi um período de intenso aprendizado e amadurecimento que com certeza levarei para sempre comigo.

Agradeço aos meus queridos colegas de laboratório, por terem compartilhado comigo nessa jornada, cada um à sua maneira. À Paula Assis, obrigado por ter me recebido em Berkeley e ter me introduzido na cultura Norte-Americana. À Barbara Costa, pela honestidade e pelo humor ácido. Ao Guilherme Garcia, que presenciou a maior parte deste caminho, agradeço pelas conversas francas e abertas. Metade das vezes que tomávamos um café, eu não queria ou sequer precisava. Ao Alex Hubbe, pelo interesse mútuo pelos fósseis, pela confiança, pelo respeito e por ter me mostrado o caminho quando cheguei no laboratório. Ao Diogo Melo, pelas trocas de ideias, dicas e por ser um colega criativo e desafiador. À Aninha Pavan, pelas conversas sobre filogenias, projetos e, acima de tudo, pelo bom humor. À Anna Penna, pela amizade que começou no laboratório, mas que espero que não termine por lá. À Daniela Rossoni, por estar sempre disposta a aprender em conjunto, a falar e escutar. À Monique Simon, por colocar a qualidade, rigor e clareza acima de tudo. Trabalhar com você foi um prazer enorme, e só posso esperar que possamos voltar a faze-lo. Ao Thiago Zahn, pelo companheirismo em terras distantes e nestas, por sempre estar aberto ao dialogo e a ver outros pontos de vista. É bom saber que mesmo na discordância, e talvez principalmente nela, conseguimos achar pontos em comum. Te agradecer pelos dados que ajudaram na realização desta tese soa um tanto menor, porém necessário.

Agradeço à Universidade de São Paulo (e seus funcionários) pela in- 
fraestrutura, e o suporte fornecido pelo Programa de Pós Graduação de Genética e Biologia Evolutiva. Também contei com o apoio institucional das seguintes instituições Norte-Americanas: University of Massachusetts (Amherst) e Smithonian Institute (Washington). Agradeço principalmente à FAPESP pelas bolsas (auxilio regular e BEPE) que permitiram a realização deste projeto. Agradeço o auxilio da CAPES que me permitiu comparecer a cursos de alta qualidade no exterior. Agradeço ainda ao suporte do Santander (em conjunto com University of California) e do auxilio proporcionado pelo American Museum of Natural History (New York).

Esse trabalho não poderia ter sido realizado sem o acesso à coleções zoológicas que acomodam os espécimes por mim estudados. Assim, devo a enorme gratidão à todos os curadores e administradores de coleções das coleções por mim visitadas: Mario de Vivo e Juliana Gualda do Museu de Zoologia da Universidade de São Paulo (São Paulo); João Oliveira, Luiz Flamarion e Sérgio Maia Vaz do Museu Nacional (Rio de Janeiro); David Flores e Sergio Lucero do Museu Argentino de Ciencias Naturales Bernardino Rivadavia (Buenos Aires); Diego Verzi e Itati Olivares do Museu La Plata (La Plata); Eileen Lacey e Chris Conroy do Museum of Vertebrate Zoology (Berkeley); Nancy B. Simmons, Neil Duncan, Eileen Westwig, Aja Marcato e Eleanor Hoeger da seção de mamíferos e John Flynn, Jin Meng e Judy Galkin da seção de paleontologia do American Museum of Natural History (Nova York); Kris Helgen, Darrin Lunde, Esther Langan e John Ososky do Smithonian Institute (Washington); Bruce Patterson, Bill Stanley (in memorian) da seção de mamíferos e Bill Simpson da seção de paleontologia do Field Museum (Chicago); Hopi Hoekstra e Judith M. Chupasko do Museum of Comparative Zoology (Cambridge); e Ted Daeschler e Ned Gilmore da Academy of Natural Sciences of Drexel University (Philadelphia). Não posso deixar de agradecer especialmente à Betsy Dummont por ter me super- 
visionado durante o período de viagem de coleta de dados nos Estados Unidos, sem o qual esta tese não teria sido realizada.

Durante o longo período de coleta de dados a hospitalidade de diversas pessoas foi indispensável. No Rio de Janeiro, fui recepcionado por Grazielle Giacomo em um barco construído à imagem do Beagle (que forma de começar as viagens de coleta). Em Buenos Aires, meus tios Calu Machado e Juan Arranz me ofereceram teto e carinho na minha primeira incursão em terras distantes. Em Nova York, Silvia Pavan e Pedro Peloso me ofereceram uma casa quando nenhuma mais estava disponível. Em Chicago, Arthur Porto e Emily Robbins dividiram comigo sua casa, sua comida e seus amigos. Em Cambridge, Bruno Medeiros e Tauana Cunha me deram um lar. Em Washington, Daniel Damineli e Maitê Portes me ofereceram um colchão, companhia, amizade, peteca e conversas.

Não posso deixar de agradecer a Celeste Luna, a minha maior surpresa dessa jornada. Gracias por estar conmigo en los momentos buenos y difíciles, por la comprensión, la fuerza, el afecto y la amistad. Por lo que eres. Te quiero mucho mi pequenina.

Por ultimo, agradeço minha família e especificamente ao meu pai, Francisco de Andrade Machado Filho e minha mãe Maria Regina Leitão de Andrade Machado, meus companheiros mais antigos. Passamos por diversas provações e tribulações neste período, mas sempre nos mantendo fortes e unidos. Nunca vou poder colocar em palavras minha gratidão. Sem seu suporte e amor este trabalho teria sido impossível. 
O fenótipo de caracteres complexos é o produto final da inter-relação entre genes, vias ontogenéticas e efeitos ambientais. A variação desses fatores não apenas influencia o fenótipo final, mas também como caracteres covariam e evoluem de forma integrada. A seleção natural pode influenciar a integração entre caracteres, levando a mudança de padrões de correlação ao longo do tempo. Assim, uma visão integrativa e dinâmica de fenótipos complexos é essencial para a compreensão da história evolutiva destas estruturas. Na tese atual investiguei a integração morfológica de caracteres cranianos em Caniformes sob duas perspectivas. Em uma primeira abordagem investiguei o padrão de integração morfológica das espécies a partir da comparação das variâncias e covariâncias dos caracteres. Os resultados evidenciam dois principais pontos. O primeiro é que houve uma considerável estabilidade na covariância entre caracteres ao longo de toda a história evolutiva de Carnivora, sugerindo a manutenção dos padrões de desenvolvimento no grupo como um todo. O segundo ponto é que, apesar desta estabilidade, espécies da família Canidae apresentam modificações em sua integração morfológica que os tornam mais similares entre si e mais dissimilares com os demais Carnivora. Essas diferenças estão relacionadas principalmente com caracteres da região facial, que apresentaram maior flexibilidade evolutiva, maiores correlações entre caracteres, e contêm uma maior proporção da variância em Canidae que nos demais Carnivora. Em uma segunda abordagem investiguei as propriedades estatísticas de dois testes baseados na teoria de genética quantitativa: o teste de regressão de autovalores e o teste de correlação de componentes principais (PCs). Estes testes avaliam a proporcionalidade entre padrões de covariância genética 
e entre-espécies como forma de testar a hipótese nula de deriva genética. Os resultados mostram que o uso de contrastes filogenéticos independentes (PIC) reduz erros do tipo I inflados, principalmente no caso do teste de correlação. Quando PIC são utilizados, o teste de correlação apresenta taxas de erro tipo I nominais para todos os números de espécies. Entretanto, a flutuação do número efetivo populacional $\left(N_{e}\right)$ infla o erro tipo I deste testes. O teste de regressão, apesar de apresentar erro do tipo I inadequado para número de espécies baixo, é robusto a flutuações de $N_{e}$. A redução do número de PCs reduz o erro do tipo I a valores nominais à custa de uma redução no poder do teste. O poder de ambos os testes é similar nos diversos cenários avaliados, com uma leve tendência de maior poder para o teste de correlação em números amostrais mais baixos. Adicionalmente, as famílias de Caniformes foram utilizadas como estudo de caso para ambos testes. Os testes foram realizados com métodos paramétricos e não-paramétricos (simulações) e com e sem PIC. Houve rejeição de deriva para quase todas as famílias, com exceção de Mephitidae e Ursidae. Os testes de regressão baseados em simulações se mostraram consistentes com e sem o uso de PIC, apresentando intervalos de confiança menores que os testes paramétricos. Os resultados da presente tese abrem diversas possibilidades de investigação futura, tanto do ponto de vista empírico (em relação a modificações de Canidae e dos processos evolutivos deste grupo e de Ursidae e Mephitidae), assim como metodológicos (aprofundamento das investigações sobre as propriedades dos métodos para investigações macroevolutivas baseados em genética quantitativa).

Palavras-chave: Carnivora, Caniformes, Morfometria, Genética Quantitativa, Erro do tipo I, Poder estatístico, Macroevolução 


\begin{abstract}
The phenotype of complex characters is the end-product of the interrelations between genes, ontogenetic pathways and environmental effects. The variation in these factors influences not only the final phenotype, but also how characters covary and evolve in an integrated way. Natural selection can influence the interaction among characters, leading to changes in the patterns of integration. Therefore, a integrative and dynamic view of complex phenotypes is essential to the understanding of the evolutionary history of such structures. In the present thesis I investigated the morphological integration of cranial characters in Caniform species in two perspectives. In the first approach I investigated the pattern of morphological integration of the species through the comparison of character variances and covariances. The results of this investigation highlighted two points. The first is that there is considerable stability in the covariance among characters along the evolutionary history of Carnivora, suggesting the maintenance of ontogenetic pathways in the group. The second is that, despite this stability, Canidae species show changes in their morphological integration that make them more similar among each other and more different from the rest of Carnivora. These changes are related mainly to characters from the facial region, which showed a greater evolutionary flexibility, greater correlation among characters, and concentrate a greater proportion of the variance in Canidae than in the rest of Carnivora. In a second approach I evaluated the statistical properties of tests based on quantitative genetics theory: the test of regression of eigenvalues and the test of correlation of principal components (PCs). These tests investigate the proportionality between patterns of genetic and between-species covariance as a way to test the null hypothesis
\end{abstract}


of genetic drift. The results show that the use of phylogenetic independent contrasts (PIC) reduces the inflated type I error, especially in the case of the correlation test. When PIC are employed, the correlation test shows nominal type I error rates for all species sample sizes. However, the oscillation of the effective population size $\left(N_{e}\right)$ inflates type I error rates of these tests. The regression test, despite showing inadequate type I error rates at small species sample sizes, is robust to the oscillation of $N_{e}$. The reduction of the number of PCs reduces type I error rates to nominal values at the expense of statistical power. The power of both tests is similar under different scenarios evaluated, with a slight tendency of the correlation test to perform better at small number of species. Additionally, the Caniform families were used as case studies for both tests. Tests were performed using parametric and non-parametric (simulations) techniques, with and without PIC. The drift hypothesis was rejected for almost all families, with the exception of Mephitidae and Ursidae. The regression tests based on simulations were consistent with and without the use of PIC, showing narrower confidence intervals than the ones for parametric tests. The results of the present thesis open a wide range of future investigation opportunities, both from the empirical (relative to the differences in Canidae patterns of morphological integration or the evolutionary processes underlying Ursidae and Mephitidae diversification) and methodological (further investigations of the properties of the quantitative genetics-based tests for macroevolution) points of view.

Keywords: Carnivora, Caniformes, Morphometrics, Quantitative Genetics, Type I error, Statistical Power, Macroevolution 


\section{Lista de Figuras}

1.1 Efeitos de número variável de loci aditivos em um caráter

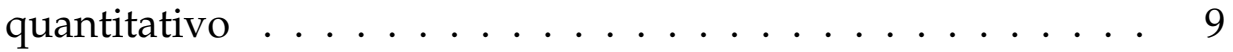

1.2 Exemplos das Famílias de Caniformes . . . . . . . . . . . . 15

1.3 Exemplos de crânios de cada Família de Caniformes . . . . . . 21

2.1 Marcos anatômicos em ambas as vistas digitalizadas sobre o crânio de um espécime de Canis lupus . . . . . . . . . . . . 37

2.2 Esquema de digitalização de crânios . . . . . . . . . . . . . . 45

2.3 Planilha utilizada para a coleta de dados . . . . . . . . . . . . 46

2.4 Representação esquemática do método de Random Skewers para um único gradiente de seleção . . . . . . . . . . . . . . 53

2.5 Repetibilidades empíricas estimadas para todas as espécies com $n>5 \ldots \ldots \ldots \ldots \ldots \ldots$

3.1 Marcos anatômicos mostrados sobre o crânio de um espécime de Canis lupus . . . . . . . . . . . . . . . . . . . 70

3.2 Exemplo do impacto da diferença nas médias dos grupos nas estimativas de matrizes de covariância. . . . . . . . . . . . 74

3.3 Análise de rarefação estimadas por métodos de Monte Carlo e Bootstrap na amostra de Canis lupus . . . . . . . . . 84

3.4 Análise de rarefação de similaridade de matrix . . . . . . . . . 85

3.5 Similaridade de Matrizes por Random Skewers . . . . . . . . . 86 
3.6 Análise de Cluster através de k-medóides . . . . . . . . . . 89

3.7 Magnitude de integração total $\left(\overline{r^{2}}\right.$ das diferentes famílias de

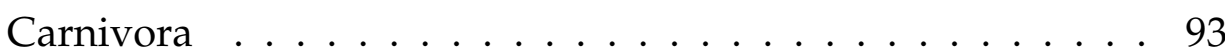

3.8 Relação entre AVG+ e AVG- para diferentes hipóteses modulares ............................ 94

3.9 Relação entre integração morfológica e flexibilidade medida para cada módulo . . . . . . . . . . . . . . . . 95

3.10 Relação entre integração morfológica e porcentagem da variação explicada pelos módulos e por tamanho. . . . . . . . . . 96

3.11 Análise de Cluster através de Medóides sobre matrizes de SRD 98

3.12 Representação grafica dos resultados das análises baseadas em caracteres. . . . . . . . . . . . . . . . . 100

4.1 Filogenia de Caniformes. . . . . . . . . . . . . . . . . . . 134

4.2 Erro do tipo I para testes de deriva de regressão e de correlação141

4.3 Poder estatístico para testes de deriva de regressão e de correlação . . . . . . . . . . . . . . . . . . . . 143

4.4 Erros do tipo I e poder estatistico em análises de clados pequenos com diferentes números de componentes principais . 145

4.5 Taxas de erro do tipo I para simulações com $N_{e}$ variando ao longo da filogenia . . . . . . . . . . . . . . 146

4.6 Teste de deriva por regressão em dados brutos . . . . . . . . . 147

4.7 Teste de deriva por regressão em contrastes independentes . . 147

5.1 Crânio de indivíduos selvagens e domesticados de Vulpes vulpes 168

5.2 Comparação dos crânios de C. familiaris e Borophagus secundus 170

B.1 Comparação das estatísticas de similaridade de matrizes de covariância e correlação . . . . . . . . . . . . . . . 215

B.2 Similaridade de Matrizes de covariância em Caniformes . . 217 
B.3 Similaridade de Matrizes de correlação em Caniformes . . . . 218

B.4 Análise de Coordenadas Principais das similaridades de matrizes por $R S, K r z_{C o r}, P C A_{\text {sim }}$ e $M_{\text {cor }}$ nas matrizes de covariância . . . . . . . . . . . . . . . . 220

B.5 Análise de Coordenadas Principais das similaridades de matrizes por $R S, K r z_{\text {Cor }}, P C A_{\text {sim }}$ e $M_{\text {cor }}$ nas matrizes de correlação221

C.1 Marcos anatômicos utilizados neste estudo exemplificados em um crânio de Canis lupus em vistas lateral e ventral . . . . . 228

C.2 Valores de similaridade por Random Skewers par-a-par para todos 104 taxa. . . . . . . . . . . . . . . . 228

C.3 Análise de coordenadas principais para as distâncias de Riemannian par-a-par entre matrizes de correlação. . . . . . . . . 230

C.4 Distribuição dos valores do índice de integração morfologica. 230

C.5 Poster do Congresso Evolution 2015 . . . . . . . . . . . . . . 233

D.1 Relação entre integração morfológica e AVG- para diferentes hipóteses modulares . . . . . . . . . . . . . . . . 240

D.2 Relação entre integração morfológica e AVG+ para diferentes hipóteses modulares . . . . . . . . . . . . . . . . 241

E.1 Erro do tipo I e poder estatístico para árvores transformadas segundo o modelo "Early Burst". . . . . . . . . . . . . . . . . 252 



\section{Lista de Tabelas}

2.1 Esforço amostral por instituição visitada. . . . . . . . . . . . . 35

2.2 Medidas cranianas . . . . . . . . . . . . . . . . . 48

2.3 Repetibilidade por espécie . . . . . . . . . . . . 50

2.4 Repetibilidade por caráter . . . . . . . . . . . . . . . 51

3.1 Manova não-paramétrica de clusters e taxonomia . . . . . . . 88

3.2 Manova não-paramétrica para RS entre Canidae e o Carnivora não-canideos . . . . . . . . . . . . . . . . . . 91

3.3 Testes de modularidade de hipoteses baseadas em matrizes funcionais. . . . . . . . . . . . . . . . 91

3.4 Diferenças de medidas de Modularidade, flexibilidade e porcentagem de variância entre Caniformes e carnivoros nãocanideos nas diferentes hipoteses modulares . . . . . . . . 92

3.5 Sumário das análises de SRD e NP-MANOVAs em caracteres individuais. . . . . . . . . . . . . . . . . . 101

3.6 Testes-T nas medidas de integração, flexibilidade e variância em caracteres individuais. . . . . . . . . . . . . . . 102

3.7 ANCOVAs nas medidas de integração, flexibilidade e variância em caracteres individuais. . . . . . . . . . . . . . . 103

4.1 Glossario de simbolos utilizados e suas descrições correspondentes. . . . . . . . . . . . . . . . . 129 
4.2 Testes de deriva para as famílias de Caniformes . . . . . . . . 149

4.3 Correlações significativas entre os valores das espécies ou contrastes independentes nos PCs da W . . . . . . . . . . 150

B.1 Correlação entre medidas de similaridade de matrizes . . . . . 216

D.1 Tamanhos amostrais e fatores controlados por espécie analizada236

E.1 Tamanhos amostrais para analises macroevoluticas . . . . . 246

E.2 Sumário do numero de simulações por análise realizadas . . . 255 


\section{Sumário}

1 Introdução 1

Integração morfológica . . . . . . . . . . . . . . . . 2

Genética quantitativa . . . . . . . . . . . . . 8

O Crânio . . . . . . . . . . . . . . . . . . 12

Caniformes .......................... 14

Objetivos e Estrutura da tese . . . . . . . . . . . . . 20

2 Materiais e Metodos 33

Amostragem ............................. 34

Coleções e esforço amostral . . . . . . . . . . . . . . . 34

Marcos anatômicos e medidas . . . . . . . . . . . . . . . 35

Definição e identificação dos Marcos Anatômicos .... . 35

Digitalização dos espécimes . . . . . . . . . . . . . . 42

Unificação das vistas . . . . . . . . . . . . . . . . . . 44

Medidas . . . . . . . . . . . . . . . 4 4

Erro de medição . . . . . . . . . . . . . . . . . . . . . . . 49

Integração morfológica . . . . . . . . . . . . . . . . . . . 51

Cálculo das matrizes . . . . . . . . . . . . . . . 51

Comparação de matrizes . . . . . . . . . . . . . . 52

Repetibilidade de matrizes . . . . . . . . . . . . . 55 
3 Morphological Integration in the skull of Carnivora (Mammalia):

Interplay between modularity, flexibility, patterns and magnitude 61 Introduction . . . . . . . . . . . . . . . . . 62

Materials and Methods . . . . . . . . . . . . . . . . . 67

Sample ........................ 67

Morphometrics and data processing . . . . . . . . . . . 69

The Cheverud Conjecture . . . . . . . . . . . . . 72

Covariance Matrix estimation . . . . . . . . . . . 73

Matrix similarity, repeatability and rarefaction analysis . . . 76

Cluster Analysis . . . . . . . . . . . . . . . . . 78

Modularity, Evolutionary flexibility, magnitude of integration and percentage of variation . . . . . . . . . . . 79

Selection Response Decomposition . . . . . . . . . . . . . 82

Results ....................... 83

Repeatability, rarefaction and minimum sample size . . . . . 83

Matrix similarity and Cluster Analysis . . . . . . . . . . . 84

Modularity, Evolutionary flexibility, magnitude of integration and percentage of variation . . . . . . . . . 90

Selection Response Decomposition and Individual Characters 97 Discussion ............................. 99

Similarity of G among Carnivora . . . . . . . . . . . . . . 99

Difference in Canidae . . . . . . . . . . . . . . 107

4 Error rates of quantitative genetics tests applied to macroevolu$\begin{array}{ll}\text { tionary data } & 125\end{array}$

Introduction . . . . . . . . . . . . . . . 126

Principal Component-Based Tests of Drift . . . . . . . . . . 130

Materials and Methods . . . . . . . . . . . . . . . . 133

Sample, measurements and matrices . . . . . . . . . . 133 
Model of phenotypic evolution . . . . . . . . . . . 135

Type I error rates and Power . . . . . . . . . . . . . . . 136

Variation in $N_{e} \ldots \ldots \ldots \ldots$. . . . . . . . . . 137

Empirical example: Caniform Families . . . . . . . . . . . . . . 138

Results .......................... 139

Type I error and Power . . . . . . . . . . . . . . . . 139

Variation in $N_{e} \ldots \ldots \ldots \ldots \ldots$. . . . . . . . . . 144

Caniformes . . . . . . . . . . . . . . . . . . 144

Discussion . . . . . . . . . . . . . . . . . 148

5 Conclusões 165

Padrão de integração em Canidae e relações com domesticação de C. familiaris . . . . . . . . . . . . . . 166

Testes de Deriva no Contexto de Métodos Filogenéticos Compara-

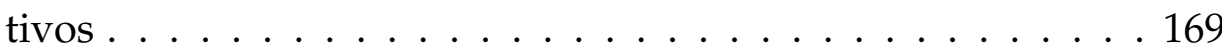

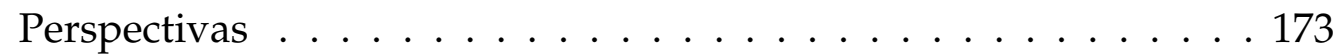

$\begin{array}{lr}\text { Apêndices } & 179\end{array}$

$\begin{array}{ll}\text { A Espécimes } & 181\end{array}$

B Comparação entre medidas de similaridade de matrizes 211

$\begin{array}{ll}\text { C Poster Evolution } 2015 & 225\end{array}$

D Apêndice do Capítulo 3 235

E Apêndice do Capítulo 4 243

Tree transformation . . . . . . . . . . . . . . . 250

$\begin{array}{llr}\text { F Publicações } & 267\end{array}$ 

Capítulo 1

Introdução 


\section{Integração morfológica}

Integração morfológica se refere ao fato de que organismos são compostos por diferentes partes (ou caracteres) que apesentam diferentes graus de interconexão entre si. Esse conceito está intrinsecamente ligado à ideia de que organismos são sistemas formados por elementos individualizados (caracteres) que apresentam associações internas e que se influenciam mutuamente. Os elementos e suas interconexões afetam o comportamento do organismo como um todo, que por sua vez regula a estrutura e relações dos elementos que o compõem (Nagel, 1961). Chamamos a um conjunto de caracteres com níveis variáveis de interconexão entre si de caracteres complexos.

O reconhecimento de que os caracteres dos organismos não variam independentemente é um fenômeno há muito tempo reconhecido por filósofos naturais. Aristóteles em seu Пepı Zóov uopíov ("As partes dos animais") foi o primeiro autor a estabelecer uma metodologia sistemática para avaliar a relação entre as partes dos animais (orgãos, tecidos, fluidos, etc), apontando para a associação entre os elementos como sendo necessária para a produção de uma certa função organísmica (Mayr, 1961). A visão Aristotélica dos organismos como sistemas integrados foi levada ao extremo com Galeno, que em seu De Usu Partium Corporis Humani ("Sobre o uso das partes do corpo humano") publicado no século II, discute não apenas como certas partes contribuem para determinada função, mas também que a composição de um sistema complexo é essenciais para a performance do organismo (Schiefsky, 2007). Em outras palavras, Galeno argumentava, através de uma apresentação abundante de contrafactuais ${ }^{1}$, que mudanças mínimas nas propriedades, organização e configuração das partes dos organismos se-

\footnotetext{
${ }^{1}$ uma afirmação condicional na qual o primeiro enunciado expressa algo contrário aos fatos.
} 
riam prejudiciais para o funcionamento perfeito das funções necessárias ao desenvolvimento, à vida e à reprodução. Galeno era um dos proponentes mais antigos de uma espécie de Design Inteligente ${ }^{2}$ metodológico que via a especificidade funcional (isto é, a conexão específica de partes para a realização de uma função) como evidência de uma força criadora por trás da existência de organismos biológicos. Apesar de hoje serem desconsiderados pela ciência, argumentos como o avançado por Galeno não eram considerados anti-científicos na sua época, sendo Galeno na verdade considerado um dos grandes cientistas da antiguidade (Carrier, 2016).

A ideia de que o organismo é constituído por partes que interagem entre si foi de extrema influência no pensamento de Georges Cuvier, o pai da paleontologia moderna. Cuvier era um grande admirador de Aristóteles e, assim como Galeno, acreditava que as diversas partes do organismo deveriam ser avaliadas em relação a um "todo"integrado, cunhando o que ficou conhecido como "O Princípio de Correlação de Partes":

Se os dentes de um animal são como devem ser, de maneira que ele se alimente com carne, podemos ter certeza sem subsequente investigação que todo o sistema de seus órgãos digestivos é apropriado para esse tipo de alimento; e que todo o esqueleto e os órgãos locomotivos, até mesmo seus órgãos sensoriais, são arranjados de tal maneira a torná-lo hábil para a caça e captura de sua presa. Essas relações são condições necessárias para a existência do animal; se fosse de forma contrária, ele não seria capaz de subsistir.

"Extract from a memoir on an animal of which the bones are found in the plaster stone [pierre à plâtre] around Paris, and which appears no longer to exist alive today"(Cuvier, 1798) reproduzido em (Rudwick, 2008, p. 36)

\footnotetext{
${ }^{2}$ Design inteligente se refere à versão modernizada dos argumentos clássicos de teologia natural aplicados aos organismos biológicos (Scott, 2009).
} 
Assim, Cuvier reconhece não apenas as necessidades fisiológicas para a associação de partes, mas também a associação imposta por necessidades ecológicas, permitindo a interação de elementos pertencentes a diferentes sistemas (como dentes e sistemas digestivo) que não estão necessariamente ligados aos tipos de funções mecânicas e sistêmicas. Cuvier, em concordância com Galeno, via a especificidade funcional das diversas partes do organismo como impeditivos para a transmutação das espécies, considerando o registro fóssil como evidência de sucessivas criações divinas, e não de transformação gradual ao longo do tempo. Apesar disso, seu discurso era particularmente livre de referências diretas a divindades, e seu princípio de correlação era dado mais como uma lei natural do que como ação direta de uma entidade (Rudwick, 2008).

Talvez o expoente mais influente destes conceitos tenha sido Willian Paley, que consolidou o pensamento da teologia natural até o começo do século XIX. Segundo Paley, a complexidade (e beleza) dos organismos não apenas era evidência prima facie da existência de um arquiteto transcendental, ou Deus, mas que o estudo da natureza permitia também examinar as propriedades desta entidade, como sua bondade, unidade e, sobretudo, inteligência (Paley, 1802). Esse pensamento é similar ao exposto por Galeno, de que a especificidade funcional de caracteres complexos era tão grande que só poderia ser algo planejado de antemão e confeccionado com este objetivo em mente: tal planejamento e antevisão, ainda mais quando considerado em escala global, só seria possível se desempenhados por uma divindade com poder para tal. Paley apontava não apenas para como os múltiplos componentes de um sistema se associavam especificamente para a formação dos sistemas biológicos, como também para sua má-formação, como evidência de que alterações poderiam trazer malefícios para o funcionamento dos organismos (Paley, 1802, p.132). Isso reforçaria a ideia de que 
espécies estão perfeitamente adaptadas a seus ambientes e que a mutabilidade das espécies é impossível.

Darwin, baseando-se parcialmente nos trabalhos de Saint-Hilaire, interpretou teratologias (ou má-formações) de maneira diferente. Para Darwin, teratologias não eram essencialmente distintas da variação natural das espécies (Darwin, 1859, p. 22), e evidenciavam a existência de leis de variação, que ele chamou de Correlações de Crescimento, que ditavam que diferentes órgãos se desenvolvem em conjunto (1859, p. 24-25). Uma vez que tais variações nem sempre se relacionavam a partes que apresentam funções similares (1859, p. 131-132), a modificação de um caráter por meio de seleção artificial $(1859$, p. 25) ou natural $(1859$, p. 84) poderia afetar outros caracteres, o que implica que organismos não necessariamente vão apresentar todas suas partes perfeitamente adaptadas $(1859, \text { p. } 130,176)^{3}$. Darwin respondeu aos naturalistas que acreditavam ser a sua teoria a que na verdade implicava que organismos estariam perfeitamente adaptados:

Eles [naturalistas] acreditam que diversas estruturas foram criadas em prol da beleza, para deleite do homem, ou por mera variação. A veracidade de tais doutrinas seria fatal para a minha teoria. Admito plenamente que muitas das estruturas que hoje existem não têm atualmente uma utilidade direta para os seus possuidores. Condições físicas provavelmente têm pouco efeito na estrutura, de certa forma independente de qualquer beneficio proporcionado. A correlação de crescimento com certeza teve um papel mais que importante, e a modificação útil de uma parte vai frequentemente ocasionar em outras partes diversas mudanças de nenhum uso direto. Então, novamente caracteres que an-

\footnotetext{
${ }^{3}$ Darwin também rejeitava a noção de adaptação perfeita com base em observações empíricas, que demonstravam que populações apresentavam variação em caracteres de importância funcional (Bizzo, 2010). Ademais, sua teoria não demandava que organismos fossem em si perfeitamente adaptados, apenas melhor adaptados do que outros organismos na mesma população $(1859$, p. 176)
} 
teriormente eram úteis, ou que anteriormente tinham surgido de correlação de crescimento, ou de outra causa desconhecida, podem reaparecer a partir da lei de reversão, ainda que agora de nenhum uso direto. Os efeitos da seleção sexual, quando exibidos para encantar as fêmeas, podem ser chamados úteis apenas em um sentido forçado. Mas, de longe, o mais importante é que a parte principal da organização de cada ser é simplesmente devido à herança; e, consequentemente, embora cada ser esteja seguramente bem adaptado para o seu lugar na natureza, muitas estruturas agora não têm relação direta com os hábitos de vida de cada espécie.

Darwin (1859, p. 174)

Podemos então ver que em resposta a diversas críticas à sua teoria, seja sobre a impossibilidade de evolução por especifidade funcional, seja por prever adaptação perfeita dos organismos ao seu ambiente, Darwin recorreu a conceitos de integração morfológica. Assim, Darwin reconhece claramente duas causas para a integração morfológica: como consequência de leis de variação por correlação de crescimento e/ou como resultado da ação de seleção natural, seja atualmente ou no passado (1859, p. 133,175).

Durante o século $\mathrm{XX}$, o conceito de integração morfológica se transformou enormemente. Destacam-se nesse momento as contribuições de Darcy Thompson no seu On Growth and Form (1917). Thompson era um crítico da teoria de Darwin, no sentido que esta focava-se em seleção natural, em detrimento de leis de formação, para explicar a forma e estrutura dos organismos:

O morfologista, quando comparando um organismo com outro, descreve a diferença entre eles ponto a ponto, e "caráter"a "caráter". Se ele é forçado de tempos em tempos a admitir a existência de "correlação"entre caracteres (como mostrado por Cuvier há cem anos) e ainda, 
apesar de reconhecer este fato de correlação de forma vaga, como um fenômeno que decorre de causas que, exceto em raras circunstancias, ele não pode investigar; ele então cai rapidamente no habito de pensar e falar de evolução como se ela tivesse prosseguido nas linhas da sua própria descrição, ponto a ponto, caráter a caráter. Mas se, por outro lado, peixes diversos e dissimilares podem ser referenciados como um todo a funções idênticas de sistemas de coordenadas diferentes, este fato por si só vai constituir uma prova de que há uma "lei de crescimento"abrangente que permeia toda a estrutura em sua integridade, $e$ que algumas forças mais ou menos simples e reconhecíveis estiveram atuando.

Thompson (1917, p. 727)

Assim, Thompson é considerado um dos pioneiros do tratamento matemático dessas leis de associação entre caracteres, e de sua implicação para a variação nos organismos vivos. Julian Huxley expandiu o programa de pesquisa de Thompson em seu Problems of Relative Growth (1932), reconhecendo a questão do crescimento diferencial de partes (assim como Thompson) como essencial para a biologia, visto que todos os organismos adquirem sua forma através de crescimento e correlação diferencial de partes.

No livro Morphological Integration, os autores Everett Olson e Robert Miller (1958) argumentaram que a integração e interdependência entre caracteres poderia ser mensurada estatisticamente, através da correlação de medidas obtidas de diferences caracteres. Essa ideia simples, porém poderosa, permitiu testar, como proposto por estudiosos da integração morfológica desde Galeno, se demandas funcionais se refletem em associações de caracteres. Assim, esse livro é considerado um marco no estudo da integração morfológica, delineando a base metodológica do programa de pesquisa da área até os dias de hoje. 
Ainda no século $X X$, diversos autores foram essenciais para o aprofundamento de nossa compreensão da integração morfológica. De maneira geral esses autores argumentaram que os organismos e suas partes deveriam ser compreendidos em termos genéticos, assim trazendo o estudo da integração explicitamente para o âmbito da síntese evolutiva, explicitamente no contexto da genética quantitativa. Abaixo, revejo alguns conceitos básicos desta área e suas interconexões com o conceito de integração morfológica.

\section{Genética quantitativa}

Durante a formulação de sua teoria de evolução por seleção natural, Darwin não pôde recorrer a nenhum mecanismo para explicar a herança de caracteres contínuos e teve que se valer de extensivos exemplos, principalmente de variantes domésticos, de que caracteres dessa natureza eram de fato herdados entre progenitores e descendentes. Apesar dessa lacuna teórica, a redescoberta das leis de Mendel na virada do século XX foi recebida com desconfiança por darwinistas. O motivo disso era que, apesar das leis de Men$\mathrm{del}^{4}$ explicarem a mecânica do funcionamento da herança de caracteres, os tipos de caracteres avaliados por Mendel e priorizados por seus seguidores, os Mendelianos, eram de natureza discreta, ou seja, assumiam estados descontínuos. Nesse contexto, mutações seriam a principal força por trás da evolução, permitindo a criação de novos estados discretos de caracteres que, então, podiam ser selecionados ou descartados (De Vries, 1903; Castle, 1905).

\footnotetext{
${ }^{4}$ (Monaghan e Corcos, 1984)
}

Lei da Pureza dos Gametas Cada gameta carrega apenas um fator (alelo) referente a cada caráter/gene.

Lei da Segregação Independente Para diversos caracteres, os fatores que determinam cada um se segregam independentemente nos gametas. 
Em oposição estavam os Biometristas, seguidores de Darwin que, como ele, viam a variação continua de caracteres como a força motriz da evolução por seleção natural. Enquanto os Mendelianos apresentavam uma base teórica para explicar a herança de caracteres discretos, aos Biometristas restava lidar com o problema da regressão à média de caracteres contínuos. Colocado sucintamente, o problema de regressão à média se baseia na observação de que, em uma população de indivíduos que variam continuamente em um determinado caráter, a média dos valores fenotípicos da prole vai ser mais próxima da média populacional do que da média dos valores dos pais. Esse era um problema para os biometristas, pois parecia sugerir que caracteres contínuos sempre seriam revertidos para um valor ancestral, demandando constante seleção para sua modificação.

A solução para esse dilema foi formalmente desenvolvida por Fisher (1918), que notou que, à medida que o número de genes aditivos que influencia um caráter cresce, a distribuição de valores fenotípicos dos caracteres se aproxima de uma distribuição contínua (Figura 1.1). Ademais, fenótipos foram modelados como sendo a soma de efeitos genéticos e ambientais, implicando que os valores fenotípicos observados não refletem diretamente os valores genotípicos de cada indivíduo. Isso permitiu modelar a seleção em um caráter contínuo $z$ da seguinte forma:

$$
\Delta z=\frac{\sigma_{a}^{2}}{\sigma_{p}^{2}} s
$$

(Lush, 1937) onde $\Delta z$ é a diferença na média do caractere $z$ entre a geração parental e a geração descendente, s é o diferencial de seleção (a diferença entre a média da população total e a população selecionada) e $\sigma_{a}^{2} / \sigma_{p}^{2}$ é a razão entre a variância genética aditiva e a variância fenotípica total, também chamada de herdabilidade $\left(h^{2}\right)$. Esse conceito permitiu compreender a regressão à média como um fenômeno emergente da genética dos caracteres 

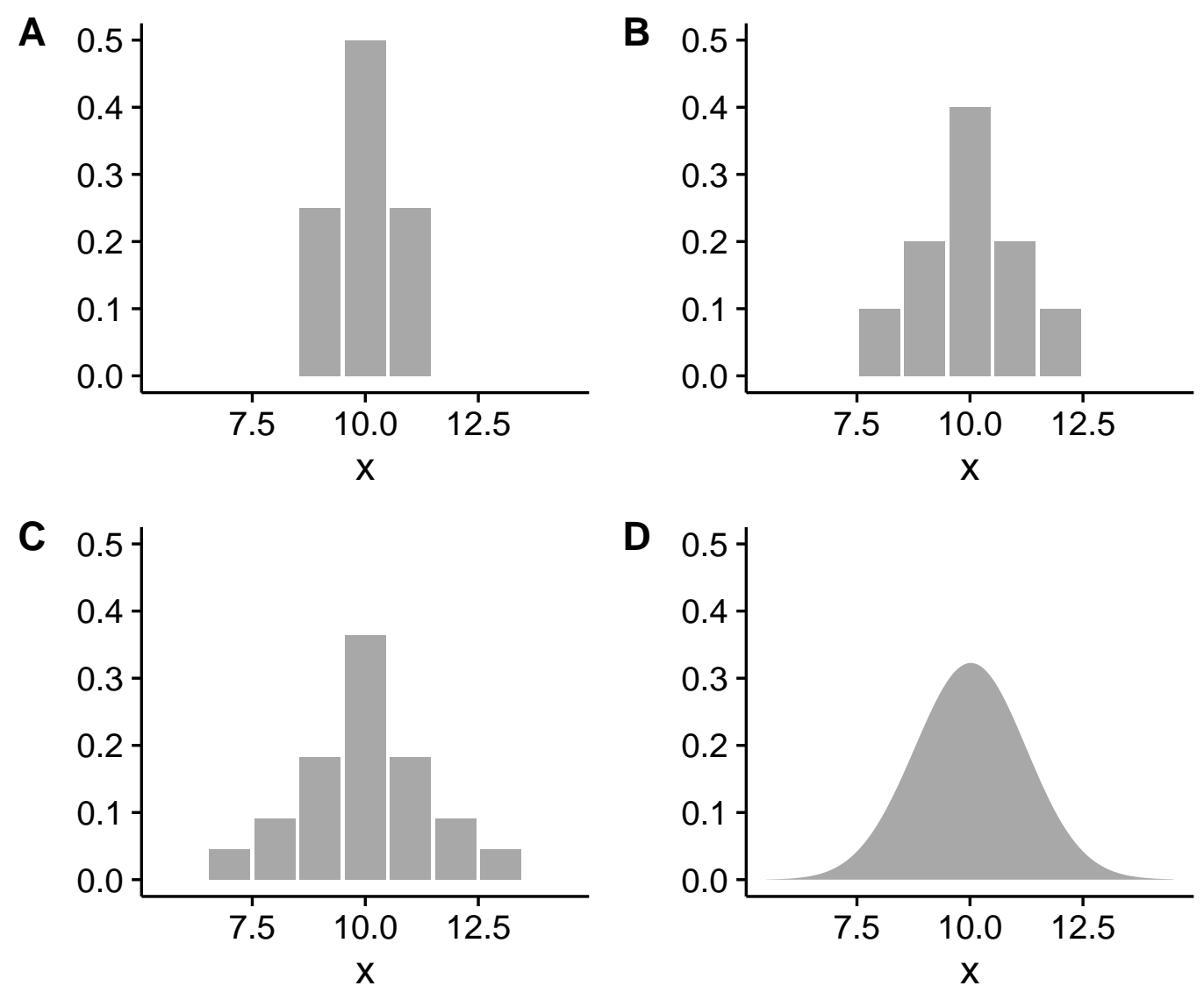

Figura 1.1: Efeitos de número variável de alelos aditivos em um caráter quantitativo em equilíbrio A- Dois alelos em um loci. B- Quatro alelos em dois loci. C- Seis alelos em três loci. D- Um número alto de alelos

contínuos, permitindo ainda a estimativa de parâmetros genéticos a partir de observações empíricas. Esse arcabouço teórico possibilitou modelar caracteres contínuos que podiam evoluir de forma gradual e eram herdados mendelianamente, unificando assim as teorias evolutiva e genética.

No contexto de genética quantitativa, a associação entre partes dos organismos é dada pela existência de desequilíbrio de ligação ${ }^{5}$ entre genes e por pleiotropia ${ }^{6}$ que se expressam em correlação e covariância (genética) entre caracteres (Falconer et al., 1996). Com base neste conceito, Russel Lande revolucionou o estudo de caracteres associados ao traduzir os conceitos de genética quantitativa em um contexto explicitamente multivariado. Segundo

\footnotetext{
${ }^{5}$ associação não-aleatória de alelos em diferente loci.

${ }^{6}$ quando um gene afeta multiplos caracteres.
} 
(Lande, 1979) , a versão multivariada da equação de resposta evolutiva é

$$
\Delta \mathbf{z}=\mathbf{G} \mathbf{P}^{-1} \mathbf{s}
$$

onde $\Delta \mathbf{z}=\left\{\Delta z_{1}, \Delta z_{2}, \ldots \Delta z_{n}\right\}$ é um vetor coluna de diferenças entre médias de $n$ caracteres, G é a matriz $n x n$ de variância-covariância de efeitos aditivos (e.g. elementos $\mathbf{G}_{i i}$ são as variâncias genéticas aditivas do caráter $i$ e elementos $\mathbf{G}_{i j}$ são as covariâncias genéticas aditivas entre os caracteres $i$ e j), $\mathbf{P}$ é a matriz $n x n$ de variância-covariância fenotípica e $\mathbf{s}=\left\{s_{1}, s_{2}, \ldots s_{n}\right\}$ é um vetor de diferenciais de seleção. Pode-se observar que a equação 1.2 é uma tradução direta da equação 1.1 em um contexto multivariado. Lande ainda mostrou que o diferencial de seleção normalizado pela matriz de covariância fenotípica $\left(\mathbf{P}^{-1} \mathbf{s}\right)$ é equivalente ao gradiente da paisagem adaptativa estimado sobre o fenótipo médio da população $(\beta)$. Assim a equação 1.2 pode ser expressa como

$$
\Delta \mathbf{z}=\mathrm{G} \beta
$$

Desta forma representa as direções de maior variação de aptidão, e pode ser estimado como sendo um vetor de coeficientes parciais de regressão múltipla do fenótipo sobre a aptidão (Lande e Arnold, 1983). Assim, $\beta$ pode ser compreendido como a direção e intensidade da seleção sobre a média em uma população.

A equação de Lande também modela a dinâmica de caracteres que não estão sendo selecionados, mas evoluem em decorrência de covariâncias genéticas e seleção indireta em outros caracteres. Para exemplificar isso, considere um sistema de dois caracteres. Para $\beta=\left\{\beta_{1}, \beta_{2}\right\}^{t}$ a resposta evolutiva 
em cada caráter será

$$
\begin{aligned}
\Delta z_{1} & =\mathbf{G}_{11} \beta_{1}+\mathbf{G}_{12} \beta_{2} \\
\Delta z_{2} & =\mathbf{G}_{21} \beta_{1}+\mathbf{G}_{22} \beta_{2}
\end{aligned}
$$

A presença de qualquer covariância genética não-nula entre caracteres $\left(\mathbf{G}_{12}=\mathbf{G}_{21} \neq 0\right)$ implica que a resposta evolutiva em um caráter, mesmo na completa ausência de seleção direta, vai ser influenciada pela seleção presente em outro caráter. De certa forma, essa é uma formalização das ideias de Darwin (1859) para a seleção indireta de caracteres que acata as críticas de Thompson (1917), por explicitamente quantificar a interconexão de partes, e a forma como ela interage com a seleção natural. Assim, o estudo das covariâncias genéticas e fenotípicas codificadas nas matrizes $\mathbf{G}$ e $\mathbf{P}$, de sua variação e de suas consequências para a evolução fenotípica dos diversos grupos é uma escolha natural para o estudo de integração morfológica em sistemas complexos (Cheverud, 1984; Roff, 2002; Steppan et al., 2002; Arnold et al., 2008).

\section{O Crânio}

A morfologia do crânio de mamíferos é o resultado da complexa interação de um número grande de processos ontogenéticos (Hallgrímsson et al., 2007). O crânio pode ser subdividido em três principais regiões: o neurocrânio, derivado do dermatocrânio, o basicrânio, derivado do condrocânio e a região da face, derivada inicialmente do splancnocrânio, recebendo adições subsequentes do dermatocrânio. $\mathrm{O}$ basicrânio é uma região ontogeneticamente estável, crescendo principalmente por ossificação endocon- 
dral, atingindo a morfologia adulta muito cedo durante o desenvolvimento (Farkas et al., 1992). A face e o neurocrânio apresentam desenvolvimentos mais tardios, crescendo principalmente por ossificação intramembranosa nas suturas estimuladas pelo crescimento dos órgãos acomodados nestas regiões (Opperman, 2000). Apesar destes elementos morfológicos apresentarem distintos padrões de desenvolvimento, interações epigenéticas entre regiões do crânio são bastante consistentes entre diferentes linhagens, podendo ser importantes fontes de variação morfológica (Cornette et al., 2014). Assim, visto o grande numero de vias ontogenéticas envolvidas na sua determinação, esperamos que o crânio seja influenciado por um grande número de genes, sendo um modelo ideal para o emprego dos modelos de genética quantitativa. Além disso, visto que tais vias influenciam diversos caracteres ao mesmo tempo, esperamos que existam diferentes graus de associação entre as múltiplas partes, impostas por correlações de crescimento (Darwin, 1859; Thompson, 1917; Huxley, 1932).

A variação nos hábitos de vida das espécies normalmente está associada a diferenças na morfologia craniana. Isso pode se dar através de diferenças na ecomorfologia alimentar, visto que diferentes tipos de itens alimentares impõem diferentes demandas biomecânicas no crânio (e.g. Wroe e Milne, 2007; Christiansen, 2008; Figueirido et al., 2009; Jones e Goswami, 2009; Figueirido et al., 2010; Slater et al., 2009, 2010; Tseng e Wang, 2011; Figueirido et al., 2011, 2013; Meloro et al., 2015; Tseng e Flynn, 2015; Jones et al., 2015). $\mathrm{O}$ crânio também reune parte do sistema nervoso central e a maioria dos órgãos sensoriais, sendo o tamanho relativo destes órgãos importante na determinação da forma final da estrutura (e.g. Radinsky, 1981a,b, 1982; Finarelli, 2008; Finarelli e Flynn, 2009; Van Valkenburgh et al., 2014; Bird et al., 2014; Ranslow et al., 2014). Esses fatores interagem entre si de forma complexa, potencialmente impactando a relação entre seus elementos, se tradu- 
zindo em diferenças na integração morfológica entre as espécies (Cheverud, 1982; Cheverud et al., 1983). Assim, a análise de um grupo com grandes diferenças ecológicas pode nos fornecer importantes informações a respeito da evolução da integração morfológica. Na presente tese, eu investiguei a variação na integração morfológica de um grupo que se encaixa perfeitamente nesta descrição: os Caniformes.

\section{Caniformes}

A ordem Carnivora apresenta uma divisão basal em duas principais subordens: Caniformes e Feliformes. Feliformes contém as famílias viventes Felidae, Viverridae, Hyaenidae, Herpetidae, Eupleridae, Nandiniidae e Prionodontidae. Com exceção de Felidae, Feliformes é considerado um grupo principalmente do velho mundo. Apesar de apresentar formas extremamente especializadas como, por exemplo, os tigres-dentes-de-sabre ou o termitívoro Proteles cristata, são usualmente considerados menos diversos que sua subordem irmã, tanto em termos de número de espécies, quando em ecologia e forma (Goswami, 2010). De fato, classicamente apenas quatro famílias eram reconhecidas (Hyaenidae, Viverridae, Herpestidae e Felidae), evidenciando a grande similaridade fenotípica entre representantes dos diferentes taxons reconhecidos atualmente (Gaubert et al., 2005).

Caniformes (Figura 1.2), por outro lado, é um grupo extremamente diverso em quase todos os sentidos. Podem ser considerados o único grupo de animais (com exceção do homem) que conseguiu dominar todos os continentes, em parte por causa dos Pinipedia. Ecologicamente, é o único táxon de mamíferos que apresenta exemplares extremamente adaptados tanto para o terrestre quanto para o ambiente aquáticos (Goswami, 2010). Caniformes não são exclusivamente carnívoros, como é evidenciado pelos pan- 


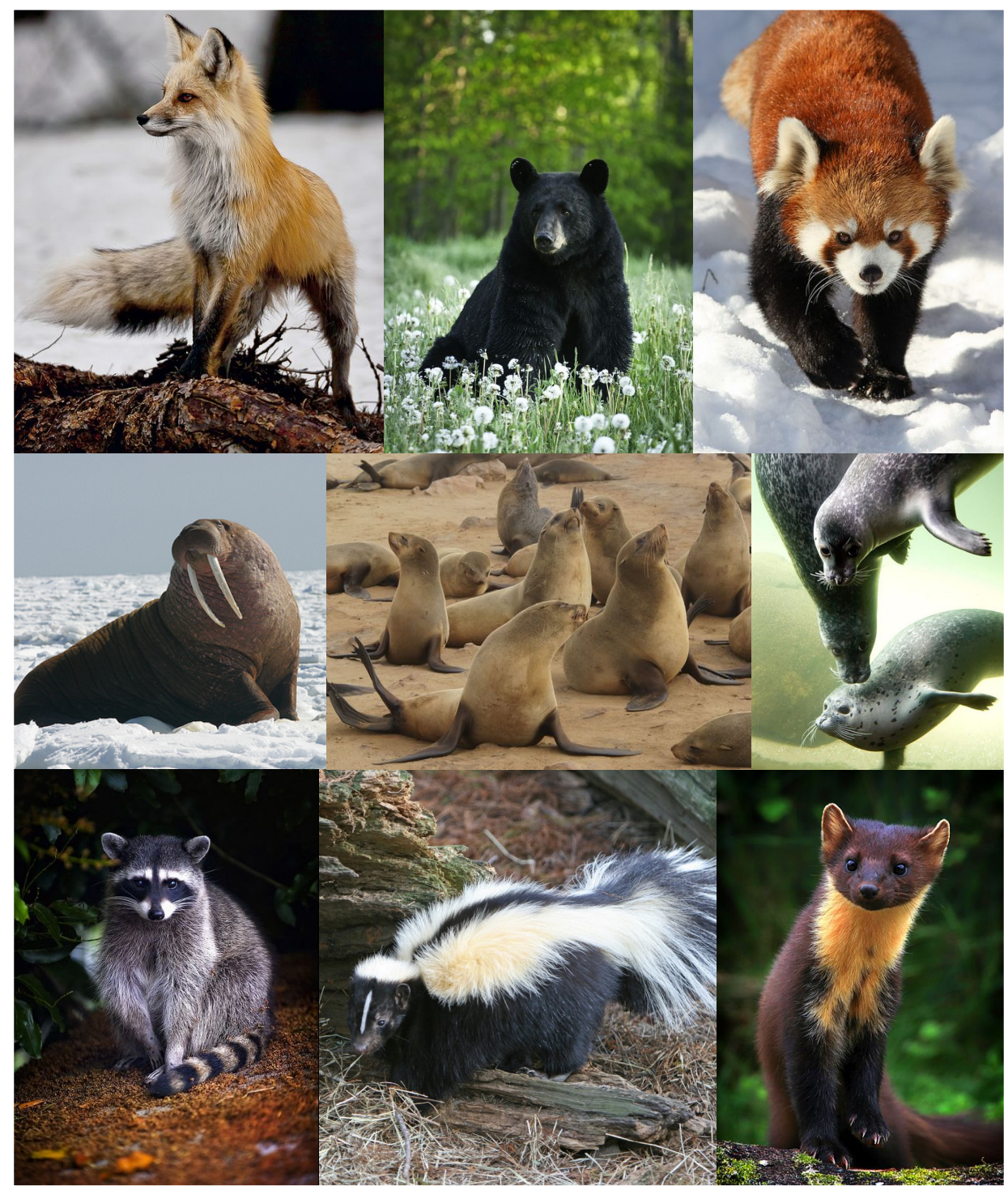

Figura 1.2: Exemplos das Famílias de Caniformes. Linha de cima da esquerda para a direita: Canidae, Ursidae, Ailuridae. Linha do meio da esquerda para a direita (Pinipedia): Odobenidae, Otariidae, Phocidae. Linha de baixo da esquerda para a direita (Musteloidea): Procyonidae, Mephitidae, Mustelidae. 
das gigante (Ailuropoda melanoleuca) e vermelho (Ailurus fulgens), que são animais especializados na ingestão de bambu. Contudo, grande parte das espécies pode ingerir carne ou pelo menos matéria animal como parte da dieta (Kissling et al., 2014). Apesar disso, a dieta dos diferentes grupos varia muito em termos de composição (Van Valkenburgh, 1988; Pineda-Munoz e Alroy, 2014), fator este que parece influenciar o fenótipo dos grupos (Asahara et al., 2016). Adicionalmente, mesmo dentro de grupos especializados em um item alimentar, a estratégia de captura de presas varia consideravelmente, influenciando a interação entre morfologia e ecologia alimentar das espécies (e.g. Van Valkenburgh e Wayne, 1994; Sacco e Van Valkenburgh, 2004; Slater et al., 2009, 2010; Tseng e Wang, 2011; Tseng, 2013; Figueirido et al., 2013; Kienle e Berta, 2015; Tseng et al., 2016).

O táxon Caniformes é composto por 9 famílias atuais:

Canidae é a segunda família mais diversa de Caniformes, com cerca de 37 espécies viventes atualmente descritas, e todas elas pertencem a subfamília Caninae (Tedford et al., 2009). Os Caninae são a única subfamília de canídeos que abandonou a América do Norte (centro de origem de Canidae) povoando a Ásia, Europa, África, América do Sul e, em tempos recentes, Austrália. Canídeos atuais são, em sua maioria, animais de médio a grande porte apresentando variação considerável em socialidade (Bekoff et al., 1981; Biben, 1983). Ecologicamente podem ser considerados em sua maioria generalistas, com algumas espécies podendo ser classificadas como hipercarnívoras (Canis lupus, Lycaon pictus, Cuon alpinus e Speothos venaticus, Slater et al., 2009) e ao menos uma espécie termitivora (Otocyon megalotis, Clark Jr, 2005). Apresentam um pós-crânio especializado para corrida e cursoralidade (Van Valkenburgh, 1985; Andersson, 2005), recaindo sob o crânio a demanda da aquisição e processamento de alimento (Slater et al., 2009). 
Canidae é grupo irmão de todas as demais famílias de Caniformes que, em conjunto, formam o clado Arctoidea (Flynn et al., 2005; Nyakatura e Bininda-Emonds, 2012; Eizirik et al., 2010; Doronina et al., 2015).

Ursidae é a primeira família que se separa das demais de Arctoidea e, de maneira similar a Canidae, todas as espécies viventes de Ursidae pertencem a uma única subfamília (Ursinae). Apesar de apresentarem um número extremamente reduzido de espécies -apenas oito no total- ursídeos apresentam uma enorme diversidade ecológica e morfológica, como pode ser observado pelo contraste entre seus membros especialistas: o panda Ailuropoda melanoleuca, um animal especialista em matéria vegetal dura, o urso-polar Ursus maritimus, um hipercarnívoro exclusivo e o insetívoro Melursus ursinus (Sacco e Van Valkenburgh, 2004). As demais espécies desta família também podem ser consideradas curiosas de um ponto de vista mais amplo por serem onívoros de grande porte (Mattson, 1998; Sacco e Van Valkenburgh, 2004; van Heteren et al., 2015), algo particularmente raro para Carnivora (Carbone et al., 2007; Tucker et al., 2016).

Odobenidae é a primeira das 3 famílias de Pinipedia, a superfamília de Caniformes semiaquáticos. Atualmente Odobenidae é representada por uma única espécie vivente, a morsa Odobenus rosmarus. A morsa é facilmente reconhecida pelo seu grande tamanho, hábito marinho, comportamento gregário e, obviamente, pela presença de enormes caninos em forma de presa. Curiosamente, os demais dentes da morsa são extremamente reduzidos e pouco funcionais, provavelmente em decorrência da especialização para o consumo de moluscos bivalves através de um mecanismo de sucção (Fay, 1985). Apesar das modificações ob- 
servadas na espécie vivente de morsa, os primeiros membros desta família no registro fóssil apresentavam uma morfologia generalizada piscívora, similar à de leões-marinhos (Berta et al., 2007).

Otariidae ou leões-marinhos, são considerados os mais terrestres dos pinipédios, principalmente por apresentarem alguma funcionalidade de seus apêndices posteriores em terra (Berta et al., 2007). As espécies viventes fazem parte de uma irradiação recente que foi extremamente bem sucedida na colonização do Oceano Pacífico e do hemisfério sul, incluindo América do Sul, Africa e Austrália (Yonezawa et al., 2009; Churchill et al., 2014). Os leões-marinhos são considerados conservativos, apresentando uma morfologia piscívora generalista. Dimorfismo sexual é comum no grupo e fortemente associado à presença de haréns, chegando ao extremo no leão-marinho Otaria byronia (Cullen et al., 2014).

Phocidae é a família de pinipédios mais diversificada, apresentando 19 espécies viventes subdivididas em duas subfamílias principais- Phocinae e Monachinae (Fulton e Strobeck, 2010). Phocinae é composta de espécies principalmente piscívoras que habitam os mares do hemisfério norte, incluindo uma espécie dulcícola (Pusa caspica). Monachinae, por outro lado, apresenta uma maior diversidade de formas e hábitos alimentares (Adam e Berta, 2002; Jones e Goswami, 2009; Kienle e Berta, 2015), como evidenciado, por exemplo, pelas espécies especialistas em vertebrados (a foca-leopardo Hydrurga leptonyx) e filtradores de krill (foca-caranguejeira Lobodon carconophaga). Podem ser encontradas nos oceanos Atlântico, Pacifico e Antártico (Fulton e Strobeck, 2010). Diferente de Otariidae, apresentam maior diversidade de estratégias reprodutivas, com espécies monomórficas que se reprodu- 
zem isoladamente e de forma dispersa, à espécies que formam haréns e apresentam dimorphismo sexual extremo, como no gênero de elefantes-marinhos Mirounga (Cullen et al., 2014).

Ailuridae, em conjunto com as próximas três famílias, constitui a superfamília Musteloidea. Ailuridae é a segunda família monotípica de Caniformes, com apenas uma única espécie vivente, o panda vermelho (Ailurus fulgens). Devido a sua convergência morfológica com o panda gigante (Ailuropoda malanoleuca), e seu pequeno tamanho e morfologia generalizada, o posicionamento de Ailurus foi incerto desde o seu descobrimento, sendo reconhecido ora como sendo associado a Ursidae, ora associado à Musteloidea. Filogenias moleculares encerraram o debate, demonstrando que Ailurus é de fato um Musteloidea (Flynn et al., 2005; Eizirik et al., 2010; Morlo e Peigné, 2010; Nyakatura e BinindaEmonds, 2012; Doronina et al., 2015), e que todas as similaridades com o panda gigante são fruto de convergência adaptativa devido ao consumo de matéria vegetal dura (Figueirido et al., 2010, 2013).

Mephitidae foi durante muito tempo considerada uma subfamília de Mustelidae, entretanto evidencias moleculares demonstraram que se tratava de um família à parte, possivelmente irmã do clado formado por Procyonidae e Mustelidae (Flynn et al., 2005; Eizirik et al., 2010; Doronina et al., 2015). São caracterizados pela presença de glândulas de secreção nocivas que podem ser usadas em um "spray"contra predadores (Stankowich et al., 2014). Apesar de pouco diversos (12 espécies) o status taxonômico de muitas espécies ainda é disputado (e.g. Conepatus humboldtii, Schiaffini et al., 2013), evidenciando a falta de revisões no grupo. Em sua maioria, habitam as Américas, com a exceção de Mydaus, originário do Sudeste Asiático. São onívoros oportunistas 
que usam suas fortes garras para cavar atrás de tubérculos, insetos e invertebrados (Nowak, 1999).

Procyonidae é um grupo de 18 espécies de animais onívoros parcialmente ou completamente arborícolas presentes nas Américas do Norte e Sul. Apresentam variação de ecologia e forma, com espécies frugívoras de rosto curto como o kinkajou (Potos flavus) e os olingos (gênero Olingo) e espécies insetívoras de rostro alongado, como os quati (gênero Nasua) (Myers, 2000; Nowak, 1999). Ambos os gêneros de animais de maior porte (Procyon e Nasua) apresentam espécies miniaturizadas relacionadas à invasão de ambientes insulares (Procyon pygmaeus, de Villa-Meza et al., 2011) e de altitude (espécies do subgênero Nasuella, Helgen et al., 2009).

Mustelidae é a família mais diversa de Carnivora, contendo 56 espécies viventes, estando presentes em todos os continentes do mundo, com a exceção da Austrália, Antártica e ilhas oceânicas (Wilson e Reeder, 2005). São principalmente carnívoros, explorando uma enorme diversidade de itens alimentares. Apresentam diferentes graus de especialização, como o hipercarnívoro Carcaju (Gulo gulo), capaz de abater presas até 5 vezes o seu tamanho (Pasitschniak-Arts e Larivière, 1995), ou a lontra marinha (Enhydra lutris), que se utiliza de ferramentas para quebrar invertebrados marinhos mais resistentes (Estes, 2001; Wilson e Reeder, 2005). Talvez o Carnívora mais especializado seja o Mustela nigripes, que se alimenta quase que exclusivamente de uma única espécie de roedor, o cão-da-pradaria (Cynomys ludovicianus; Hillman e Clark, 1980). Mustelidae é caracterizada pela presença de um corpo mais alongado, pernas posteriores mais curtas, tamanho reduzido e rostro pouco alongado. Esse padrão corpóreo permitiu a invasão dos 
mais diversos habitats, com formas escaladoras (e.g. Martes), semifossoriais (e.g. Mustela) e semi aquáticas (as lontras, Lutrinae).

\section{Objetivos e Estrutura da tese}

O objetivo da presente tese é avaliar as consequências evolutivas da variação do padrão de integração morfológica em Caniformes. Especificamente, esse objetivo pode ser decomposto em duas perguntas específicas que são abordadas em capítulos distintos.

No Capítulo 3 intitulado "Morphological Integration in the skull of Carnivora (Mammalia): Interplay between modularity, flexibility, patterns and magnitude"apresento uma análise da diversidade de padrões de integração morfológica em Carnivora. Estudos prévios de integração morfológica em mamíferos tem demonstrado que o padrão de covariância é surpreendentemente conservado para o grupo como um todo (Marroig e Cheverud, 2001; Oliveira et al., 2009; Shirai e Marroig, 2010; Marroig e Cheverud, 2010; Hubbe et al., 2016; Haber, 2016), provavelmente em decorrência da estabilidade de rotas de desenvolvimento (Cheverud, 1982, 1984). Carnivora, especificamente, foi avaliada no contexto de genética quantitativa (Porto et al., 2009, 2013), mas tais análises foram restritas a no máximo quatro espécies, evidenciando a similaridade no padrão de covariância destas espécies com o de grupos pertencentes a outras ordens. Análises especificas de clados menos inclusivos tem revelado a presença de diferenças pontuais que podem ser informativas (e.g Oliveira et al., 2009; Shirai e Marroig, 2010; Hubbe et al., 2016; Haber, 2016), o que justificaria uma investigação mais aprofundada do grupo. Inicialmente esse capítulo trataria apenas da comparação entre especies de Caniformes, porém resultados preliminares apontaram que existia uma distinção em Canidae (Apêndices B e C). Visto que Canidae é grupo 


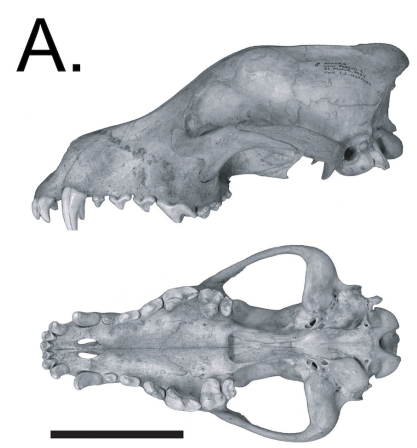

D.
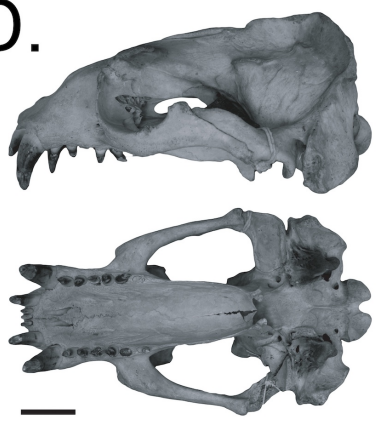

E.

B.
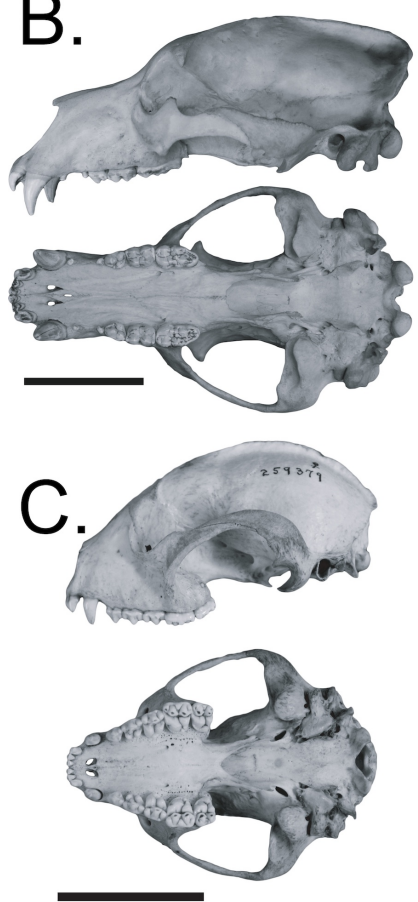
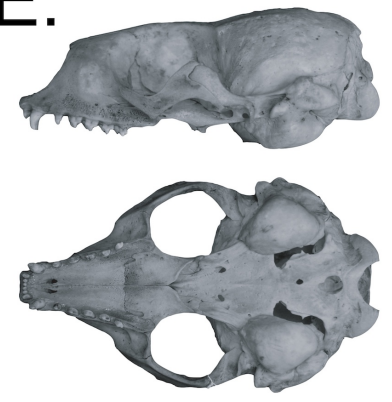

$\mathrm{F}$.

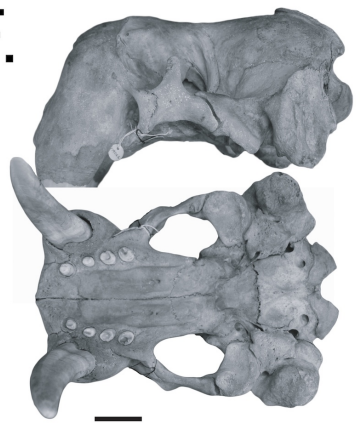

G.

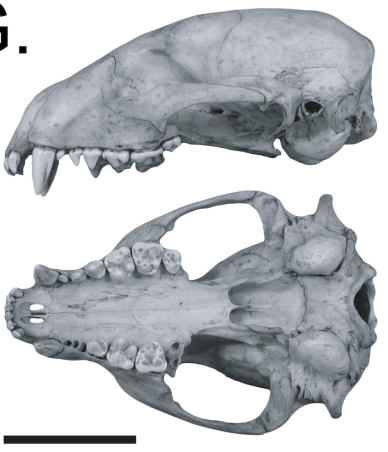

$\mathrm{H}$.

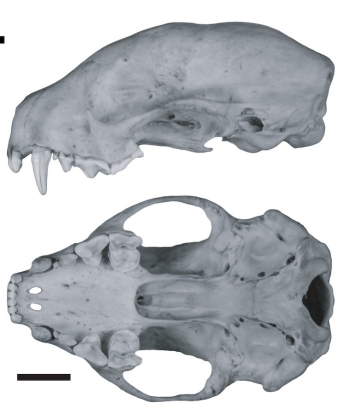

I.
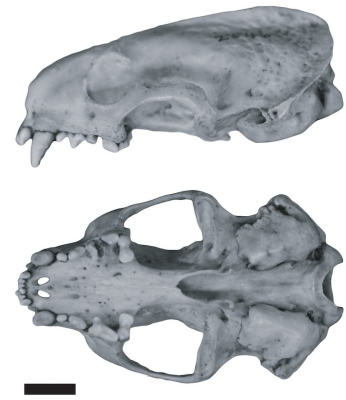

Figura 1.3: Exemplos de crânios de cada Família de Caniformes. A- Canidae (Canis lupus -MNRJ32366). B- Ursidae (Ursus arctos- MVZ437). CAiluridae (Ailurus fulgens- USNM259379). D- Otariidae (Otaria flavecensAMNH73120). E- Phocidae (Phoca hispida- MVZ123999). F- Odobenidae (Odobenus rosmarus- MVZ119066). G- Procyonidae (Procyon cancrivorousMZUSP19794). H- Mephitidae (Mephitis macroura- FMNH5432). I- Mustelidae (Mustela putorius- AMNH2546). 
irmão das demais famílias de Caniformes, restava a dúvida de se o padrão observado nessa família era plesiomórfico, e logo similar a Feliformes, ou derivado, sendo exclusivo de Canidae. Sendo assim, o escopo deste capítulo foi expandido para avaliar Carnivora como um todo com a utilização de dados de Feliformes coletados por um colega de laboratório (Zahn, 2016).

No Capítulo 4 intitulado "Error rates of quantitative genetics tests applied to macroevolutionary data"apresento uma investigação dos aspectos estatísticos de testes de genética quantitativa em contextos macroevolutivos. Esse métodos confrontam a variação intra e interespecifica de forma a avaliar a hipótese nula de deriva genética como sendo suficiente para explicar o padrão de variação observado entre espécies (Lande, 1979; Ackermann e Cheverud, 2004). O objetivo deste capítulo foi investigar as propriedades estatísticas (erro do tipo I e poder) de dois testes específicos, um baseado na proporcionalidade de variâncias nas escalas intra e interespecifica (teste de regressão) e outro baseado no surgimento de correlações entre espécies em combinações de caracteres que são independentes intraespecificamente (teste de correlação; Ackermann e Cheverud, 2004; Marroig e Cheverud, 2004). O erro do tipo I para o teste de regressão foi avaliado previamente em duas publicações. Ackermann e Cheverud (2004) passageiramente citam que o erro do tipo I foi verificado por simulações, mas não oferece nenhuma descrição detalhada dos parâmetros empregados. Prôa et al. (2013) realizam um estudo inteiramente voltado para avaliar a adequação da utilização de matrizes fenotípicas $\mathbf{P}$ como substituto de $\mathbf{G}$ para testes de regressão e mostram que, quando ambas matrizes são similares, o teste apresenta erros do tipo I adequados. Aqui eu expando essas investigações, investigando as propriedades não apenas do teste de regressão, mas também o de correlação em um contexto comparativo, avaliando e mensurando o impacto de dependência filogenética, erro amostral e variação demográfica no erro do 
tipo I e poder.

Ambos capítulos citados acima foram produzidos em inglês, em formato de artigo. A tese ainda conta com um capítulo metodológico (Capítulo 2) que delineia os métodos empregados, amostra total e análises preliminares, um capítulo de conclusões (Capítulo de 5) e cinco apêndices. O Apêndice A traz a lista completa de espécimes analisados. $\mathrm{O}$ apêndice $\mathrm{B}$ traz uma comparação de diferentes métodos para a análise da similaridade de matrizes de covariância e correlação. $O$ apêndice $C$ é o pôster apresentado no congresso Evolution 2015, que contém alguns resultados preliminares que ajudaram na tomada de decisões subsequentes no desenvolvimento da tese. Os Apêndices D e E são os apêndices que contêm o material suplementar dos Capítulos 3 e 4, respectivamente. Por fim, o Apêndice F contêm as publicações aceitas durante o desenvolvimento da tese. 


\section{Referências Bibliográficas}

Ackermann, R. R. e Cheverud, J. M. (2004). Detecting genetic drift versus selection in human evolution. Proceedings of the National Academy of Sciences of the United States of America, 101(52):17946-17951.

Adam, P. J. e Berta, A. (2002). Evolution of prey capture strategies and diet in the Pinnipedimorpha (Mammalia, Carnivora). 4:83-107.

Andersson, K. (2005). Were there pack-hunting canids in the Tertiary, and how can we know? Paleobiology, 31(1):56-72.

Arnold, S. J., Bürger, R., Hohenlohe, P. A., Ajie, B. C., e Jones, A. G. (2008). Understanding the evolution and stability of the G-matrix. Evolution, 62(10):2451-2461.

Asahara, M., Saito, K., e Kishida, T. (2016). Unique pattern of dietary adaptation in the dentition of Carnivora: its advantage and developmental origin. Proceedings of the Royal Society of London. Series B, Biological Sciences, 283(1832):20160375.

Bekoff, M., Diamond, J., e Mitton, J. B. (1981). Life-History Patterns and Sociality in Canids - Body Size, Reproduction, and Behavior. Oecologia, 50(3):386-390.

Berta, A., Sumich, J. L., e Kovacs, K. M. (2007). Marine Mammals : Evolutionary Biology. Academic Press, San Diego.

Biben, M. (1983). Comparative ontogeny of social behaviour in three South American canids, the maned wolf, crab-eating fox and bush dog: implications for sociality. Animal Behaviour, 31(3):814-826.

Bird, D. J., Amirkhanian, A., Pang, B., e Van Valkenburgh, B. (2014). Quantifying the cribriform plate: influences of allometry, function, and phylogeny in Carnivora. The Anatomical Record Part A: Discoveries in Molecular, Cellular, and Evolutionary Biology, 297(11):2080-2092.

Bizzo, N. M. V. (2010). Darwin e o Rompimento com a Teologia Natural de Paley. Brazilian Geographical Journal: Geosciences and Humanities research medium, 1(1):21-32.

Carbone, C., Teacher, A., e Rowcliffe, J. (2007). The costs of carnivory. PLoS Biology, 5(2):363-368.

Carrier, R. (2016). Science Education in the Early Roman Empire. Pitchstone Publishing (US\&CA).

Castle, W. E. (1905). The Mutation Theory of Organic Evolution, from the Standpoint of Animal Breeding. Science, 21(536):521-525. 
Cheverud, J. M. (1982). Phenotypic, genetic, and environmental morphological integration in the cranium. Evolution, 36(3):499-516.

Cheverud, J. M. (1984). Quantitative genetics and developmental constraints on evolution by selection. Journal of Theoretical Biology, 110(2):155171.

Cheverud, J. M., Rutledge, J., e Atchley, W. (1983). Quantitative genetics of development: genetic correlations among age-specific trait values and the evolution of ontogeny. Evolution, 37(5):895-905.

Christiansen, P. (2008). Evolutionary changes in craniomandibular shape in the great cats (Neofelis Griffith and Panthera Oken). Biological Journal of the Linnean Society, 95(4):766-778.

Churchill, M., Boessenecker, R. W., e Clementz, M. T. (2014). Colonization of the Southern Hemisphere by fur seals and sea lions (Carnivora: Otariidae) revealed by combined evidence phylogenetic and Bayesian biogeographical analysis. Zoological Journal of the Linnean Society, 172(1):200-225.

Clark Jr, H. (2005). Otocyon megalotis. Mammalian Species, 766:1-5.

Cornette, R., Tresset, A., e Herrel, A. (2014). The shrew tamed by Wolff's law: Do functional constraints shape the skull through muscle and bone covariation? Journal of Morphology, 276(3):301-309.

Cullen, T. M., Fraser, D., Rybczynski, N., e Schröder-Adams, C. (2014). Early evolution of sexual dimorphism and polygyny in Pinnipedia. Evolution, 68(5):1469-1484.

Darwin, C. (1859). On the Origin of Species by Means of Natural Selection. John Murray, London.

de Villa-Meza, A., Avila-Flores, R., Cuarón, A. D., e Valenzuela-Galván, D. (2011). Procyon pygmaeus (Carnivora: Procyonidae). Mammalian Species, 43(1):87-93.

De Vries, H. (1903). Die mutationstheorie: Versuche und beobachtungen über die entstehung von arten im pflanzenreich, volume 2 . Veit $\{\&$ comp.

Doronina, L., Churakov, G., Shi, J., Brosius, J., Baertsch, R., Clawson, H., e Schmitz, J. (2015). Exploring Massive Incomplete Lineage Sorting in Arctoids (Laurasiatheria, Carnivora). Molecular Biology and Evolution, 32(12):3194-3204.

Eizirik, E., Murphy, W. J., Koepfli, K.-P., Johnson, W. E., Dragoo, J. W., Wayne, R. K., e OBrien, S. J. (2010). Pattern and timing of diversification of the mammalian order Carnivora inferred from multiple nuclear gene sequences. Molecular Phylogenetics and Evolution, 56(1):49-63.

Estes, J. (2001). Enhydra lutris. Mammalian Species, 133:1-8. 
Falconer, D. S., Mackay, T. F., e Frankham, R. (1996). Introduction to quantitative genetics. Pearson Education Limited, Essex.

Farkas, L. G., Posnick, J. C., e Hreczko, T. M. (1992). Growth patterns of the face: a morphometric study. The Cleft Palate-Craniofacial Journal, 29(4):308315.

Fay, F. H. (1985). Odobenus rosmarus. Mammalian Species, 238:1-7.

Figueirido, B., Palmqvist, P., e Pérez-Claros, J. A. (2009). Ecomorphological correlates of craniodental variation in bears and paleobiological implications for extinct taxa: an approach based on geometric morphometrics. Journal of Zoology, 277(1):70-80.

Figueirido, B., Serrano-Alarcón, F. J., e Palmqvist, P. (2011). Geometric morphometrics shows differences and similarities in skull shape between the red and giant pandas. Journal of Zoology, 286(4):293-302.

Figueirido, B., Serrano-Alarcón, F. J., Slater, G. J., e Palmqvist, P. (2010). Shape at the cross-roads: homoplasy and history in the evolution of the carnivoran skull towards herbivory. Journal of Evolutionary Biology, 23(12):2579-2594.

Figueirido, B., Tseng, Z. J., e Martín-Serra, A. (2013). Skull shape evolution in durophagous carnivorans. Evolution, 67(7):1975-1993.

Finarelli, J. A. (2008). Testing hypotheses of the evolution of encephalization in the Canidae (Carnivora, Mammalia). Paleobiology, 34(1):35-45.

Finarelli, J. A. e Flynn, J. J. (2009). Brain-size evolution and sociality in Carnivora. Proceedings of the National Academy of Sciences of the United States of America, 106(23):9345-9349.

Fisher, R. A. (1918). XV.-The correlation between relatives on the supposition of Mendelian inheritance. Transactions of the royal society of Edinburgh, 52(02):399-433.

Flynn, J., Finarelli, J., Zehr, S., Hsu, J., e Nedbal, M. (2005). Molecular phylogeny of the Carnivora (Mammalia): assessing the impact of increased sampling on resolving enigmatic relationships. Systematic Biology, 54(2):317.

Fulton, T. L. e Strobeck, C. (2010). Multiple fossil calibrations, nuclear loci and mitochondrial genomes provide new insight into biogeography and divergence timing for true seals (Phocidae, Pinnipedia). Journal of Biogeography, 37:814-829.

Gaubert, P., Wozencraft, W. C., Cordeiro-Estrela, P., e Veron, G. (2005). Mosaics of Convergences and Noise in Morphological Phylogenies: What's in a Viverrid-Like Carnivoran? Systematic Biology, 54(6):865-894. 
Goswami, A. (2010). Introduction to carnivora. Em Goswami, A. e Friscia, A., editores, Carnivoran Evolution. New views on phylogeny, form and function, pgs. 1-24. Cambridge University Press.

Haber, A. (2016). Phenotypic Covariation and Morphological Diversification in the Ruminant Skull. The American Naturalist, 187(5):576-591.

Hallgrímsson, B., Lieberman, D., Young, N., Parsons, T., e Wat, S. (2007). Evolution of covariance in the mammalian skull. Em Novartis Foundation Symposium, pgs. 164-190. John Wiley, Chichester; New York.

Helgen, K. M., Kays, R., e Helgen, L. (2009). Taxonomic boundaries and geographic distributions revealed by an integrative systematic overview of the mountain coatis, Nasuella (Carnivora: Procyonidae). Small Carnivore Conservation, 41:65-74.

Hillman, C. N. e Clark, T. W. (1980). Mustela nigripes. Mammalian Species, 126:1-3.

Hubbe, A., Melo, D., e Marroig, G. (2016). A case study of extant and extinct Xenarthra cranium covariance structure: implications and applications to paleontology. Paleobiology, 42(3):465-488.

Huxley, J. S. (1932). Problems of Relative Growth - Primary Source Edition. Nabu Press.

Jones, K. E. e Goswami, A. (2009). Quantitative analysis of the influences of phylogeny and ecology on phocid and otariid pinniped (Mammalia; Carnivora) cranial morphology. Journal of Zoology, 280(3):297-308.

Jones, K. E., Smaers, J. B., e Goswami, A. (2015). Impact of the terrestrialaquatic transition on disparity and rates of evolution in the carnivoran skull. BMC Evolutionary Biology, 15(8):1-19.

Kienle, S. S. e Berta, A. (2015). The better to eat you with: the comparative feeding morphology of phocid seals (Pinnipedia, Phocidae). 228(3):396413.

Kissling, W. D., Dalby, L., Fløjgaard, C., Lenoir, J., Sandel, B., Sandom, C., Trøjelsgaard, K., e Svenning, J.-C. (2014). Establishing macroecological trait datasets: digitalization, extrapolation, and validation of diet preferences in terrestrial mammals worldwide. Ecology and Evolution, $4(14): 2913-2930$.

Lande, R. (1979). Quantitative genetic analysis of multivariate evolution, applied to brain: body size allometry. Evolution, 33(1):402-416.

Lande, R. e Arnold, S. J. (1983). The measurement of selection on correlated characters. Evolution, 37(6):1210-1226.

Lush, J. L. (1937). Animal breeding plans. Ames. 
Marroig, G. e Cheverud, J. M. (2001). A comparison of phenotypic variation and covariation patterns and the role of phylogeny, ecology, and ontogeny during cranial evolution of New World monkeys. Evolution, 55(12):25762600.

Marroig, G. e Cheverud, J. M. (2004). Did natural selection or genetic drift produce the cranial diversification of neotropical monkeys? The American Naturalist, 163(3):417-428.

Marroig, G. e Cheverud, J. M. (2010). Size As A Line Of Least Resistance II: Direct Selection On Size Or Correlated Response Due To Constraints? Evolution, 64(5):1470-1488.

Mattson, D. J. (1998). Diet and morphology of extant and recently extinct northern bears. Ursus, 10:479-496.

Mayr, E. (1961). Cause and effect in biology. Science, 134(3489):1501-1506.

Meloro, C., Clauss, M., e Raia, P. (2015). Ecomorphology of Carnivora challenges convergent evolution. Organisms Diversity \& Evolution, 15(4):711720 .

Monaghan, F. e Corcos, A. (1984). On the origins of the Mendelian laws. Journal of Heredity.

Morlo, M. e Peigné, S. (2010). Molecular and morphological evidence for Ailuridae and a review of its genera. Em Carnivora Evolution. Carnivoran Evolution: New views on phylogeny.

Myers, P. (2000). "Procyonidae"(On-line), Animal Diversity Web.

Nagel, E. (1961). The structure of science: Problems in the logic of scientific explanation.

Nowak, R. M. (1999). Walker's Mammals of the World, volume 1. JHU Press.

Nyakatura, K. e Bininda-Emonds, O. R. P. (2012). Updating the evolutionary history of Carnivora (Mammalia): a new species-level supertree complete with divergence time estimates. BMC Biology, 10(12):1-31.

Oliveira, F. B. d., Porto, A., e Marroig, G. (2009). Covariance structure in the skull of Catarrhini: a case of pattern stasis and magnitude evolution. Journal of Human Evolution, 56(4):417-430.

Olson, E. C. e Miller, R. L. (1958). Morphological integration. University of Chicago Press, Chicago and Longon.

Opperman, L. (2000). Cranial sutures as intramembranous bone growth sites. Developmental Dynamics, 219(4):472-485.

Paley, W. (1802). Natural theology; or, evidences of the existence and attributes of the Deity. 
Pasitschniak-Arts, M. e Larivière, S. (1995). Gulo gulo. Mammalian Species, 499:1-10.

Pineda-Munoz, S. e Alroy, J. (2014). Dietary characterization of terrestrial mammals. Proceedings of the Royal Society of London. Series B, Biological Sciences, 281(1789):20141173-20141173.

Porto, A., Oliveira, F. B. d., Shirai, L. T., Conto, V., e Marroig, G. (2009). The Evolution of Modularity in the Mammalian Skull I: Morphological Integration Patterns and Magnitudes. Evolutionary Biology, 36(1):118-135.

Porto, A., Shirai, L. T., Oliveira, F. B. d., e Marroig, G. (2013). Size Variation, Growth Strategies, And The Evolution Of Modularity In The Mammalian Skull. Evolution, 67(11):3305-3322.

Prôa, M., O’higgins, P., e Monteiro, L. R. (2013). Type I error rates for testing genetic drift with phenotypic covariance matrices: a simulation study. Evolution, 67(1):185-195.

Radinsky, L. B. (1981a). Evolution of skull shape in carnivores: 1. Representative modern carnivores. Biological Journal of the Linnean Society, 15(4):369-388.

Radinsky, L. B. (1981b). Evolution of skull shape in carnivores: 2. Additional modern carnivores. Biological Journal of the Linnean Society, 16(4):337-355.

Radinsky, L. B. (1982). Evolution of skull shape in carnivores; 3, The origin and early radiation of the modern carnivore families. Paleobiology, 8(3):177-195.

Ranslow, A. N., Richter, J. P., Neuberger, T., Van Valkenburgh, B., Rumple, C. R., Quigley, A. P., Pang, B., Krane, M. H., e Craven, B. A. (2014). Reconstruction and morphometric analysis of the nasal airway of the whitetailed deer (Odocoileus virginianus) and implications regarding respiratory and olfactory airflow. The Anatomical Record Part A: Discoveries in Molecular, Cellular, and Evolutionary Biology, 297(11):2138-2147.

Roff, D. (2002). Comparing G Matrices: A Manova Approach. Evolution, pgs. 1286-1291.

Rudwick, M. J. (2008). Georges Cuvier, fossil bones, and geological catastrophes: new translations and interpretations of the primary texts. University of Chicago Press.

Sacco, T. e Van Valkenburgh, B. (2004). Ecomorphological indicators of feeding behaviour in the bears (Carnivora: Ursidae). Journal of Zoology, 263(1):41-54.

Schiaffini, M. I., Gabrielli, M., Prevosti, F. J., Cardoso, Y. P., Castillo, D., Bo, R., Casanave, E., e Lizarralde, M. (2013). Taxonomic status of southern 
South American Conepatus (Carnivora: Mephitidae). Zoological Journal of the Linnean Society, 167(2):327-344.

Schiefsky, M. J. (2007). Galen's teleology and functional explanation. Oxford studies in ancient philosophy.

Scott, E. C. (2009). Creationism, Ideology, and Science.

Shirai, L. T. e Marroig, G. (2010). Skull modularity in neotropical marsupials and monkeys: size variation and evolutionary constraint and flexibility. Journal of Experimental Zoology Part B: Molecular and Developmental Evolution, 314B(8):663-683.

Slater, G. J., Dumont, E. R., e Van Valkenburgh, B. (2009). Implications of predatory specialization for cranial form and function in canids. Journal of Zoology, 278(3):181-188.

Slater, G. J., Figueirido, B., Louis, L., Yang, P., e Van Valkenburgh, B. (2010). Biomechanical consequences of rapid evolution in the polar bear lineage. PLOS ONE, 5(11):e13870.

Stankowich, T., Haverkamp, P. J., e Caro, T. (2014). Ecological drivers of antipredator defenses in carnivores. Evolution, 68(5):1415-1425.

Steppan, S. J., Phillips, P. C., e Houle, D. (2002). Comparative quantitative genetics: evolution of the $\mathrm{G}$ matrix. Trends in ecology $\mathcal{E}$ evolution (Personal edition), 17(7):320-327.

Tedford, R. H., Wang, X., e Taylor, B. E. (2009). Phylogenetic Systematics of the North American Fossil Caninae (Carnivora: Canidae). Bulletin of the American Museum of Natural History, 325:1-218.

Thompson, D. W. (1917). On growth and form. On growth and form.

Tseng, Z. J. (2013). Testing Adaptive Hypotheses of Convergence with Functional Landscapes: A Case Study of Bone-Cracking Hypercarnivores. PLOS ONE, 8(5):e65305.

Tseng, Z. J. e Flynn, J. J. (2015). An integrative method for testing formfunction linkages and reconstructed evolutionary pathways of masticatory specialization. Journal of The Royal Society Interface, 12(107):1-10.

Tseng, Z. J., Grohé, C., e Flynn, J. J. (2016). A unique feeding strategy of the extinct marine mammal Kolponomos: convergence on sabretooths and sea otters. Proceedings of the Royal Society of London. Series B, Biological Sciences, 283(1826):20160044-20160048.

Tseng, Z. J. e Wang, X. (2011). Do convergent ecomorphs evolve through convergent morphological pathways? Cranial shape evolution in fossil hyaenids and borophagine canids (Carnivora, Mammalia). Paleobiology, 37(3):470-489. 
Tucker, M. A., Ord, T. J., e Rogers, T. L. (2016). Revisiting the cost of carnivory in mammals. Journal of Evolutionary Biology, 29(11):2181-2190.

van Heteren, A. H., MacLarnon, A., Soligo, C., e Rae, T. C. (2015). Functional morphology of the cave bear (Ursus spelaeus) mandible: a 3D geometric morphometric analysis. Organisms Diversity \& Evolution, 16(1):299-314.

Van Valkenburgh, B. (1985). Locomotor diversity within past and present guilds of large predatory mammals. Paleobiology, pgs. 406-428.

Van Valkenburgh, B. (1988). Trophic diversity in past and present guilds of large predatory mammals. Paleobiology, 14(2):155-173.

Van Valkenburgh, B., Pang, B., Bird, D., Curtis, A., Yee, K., Wysocki, C., e Craven, B. A. (2014). Respiratory and olfactory turbinals in feliform and caniform carnivorans: the influence of snout length. The Anatomical Record Part A: Discoveries in Molecular, Cellular, and Evolutionary Biology, 297(11):2065-2079.

Van Valkenburgh, B. e Wayne, R. K. (1994). Shape divergence associated with size convergence in sympatric East African jackals. Ecology(Durham), pgs. 1567-1581.

Wilson, D. E. e Reeder, D. M. (2005). Mammal species of the world: a taxonomic and geographic reference, volume 1. JHU Press.

Wroe, S. e Milne, N. (2007). Convergence and Remarkably Consistent Constraint in the Evolution of Carnivore Skull Shape. Evolution, 61(5):12511260.

Yonezawa, T., Kohno, N., e Hasegawa, M. (2009). The monophyletic origin of sea lions and fur seals (Carnivora; Otariidae) in the Southern Hemisphere. Gene, 441(1-2):89-99.

Zahn, T. M. G. (2016). Integração morfológica no crânio e evolução da morfologia craniana em Feliformia (Carnivora: Mammalia). Master's thesis. 
Capítulo 2

Materiais e Metodos 


\section{Amostragem}

\section{Coleções e esforço amostral}

O presente projeto se baseou inteiramente na disponibilidade de materiais osteológicos em coleções de museus de história natural e zoologia. O grupo Caniformes é um dos poucos táxons de mamíferos que está presente em todos os continentes do mundo, incluindo Antártica. Devido a sua ampla distribuição, coleções brasileiras e regionais não são o suficiente para amostrar o grupo de forma satisfatória. Sendo assim, o projeto necessitou da visita a diversas coleções da América do Norte e do Sul. Coleções da América do Sul foram escolhidas principalmente pela conveniência e baixo custo, enquanto coleções Norte-Americana foram visitadas pois apresentam acervos extensos representativos de diversas regiões do mundo.

No total foram visitadas 11 coleções, sendo elas: Museu de Zoologia da Universidade de São Paulo (MZUSP, São Paulo), Museu Nacional (MN, Rio de Janeiro), Museu Paraense Emilio Goeldi (MPEG, Belém), Museo Argentino de Ciencias Naturales Bernardino Rivadavia (MACN, Buenos Aires), Museo de La plata (FCNyM, La plata), American Museum of Natural History (AMNH, New York), National Museum of Natural History of the Smithsonian Institution (USNM, Washington), Museum of Comparative Zoology (MCZ, Harvard), Field Museum (FMNH, Chicago) e Academy of Natural Sciences of Drexel University (ANSP, Philadelphia). No total, foram gastos 2000 horas de esforço amostral, resultando em um total de 5626 espécimes amostrados de 166 espécies (Tabela 2.1). A lista completa de espécimes se encontra no Apêndice A. As amostras e a taxonomia utilizadas nos capítulos 3 e 4 podem ser encontrados nas tabelas D.1 e E.1, respectivamente. 
Tabela 2.1: Esforço amostral por instituição visitada. n- total de exemplares medidos. dias- total de dias úteis gastos na instituição. Esforço- total de horas gastas com amostragem. Horas/dia- Horas por dia gastas com a amostragem. $\mathrm{n} /$ hora- Espécimes medidos por hora. $\mathrm{n} /$ dia- espécimes medidos por dia. Valores "totais"são a soma para n, dias e esforço, e valores médios para horas/dia, n/hora e n/dia.

\begin{tabular}{llllllll}
\hline Instituição & Pais & $\mathrm{n}$ & dias & esforço $(\mathrm{h})$ & horas/dia & n/hora & n/dia \\
\hline MNRJ & BRA & 132 & 10.5 & 63 & 6 & 2.10 & 12.57 \\
MPEG & BRA & 112 & 10 & 60 & 6 & 1.87 & 11.20 \\
MZUSP & BRA & 327 & 43 & 172 & 4 & 1.90 & 7.60 \\
FCNyM & AR & 105 & 7 & 56 & 8 & 1.88 & 15.00 \\
MACN & AR & 236 & 13 & 104 & 8 & 2.27 & 18.15 \\
AMNH & EUA & 1123 & 61 & 366 & 6 & 3.07 & 18.41 \\
ANSP & EUA & 76 & 4 & 28 & 7 & 2.71 & 19.00 \\
FMNH & EUA & 684 & 22 & 176 & 8 & 3.89 & 31.09 \\
MCZ & EUA & 106 & 4 & 32 & 8 & 3.31 & 26.50 \\
MVZ & EUA & 1488 & 68 & 612 & 9 & 2.43 & 21.88 \\
USNM & EUA & 1230 & 41 & 328 & 8 & 3.75 & 30.00 \\
Outros* & BRA & 7 & 1 & 3 & 3 & 2.33 & 7.00 \\
total & & 5626 & 284.5 & 2000 & 6.75 & 2.63 & 18.20 \\
\hline
\end{tabular}

*- espécimes não-tombados de Canis familiaris de coleções veterinarias.

\section{Marcos anatômicos e medidas}

\section{Definição e identificação dos Marcos Anatômicos}

A escolhas de marcos anatômicos seguiu trabalhos prévios do nosso grupo (e.g.Cheverud, 1982, 1996; Ackermann e Cheverud, 2000; Cheverud et al., 1983; Marroig e Cheverud, 2001; Oliveira et al., 2009; Hubbe et al., 2016), principalmente as propostas de Porto et al. (2009). A configuração de marcos anatômicos do crânio de Caniformes pode ser vista na Figura 2.1. Todos os marcos anatômicos utilizados estão localizados nas suturas entre 3 ossos ou na extremidades de suturas (marcos anatômicos do tipo I e II, respectivamente sensu Bookstein, 1997).

Apesar dos marcos utilizados serem homólogos e presentes em todas as espécies analisadas, sua identificação não foi trivial em todos os casos. 
Isso se deve a dois fatores principais. Primeiro, Caniformes apresentam uma grande variabilidade no tempo de fechamento de suturas cranianas (Goswami et al., 2013), com famílias, como Mustelidae e Procyonidae, nas quais os ossos do crânio se fusionam completamente muito cedo na vida do animal e outros grupos, como Phocidae, no qual grande parte das suturas nunca se fecha. Segundo, em alguns grupos a anatomia e formas cranianas são extremamente variáveis, com mudanças radicais da posição de marcos anatômicos (ver descrição abaixo). Esse segundo fator por si só não seria problemático, mas em conjunto com o primeiro torna a identificação de marcos anatômicos com base em análises comparativas complicada.

Para contornar essas questões, inicialmente se avaliou um método que consiste na utilização de uma luz emitida através do côndilo occipital dos espécimes de forma a tornar as suturas mais visíveis. Entretanto em muitas espécies de maior porte, como no caso de Pinipedia, os ossos eram espessos demais para a luz atravessar. Adicionalmente, e mais preocupantemente, nos grupos mais fusionados - Musteloidea principalmente - esse método se mostrou impreciso. Isso foi verificado com a utilização de séries ontogenéticas disponíveis, nas quais foi observado que o padrão evidenciado pela iluminação representava mais a impressão das circunvoluções do cérebro do que o padrão de suturas ainda visíveis em indivíduos juvenis. Isso também foi observado em grupos nos quais as suturas estavam visíveis ao longo de quase toda a ontogenia, como Canidae. Sendo assim, a solução encontrada foi a utilização de séries ontogenéticas para diagnosticar a localização dos marcos anatômicos. Isso foi feito principalmente através de: (1) a observação da posição dos marcos nos juvenis; (2) a relação destes marcos com outras estruturas cranianas e; (3) sua modificação ao longo da série ontogenética, especialmente a manutenção de sua posição relativa nos diversos estágios de desenvolvimento. Foram utilizadas séries para a espécie sendo 


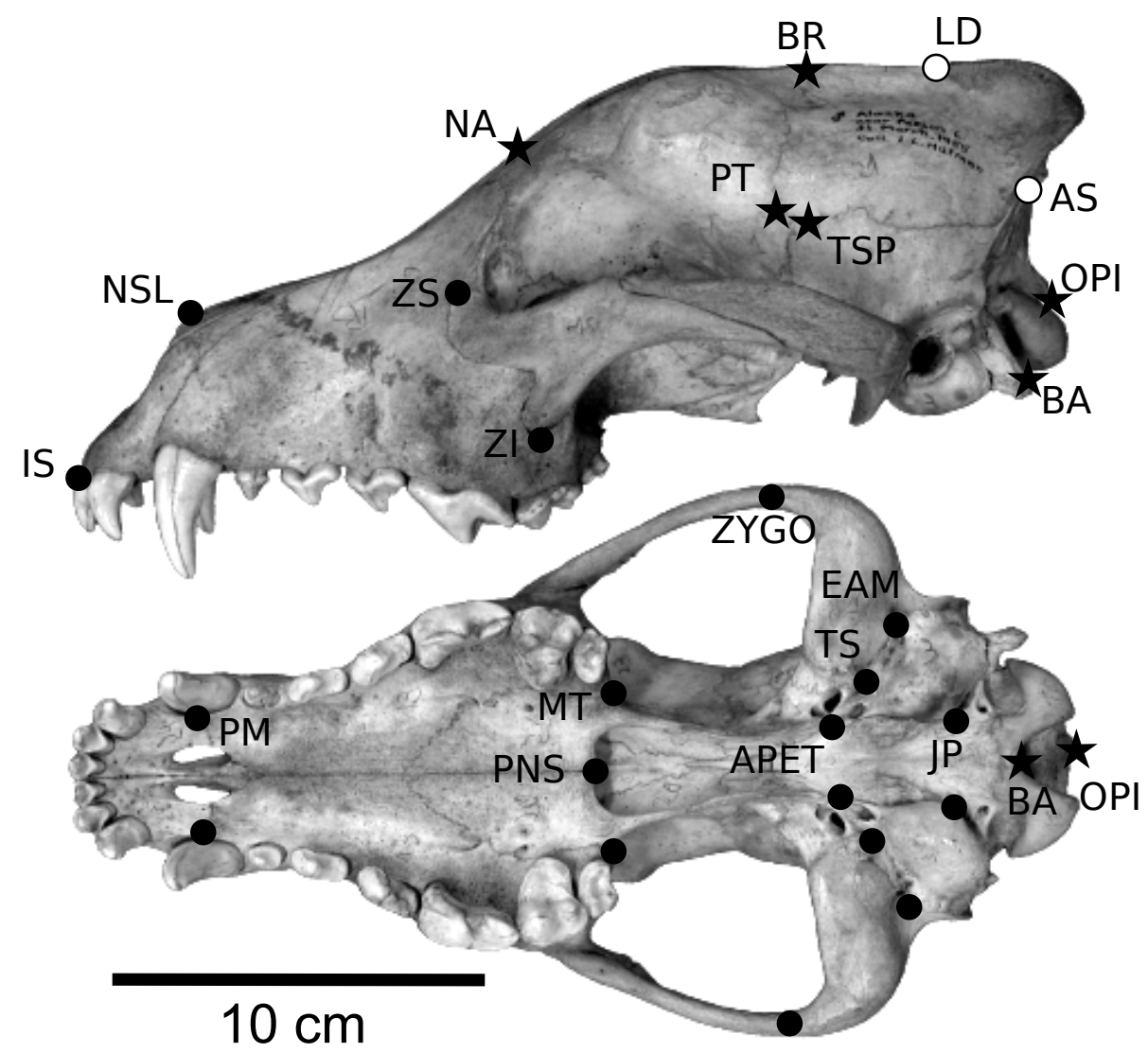

Figura 2.1: Marcos anatômicos em ambas as vistas digitalizadas sobre o crânio de um espécime de Canis lupus. Pontos negros e brancos representam marcos restritos às vistas $\mathrm{A}$ e $\mathrm{Z}$, respectivamente. Estrelas são pontos comuns a ambas as vistas.

medida ou, alternativamente, para espécies do mesmo gênero, quando as primeiras não estavam disponíveis. Essa metodologia possibilitou inferir a posição dos marcos anatômicos para todas as espécies de Caniformes.

Abaixo descrevo a anatomia dos marcos utilizados e comento brevemente sobre mudanças anatômicas que influenciaram no trabalho.

NSL - Sutura mais anterior entre ambos nasais. Em muitos indivíduos um dos ossos estava ausente ou deslocado. Foi comum observar, principalmente em canídeos e procionídeos, uma leve abertura de ambos os nasais, o que deslocaria o marco posteriormente. Em tais casos foi pos- 
sível observar a presença de ranhuras que indicavam o ponto de encontro entre os ossos, auxiliando o posicionamento preciso do marco.

NA - Sutura entre os ossos nasais e o frontal. Esse ponto é geralmente nãoambíguo e facilmente localizado em todos os grupos. Muitas vezes os nasais diferem em tamanho, principalmente em grupos com face mais alongada, como Canidae. Nesses casos escolhia-se o ponto mais posterior para demarcar o ponto.

PM - Ponto mais lateral da sutura premaxilar-maxilar em vista ventral. Em algumas espécies, a sutura entre a pré-maxila e a maxila estende-se a partir do plano médio do palato até a região interna (ou lingual) do dente canino. Quando isto ocorreu, PM foi registrado no encontro da sutura com o canino.

MT - Ponto mais posterior da sutura entre o palatino e maxila no palato ósseo. Trabalhos prévios definiram este ponto como sendo a ponta da tuberosidade da maxila (Porto et al., 2009). Entretanto, tal estrutura não está presente na maior parte dos táxons aquáticos e alguns terrestes, que apresentam um continuo entre a asa do pterigoide e a série dentaria. A sutura acima descrita está em associação próxima com a tuberosidade da maxila sempre que esta está presente. Assim, a sutura foi usada como uma aproximação do ponto para os taxons investigados.

IS - Ponto médio da maxila na porção inferior do septo entre os incisivos.

PNS - Ponto mais posterior da sutura entre os palatinos. Na maior parte das espécies isso também correspondeu ao ponto mais posterior do palato ósseo, exceto em Arctonyx (Mustelidae), na qual as asas do pterigoide se fusionam medialmente, formando uma extensão do palato ósseo. 
ZI - Ponto mais inferior e posterior da sutura zigomático-maxilar. Na maioria dos caniformes, a região anterior do zigomático faz uma curvatura característica, na qual uma porção pequena do maxilar contribui para a formação do arco. Isso descreve um desenho em "C"(que pode ser visto na Figura 2.1), que é comum a quase todos os Caniformes, exceto Phocidae. Nesse grupo, o maxilar avança muito mais posteriormente na região ventral do arco. Assim, a sutura inferior entre o maxilar e o zigomatico se encontra no meio do arco, e não no encontro deste com a região lateral do rostro. De qualquer forma, o ponto foi marcado nessa mesma sutura, na posição mais ventral, o que nem sempre correspondia à ponta da projeção da maxila (que podia se encontrar na lateral interna do arco, muitas vezes inacessível).

ZS - Ponto mais superior da sutura zigomático-maxilar. A posição anatômica desse marco variou bastante entre grupos. Enquanto em Ursidae e Canidae, por exemplo, o zigomático encontrava com a maxila na região lateral do rostro, em Phocidae e alguns Mustelidade a maxila contribui para a formação do arco, fazendo com que o marco fosse deslocado posteriormente.

ZYGO - Ponto mais posterior da sutura temporal-zigomático.

EAM - Ponto anterior do meato auditivo externo. No caso de alguns animais maiores (e.g. Ursidae, Otariidae), o canal auditivo se expande, formando um tubo alongado. Nesses casos o ponto foi marcado próximo à borda do canal auditivo, na região externa.

TS - Sutura temporal-esfenoidal-basioccipital. Em Phocidae, essa região encontravase extremamente modificada. $\mathrm{O}$ encontro entre os ossos ocorria no interior de uma fenestra, inacessível pelo equipamento. Nestes casos, 
marquei o ponto na sutura entre o temporal e o basioccipital na altura da bula timpânica.

JP - Borda mais lateral e posterior do forame jugular, na sutura entre o basioccipital e o temporal. Porto et al. (2009) definiram este ponto como sendo na base do processo jugular, na sutura entre o basioccipital e o temporal. Porém em algumas espécies o processo julgal encontra-se distante desta sutura, e muitas vezes estremamente modificado, sendo de dificil detecção. Visto que a sutura entre o basioccipital e o temporal sempre se encontrava associada ao forame jugular, este ponto foi escolhido.

APET - Ponto anterior da crista petrosal. Essa crista pode ser frágil em muitos animais menores. No caso dessa estrutura estar quebrada em ambos os lados do crânio, o marco foi estimado como sendo o ponto mais anterior da depressão formada por essa crista no basicrânio.

BA e OPI - Lábio ventral e dorsal do forame magno, respectivamente. Nas espécies maiores o forame pode ser muito robusto, dificultando a identificação de um ponto específico para ambos marcos. A forma dos lábios podia variar também, desde achatado, com uma superficie variando desde reta até arredondada. Por essas peculiaridades, esses marcos foram sempre marcados ou na região mais extrema dos labios, ou no ponto médio (quando os labios apresentavam um achatamento).

AS - Sutura occipital-parietal-temporal. Apesar de ser precisamente definido, o ponto varia consideravelmente de posição entre diferentes grupos. O motivo disso é que o temporal apresenta dois componentes referentes à região esquamosal e ao petromastóide. Em grupos que apresentam a caixa craniana expandida (e.g. Mustelidae, Phocidae, Odobenidae), ambas partes são indiferenciáveis, enquanto em grupos com 
caixa craniana menos alongada (e.g. Ursidae, Canidae) a região petromastóide se encontra bastante reduzida no sentido antero-posterior. Neste último caso o petromastóide varia muito de tamanho, principalmente no sentido dorso-ventral, algo particularmente evidente em Canidae. Adicionalmente, na maioria das espécies de lontras (Lutreolinae), o parietal sofre uma modificação extrema, dominando a caixa craniana, se estendendo até a região ventral do crânio. Essa extensão do parietal era acompanhada pele redução da região petromastoide no sentido dorso-ventral fazendo com que o ponto AS fosse registrado na região ventral do cranio, próximo ao ponto JP. Sendo assim, apesar da definição do marco se manter a mesma em todo grupo, a posição relativa do marco variou bastante entre grupos.

LD - Sutura entre os parietais e interparietais. Visto que o interparietal assume diversas formas ao longo da evolução dos mamíferos (Koyabu et al., 2012), esse ponto pode se encontrar em regiões muito diferentes do crânio. Em Canidae e Ursidae, por exemplo, o interparietal avança por entre os parietais pela região dorsal do crânio. Em Otariidae e em Mustelidae, o interparietal forma um contínuo com o supra-occipital (Koyabu et al., 2012), sendo que o LD fica definido como o ponto mais posterior e dorsal do crânio. Isso não traz problemas para a definição do marco, mas pode ter implicações para a interpretação das distâncias baseadas neste ponto.

BR - Sutura entre os frontais e parietais. Algumas espécies podem apresentar uma crista sagital pronunciada que pode influenciar na medição do ponto. Via de regra, quando a crista é pouco pronunciada o ponto foi marcado no topo da crista. Porém em espécies de crista muito pronunciada, como Otaria flavescens, o ponto foi marcado nas laterais da 
crista, próximo à base, sobre a sutura entre o frontal e o parietal.

PT e TSP - Sutura frontal-parietal-esfenóide e temporal-esfenóide-parietal, respectivamente. Esses pontos se mostraram consideravelmente variáveis ao longo de todos os grupos, com muitos casos onde não era possível distingui-los por haver um único ponto de encontro entre frontaltemporal-parietal-esfenóide. Adicionalmente, em alguns casos, existem projeções ventrais e posteriores do frontal, formando uma nova sutura estendida entre o frontal e o temporal, dando a impressão de que ambos os pontos se "inverteram"no sentido antero-posterior. Nesses casos o TSP foi marcado como sendo o encontro entre temporalfrontal-esfenóide e o PT como o encontro do frontal-parietal-temporal. Em Phocidae, esses pontos podiam encontrar-se deslocado ventralmente, principalmente em especies com o encéfalo mais expandido, como Mirounga, Pusa e Phoca.

\section{Digitalização dos espécimes}

As medidas morfométricas foram obtidas através da digitalização de marcos anatômicos no crânio dos espécimes. A digitalização dos marcos se deu com a ajuda de um sistema Microscribe MLX (Immersion Corporation - San Jose, California) que permite o registro de coordenadas tri-dimensionais ( $\mathrm{Fi}$ gura 2.2A). Os espécimes foram fixados em massa de modelar não-orgânica em duas posições distintas, chamadas de vista A e Z (Figura2.2B-C e 2.1). A vista A apresenta 25 marcos, dos quais 7 se encontram na linha média do crânio e 18 são bilaterais (9 pares). A vista $Z$ apresenta 11 marcos, dos quais 7 são da linha média e 4 são bilaterais (2 pares). A massa utilizada teve que ser resistente o suficiente para manter o espécime na sua posição, mas não tão resistente que impedisse ser modelada com facilidade. Dada a grande 
variação de tamanho e de forma em Caniformes, diferentes materiais tiveram que ser utilizados, dependendo sempre do tamanho e da resistência dos espécimes medidos e as condições ambientais da área de trabalho. Isso se deve ao fato de que massas de modelar respondem à temperatura, se tornando mais resistentes em ambientes mais frios e mais macias em ambientes mais quentes. Se a massa era macia demais, ela podia não proporcionar sustentação adequada, além de soltar partes, principalmente dentro de suturas, o que pode eventualmente danificar espécimes de coleções. Nos casos em que isso ocorreu, instrumentos cirúrgicos e de dentista foram utilizados para limpar o espécime. Adicionalmente, no caso de animais de grande porte, como Mironga, Odobenus e Hydrurga, sacos de areia (ou outros objetos pesados) foram utilizados como apoio adicional, uma vez que a quantidade de massa era insuficiente para mantê-los imóveis.

As três coordenadas espaciais de cada marco foram então registradas (digitalizadas) em uma planilha de Microsoft Excel com a utilização de um software próprio do equipamento (Figura 2.3). Antes da digitalização de cada espécime, suas informações - como sexo, localidade, subespécie, identificador, coletor e etc - foram registradas (Figura 2.3A). A calibração do equipamento foi verificada antes de cada seção de digitalização pela medição de uma distância conhecida em uma régua (Figura 2.3D). Se a diferença estava acima da especificada pelo fabricante, o equipamento era recalibrado segundo o manual do fabricante.

Cada espécime foi medido duas vezes, o que ajudou a minimizar possíveis erros de medição (Figura 2.3B). Durante o processo de digitalização dos espécimes, distâncias fixas foram escolhidas para averiguar a precisão de cada ponto (Figura 2.3C). Se as distâncias ultrapassavam em muito o erro do equipamento, o individuo era medido novamente. Se diferenças persistissem, o equipamento era recalibrado. Aqui eu utilizei distâncias arbitrárias 
que não correspondiam necessariamente às distâncias que de fato foram utilizadas nas análises. Isso foi feito para não inflar artificialmente a precisão das medidas que foram de fato incorporadas nas análises.

Após a medição todos os espécimes foram fotografados com uma câmera Cannon EOS Rebel T3i nas vistas dorsal, lateral e ventral, com auxílio de um tripé ou estativa. A mandíbula dos espécimes, quando disponível, foi fotografada em vista lateral de ambos os lados, alinhando os dois maiores planos da estrutura com o plano da imagem. Todas as fotos foram tiradas com uma escala. Para minimizar os efeitos de paralaxe, a câmera foi colocada o mais distante possível do espécime e este foi colocado ao centro da imagem.

\section{Unificação das vistas}

A principio, todas as medidas podem ser obtidas nas configurações de marcos referentes a vista $\mathrm{A}$ e $\mathrm{Z}$ isoladamante. Entretanto, devido à diferenças na anatomia dos grupos, alguns marcos não puderão ser acessado pelas vistas convencionais para alguns grupos, como foi o caso dos marcos PT para Phocidae e AS para Lutreolinae (ver acima). Nesses casos, visto que existiam marcos anatômicos comuns a ambas as vistas, fez-se um procedimento de unificação das vistas para a obtenção de uma configuração completa na qual todas as medidas podiam ser tomadas.

Para cada réplica de cada espécime a unificação das vistas foi feita através da obtenção da matriz de rotação $\mathbf{R}$ que melhor satisfizesse

$$
\mathbf{A}_{c}=\mathbf{Z}_{c} \mathbf{R}
$$

onde $\mathbf{A}_{c}$ e $\mathbf{Z}_{c}$ são as matrizes de marcos comuns em ambas as vistas. Estas matrizes estão centralizadas, isto é, suas coordenadas estão centralizadas no 


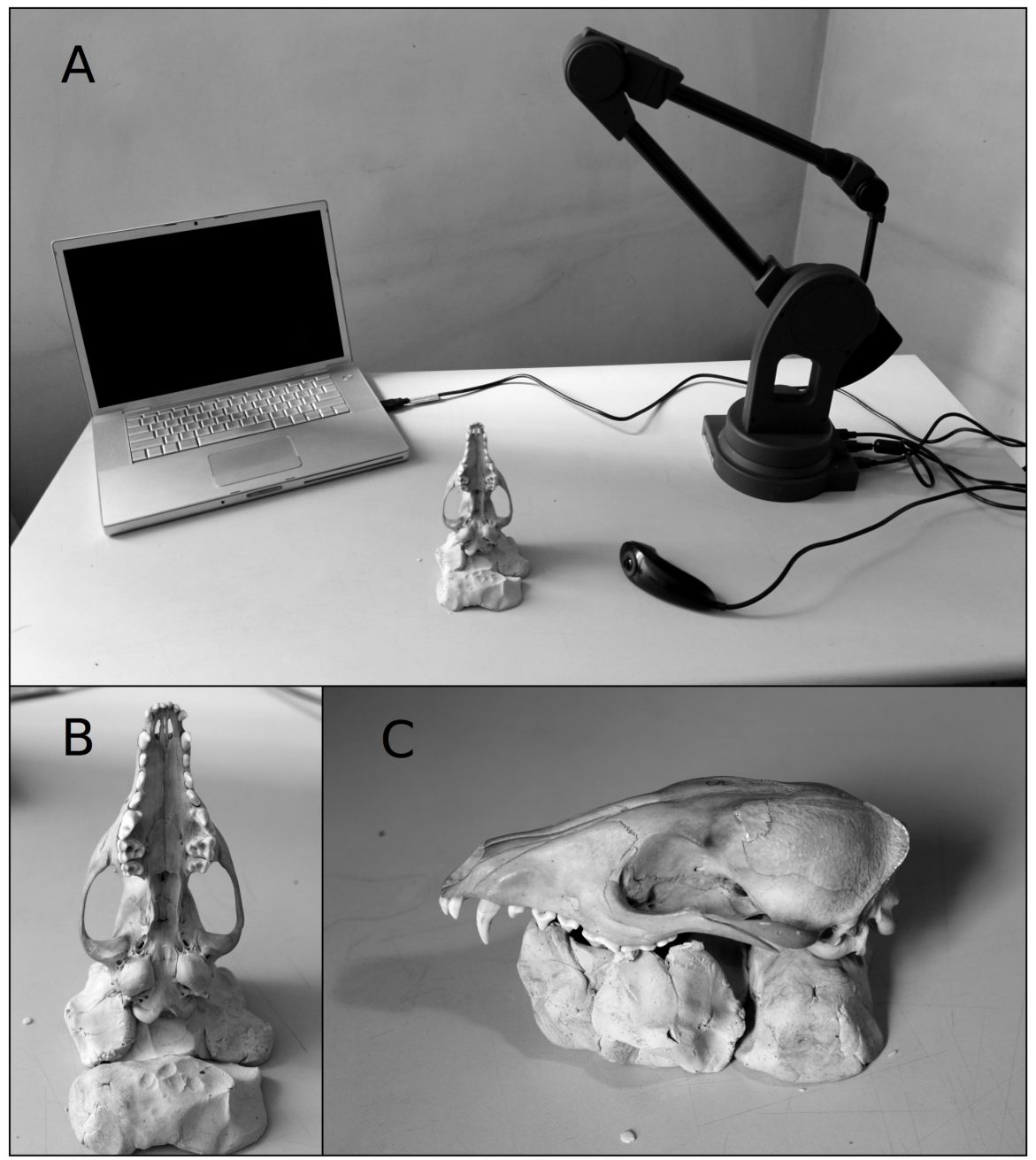

Figura 2.2: A- estação de trabalho para a digitalização dos crânios. B- Posição para a digitalização dos marcos anatômicos da vista A. C- Posição para a digitalização dos marcos anatômicos da vista Z. Ver a Figura 2.1 para marcos referentes às diferentes vistas. 


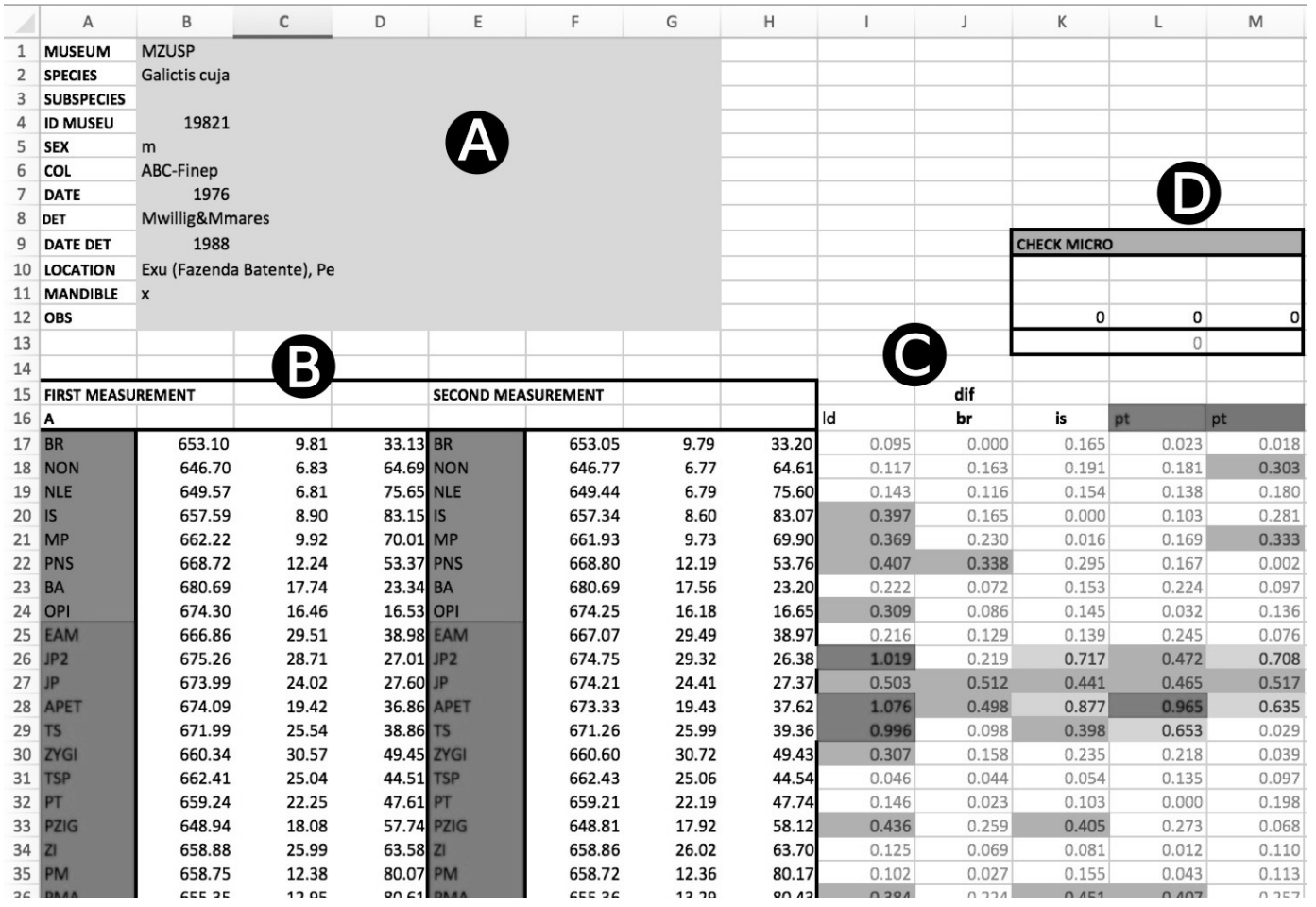

Figura 2.3: Planilha utilizada para a coleta de dados. A- Informações gerais sobre o espécimes sendo medido. B- Duas réplicas das coordenadas tridimensionais dos marcos anatômicos. C- Diferenças entre algumas medidas selecionadas para averiguar diferenças entre as duas digitalizações. D- Local para a verificação da calibração do equipamento.

centróide das configurações. Segundo (Schönemann, 1966), a matriz de rotação $\mathbf{R}$ que minimiza a soma dos quadrados das distâncias entre os marcos é dada por

$$
\mathbf{R}=\mathbf{V D}^{*} \mathbf{U}
$$

na qual V, U e D (sendo essa última utilizada para produzir $\mathbf{D}^{*}$ ) são obtidas através da decomposição de valor-singular da matriz $\mathbf{A}_{c}^{t} \mathbf{Z}_{c}$

$$
\mathbf{A}_{c}^{t} \mathbf{Z}_{c}=\mathbf{U D V}
$$

Os elementos $d_{i j}^{*}$ da matriz $\mathbf{D}^{*}$ são obtidos diretamente a partir dos ele- 
mentos $d_{i j}$ da matriz $\mathbf{D}$ da seguinte forma:

$$
d_{i j}^{*}=\left\{\begin{array}{cc}
d_{i j} /\left|d_{i j}\right|, & \text { se } i=j \\
0, & \text { se } i \neq j
\end{array}\right.
$$

As configurações de marcos finais foram obtidas como

$$
\mathbf{X}=\left[\begin{array}{c}
\mathbf{A}_{-c} \\
\mathbf{Z}^{*}
\end{array}\right]
$$

onde $\mathbf{A}_{-c}$ é a matriz de marcos de $\mathbf{A}$ sem os pontos comuns e $\mathbf{Z}^{*}=\mathbf{Z R}$. $\mathbf{A}_{-c}$ e $\mathbf{Z}$ encontram-se centralizadas nos marcos comuns.

\section{Medidas}

O conjunto de medidas utilizadas no presente trabalho (tabela 2.2) foi escolhido principalmente por três motivos. Primeiramente essas medidas buscam quantificar variações morfológicas restritas a um ou poucos ossos ou estruturas cranianas, permitindo assim a compreensão de processos ontogenéticos, genéticos ou funcionais localizados (Pearson e Davin, 1924; Cheverud, 1982). Secundariamente, essas medidas já foram extensivamente analisadas por nosso grupo (e.g.Cheverud, 1982, 1996; Ackermann e Cheverud, 2000; Cheverud et al., 1983; Marroig e Cheverud, 2001; Porto et al., 2009; Oliveira et al., 2009; Hubbe et al., 2016) o que permite a comparação direta dos resultados. Por último, análises de genética quantitativa desses caracteres tem apontado para a similaridade no padrão de covariâncias fenotípicas e genotípicas destes caracteres em grupos tão dispares quanto marsupiais (Porto et al., 2015), roedores (Garcia et al., 2014) e primatas (Cheverud, 1982; Marroig e Cheverud, 2010) tornando-os ideais para o tipo de análise realizado aqui. Os caracteres foram alocados nos módulos e regiões cranianas estabelecidas por Cheverud (1982), seguindo as sugestões de Porto et al. 
(2009).

As medidas foram obtidas calculando-se a distância linear entre um par de marcos anatômicos com a utilização do teorema de Pitágoras. Quando possível, medidas presentes em ambos os lados do crânio foram obtidas e a média de ambos valores foram usadas para representar a respectiva distância nas análises subsequentes. As medições foram tomadas para cada réplica medida, possibilitando assim obter dois conjuntos de medidas para cada espécime.

\section{Erro de medição}

Para estimar a confiabilidade das medições calculei a repetibilidade das medidas para espécies com 25 ou mais indivíduos (ver Capítulo 3). A repetibilidade pode ser definida como a porcentagem da variação total das medidas que pode ser atribuida às diferenças entre espécimes e que não está associada ao erro de medição intra-individual. A repetibilidade foi estimada como a proporção da variância total que pode ser explicada pelas réplicas segundo um modelo linear (Lessells e Boag, 1987).

As médias de repetibilidades foram sempre superiores a 0.91 quando avaliadas por espécies (Tabela 2.3) e superiores a 0.93 quando avaliadas por caráter (Tabela 2.4), com exceção de APET-TS (média=0.86) e BA-OPI (média=0.89), que também apresentaram os menores valores mínimos (BAOPI para Vulpes velox $=0.64$; APET-TS para Martes foina $=0.59$, Martes americana=0.60, Mustela altaica=0.59). Baixos valores de BA-OPI podem ser devido ao fato de que ambos pontos BA e OPI são marcos anatômicos do tipo II, o que dificulta identificação precisa do mesmo ponto em ambas as réplicas. Adicionalmente, a região do forame magno pode ser muito robusta, principalmente em espécimes maiores, o que dificulta mais ainda a medição 
Tabela 2.2: Medidas cranianas empregadas no presente estudo. As medidas são definidas por dois marcos anatômicos e são obtidas como a distância euclidiana entre eles. Ver figura 2.1 para localização dos marcos anatômicos.

\begin{tabular}{lll}
\hline Região & Modulo & Medida \\
\hline Face & Nasal & IS-NSL \\
Face & Nasal & NSL-NA \\
Face & Nasal & NSL-ZS \\
Face & Nasal & NA-PNS \\
Face & Oral/Nasal & IS-PNS \\
Face & Oral/Nasal & NSL-ZI \\
Face & Oral & IS-PM \\
Face & Oral & PM-ZS \\
Face & Oral & PM-ZI \\
Face & Oral & PM-MT \\
Face & Oral & ZI-MT \\
Face & Oral & MT-PNS \\
Face & Oral/Zigomático & ZS-ZI \\
Face & Zigomático & PT-ZYGO \\
Face & Zigomático & ZI-ZYGO \\
Face & Zigomático & ZI-TSP \\
Face & Zigomático & EAM-ZYGO \\
Face & Zigomático & ZYGO-TSP \\
Neurocrânio & Abóboda/Zigomático & PT-TSP \\
Neurocrânio & Abóboda & NA-BR \\
Neurocrânio & Abóboda & BR-PT \\
Neurocrânio & Abóboda & BR-APET \\
Neurocrânio & Abóboda & PT-APET \\
Neurocrânio & Abóboda & PT-BA \\
Neurocrânio & Abóboda & PT-EAM \\
Neurocrânio & Abóboda & LD-AS \\
Neurocrânio & Abóboda & BR-LD \\
Neurocrânio & Abóboda & OPI-LD \\
Neurocrânio & Abóboda & PT-AS \\
Neurocrânio & Abóboda & JP-AS \\
Neurocrânio & Base & PNS-APET \\
Neurocrânio & Base & APET-BA \\
Neurocrânio & Base & APET-TS \\
Neurocrânio & Base & BA-EAM \\
Neurocrânio & Base & BA-OPI \\
\hline & & \\
\hline & &
\end{tabular}


Tabela 2.3: Repetibilidade por espécie ( $\mathrm{n}>24$ )

\begin{tabular}{|c|c|c|c|c|c|c|c|}
\hline & Min. & Mean & Max. & & Min. & Mean & Max. \\
\hline Ailuropoda melanoleuca & 0.893 & 0.981 & 0.999 & Mellivora capensis & 0.861 & 0.984 & 1.000 \\
\hline Ailurus fulgens & 0.930 & 0.979 & 0.999 & Melogale moschata & 0.796 & 0.966 & 0.997 \\
\hline Aonyx cinerea & 0.856 & 0.973 & 0.998 & Melogale personata & 0.809 & 0.963 & 0.997 \\
\hline Arctocephalus australis & 0.944 & 0.994 & 1.000 & Melursus ursinus & 0.933 & 0.989 & 1.000 \\
\hline Arctocephalus gazella & 0.683 & 0.914 & 0.998 & Mephitis macroura & 0.870 & 0.963 & 0.998 \\
\hline Arctonyx collaris & 0.954 & 0.992 & 1.000 & Mephitis mephitis & 0.831 & 0.965 & 0.998 \\
\hline Atelocynus microtis & 0.893 & 0.981 & 0.998 & Mirounga angustirostris & 0.932 & 0.996 & 1.000 \\
\hline Bassaricyon alleni & 0.741 & 0.950 & 0.996 & Mirounga leonina & 0.988 & 0.998 & 1.000 \\
\hline Bassaricyon medius & 0.747 & 0.941 & 0.996 & Monachus tropicalis & 0.829 & 0.972 & 0.999 \\
\hline Bassariscus astutus & 0.612 & 0.920 & 0.994 & Mustela altaica & 0.590 & 0.956 & 0.999 \\
\hline Bassariscus sumichrasti & 0.724 & 0.962 & 0.998 & Mustela erminea & 0.712 & 0.951 & 0.997 \\
\hline Callorhinus ursinus & 0.891 & 0.988 & 1.000 & Mustela frenata & 0.802 & 0.969 & 0.999 \\
\hline Canis adustus & 0.814 & 0.980 & 0.999 & Mustela itatsi & 0.764 & 0.949 & 0.998 \\
\hline Canis aureus & 0.864 & 0.981 & 0.999 & Mustela kathiah & 0.842 & 0.967 & 0.998 \\
\hline Canis dingo & 0.896 & 0.988 & 1.000 & Mustela nigripes & 0.731 & 0.954 & 0.998 \\
\hline Canis familiaris & 0.884 & 0.983 & 1.000 & Mustela nivalis & 0.745 & 0.958 & 0.999 \\
\hline Canis latrans & 0.896 & 0.985 & 0.999 & Mustela putorius & 0.817 & 0.972 & 0.998 \\
\hline Canis lupus & 0.939 & 0.995 & 1.000 & Mustela sibirica & 0.810 & 0.965 & 0.997 \\
\hline Canis lycaon & 0.901 & 0.984 & 0.999 & Mustela vision & 0.851 & 0.969 & 0.999 \\
\hline Canis mesomelas & 0.807 & 0.976 & 0.997 & Nasua narica & 0.855 & 0.978 & 0.999 \\
\hline Canis rufus & 0.843 & 0.980 & 0.998 & Nasua nasua & 0.879 & 0.983 & 0.999 \\
\hline Cerdocyon thous & 0.891 & 0.978 & 0.999 & Nyctereutes procyonoides & 0.773 & 0.969 & 0.998 \\
\hline Chrysocyon brachyurus & 0.930 & 0.988 & 0.999 & Odobenus rosmarus & 0.907 & 0.983 & 1.000 \\
\hline Conepatus chinga & 0.925 & 0.983 & 0.999 & Otaria byronia & 0.972 & 0.996 & 1.000 \\
\hline Conepatus leuconotus & 0.868 & 0.956 & 0.996 & Otocyon megalotis & 0.868 & 0.976 & 0.999 \\
\hline Conepatus semistriatus & 0.877 & 0.979 & 0.998 & Pagophilus groenlandicus & 0.895 & 0.986 & 0.998 \\
\hline Cuon alpinus & 0.746 & 0.974 & 0.997 & Phoca hispida & 0.953 & 0.989 & 1.000 \\
\hline Cystophora cristata & 0.921 & 0.992 & 1.000 & Phoca vitulina & 0.837 & 0.990 & 1.000 \\
\hline Eira barbara & 0.829 & 0.977 & 0.999 & Poecilogale albinucha & 0.809 & 0.965 & 0.998 \\
\hline Enhydra lutris & 0.931 & 0.979 & 0.999 & Potos flavus & 0.878 & 0.971 & 0.998 \\
\hline Erignathus barbatus & 0.651 & 0.915 & 0.998 & Procyon cancrivorus & 0.873 & 0.979 & 0.999 \\
\hline Eumetopias jubatus & 0.953 & 0.995 & 1.000 & Procyon lotor & 0.873 & 0.979 & 0.999 \\
\hline Galictis cuja & 0.868 & 0.977 & 0.998 & Pteronura brasiliensis & 0.930 & 0.985 & 0.999 \\
\hline Galictis vitatta & 0.916 & 0.976 & 0.999 & Speothos venaticus & 0.881 & 0.980 & 0.998 \\
\hline Gulo gulo & 0.890 & 0.980 & 0.999 & Spilogale angustifrons & 0.593 & 0.926 & 0.996 \\
\hline Helarctos malayanus & 0.720 & 0.952 & 1.000 & Spilogale gracilis & 0.672 & 0.959 & 0.998 \\
\hline Ictonyx libyca & 0.789 & 0.946 & 0.998 & Spilogale putorius & 0.727 & 0.952 & 0.998 \\
\hline Ictonyx striatus & 0.863 & 0.961 & 0.998 & Taxidea taxus & 0.892 & 0.982 & 0.999 \\
\hline Leptonychotes weddelli & 0.775 & 0.948 & 0.995 & Tremarctos ornatus & 0.918 & 0.990 & 1.000 \\
\hline Lobodon carcinophaga & 0.933 & 0.990 & 0.999 & Urocyon cinereoargentus & 0.833 & 0.975 & 0.998 \\
\hline Lontra canadensis & 0.691 & 0.951 & 0.997 & Urocyon litoralis & 0.698 & 0.958 & 0.996 \\
\hline Lontra longicaudis & 0.775 & 0.976 & 0.999 & Ursus americanus & 0.973 & 0.996 & 1.000 \\
\hline Lutra lutra & 0.861 & 0.980 & 0.999 & Ursus arctos & 0.964 & 0.996 & 1.000 \\
\hline Lycalopex culpaeus & 0.851 & 0.982 & 0.998 & Ursus maritimus & 0.948 & 0.988 & 0.999 \\
\hline Lycalopex griseus & 0.855 & 0.980 & 0.998 & Ursus thibetanus & 0.915 & 0.985 & 0.999 \\
\hline Lycalopex gymnocercus & 0.883 & 0.980 & 0.998 & Vulpes chama & 0.804 & 0.974 & 0.998 \\
\hline Lycalopex sechurae & 0.844 & 0.969 & 0.997 & Vulpes lagopus & 0.801 & 0.972 & 0.997 \\
\hline Lycalopex vetulus & 0.778 & 0.964 & 0.997 & Vulpes macrotis & 0.826 & 0.975 & 0.998 \\
\hline Lycaon pictus & 0.865 & 0.979 & 0.998 & Vulpes ruppelli & 0.785 & 0.965 & 0.996 \\
\hline Martes americana & 0.598 & 0.958 & 0.997 & Vulpes velox & 0.635 & 0.936 & 0.995 \\
\hline Martes flavigula & 0.735 & 0.971 & 0.999 & Vulpes vulpes & 0.800 & 0.978 & 0.998 \\
\hline Martes foina & 0.592 & 0.938 & 0.997 & Vulpes zerda & 0.668 & 0.921 & 0.990 \\
\hline Martes pennanti & 0.727 & 0.980 & 0.999 & Zalophus californicus & 0.651 & 0.978 & 1.000 \\
\hline Martes zibellina & 0.732 & 0.944 & 0.996 & Zalophus wollebaeki & 0.924 & 0.990 & 0.999 \\
\hline Meles meles & 0.892 & 0.976 & 0.999 & & & & \\
\hline
\end{tabular}


Tabela 2.4: Repetibilidade por caráter

\begin{tabular}{rlllrlll}
\hline & Min. & Mean & Max. & & Min. & Mean & Max. \\
\hline APET-BA & 0.886 & 0.975 & 1.000 & OPI-LD & 0.832 & 0.963 & 0.999 \\
APET-TS & 0.590 & 0.861 & 0.988 & PM-MT & 0.824 & 0.976 & 1.000 \\
BA-EAM & 0.882 & 0.975 & 0.999 & PM-ZI & 0.841 & 0.979 & 1.000 \\
BA-OPI & 0.635 & 0.899 & 0.990 & PM-ZS & 0.856 & 0.976 & 1.000 \\
BR-APET & 0.720 & 0.985 & 1.000 & PNS-APET & 0.921 & 0.979 & 1.000 \\
BR-LD & 0.815 & 0.981 & 0.999 & PT-APET & 0.913 & 0.977 & 0.999 \\
BR-PT & 0.910 & 0.991 & 1.000 & PT-AS & 0.919 & 0.986 & 1.000 \\
EAM-ZYGO & 0.760 & 0.956 & 0.997 & PT-BA & 0.862 & 0.994 & 1.000 \\
IS-NSL & 0.844 & 0.974 & 1.000 & PT-EAM & 0.651 & 0.975 & 0.999 \\
IS-PM & 0.712 & 0.936 & 0.999 & PT-TSP & 0.892 & 0.984 & 0.999 \\
IS-PNS & 0.852 & 0.993 & 1.000 & PT-ZYGO & 0.683 & 0.987 & 1.000 \\
JP-AS & 0.651 & 0.923 & 0.995 & ZI-MT & 0.839 & 0.967 & 0.999 \\
LD-AS & 0.721 & 0.970 & 0.999 & ZI-TSP & 0.837 & 0.990 & 1.000 \\
MT-PNS & 0.727 & 0.961 & 0.999 & ZI-ZYGO & 0.747 & 0.977 & 1.000 \\
NSL-NA & 0.844 & 0.991 & 0.999 & ZS-ZI & 0.888 & 0.973 & 0.996 \\
NSL-ZI & 0.946 & 0.992 & 1.000 & ZYGO-TSP & 0.873 & 0.987 & 1.000 \\
NSL-ZS & 0.897 & 0.988 & 1.000 & ZI-PT & 1.000 & 1.000 & 1.000 \\
NA-BR & 0.919 & 0.995 & 1.000 & ZYGO-PT & 1.000 & 1.000 & 1.000 \\
NA-PNS & 0.798 & 0.992 & 1.000 & & & & \\
\hline
\end{tabular}

precisa do mesmo ponto repetidas vezes. No caso da distância APET-TS, as repetibilidades mais baixas provavelmente se devem ao fato de que em muitos casos a crista petrosal estava quebrada, sendo sua posição estimada pela presença de sulcos deixados pela estrutura. Curiosamente, nenhuma outra medida com o marco APET apresentou repetibilidades consideradas baixas, o que leva a crer que o tamanho diminuto desta medida também pode contribuir para esse padrão. A inclusão ou exclusão de ambas as medidas não alteraram os padrões gerais observados no Capítulo 3, e por isso foram mantidas em todas as análises. 


\section{Integração morfológica}

\section{Cálculo das matrizes}

Para espécies com 25 ou mais indivíduos amostrados obtive as matrizes de correlação e covariância entre os caracteres. Ao calcular tais matrizes, é importante identificar e controlar efeitos indesejados nas medidas, como variação geográfica e dimorfismo sexual. Para isso, testei o efeito destes fatores (sexo e subespécie e suas interações) através de Análises de Variância Univariada (ANOVAs) e Multivariada (MANOVA). Efeitos considerados relevantes foram removidos através de um modelo linear multivariado, e os resíduos desse modelo foram usados como dados para a estimativa das matrizes de covariância $V$ através da seguinte fórmula

$$
\mathbf{V}=\mathbf{D D}^{t} \frac{1}{d f}
$$

sendo $\mathrm{DD}^{t}$ a matriz dos produtos cruzados dos resíduos do modelo linear e $d f$ os graus de liberdade dos dados. No caso de espécies com o efeito de fatores controlados, $d f$ é igual aos graus de liberdade residuais do modelo linear. Isso é equivalente a multiplicar a matriz de covariância estimada por $(n-1) / d f$, corrigindo para a perda de graus de liberdade através do modelo linear. No caso de não haverem fatores para serem corrigidos, $\mathbf{D D}^{t}$ é apenas a matriz de produtos cruzados dos dados centralizados, e $d f=n-1$, que é equivalente à estimativa de matriz de covariância amostral. Ver tabela D.1 para os efeitos controlados e o número amostral por espécie.

A partir da matriz $\mathbf{V}$ estimada, a matriz de correlação $\mathbf{C}$ pode ser calcu- 
lada como

$$
\mathbf{C}=\mathbf{S}^{-1} \mathbf{V S}^{-1}
$$

com $\mathbf{S}$ sendo uma matriz diagonal preenchida com os desvios padrões das variáveis.

\section{Comparação de matrizes}

As matrizes de correlação e de covariância foram comparadas entre os diferentes táxons pelo método de random skewers ou RS (Cheverud e Marroig, 2007). Esse método consiste na criação de vetores aleatórios de mesmo tamanho que o número de caracteres sob investigação (35, no presente caso) e a multiplicação desses vetores pelas matrizes $V$ ou $C$ de duas espécies distintas, produzindo pares de vetores resposta (um para cada matriz comparada). A correlação entre esses vetores resposta é igual ao cosseno entre eles, e a média das correlações entre todos os vetores aleatoriamente gerados é tida como uma medida de similaridade entre essas matrizes. Valores mais próximos de 1 indicam maior similaridade estrutural entre as matrizes, enquanto valores mais próximos de 0 indicam que as matrizes são mais dissimilares.

O método RS pode ser interpretado diretamente dentro do contexto da teoria de genética quantitativa, onde os vetores gerados podem ser vistos como gradientes de seleção $(\beta)$ aleatórios aplicados nas matrizes de covariância genética $\mathrm{G}$, produzindo respostas evolutivas $\Delta z$, ou

$$
\Delta z=\mathbf{G} \beta
$$

(Lande, 1979). Visto que para o crânio de mamíferos a matriz G é suficientemente similar ao seu análogo fenotípico P (Porto et al., 2009), a comparação 
A.

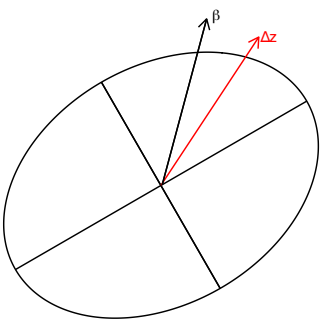

C.

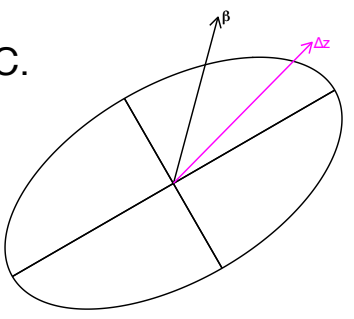

B.

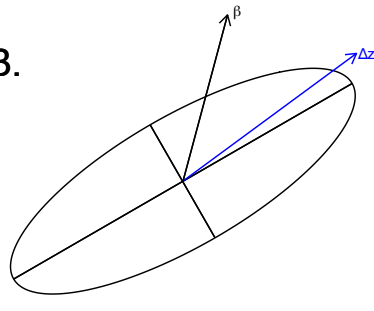

D.

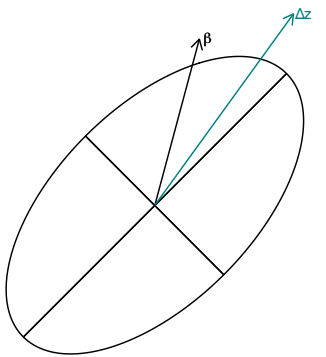

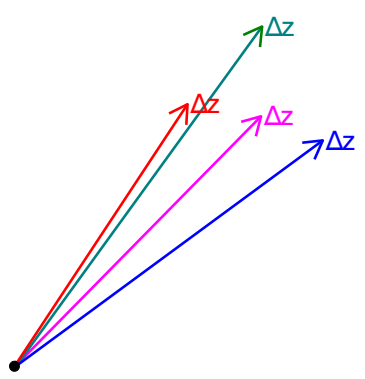

Figura 2.4: Representação esquemática do método de Random Skewers para um único gradiente de seleção $(\beta)$. No lado esquerdo- elipses correspondentes a matrizes de covariância para dois caracteres. Do lado direito- comparação direta das respostas $(\Delta z \mathrm{~s})$ provenientes de cada matriz. Cor indica indica a reposta $(\Delta z)$ produzida por cada matriz. Ver texto para descrição.

das matrizes fenotípicas através desse método pode ser interpretada como um teste da hipótese de que os táxons comparados respondem de forma similar à seleção natural (ver Capítulo 3).

A figura 2.4 exemplifica o RS para um único gradiente de seleção e diferentes matrizes $\mathbf{G}$ com dois caracteres. As matrizes A, B e C apresentam os mesmos componentes principais, porém com variância distribuídas de forma distintas: A apresenta variação distribuída mais homogeneamente entre seus dois PCs (i.e. menor correlação/integração entre caracteres); B apresenta o primeiro PC com mais variância que o segundo (i.e. maior correlação/integração entre caracteres); C é um caso intermediário entre A e B. D é equivalente a C porém levemente rotacionada, implicando que seus PCs são diferentes das outras matrizes. $\Delta z$ s de cores distintas são as respostas evolutivas de cada matriz ao mesmo gradiente de seleção $\beta$. Nesse exemplo é fácil de observar que, apesar da seleção ser a mesma em todos os casos, a resposta evolutiva varia bastante em função da geometria de G. 
A mudança na magnitude da integração/correlação entre os caractes afeta diretamente $\Delta z$ s, sendo que o angulo entre $\Delta z$ s reflete a diferença na esfericidade da matriz, com $\mathbf{C}$ sendo intermediária à $\mathbf{A}$ e $\mathbf{B}$. A mudança de padrão, como exemplificado na diferença entre $\mathbf{C}$ e $\mathbf{D}$ também modifica consideravelmente a resposta. É interessante notar que a resposta de $\mathbf{A}$ e $\mathbf{D}$ nesse exemplo em particular são muito similares, o que poderia nos fazer concluir que ambas matrizes são estruturalmente similares quando elas de fato não são. É por esse motivo que, para quantificar a similaridade das matrizes, é importante medir a correlação de vetores ao longo do máximo possível de dimensões. Isso é feito através da geração de um número grande de vetores aleatórios de forma a obter uma estimativa não enviesada de similaridade.

No próximo capítulo eu foco na comparação de matrizes de covariância empregando o RS. Apesar de outras medidas de similaridade e comparação de matrizes existirem, eu decidi restringir as análises a apenas RS por três principais motivos adicionais. Primeiro porque o RS em matrizes de covariância apresenta uma interpretação trivial dentro do contexto de genética quantitativa, como exposto em Cheverud e Marroig (2007). Segundo porque o RS apresenta uma extensão que permite investigar quais caracteres estão ligados às diferenças entre os grupos (Marroig et al., 2011). Em terceiro, uma comparação entre diferentes estatísticas empregadas em matrizes de covariância e correlação revelou que, mesmo quando diferentes métodos apresentam valores absolutos distintos (figura B.1) e correlações baixas entre si (tabela B.1), o principal padrão observado foi consistente entre as diferentes medidas (figuras B.2-B.5). Esta comparação se encontra no Apêndice B. Assim, a utilização de RS para análises de similaridade de matrizes é consistente com a avaliação de outras medidas de similaridade/dissimilaridade e permite um melhor entendimento dos padrões observados e clareza na exposição dos resultados. 


\section{Repetibilidade de matrizes}

Visto que covariâncias são estimativas, espera-se que elas não reflitam a estrutura de covariância populacionais, principalmente quando números amostrais são baixos (Cheverud, 1996; Marroig et al., 2012). A similaridade entre matrizes, então, deve levar em conta a capacidade daquele número amostral em recuperar estrutura de covariância populacional intraespecífica. Se uma amostra específica possui correlação abaixo de um $(0.8$, por exemplo) com outras matrizes obtidas de uma mesma população, então valores próximos à autocorrelação devem ser interpretados como indistintos empiricamente da matriz original, mesmo que tal valor seja diferente de 1. Segundo Cheverud (1996) uma estatística de similaridade $r_{o b s}$ entre matrizes pode ser ajustada da seguinte maneira

$$
r_{a d j}=\frac{r_{o b s}}{\sqrt{t_{1} t_{2}}}
$$

onde $t_{1}$ e $t_{2}$ são valores de repetibilidade (autocorrelação) de cada uma das duas matrizes comparadas. Logo, ao invés de comparar o valor bruto de similaridade contra um valor de 1.0 (total correlação/similaridade estrutural), a comparação é feita entre o valor observado e a média geométrica das repetibilidades das matrizes. A repetibilidade foi estimada usando um método de Monte Carlo (Marroig e Cheverud, 2001) onde a matriz de covariância é utilizada para gerar múltiplas amostras aleatórias. A partir destas amostras uma nova matriz de covariância ou correlação é obtida e comparada com a matriz original utilizando a estatística sendo avaliada (RS no presente caso). A média de similaridade entre todas as amostras e a matriz original é tida como a repetibilidade da matriz.

A figura 2.5 mostra as repetibilidades para todas as espécies com $n>5$ e evidencia a presença de um padrão bimodal, com um decréscimo constante 


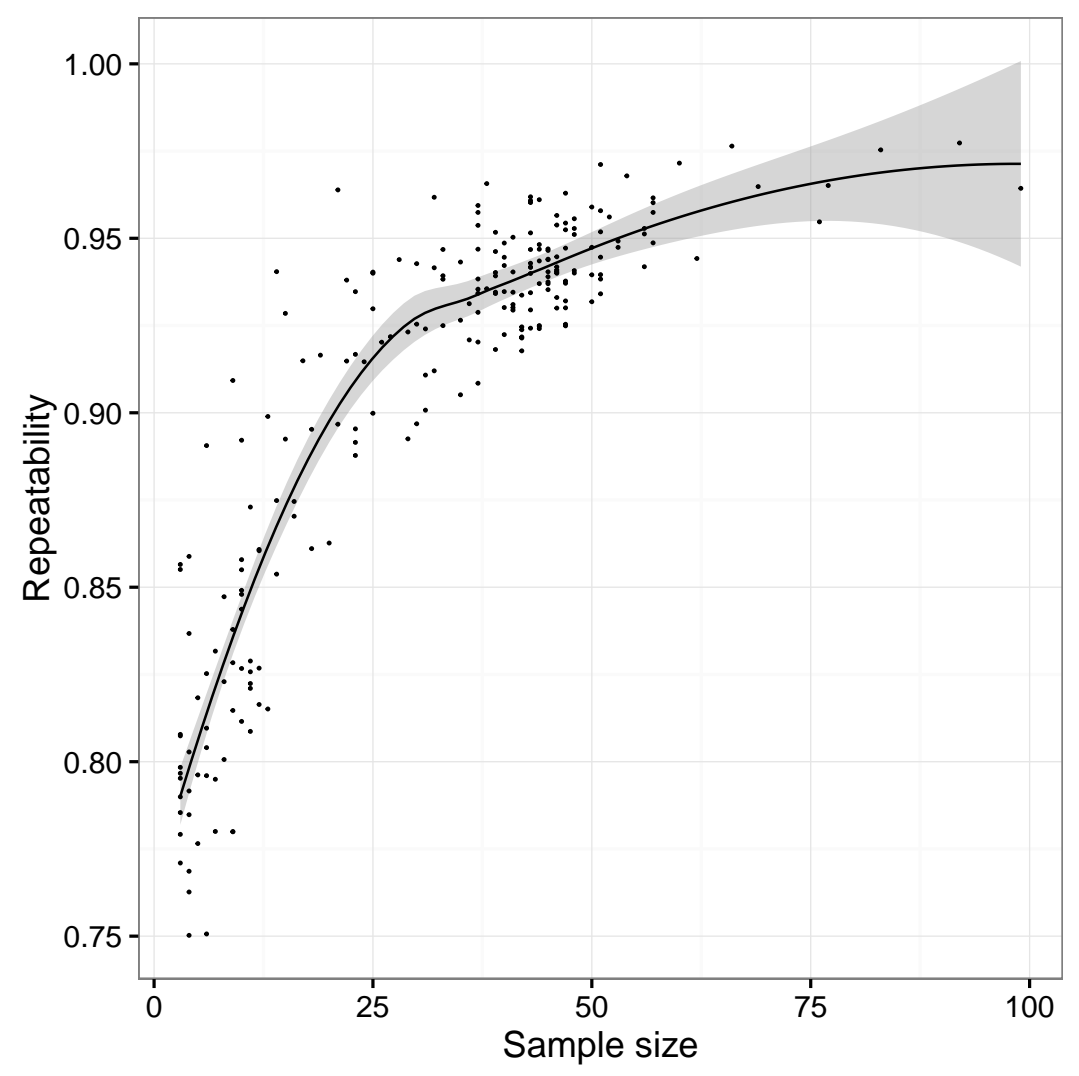

Figura 2.5: Repetibilidades empíricas estimadas para todas as espécies com $\mathrm{n}>5$. Linha escura é um ajuste do tipo loess. Polígonos cinza são os intervalos de confiança.

de repetibilidades para amostras entre 100-25 e uma redução mais abrupta para valores abaixo de 25. A maioria das amostras superiores a 25 apresentaram repetibilidades maiores que 0.9 , sugerindo que esse é um limite amostral confiável. 


\section{Referências Bibliográficas}

Ackermann, R. R. e Cheverud, J. M. (2000). Phenotypic covariance structure in tamarins(genus Saguinus): a comparison of variation patterns using matrix correlation and common principal component analysis. American Journal of Physical Anthropology, 111(4):489-501.

Bookstein, F. L. (1997). Morphometric tools for landmark data: geometry and biology. Cambridge University Press, Cambridge.

Cheverud, J. M. (1982). Phenotypic, genetic, and environmental morphological integration in the cranium. Evolution, 36(3):499-516.

Cheverud, J. M. (1996). Quantitative genetic analysis of cranial morphology in the cotton-top (Saguinus oedipus) and saddle-back (S. fuscicollis) tamarins. Journal of Evolutionary Biology, 9(1):5-42.

Cheverud, J. M. e Marroig, G. (2007). Comparing covariance matrices: random skewers method compared to the common principal components model. Genetics and Molecular Biology, 30:461-469.

Cheverud, J. M., Rutledge, J., e Atchley, W. (1983). Quantitative genetics of development: genetic correlations among age-specific trait values and the evolution of ontogeny. Evolution, 37(5):895-905.

Garcia, G. R. G., Hingst-Zaher, E., Cerqueira, R., e Marroig, G. (2014). Quantitative Genetics and Modularity in Cranial and Mandibular Morphology of Calomys expulsus. Evolutionary Biology, 41(4):619-636.

Goswami, A., Foley, L., e Weisbecker, V. (2013). Patterns and implications of extensive heterochrony in carnivoran cranial suture closure. Journal of Evolutionary Biology, 26(6):1294-1306.

Hubbe, A., Melo, D., e Marroig, G. (2016). A case study of extant and extinct Xenarthra cranium covariance structure: implications and applications to paleontology. Paleobiology, 42(3):465-488.

Koyabu, D. D., Maier, W. W., e Sánchez-Villagra, M. R. M. (2012). Paleontological and developmental evidence resolve the homology and dual embryonic origin of a mammalian skull bone, the interparietal. Proceedings of the National Academy of Sciences of the United States of America, 109(35):14075-14080.

Lande, R. (1979). Quantitative genetic analysis of multivariate evolution, applied to brain: body size allometry. Evolution, 33(1):402-416.

Lessells, C. M. e Boag, P. T. (1987). Unrepeatable repeatabilities: a common mistake. The Auk, (104):116-121. 
Marroig, G. e Cheverud, J. M. (2001). A comparison of phenotypic variation and covariation patterns and the role of phylogeny, ecology, and ontogeny during cranial evolution of New World monkeys. Evolution, 55(12):25762600.

Marroig, G. e Cheverud, J. M. (2010). Size As A Line Of Least Resistance II: Direct Selection On Size Or Correlated Response Due To Constraints? Evolution, 64(5):1470-1488.

Marroig, G., Melo, D., Porto, A., Sebastião, H., e Garcia, G. R. G. (2011). Selection Response Decomposition (SRD): A New Tool for Dissecting Differences and Similarities Between Matrices. Evolutionary Biology, 38(2):225241.

Marroig, G., Melo, D. A. R., e Garcia, G. R. G. (2012). Modularity, noise, and natural selection. Evolution, 66(5):1506-1524.

Oliveira, F. B. d., Porto, A., e Marroig, G. (2009). Covariance structure in the skull of Catarrhini: a case of pattern stasis and magnitude evolution. Journal of Human Evolution, 56(4):417-430.

Pearson, K. e Davin, A. G. (1924). On the biometric constants of the human skull. Biometrika, 16(3/4):328-363.

Porto, A., Oliveira, F. B. d., Shirai, L. T., Conto, V., e Marroig, G. (2009). The Evolution of Modularity in the Mammalian Skull I: Morphological Integration Patterns and Magnitudes. Evolutionary Biology, 36(1):118-135.

Porto, A., Sebastião, H., Pavan, S. E., VandeBerg, J. L., Marroig, G., e Cheverud, J. M. (2015). Rate of evolutionary change in cranial morphology of the marsupial genus Monodelphisis constrained by the availability of additive genetic variation. Journal of Evolutionary Biology, 28(4):973-985.

Schönemann, P. (1966). A generalized solution of the orthogonal procrustes problem. Psychometrika, 31(1):1-10. 

Chapter 3

Morphological Integration in the skull of Carnivora (Mammalia): Interplay between modularity, flexibility, patterns and magnitude 


\section{Introduction} 27 1996).
"Every organized individual forms an entire system of its own, all the parts of which naturally correspond, and concur to produce a certain definite purpose, by reciprocal reaction, or by combining towards the same end. Hence none of these separate parts can change their forms without a corresponding change in the other parts of the same animal, and consequently each of these parts, taken separately, indicates all the other parts to which it has belonged" -Georges Cuvier 1827, p. 90

Morphological integration refers to the fact that different phenotypic traits of organism are not fully independent from each other, and tend to covary in different degrees (Olson and Miller, 1958). This pattern has long been noticed by students of anatomy such as Georges Cuvier, the father of paleontology, who recognized not only that parts were contingently associated with each other but that they had to be, in order for organisms to perform their specific functions (Cuvier and Jameson, 1827). Although Cuvier concluded that integration (and its association with functional demands) was an impediment to the transmutation of species, Darwin argued that correlations among traits should be understood as "laws of variation" arising from correlations of ontogenetic growth (Darwin, 1859). In his view, integration is a constraint on the generation of variants, but not an absolute one, given that natural selection could ultimately overcome it in order to fine tune an species to its environment. Thus, the understanding of how populational variation is generated and how it interacts with natural selection in order to produce adaptations is a key component of evolutionary investigations (Lande, 1979; Lande and Arnold, 1983; Hansen and Martins, 
Genetically speaking, covariation among traits is the product of pleiotropy and linkage disequilibrium (Falconer et al., 1996; Lynch et al., 1998; Hansen, 2006). The covariation that arises from these factors influence not only how tightly related traits are in a population, but mainly how they will be inherited jointly (Hallgrímsson et al., 2009). This is especially important in the context of the study of natural selection because, in the presence of genetic covariances, selection on a character can indirectly influence the evolutionary response on another character.

According to the multivariate breeder's equation (Lande, 1979), the change in mean multivariate phenotype from one generation to the other will be

$$
\Delta \mathbf{z}=\mathrm{G} \beta
$$

38 where $\Delta \mathbf{z}=\left\{\Delta z_{1}, \Delta z_{2}, \ldots \Delta z_{n}\right\}$ is a column vector of mean changes on $n$ 39 traits; $\mathrm{G}$ is the $n x n$ matrix of variance-covariance of additive genetic ef40 fects (e.g. elements $G_{i i}$ are the additive genetic variances of trait $i$ and ele${ }_{41}$ ments $G_{i j}$ are the additive genetic covariances between traits $i$ and $j$ ), and ${ }_{42} \beta=\left\{\beta_{1}, \beta_{2}, \ldots \beta_{n}\right\}$ is the column vector of selection gradients, or the selec43 tion on each character that is independent of the selection on others (Lande, 46 for each trait will be

$$
\begin{aligned}
\Delta z_{1} & =G_{11} \beta_{1}+G_{12} \beta_{2} \\
\Delta z_{2} & =G_{21} \beta_{1}+G_{22} \beta_{2}
\end{aligned}
$$

${ }_{47}$ Its easy to see that, in the presence of non-zero genetic covariances $\left(G_{12}=\right.$ ${ }_{48} G_{21} \neq 0$ ), the evolutionary response of a trait will not only be a function of 
genetic variance and direct selection, but also indirect selection and genetic covariance (Lande and Arnold, 1983; Agrawal and Stinchcombe, 2009; Marroig et al., 2011). This suggests that the investigation of species divergence (i.e. $\Delta \mathbf{z}$ ) alone can, at best, paint an incomplete picture of the evolutionary processes at work (see Grabowski, 2016; Savell et al., 2016 for some empirical examples).

In comparative analysis, one of the main goals is to investigate past selective regimes in order to explain the observed diversity of forms. In a quantitative genetic framework, this is done by retrospectively estimating $\beta$ s from inferred $\Delta$ zs (e.g. Ackermann and Cheverud, 2004; Marroig et al., 2004; Marroig and Cheverud, 2005, 2010; Martínez-Abadías et al., 2012; Marroig et al., 2012; Schroeder et al., 2014; Grabowski, 2016; Savell et al., 2016), which can be done by simply rearranging Equation (3.1) as

$$
\beta=\mathrm{G}^{-1} \Delta \mathrm{z}
$$

If $\mathbf{G}$ differs greatly between species, estimated $\beta$ s can be imprecise, leading to wrong conclusions about the evolutionary history of a group (Turelli, 1988). So, to evaluate how well quantitative genetic theory can be applied in a macroevolutionary context, a preliminary investigation of the similarity of the patterns of morphological integration expressed in $\mathbf{G}$ for different species is a necessary first step.

There are two main ways in which differences in morphological integration are usually investigated: the first is related to the patterns - how characters are interrelated- and the second is related to the magnitude how strong are the interactions among characters. Differences in pattern and magnitudes of integration can lead to modularity, i.e the fact that characteres from one set (module) tend to have stronger correlations with other elements from the same set than with characteres from other sets (Olson and 
Miller, 1958; Berg, 1960; Wagner et al., 2007; Klingenberg, 2008). Genetically speaking, modularity pertains to the fact that characters vary in their interconnections due to pleiotropic effects (Wagner et al., 2007). Changes in the underlying pleiotropic effects can then alter both the magnitude of correlations (via increase pleiotropy between traits, Pavlicev et al., 2008), and patterns of integration and modularity (via changes in patterns of pleiotropic effects, Melo and Marroig, 2015).

The mammalian skull is an ideal model for the study of morphological integration in a comparative context. It is a complex structure made by the sum of simpler discrete units, or bones, which combine to form a larger integrated whole. The overall number and position of bones in the skull is remarkably conserved within mammals (Schoch, 2006), allowing for a phylogenetically broader comparison of trait measurements (Pearson and Davin, 1924). Ontogenetically speaking, even though each bone can be developmentally individualized, general ontogenetic factors affect more than one structure, producing different degrees of morphological integration and modularity (Cheverud, 1982; Hall, 2005; Hallgrímsson et al., 2007, 2009). Lastly, the skull is an important morpho-functional complex, combining diverse organs and functions that play important roles in the species ecology and evolution (Cheverud, 1982).

Previous large scale investigations of the morphological integration of the skull in mammals have painted a coherent picture. While matrices from different species respond similarly to natural selection (Marroig and Cheverud, 2001; Oliveira et al., 2009; Shirai and Marroig, 2010a; Marroig and Cheverud, 2010; Hubbe et al., 2016; Haber, 2016), overall magnitudes of overall integration tends to vary widely between even closely related species (Marroig and Cheverud, 2001; Oliveira et al., 2009). Furthermore, modularity patterns seem conserved among the major mammalian clades (Goswami, 
2006a; Porto et al., 2009; Shirai and Marroig, 2010a; Porto et al., 2013), reinforcing the idea that ontogenetic pathways and genetic architecture have been relatively stable throughout mammalian evolution. However, despite this stability at large scales (Goswami, 2006a; Porto et al., 2009, 2013), analyses within mammalian orders sometimes highlights differences at some species or genus (Oliveira et al., 2009; Shirai and Marroig, 2010b; Hubbe et al., 2016) or even between families (Haber, 2016). Thus, even though we expect that morphological integration will generally be conserved at broader scales, the investigation of less inclusive clades can still lead to significant insight into the evolution of morphological integration.

The objective of the present contribution is to evaluate the stability (or not) of the patterns of morphological integration of the skull in Carnivoran mammals. Carnivores are one of the most species-rich clades of large Mammals, containing almost 300 extant species, being the only order that can be consider to have populated all continents on Earth, including Antarctica. Carnivora displays an impressive diversity of skull shape disparity (Radinsky, 1981a,b, 1982; Drake and Klingenberg, 2010) which is accompanied by an equally impressive diversity of feeding strategies, ecological specializations and morphological variation. For these reasons, the group is considered to be an ideal natural model for the study of adaptation in the macroevolutionary scale (Goswami, 2010), especially regarding skull shape evolution (e.g. Wroe and Milne, 2007; Christiansen, 2008; Figueirido et al., 2009; Jones and Goswami, 2009; Figueirido et al., 2010; Slater et al., 2009, 2010; Tseng and Wang, 2011; Figueirido et al., 2011b, 2013; Meloro et al., 2015; Tseng and Flynn, 2015; Jones et al., 2015).

The morphological integration the Carnivoran skull has been investigated previously in two main works which have shown that that patterns of integration can change as a function of ecological demands (Meiri et al., 
2005; Goswami, 2006b). While Meiri et al. (2005) evaluated cranial measurements directly (e.g. length, height), their main findings were related to variation and covariaton of teeth morphology (see also Dayan et al., 2002). Goswami (2006b) on the other hand explicitly evaluated morphological integration of the skull using geometric morphometrics, and found that, despite being very similar among groups, patterns of integration correlated with both phylogeny (suggesting a phylogenetically structured variation) and with diet at less inclusive taxa. These last findings were, however, based on reduced species (30 spp) and intraspecific (15-22 specimens) samples, and did not explicitly investigated what are the actual modifications on the patterns of integration and their possible evolutionary consequences.

Here we aim to further our knowledge of the evolution of morphological integration within Carnivora by using one of the most comprehensive datasets in an explicit quantitative genetics context. We combine matrix comparison and pattern recognition techniques in order to identify the presence of any differences in the morphological integration among groups. To describe the identified patterns we integrate modularity and quantitative genetics methods to dissect the differences and similarities among groups.

\section{Materials and Methods}

\section{Sample}

More than 8300 specimens were evaluated and measured from the following institutions: Museu de Zoologia da Universidade de São Paulo (MZUSP, São Paulo), Museu Nacional (MNRJ, Rio de Janeiro), Museu Paraense Emilio Goeldi (MPEG, Belém), Museo Argentino de Ciencias Naturales Bernardino Rivadavia (MACN, Buenos Aires), Museo de La plata (FCNyM, La plata), American Museum of Natural History (AMNH, New York), National Mu- 
seum of Natural History of the Smithsonian Institution (USNM, Washington), Museum of Comparative Zoology (MCZ, Harvard), Field Museum (FMNH, Chicago), Academy of Natural Sciences of Drexel University (ANSP, Philadelphia), Museum für Naturkunde (ZMB_Mam, Berlin), Naturhistorisches Museum Wien (NMW, Vienna), Muséum National d'Histoire Naturelle (MNHN, Paris), Zoologisches Forschungsmuseum Alexander Koenig (ZFMK, Bonn), Př́rodovědecké muzeum - Národní muzeum (NMP, Prague), University Museum of Zoology, Cambridge (UMZC, Cambridge - UK), Senckenberg Naturmuseum Frankfurt (SMF, Frankfurt am Main) and Naturalis Biodiversity Centre (Naturalis, Leiden). Caniforms were measured by FAM and Feliforms were measured by TMZ. Taxonomy followed recent phylogenetic studies (Arnold et al., 2010; Fulton and Strobeck, 2010; Slater et al., 2012; Agnarsson et al., 2010; Nyakatura and Bininda-Emonds, 2012).

We included only adult individuals in the analysis. Given the high taxonomic heterogeneity of the sample, different criteria to infer specimen adulthood were established. For most species, age was inferred mostly by the eruption of the teeth and the level of closure of the basioccipital synchondrosis. Given the high diversity of suture closure timing in carnivorans (Goswami et al., 2013), some taxa (e.g. Phocids) never show high (if any) levels of suture-closure, while others (e.g. Mustelids and Procyonids) show high degree of bone fusing very early in live. So, in addition to the aforementioned criteria, adulthood was also established comparatively by observation of the largest individuals and characteristics that they might posses. For example, all adult fissipeds show a smother bone surface than its sub-adults counterparts. For pinnipeds, adulthood was mainly established by size and shape comparisons and evaluation of tooth-wear. Young adult specimens were sampled in some taxa, especially within Feliforms and particularly for species with lower sample sizes. Given that the covariation pattern of the 
skull is expected to be similar among ontogenetic stages (Hubbe et al in prep), for these taxa age (adult/young adult) was included as a factor to be controlled for (see below). Also, due to the rarity of some taxa in the visited institutions, we included captive animals in the dataset. Those individuals were carefully evaluated before measurement, and any evident deformation was basis for exclusion. We prioritized animals with sufficient information in order to identify if: 1-they were wild-caught, and 2-how much time they spent in captivity. Those two criteria were used to minimize deformations in the skull that could arise from prolonged captivity (Hartstone-Rose et al., 2014). The effect of captivity was controlled in matrix estimation (see below).

The removal of juveniles, individuals with uncertain taxonomic affinities, outliers and species with insufficient samples produced a total of 6,793 specimens (4,442 Caniformes/2,351 Feliformes) from 144 species (94 Caniformes / 50 Feliformes) included in 81 genera (45 Caniformes / 31 Feliformes), representing 16 carnivoran families (with Prionodontidae being the only absent family). This is one of the largest and most comprehensive datasets for exploring intraspecific morphological integration in the skull of Carnivorans (Table D.1).

\section{Morphometrics and data processing}

The morphometric measurements were obtained through digitized anatomical landmarks of the skull (Figure C.1) with the aid of a Microscribe MLX system (Immersion Corporation - San Jose, California). Landmarking followed previous works from the research group (e.g.Cheverud, 1982, 1996b; Ackermann and Cheverud, 2000; Cheverud et al., 1983; Marroig and Cheverud, 2001; Porto et al., 2009; Oliveira et al., 2009; Hubbe et al., 2016, Figure C.1). Skulls were digitized in two views to allow for the sampling of the whole 
skull. To unify these views, both configurations were mean-centered on the common landmarks and rotated in order to minimize their squared distances (Schönemann, 1966). From the final configurations, we obtained a set of 35 interlandmark distances to describe the skull morphology, following Porto et al. (2009). The list of measurements can be found on Table 2.2. When measurements for both sides of the skull were available, bilaterally symmetrical measurements were averaged between sides, producing a set of 35 measurements. Each individual was measured twice and repeatability was estimated as the proportion of the total variance that can be explained by replicates on a linear model (Lessells and Boag, 1987). All measurements were averaged between replicates for further analysis.

Outliers identification and normality inspection were done using graphical methods (Zuur et al., 2010) with both univariate and multivariate techniques. For the univariate case, we produced Quantile-Quantile plots (QQplots) for individual measurements for each species. QQ-Plots confront empirical quantiles and theoretical ones (from a normal distribution in this case) and help evaluate departures from normality and identify possible outliers in the sample. For the multivariate case, the squared Mahalanobis distance between each individual and the sample mean was estimated and plotted against the theoretical quantile from a Qui-squared distribution (Filzmoser et al., 2005). These methods were used along with other diagnostic methods (e.g. histograms and dotplots) to help identify and remove measurements or individuals from the dataset. Complementarily we performed multiple Lilliefors test for normality on each variable from each species. These procedures were performed on raw data and on the residuals of the linear model, after controlling for unwanted factors (see below). Together with the graphical results this suggests that there are no notable deviations from normality in this dataset. 


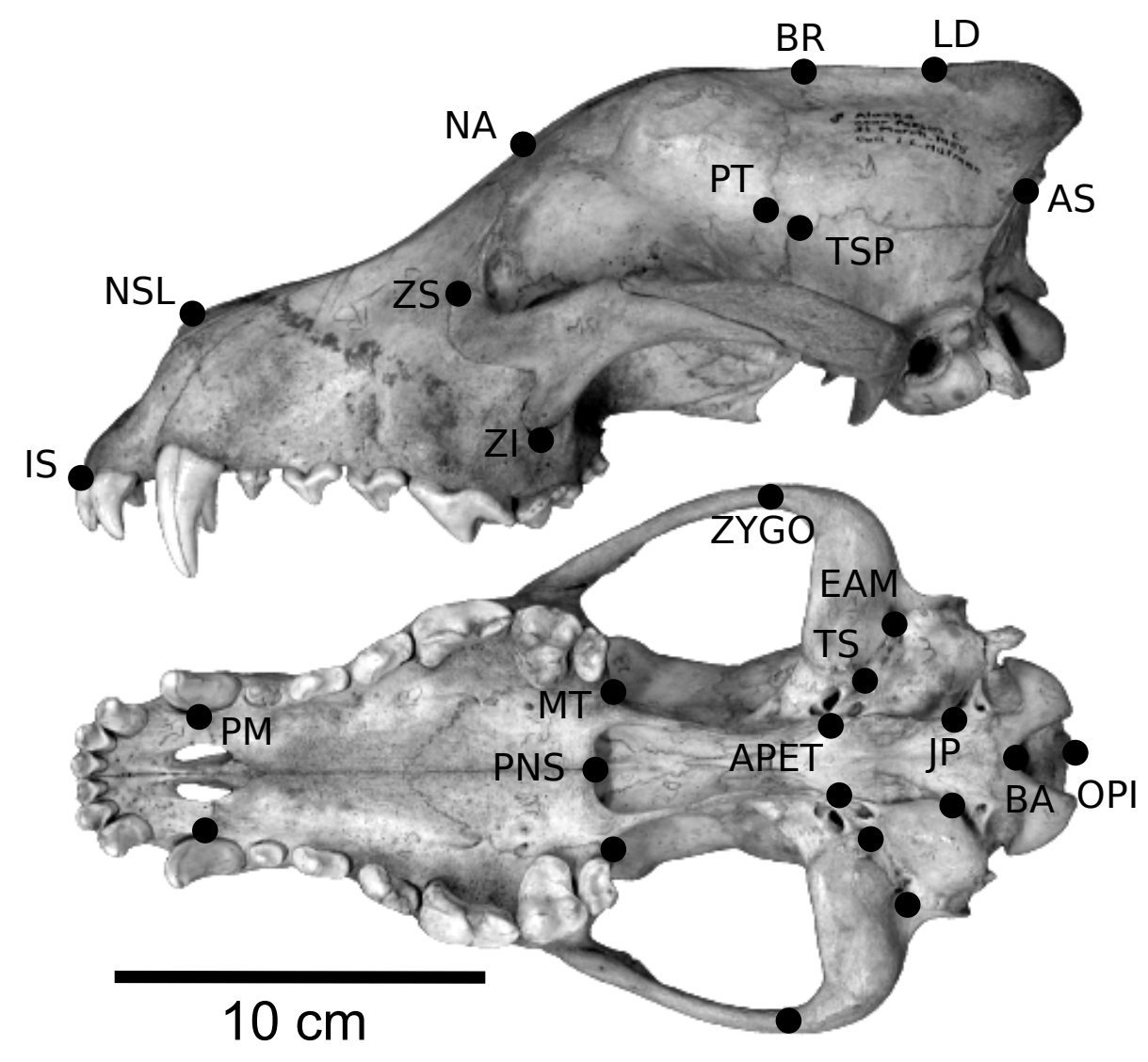

Figure 3.1: Landmarks shown on a Canis lupus skull. 
In the present work we chose to focus on the use of the classically measurements set of measurements used by our group instead of focusing on geometric morphometrics techniques. There are some known issues with the estimation of covariances of Procrustes-superimposed landmarks (Zelditch et al., 2012; Linde and Houle, 2009; Walker, 2000; Torcida et al., 2013) and of measures of repeatability (von Cramon-Taubadel et al., 2007) that could potentially affect our interpretations (see Garcia et al., 2015 for more details). Furthermore, these measurements are originally chosen in order to reflect specific dimensions of skull bones and structures in order to allow for a localized understanding of ontogenetic, genetic and functional processes (Cheverud, 1982; Pearson and Davin, 1924). While in classical morphometrics it is possible to alternate between a collection of traits and a single trait without losing equivalency -every column of a multivariate dataset is a meaningful trait on it own- the same cannot be said for geometric morphometrics, where each column (a coordinate of a landmarks) of the multivariate dataset only has meaning in relationship to other columns (other coordinates of the same landmarks and other landmarks through Procrustes superposition). Given that some of the techniques used here depends heavily on the capacity to bisect the phenotype (Marroig et al., 2011), the use of measurements, and not superimposed landmark configurations, is considered more adequate. Lastly, the quantitative genetics of these measurements has been extensively studied and the similarity between genotipic and phenotipic covariation patterns have been well established for multiple taxa (Porto et al., 2009; Garcia et al., 2014; Porto et al., 2015; Marroig and Cheverud, 2010). Because of these reasons, this set of measurements and choice of methodology are best suited to the objectives of the present investigation. 


\section{${ }_{267}$ The Cheverud Conjecture}

Obtaining accurate estimates of $\mathbf{G}$ can be problematic for most non-model organisms, as is the case for most mammalian species. This is because genetic variance and covariance have to be estimated through experimental breeding of large colonies (Steppan et al., 2002; McGuigan, 2006). While this can be achieved for some species in a laboratory setting (e.g. Cheverud, 1982; Cheverud et al., 1983; Lofsvold, 1986, 1988; Atchley and Zhu, 1997; Klingenberg and Leamy, 2001; Klingenberg, 2003; Wagner et al., 2008; Hlusko and Mahaney, 2009, and for rare exceptions in the wild (e.g. Wilson et al., 2007; Poissant et al., 2008; Martínez-Abadías et al., 2009), for most mammals reasonable direct estimates of $\mathbf{G}$ are highly unlikely. Phenotipic estimates of covariance (or $\mathbf{P}$ matrices) are, on the other hand, far easier to obtain. They can be estimated without information regarding genealogy and are (usually) better estimated, because sample sizes of $\mathbf{G}$ are based on the number of families, rather then individuals (Cheverud, 1988). Additionally, there is a wealth of evidence suggesting that phenotypic estimates of covariance largely reflects the underlying geometry of $\mathbf{G}$, particularly for morphological characters (Cheverud, 1988, 1996b; Roff, 1995; House and Simmons, 2005; Porto et al., 2009; Marroig and Cheverud, 2010; Garcia et al., 2014; Porto et al., 2015), thus allowing for the use of $\mathbf{P}$ as a surrogate of $\mathbf{G}$. This idea, sometimes called "The Cheverud Conjecture" (Cheverud, 1988), has been widely used on macroevolutionary studies (e.g. Ackermann and Cheverud, 2004; Marroig et al., 2004; Revell, 2007; Revell et al., 2010; Marroig and Cheverud, 2010; Schroeder et al., 2014; Grabowski, 2016; Savell et al., 2016).

The direct comparison of Ps on a broad phylogenetic context can also be used itself as evidence in support of Cheverud's conjecture. This is because $\mathbf{P}=\mathbf{G}+\mathbf{E}$, where $\mathbf{E}$ is a matrix of environmental (or residual) covariances. If 
we observe high similarities between Ps, than that either means that the underlying Gs are different and Es somehow compensate for these differences, or that both Gs and Es are similar among groups. Cheverud (1988) argued that, based on the prevalence of phenocopies in morphological characteres (envirormental perturbations that mimic mutations or genetic variantion), the last interpretation is more plausible, a fact that would also explains the similarity found for the Ps and Gs in different datasets. So, if we observe that $\mathbf{P}$ matrices are similar among species, we can conclude that the underlying Gs are stable, and that $\mathbf{P}$ and $\mathbf{G}$ for each species are structurally similar (Marroig and Cheverud, 2001). Therefore, the observation of a high similarity among Ps can give us not only information about the genetic architecture of individual species or groups, but also the validity of the extension of quantitative genetics theory into a macroevolutionary context.

\section{Covariance Matrix estimation}

Carnivorans are known to show intraspecific variation in skull morphology due to a myriad of factors. For example Cerdocyon thous, a middlesized South-American canid, shows considerable variation in size (Martinez et al., 2013) and shape (Machado and Hingst-Zaher, 2009) along its geographic range, a variation that coincides with classically described subspecies (Machado and Hingst-Zaher, 2009), a pattern common in other species (e.g.Pocock, 1935; Jolicoeur, 1959; Timm-Davis et al., 2015; Helgen et al., 2013; Nascimento, 2014; Milenković et al., 2010; Howell et al., 2016; HernándezRomero et al., 2015). In the study of integration patterns, this kind of variation can be a nuisance because differences of this sort usually affect the mean values of populations, as is usually evidenced by the results of Analyses of Variance (ANOVAs). If large, these differences can distort matrix estimates because the covariance pattern will reflect inter-group instead of 
intra-group covariation (see Figure 3.2). Because of this, sources of variation that are not of interest, such as geographical/subspecies variation, sexual dimorphism, age and captivity status have to be removed prior to the estimation of the phenotipic covariance matrix $\mathbf{P}$.

The influence of these factors was evaluated on a case-by-case basis. When information about subspecies or sex were lacking, these factors were first inferred through other means (e.g. geographical information, cranial morphology, skins, etc). Secondly, to validate these estimates, we performed Linear Discriminant Analyses (LDAs) using the individuals with full information as training sets. The discriminant functions obtained were then applied to the individuals with unknown information and the resulting classification was confronted with the inferred one. In cases were both classifications matched, the classification was applied to that specimen. Also, in cases where no previous estimate was possible (e.g. lack of geographical information or clear sexual dimorphism), information was also assigned if LDA posterior probabilities of classification were high (e.g. $>0.7$ for sexual dimorphism, lower for factors with more classes). All effects were then tested for through univariate and multivariate ANOVAs (MANOVAs) and evaluated with principal component analysis (PCA). Those factors that showed large effect sizes were controlled for using a multivariate linear model approach. The covariance matrix of the residuals of the linear model can be interpreted as the pooled within-groups covariance matrix. Table D.1 shows the sources of variation controlled for in each species. Species with no factors to be controlled were processed through a linear model with just the intercept. 

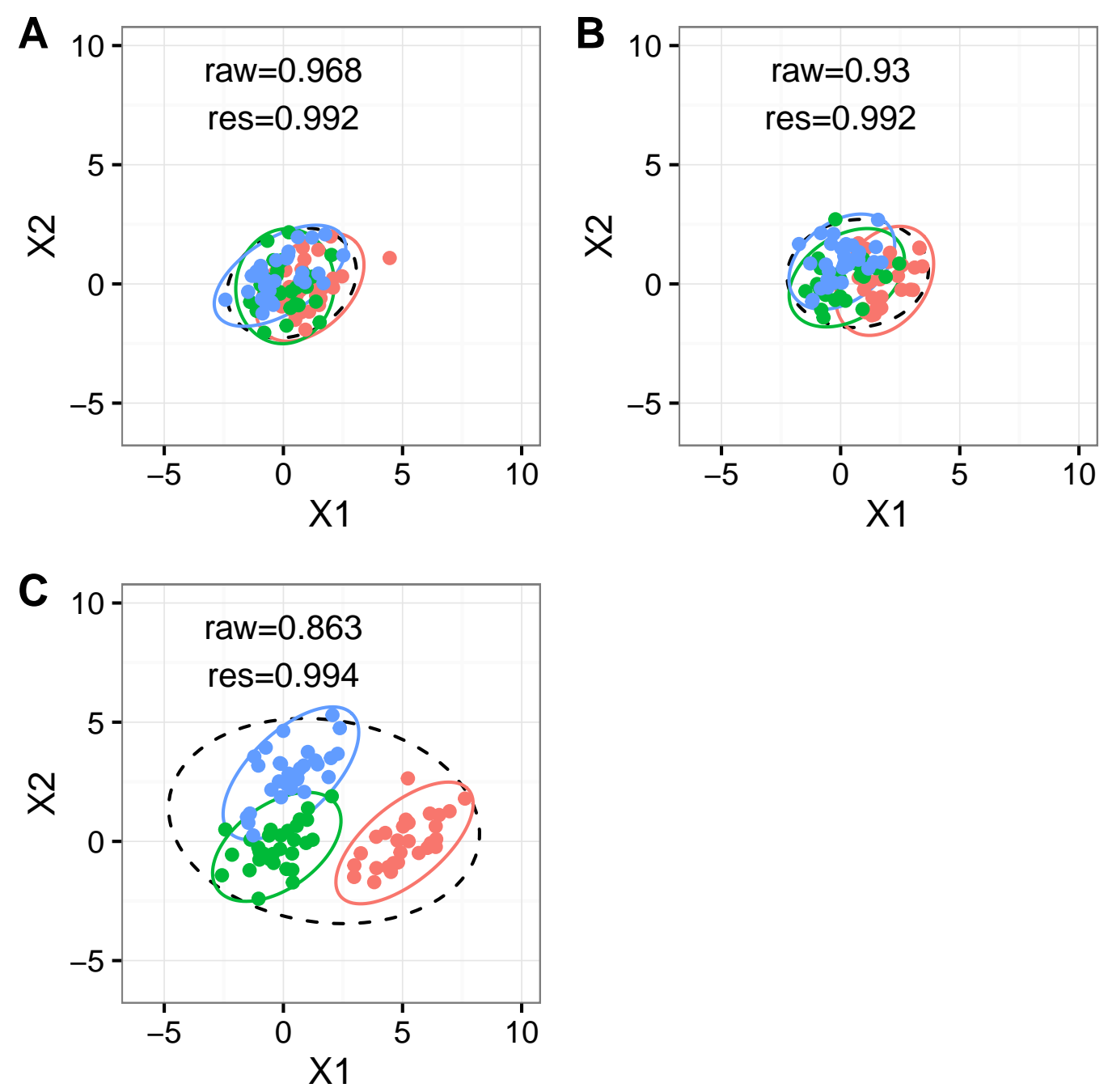

Figure 3.2: Example of the impact of differences in group averages in the estimate of the covariance matrix. A- 3 groups with little differentiation between their means. B- The group averages were multiplied by 2 in relation to A. C-The group averages were multiplied by 5 in relation to A. Dashed ellipsis represents the covariance matrix of the full sample without controlling for fixed (group) effects. raw and res refers to the Random Skewers similarity between the sample covariance matrix (empirical) and the populational covariance matrix used in the simulation for matrices estimated on raw and residual data. 


\section{Matrix similarity, repeatability and rarefaction analysis}

Matrices were compared using the Random Skewers, or RS (Cheverud, 1996b;

Cheverud and Marroig, 2007) method. In RS, each matrix under comparison is multiplied by a set of randomly generated vectors ("skewers"), and each pair of response vectors is compared through vector correlation. The mean correlation between all pairs of vectors is taken as a similarity statistic between both matrices. The RS method can be fully interpreted within the theoretical framework of quantitative genetics, in which the skewers can be viewed as random selection gradients $(\beta)$ that are applied on a population with a genetic covariance matrix $\mathbf{G}$, producing an evolutionary responses $\Delta \mathbf{z}$, as for Equation (3.1). Given that we are using $\mathbf{P}$ as a proxy for $\mathbf{G}$, the use of RS can be interpreted as a measure of the capacity of different species to respond similarly to natural selection.

Since covariances are sample estimates, their precision can be negatively influenced by low sample sizes, therefore misrepresenting the true matrix similarity among groups. To circumvent that problem we corrected observed similarities as $r_{a d j}=r_{o b s} /\left(\sqrt{t_{1} t_{2}}\right)$, were $r_{a d j}$ is the adjusted similarity, $r_{o b s}$ is the observed similarity and $\sqrt{t_{1} t_{2}}$ is the harmonic mean between the repeatabilities $t_{1}$ and $t_{2}$ of the matrices being compared, or the maximum correlation expected for that comparison (Cheverud, 1996b). The $r_{a d j}$ obtained this way represents a conservative value of similarity, taking into account the prior expectation that the matrices are equivalent among Mammalian taxa (Marroig and Cheverud, 2001; Oliveira et al., 2009; Porto et al., 2009; Hubbe et al., 2016).

To calculate matrix repeatabilities previous works have utilized two different approaches: Monte Carlo (Marroig and Cheverud, 2001; Porto et al., 2009; Oliveira et al., 2009) and Bootstrap (Goswami et al., 2015; Hubbe et al., 2016). These methods are used to generate multiple replicated datasets in 
order to calculate new covariance matrices. On the Monte Carlo approach, the estimated covariance matrix is used to generate multiple random multivariate data sets, while in the Bootstrap approach the original data is resampled with replacement multiple times. In both cases, the resulting dataset is used to calculate a new covariance matrix to be compared to the original one (through RS in the present case). The average similarity is taken as the repeatability measure of that matrix. To evaluate the impact of different (re)sampling methods, we performed a rarefaction analysis of repeatability using both methods on the Canis lupus sample, with sample sizes ranging from 5 to 105. For each sample size 100 subsamples were drawn from the original data (without replacement) and for each sample 1000 Bootstrap and Monte Carlo replicates were produced, totaling 10100000 operations.

In order to evaluate the appropriate sample size for matrix comparison we used two methods in addition to the rarefaction analysis of repeatabilities. First, we obtained repeatabilities for all species with more than 5 specimens, in order to investigate if there is any clear drop in matrices with small sample sizes. Secondly, we performed a similar rarefaction analysis on the Canis lupus sample, comparing subsample estimates with the full sample matrix, in order to evaluate the precision of estimates from smaller sample sizes. This rarefaction was performed with sample sizes ranging from 5 to 105 and with 100 subsamples for each sample size (10100 operations). For each subsample the matrix was estimated and compared to the full sample covariance matrix through RS. Following Goswami (2006b), we confronted rarefied matrix similarity with empirical similarities among species in order to evaluate what is an adequate sample size. For the species with sufficient samples, we calculated the pairwise raw and adjusted similarity (RS) values. 


\section{Cluster Analysis}

To inspect the presence of any clustering in the patterns of morphological integration as revealed by the RS analysis, we used a data-mining technique called k-medoids (Kaufman and Rousseeuw, 1987). This technique is analogous to the k-means method, but differs by being applicable directly on a distance or dissimilarity matrix without loss of information. The k-medoids algorithm consists in the selection of k elements of the sample, the so called "medoids", and their associated clusters in order to minimize the criteria L defined as

$$
L=\sum_{i=1}^{k} \sum_{j \in C_{i}} d_{i j}
$$

where $\mathrm{j}$ are the elements of the $i^{\text {th }}$ cluster and $d_{i j}$ is the distance or dissimilarity between element $\mathrm{j}$ and the medoid of the cluster $\mathrm{i}$. For a fixed value of $k$, the exact solution was given by Gordon and Vichi (1998) and is implemented on package clue of R Core Team (2016). To implement this procedure on matrix similarity, we transformed the RS matriz into a distance matriz by simply obtaining $1-R S$. The application of the k-medoids algorithm in this case could be viewed as a way of finding clusters of species with matrices that are more similar among themselves then to other groups of species.

In order to find the best number of $k$ partitions, the above procedure was repeated for $k=1, \ldots, n$. Given that the increase of $\mathrm{k}$ leads necessarily to a decrease in $L$ (e.g. if $k=n$ then $L=0$ ), this criteria cannot be used to compare among different values for $k$. Instead, we utilized the CalinskiHarabasz (CH) criterion (Caliński and Harabasz, 1974) which is defined as

$$
C H_{k}=\frac{S S_{B}}{S S_{W}} * \frac{(n-k)}{(k-1)}
$$

in which $S S_{B}$ and $S S_{W}$ are the between and within-cluster sum of dissimilar- 
ities respectively. According to this criterion, as $k$ approaches $n$, the second hand of the equation approaches 0 , consequently penalizing more complex arrangements. The $\mathrm{CH}$ criterion is convenient because it has a direct relation with $F$ - ratios used on Analyzes of Variance (ANOVAs). For dissimilarity matrices, the $S S_{B}$ e $S S_{W}$ portions of the equation can be calculated as the sum of distances between groups and the sum of distances within groups respectively (McArdle and Anderson, 2001; Anderson, 2001). Given that the $\mathrm{CH}$ criterion is not defined for one group $\left(S S_{B}=0\right)$ we employed a non-parametric multivariate analysis of variance (NP-MANOVA, Anderson, 2001) on the cluster obtained for $k=2$ in order to evaluate the validity of that grouping. The significance of the NP-MANOVA was obtained by 10000 permutations of the distance matrix (Anderson, 2001). All analyses were done on the uncorrected and corrected values of RS. Additionally we performed the analysis using taxonomic groupings that corresponded to the clusters found adding the coefficient of morphological integration $\bar{r}^{2}$ as a covariate to investigate if the observed patterns could be due only to variation in morphological integration. This was done using a type II NP-MANOVA implemented in the package RVAideMemoire (Hervé, 2016).

\section{Modularity, Evolutionary flexibility, magnitude of integration and percentage of variation}

To investigate the nature of differences between covariance structures we obtained modularity indexes, evolutionary flexibility, magnitude of integration and percentage of variation explained for each species (Porto et al., 2009; Marroig et al., 2009).

Firstly, we tested modularity hypotheses based on functional matrix theory (Moss ML, 1960) adapted primarily for primates (Cheverud, 1982) and further verified on all major mammalian clades, including Carnivora (Porto 
et al., 2009, 2013). This was done by first building "hypothetical matrices": i.e. trait*trait matrices that contains 1 s for all entries within modules and 0s for all other entries (Cheverud, 1995, 1996b). Each covariance matrix was then transformed into their correlation conterpart and the correlation between those matrices and the hypothetical ones were calculated by taking the Pearson product-moment correlation between the lower triangle of both matrices without the diagonal. Since the entries on a correlation matrix are not independent data points, the significance of those correlations were assessed through 1000 permutations (Cheverud, 1982).

Following Porto et al. (2009) we tested the Oral, Nasal, Zygomatic, Vault and Base cranial module hypotheses as well as the two main cranial regionsFace and Neurocranium- containing characters of somatic/late and neural/early growth, respectively. Additionally, we also tested composite hypotheses that include more than one module/region. This is done by summing different hypothetical matrices and setting all values larger than 1 to 1. Specifically we used two composite hypotheses: "Total" that includes all modules and "Neuroface" that evaluates both cranial regions jointly.

As a measure of modularity we calculated the AVGratio for all modularity hypotheses. The AVGratio is calculated as the ratio between the average correlation of traits within a given hypothetical module (AVG+; 1 s in the hypothetical matrix) and the average correlation among other traits and between modules (AVG-; 0s in the hypothetical matrix, Cheverud, 1995, 1996a; Marroig et al., 2004). If the ratio is higher than 1, this means that the characters inside a module are more integrated than those outside or between modules. If the value is lower than 1 , then the within-module correlations are lower than those outside the module.

Flexibility expresses the capacity of a species to respond evolutionarily in the same direction of natural selection and is measured as the vector cor- 
relation between the selection gradient $\beta$ and the evolutionary response $\Delta \mathbf{z}$.

Since this measure depends on the direction of selection we need to measures along all directions of the phenotypic space to obtain a single value for each species. To do that, we utilize a method that is analog to RS, in which a number of random normalized selection gradients are generated and applied to each matrix using the multivariate breeders equation (Lande, 1979). Flexibility is calculated for each pair of $\beta$ and $\Delta \mathbf{z}$ and the average flexibility $\bar{f}$ is used as an overall measure of evolutionary flexibility (Marroig et al., 2009). This method is usually employed on the full phenotypic space, but it can be easily adapted to explore the flexibility of a subset of characters or modules representing different directions (Garcia et al., 2014). The value of flexibility for that subset can be calculated as $\bar{f}$ based on randomly generated normalized vectors that have positive values for the entries associated with that subset and 0 for everything else. This was done for each individual modular hypothesis and for all individual traits. All $\bar{f}$ were calculated on 1000 random vectors with the exception of the ones for individual traits because only one normalized vector is possible in those cases.

To measure the overall morphological integration of the skull we calculated the average coeficient of determination of each matrix $\bar{r}^{2}$. This coefficient is simply the average of the squared correlation coefficients among all traits. Since $\overline{r^{2}}$ measures global integration of the skull, we also calculated the average $r^{2}$ for each character as the average square correlation between one character and all others (each line/column of a correlation matrix). We could also calculate average $r^{2}$ values for modular hypothesis, but that information is already contained in the AVGratio, specifically AVG+.

Finally, we also calculated the proportion of variance contained in each character and module in order to inspect shifts in the distribution of variation of the skull among different groups. We also calculated the relative 
amount of variance associated with size as it is correlated with modularity, flexibility and integration measures (Porto et al., 2009; Marroig et al., 2009). Here size is considered to be the main factor influencing all characters (Wright, 1968) and its variance can be calculated as the eigenvalue associated with the first eigenvector of the covariance matrix of linear measurement data (Bookstein, 1989).

To investigate differences in the pattern of morphological integration between the clusters found, we tested the differences between groups using t-tests on modularity indexes (AVGratio, AVG+, AVG-), flexibility ( $\bar{f}$ for all skull, for modules/regions and characters), morphological integration indexes ( $\bar{r}^{2}$ for all skull and for characters) and relative variances (for each character, cranial modules/regions and size). Given that measures of modularity, relative variation and flexibility are thought to be influenced by (or correlated to) $\overline{r^{2}}$ (Porto et al., 2009; Marroig et al., 2009), we also performed Analyses of Covariances (ANCOVAs) on these measures using $\sqrt{r^{2}}$ as a covariate. The square root was obtained in order to linearize the data and to put the variable on the same scale as AVG+ and AVG-. Multiple tests were corrected for using Bonferroni.

\section{Selection Response Decomposition}

In order to diagnose which characters are responsible for the observed disparity in morphological integration patterns we employed the Selection Response Decomposition (Marroig et al., 2011). This method is based on the same principle as RS in which selection gradients are applied to two matrices and their responses are compared. On SRD, instead of comparing $\Delta \mathbf{z}$ as a whole, the evolutionary response is decomposed into vectors which contains the elements of the matrix multiplication $\mathbf{G} \beta$. For a given character $i$ 
the vector of evolutionary response is arranged as follows

$$
\left[G_{i 1} \beta_{1}, G_{i 2} \beta_{2}, \ldots, G_{i n} \beta_{n}\right]
$$

The sum of the elements of this vectors is equal to the evolutionary response of that individual character (Lande and Arnold, 1983; Marroig et al., 2011; Savell et al., 2016). These character vectors are then compared between species through vector correlation, producing a distribution of SRD similarity values between two species for each character. For a large number of group comparisons, one can construct a pairwise matrix of similarity between species analogous to RS for each character. This method is implemented in the evolgg R package (Melo et al., 2015).

In order to measure the influence of each character on the variation of morphological integration, each SRD matrix was correlated with the RS matrix through matrix correlation, using 1000 permutations to assess the significance. Each matrix was also subjected to the k-medoids method in order to inspect if the same clusters seen in RS can be found for each individual character SRD matrix. Finally, we performed NP-MANOVAs on each SRD matrix using the groupings suggested by the analysis of the RS in order to diagnose which characters are more associated with the differences found.

\section{Results}

\section{Repeatability, rarefaction and minimum sample size}

The rarefaction analysis of repeatability estimates on the Canis lupus sample indicates that both Monte Carlo and Bootstrap methods give on average the same result when sample sizes are greater than 8 (Figure 3.3A), Pearson's $r=0.998)$. When sample sizes are small $(n=5)$, the Monte Carlo approach 

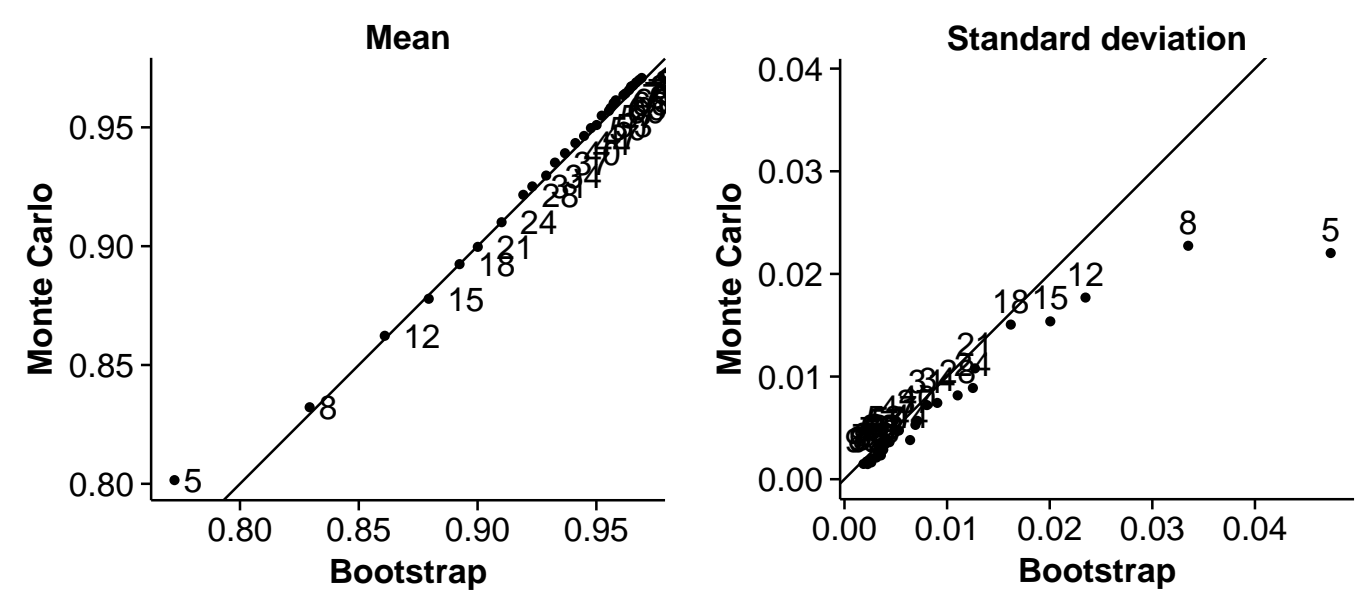

Figure 3.3: Rarefaction analysis of repeatabilities estimated through Monte Carlo and Bootstrap approaches on the Canis lupus sample. The black line has slope $=1$ and intercept $=0$ representing when both repeatability estimates would be equal. Numbers represent sample sizes.

shows a bias towards higher values. Additionally, the standard deviation of the estimates is higher for the Bootstrap method when sample sizes are smaller than 18 (Figure 3.3B). Given that both methods provided the same result for the sample sizes chosen here (see below) we focus only on the repeatabilities estimated through Monte Carlo. Figure 2.5 shows the the empirical Monte Carlo repeatabilities for all species with $n>5$. The curve shows a bimodal pattern, with a monotonic decrease in repeatabilities from sample size 100 to 25 , and an abrupt reduction of repeatabilities from 25 to 5 . The majority of values for $n>25$ are above 0.9 and no value is lower than 0.7 , even for $n=5$.

The rarefaction analysis of the similarity between subsamples and the full sample of the Canis lupus matrix shows that sample sizes $>35$ have a similarity to the original matrix $>0.9$ (Figure 3.4A), and higher on average than all empirical similarities (Figure 3.4B). Values between 35 and 25 have $\mathrm{RS}=0.8-0.9$ (Figure $3.4 \mathrm{~A}$ ) and are on average superior to $95 \%$ of the empirical similarities between families values and $90 \%$ of the between genera values. 

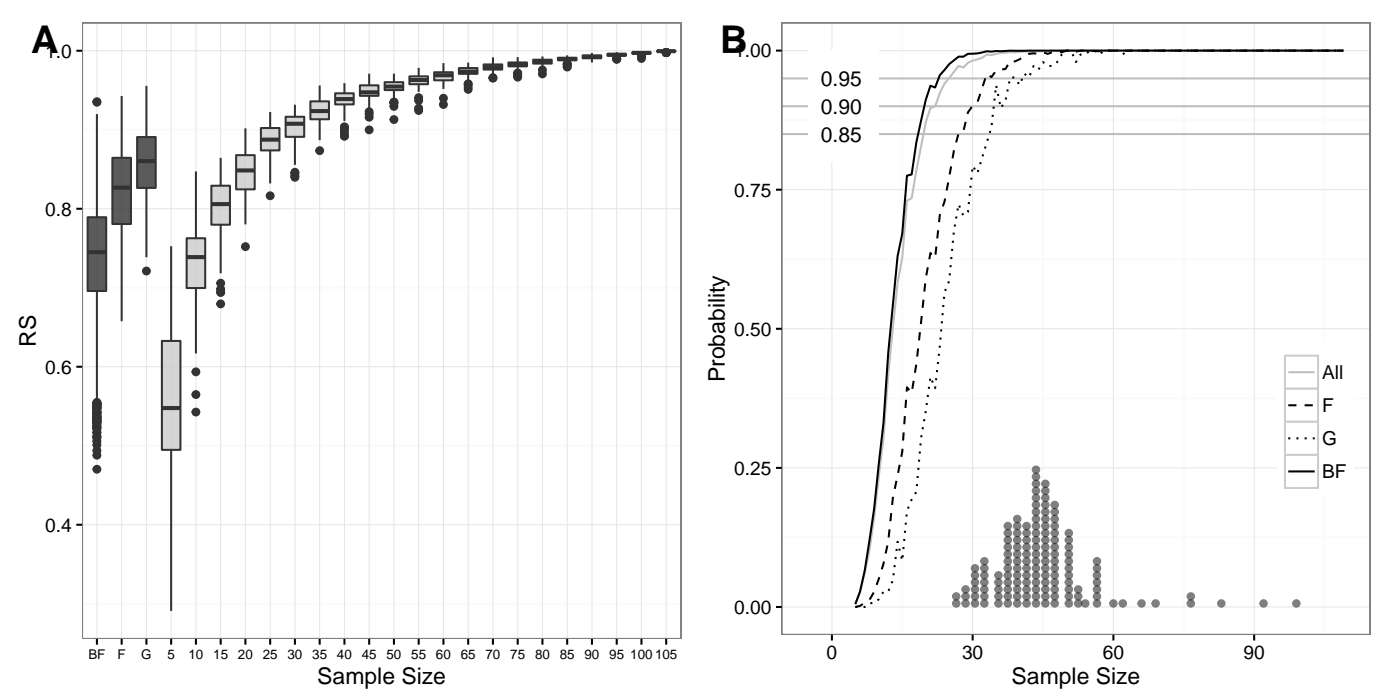

Figure 3.4: Analysis of rarefaction on the Canis lupus sample. A. Matrix similarity (RS) between subsamples of the matrix and the full sample matrix compared to empirical similarities. B. Average percentile of the rarefied value on the empirical distributions. BF- Between Families. F- Within families and between genera. G- Within genera. All- Full sample. Dots represents distribution of sample sizes $>24$ showing that the majority of the sample is larger than 35 .

Given these results we chose to include all species with $n>25$. By doing this, we minimize the effects of low repeatabilities for samples $n<25$ and allow for broad scale comparisons while including many rare taxa (Figure 3.4B, Table D.1).

\section{Matrix similarity and Cluster Analysis}

Figure C. 2 shows the 10296 pairwise Random Skewers comparisons for all 144 species. All observed and corrected values were highly correlated (Pearson's $r=0.993)$. Henceforth, all corrected values will be displayed between parenthesis, unless otherwise stated. Values ranged from $0.442-0.902(0.470-$ $0.956)$ with an average of $0.705 \pm 0.070(0.749 \pm 0.072)$. The highest values were observed for within-genera comparisons, ranging from $0.66-0.90$ $(0.72-0.95)$, with an average value of $0.80 \pm 0.05(0.85 \pm 0.05)$. Values for comparisons within families but between different genera (henceforth "be- 
tween genera") had an intermediate value, ranging from $0.61-0.90$ (0.66$0.94)$ with average values of $0.77 \pm 0.06(0.82 \pm 0.06)$. The lowest values were observed for comparisons between families, that ranged from $0.44-0.88$ $(0.47-0.88)$ with an average of $0.70 \pm 0.07(0.73 \pm 0.07)$. Only three comparisons had a corrected value $<0.5$ and they all involved the comparison between a Piniped (Odobenus rosmarus and Mirounga leonina) and a Fissiped (Mephitis macroura and Hemigalus derbyanus).

There seems to be a clear demarcation between Canidae species and the rest of Carnivora (Figure C.2). RS values within Canidae ranged from $0.699-0.903(0.742-0.956)$, with an average of $0.809 \pm 0.041(0.856 \pm 0.041)$, while the values without Canidae ranged from $0.444-0.901(0.471-0.945)$, with an average of $0.711 \pm 0.067(0.756 \pm 0.069)$. Values between Canidae and non-canid Carnivores ranged from $0.481-0.844(0.506-0.887)$ with an average of $0.679 \pm 0.066(0.726 \pm 0.069)$. This suggests that canid species are more similar among eachother and slighly more dissimilar to the rest of rest of the Carnivora.

According to the $\mathrm{CH}$-index criteria for the k-medoids clustering method, the optimal partition of the data is $\mathrm{k}=2$ for both observed and corrected values (Figure 3.6A). The NP-MANOVA analysis on the two resulting clusters supports the separation for both observed and corrected values (Table 3.1). For the observed RS values, the clusters largely differentiates Canidae (with 5 exceptions: Speothos venaticus, Lycaon pictus, Canis adustus, Nyctereutes procyonoides and Lycalopex culpaeus) from non-canid Carnivora (Figure 3.6B). For the corrected values, the results are not so clear cut, with all species of Canidae forming one cluster, along with some species from other families.

The result of the NP-MANOVA using the distinction between Canidae and non-canid Carnivora as a factor ("Canidae" factor) shows that the difference between groups is also significant, with Canidae explaining slightly 


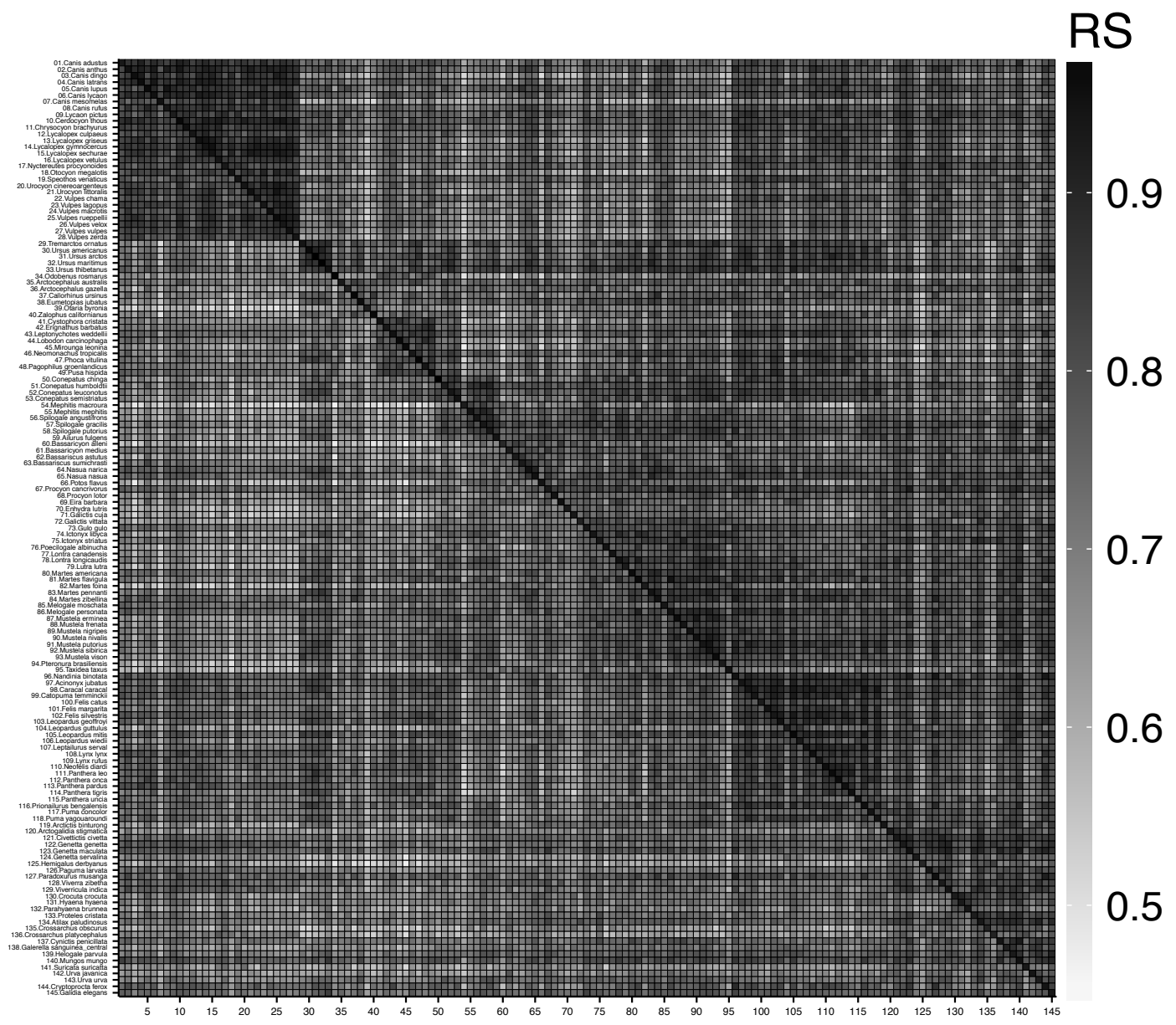

Figure 3.5: Heat map representing pairwise Random Skewers comparisons. Values below and above the diagonal are the observed and corrected similarities, respectivelly. Values at the diagonal are repeatabilities. 1-28Canidae; 29-33- Ursidae; 34- Odobenidae; 35-40- Otariidae; 41-49-Phocidae; 50-58-Mephitidae; 59-Ailuridae; 60-68-Procyonidae; 70-95-Mustelidae; 96Nandiniidae; 97-118-Felidae; 119-129- Viverridae; 130-133- Hyaenidae, 134143-Herpestidae, 144-145- Eupleridae 
Table 3.1: Non-Parametric Manova analysis of k-medoid Clusters and Taxonomy classification. Sum Sq-Sum of Squares.Mean Sq- Mean Squares.DfDegrees of Freedom. $R^{2}$ - Coefficient of determination (values between parenthesis is the coefficient of determination adjusted for multiple factors $\left.R_{a d j}\right)$.F- Pseudo-F statistic. $p$ - probability given the null-hypothesis.

\begin{tabular}{lllllll} 
Observed & Sum Sq & Mean Sq & Df & $R^{2}$ & $F$ & $p$ \\
\hline Cluster & 0.254 & 0.254 & 1 & $0.185(0.179)$ & 32.231 & 0.001 \\
$\begin{array}{l}\text { Residuals } \\
\text { Total }\end{array}$ & 1.119 & 0.008 & 142 & 0.815 & & \\
& & & 143 & & & \\
Canidae & 0.288 & 0.288 & 1 & $0.209(0.203)$ & 37.633 & 0.001 \\
$\begin{array}{l}\text { Residuals } \\
\text { Total }\end{array}$ & 1.085 & 0.008 & 142 & 0.791 & & \\
Family & 0.653 & & 143 & & & \\
$\begin{array}{l}\text { Residuals } \\
\text { Total }\end{array}$ & 0.720 & 0.047 & 14 & $0.476(0.414)$ & 8.361 & 0.001 \\
& 1.373 & & 143 & & & \\
Corrected & Sum Sq & Mean Sq & $D f$ & $R^{2}$ & & \\
\hline $\begin{array}{l}\text { Cluster } \\
\text { Residuals }\end{array}$ & 0.298 & 0.298 & 1 & $0.217(0.189)$ & 34.289 & 0.001 \\
Total & 1.533 & 0.009 & 142 & 0.899 & & \\
& & & 143 & & & \\
Canidae & 0.318 & 0.318 & 1 & $0.231(0.226)$ & 37.095 & 0.001 \\
Residuals & 1.215 & 0.009 & 142 & 0.885 & & \\
Total & 1.533 & & 143 & & & \\
& & & & & & \\
Family & 0.809 & 0.058 & 14 & $0.589(0.541)$ & 10.295 & 0.001 \\
Residuals & 0.724 & 0.006 & 129 & 0.527 & & \\
Total & 1.533 & & 143 & & &
\end{tabular}



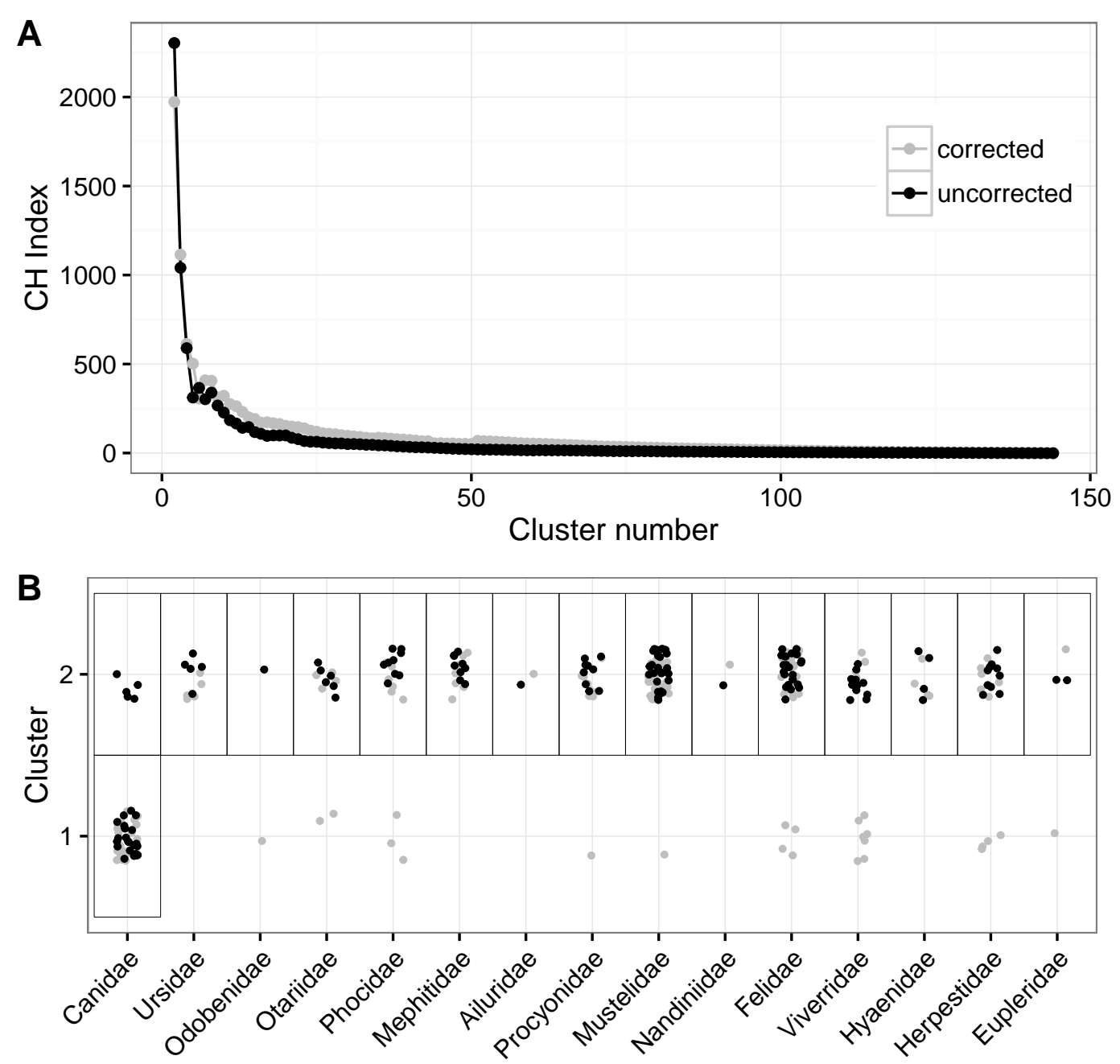

Figure 3.6: K-medoids clustering analysis on similarity matrix through Ramdon Skewers (RS). A. Calinski-Harabasz index by number of cluster for observed and corrected RS values. B. Species cluster assigment for the optimal partition of the similarity matrix $(\mathrm{k}=2)$ for the K-medoids clustering analysis. Each dot represent one species. Black and gray dots are cluster assigned for observed and corrected similarities respectively. Rectangular frames highlight the groupings found for the observed RS similarity. 
more variation than the detected cluster (Table 3.1). Additionally, Canidae alone explains almost half of the variation that is explained by using all families as factors (Canidae: $\left.R_{a d j} \approx 0.20\right)$; All Families: $\left(R_{a d j} \approx 0.40\right.$, Table 3.1). When we test the differences of Canidae using $\overline{r^{2}}$ as a covariate we find that the difference between groups is still significant even if we account for the variation in the overall magnitude of morphological integration (Table 3.2). Also, the addition of $\bar{r}^{2}$ to the NP-MANOVA barely changed the amount of variation explained by Canidae/non-canid Carnivora (observed$R^{2}=0.210$; corrected $-R^{2}=0.220$ ), while the variation of morphological integration explained a significant (albeit smaller) amount of variation in RS (observed- $R^{2}=0.140$; corrected- $R^{2}=0.113$ ). Together these results suggests that Canidae have the most distinct pattern of morphological integration within Order Carnivora. The next tests were conducted in order to explicitly diagnose the differences between this family and the others.

\section{Modularity, Evolutionary flexibility, magnitude of integration and percentage of variation}

The results for the modularity tests can be found in Table 3.3. Modularity was statistically significant $(p<0.05)$ mainly for the Nasal and Oral hypotheses, with rejection of the null hypothesis in 67.4 and $77.1 \%$ of the cases, respectively. The Zygomatic module was largely undetected, with the exception of a few canids, otariids, procyonids and hyenids, being detected only in $4.2 \%$ of the cases. Both the Base and Vault modules were not detected in any case. The Face was detected in almost all instances (91.7\%), while the Neurocranium was detected in none. For composite hypotheses, NeuroFace was detected in almost all cases (97.9\%) while the Full hypothesis was detected on a few (34.7\%). When we look at the family level, the results seems to be consistent with the overall pattern, with the Oral mod- 


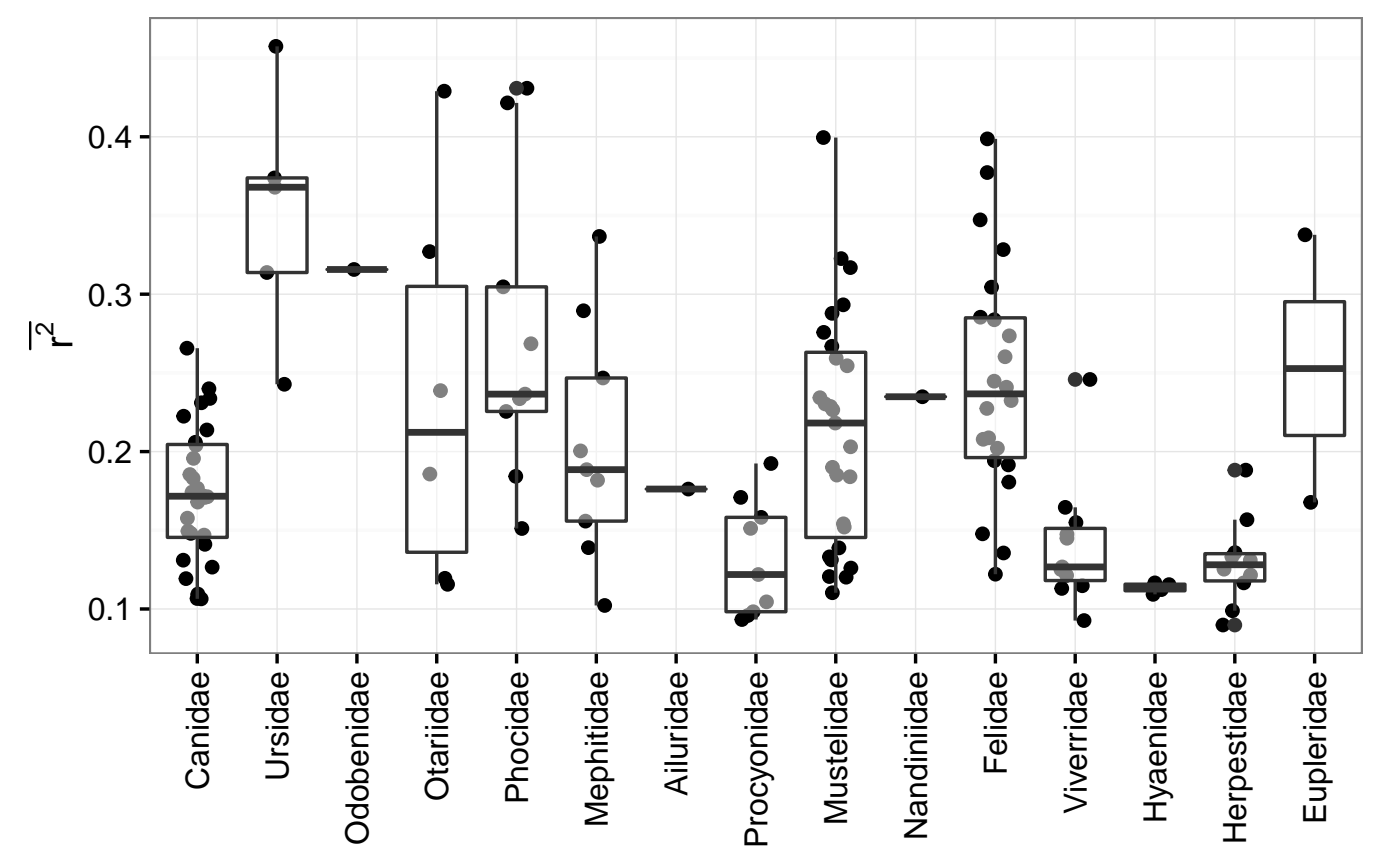

Figure 3.7: Overall morphological integration $\left(\bar{r}^{2}\right)$ of different families of Carnivora. Each dot represents one species.

ule being detected in the majority of cases, followed by the Nasal and then the Zygomatic modules (when detected). The only clear exception seems to be Canidae, that had a perfect rate of detection for the Nasal module $(100 \%)$, followed by the Oral module (88.9\%). A $\chi$ - squared test for similarity of proportions showed, however, that after correction for multiple tests no family deviated from what was expected for the full sample $(p>0.1$ for all tests), including the Nasal and Oral modules for Canidae ( $p=0.103$ and 1.000 respectively).

Overall morphological integration $\left(\overline{r^{2}}\right)$ varied widely among families (Figure 3.7). Both the t-tests and the ANCOVAs with $\sqrt{r^{2}}$ as a covariate indicate that Canidae have a Nasal module that has a higher AVGratio, evolutionary flexibility and proportion of variation than non-canid carnivorans (Table 3.4, Figures 3.8 to 3.10). Both tests also indicate that Canids have a more variable Oral module, a less flexible and variable Base, as well as less variable Vault and Zygomatic modules (Figures 3.9 and 3.10). Additionally, the AN- 
Table 3.2: Type II Non-Parametric Manova analysis on RS for the distinction between Canidae and non-canid Carnivora with $\overline{r^{2}}$ as a covariate. Sum SqSum of Squares.Mean Sq- Mean Squares.Df- Degrees of Freedom. $R^{2}$ - Coefficient of determination.F- Pseudo-F statistic. $p$ - probability given the nullhypothesis.

\begin{tabular}{lcccccc} 
Observed & Sum Sq & Mean Sq & $D f$ & $R^{2}$ & $F$ & $p$ \\
\hline$r^{2}$ & 0.193 & 0.193 & 1 & 0.140 & 30.244 & 0.001 \\
Canidae & 0.289 & 0.289 & 1 & 0.210 & 45.362 & 0.001 \\
$\bar{r}^{2}$ : Canidae & 0.001 & 0.001 & 1 & 0.001 & 0.168 & 0.992 \\
Residuals & 0.892 & 0.006 & 140 & 0.649 & & \\
Total & 1.373 & & 143 & 1.000 & &
\end{tabular}

$\begin{array}{lllllll}\text { Corrected } & & & & & & \\ \overline{r^{2}} & 0.155 & 0.155 & 1 & 0.113 & 20.501 & 0.001 \\ \text { Canidae } & 0.303 & 0.303 & 1 & 0.220 & 40.061 & 0.001 \\ \overline{r^{2}} \text { :Canidae } & 0.003 & 0.003 & 1 & 0.002 & 0.403 & 0.821 \\ \text { Residuals } & 1.058 & 0.008 & 140 & 0.770 & & \\ \text { Total } & 1.533 & & 143 & 1.117 & & \end{array}$

Table 3.3: Modularity tests performed on functional matrix hypotheses. Values are percentages of times that a given hypothesis was rejected through matrix permutation tests. Module Hypotheses- Oral, Nasal, Zygomatic, Vault, Base. Region Hypotheses- Face, Neurocranium. Composite hypotheses- NeuroFace, Full

\begin{tabular}{lrrrrrrrrrr}
\hline family & $\mathrm{n}$ & Oral & Nasal & Zygomatic & Vault & Base & Face & Neurocranium & NeuroFace & Full \\
\hline Canidae & 27 & 0.889 & 1.000 & 0.037 & 0.000 & 0.000 & 0.963 & 0.000 & 1.000 & 0.407 \\
Ursidae & 5 & 0.600 & 0.600 & 0.000 & 0.000 & 0.000 & 1.000 & 0.000 & 1.000 & 0.000 \\
Odobenidae & 1 & 1.000 & 1.000 & 0.000 & 0.000 & 0.000 & 1.000 & 0.000 & 1.000 & 0.000 \\
Otariidae & 6 & 0.167 & 0.500 & 0.333 & 0.000 & 0.000 & 1.000 & 0.000 & 0.833 & 0.000 \\
Phocidae & 9 & 0.889 & 0.556 & 0.000 & 0.000 & 0.000 & 1.000 & 0.000 & 1.000 & 0.111 \\
Mephitidae & 9 & 0.556 & 0.222 & 0.000 & 0.000 & 0.000 & 0.667 & 0.000 & 1.000 & 0.111 \\
Ailuridae & 1 & 0.000 & 1.000 & 0.000 & 0.000 & 0.000 & 1.000 & 0.000 & 1.000 & 1.000 \\
Procyonidae & 9 & 0.667 & 0.778 & 0.222 & 0.000 & 0.000 & 1.000 & 0.000 & 1.000 & 0.667 \\
Mustelidae & 27 & 0.815 & 0.556 & 0.000 & 0.000 & 0.000 & 0.889 & 0.000 & 0.926 & 0.333 \\
Nandiniidae & 1 & 1.000 & 0.000 & 0.000 & 0.000 & 0.000 & 1.000 & 0.000 & 1.000 & 0.000 \\
Felidae & 22 & 0.818 & 0.682 & 0.000 & 0.000 & 0.000 & 0.955 & 0.000 & 1.000 & 0.182 \\
Viverridae & 11 & 0.818 & 0.636 & 0.000 & 0.000 & 0.000 & 0.818 & 0.000 & 1.000 & 0.636 \\
Hyaenidae & 4 & 0.500 & 0.500 & 0.250 & 0.000 & 0.000 & 0.750 & 0.000 & 1.000 & 1.000 \\
Herpestidae & 10 & 0.900 & 0.700 & 0.000 & 0.000 & 0.000 & 0.900 & 0.000 & 1.000 & 0.600 \\
Eupleridae & 2 & 1.000 & 1.000 & 0.000 & 0.000 & 0.000 & 1.000 & 0.000 & 1.000 & 0.000 \\
Total & 144 & 0.771 & 0.674 & 0.042 & 0.000 & 0.000 & 0.917 & 0.000 & 0.979 & 0.347 \\
\hline
\end{tabular}


Table 3.4: T-tests and ANCOVA analyses (with $\sqrt{r^{2}}$ as a covariate) for the differences between Canidae and non-canid Carnivora for modularitybased statistics. AVGrat- Ratio between average correlarions within module (AVG+) to average correlation outside module (AVG-). Flex.- Flexibility. $\operatorname{Var}(\%)$ - percentage of variance. Positive and negative values indicate increased or decreased values for Canidae respectively. The Full* entry refers to different concepts for AVGrat (a composite hypothesis) and Flex. (flexibility for the entire structure). ${ }^{*}$-values significant at $\alpha<0.05$ withouth correction for multiple tests. ${ }^{* *}$-values significant at $\alpha<0.05$ with correction for multiple tests.

\begin{tabular}{lrrr} 
T-Test & AVGrat. & \multicolumn{1}{c}{ Flex. } & Var(\%) \\
\hline Oral & 0.001 & $0.030^{* *}$ & $0.065^{* *}$ \\
Nasal & $0.328^{* *}$ & $0.054^{* *}$ & $0.061^{* *}$ \\
Zygomatic & -0.013 & -0.014 & $-0.027^{* *}$ \\
Vault & -0.035 & 0.000 & $-0.046^{* *}$ \\
Base & 0.062 & $-0.040^{* *}$ & $-0.018^{* *}$ \\
Face & 0.108 & $0.022^{* *}$ & $0.064^{* *}$ \\
Neurocranium & $-0.048^{*}$ & $-0.032^{* *}$ & $-0.064^{* *}$ \\
NeuroFace & 0.034 & & \\
Full* & 0.026 & 0.002 & \\
Size & & & -0.002 \\
ANCOVA & & & \\
\hline Oral & -0.066 & $0.020^{*}$ & $0.072^{* *}$ \\
Nasal & $0.259^{* *}$ & $0.043^{* *}$ & $0.067^{* *}$ \\
Zygomatic & -0.017 & $-0.028^{* *}$ & $-0.025^{* *}$ \\
Vault & -0.039 & $-0.021^{*}$ & $-0.060^{* *}$ \\
Base & 0.071 & $-0.054^{* *}$ & $-0.016^{* *}$ \\
Face & 0.050 & $0.019^{*}$ & $0.076^{* *}$ \\
Neurocranium & -0.044 & $-0.047^{* *}$ & $-0.076^{* *}$ \\
NeuroFace & 0.000 & \multicolumn{2}{l}{} \\
Full* & -0.004 & $-0.019^{* *}$ \\
Size & & & $0.044^{* *}$
\end{tabular}


COVA detected a decrease in flexibility of the Zygomatic module as well as a decrease in the overall flexibility and increase in size variance (Figures 3.9 and 3.10). For the cranial regions both tests detects an increase in flexibility and variance in the Face and a decrease of both variables in the Neurocranium (Figures 3.9 and 3.10).

\section{Selection Response Decomposition and Individual Charac- ters}

The k-means analyses for SRD matrices consistently returned $k=2$ as the preferred partition scheme according to the $\mathrm{CH}$ index. Only a few characters showed some degree of taxonomic arrangement, mostly those concentrated on the Nasal and Oral modules. These arrangements however were not as clear cut as the ones observed for RS (Figure 3.11). Given that we want to investigate the distinction between Canidae and non-canid Carnivora, we also used this taxonomic distinction as a factor in NP-MANOVAS for each SRD matrix. The results show that 17 out of 18 characters in the Face showed significant difference between groups, as well as 12 out of 17 characters of the Neurocranium (Table 3.5 and Figure 3.12A). From those characters, the ones that have the largest coefficients of determination $\left(R^{2}=0.161-0.245\right)$ are found in the Nasal and Oral modules, while the lowest values are found in the Vault (with the exception of LD-AS; $R^{2}=0.167$ ).

With the exception of two characters (BA-OPI and JP-AS) all SRD matrices showed a positive significant correlation with the RS matrix according to the the matrix permutation tests Table 3.5. All SRDxRS correlations using corrected values for RS were on average 0.03 lower than the ones for observed RS values. The degree of correlation varied greatly between cranial modules and regions. The Face showed the highest correlations (Figure $3.12 \mathrm{~B}$ ), with 14 (out of 18 ) correlations being higher than 0.5 , while the 


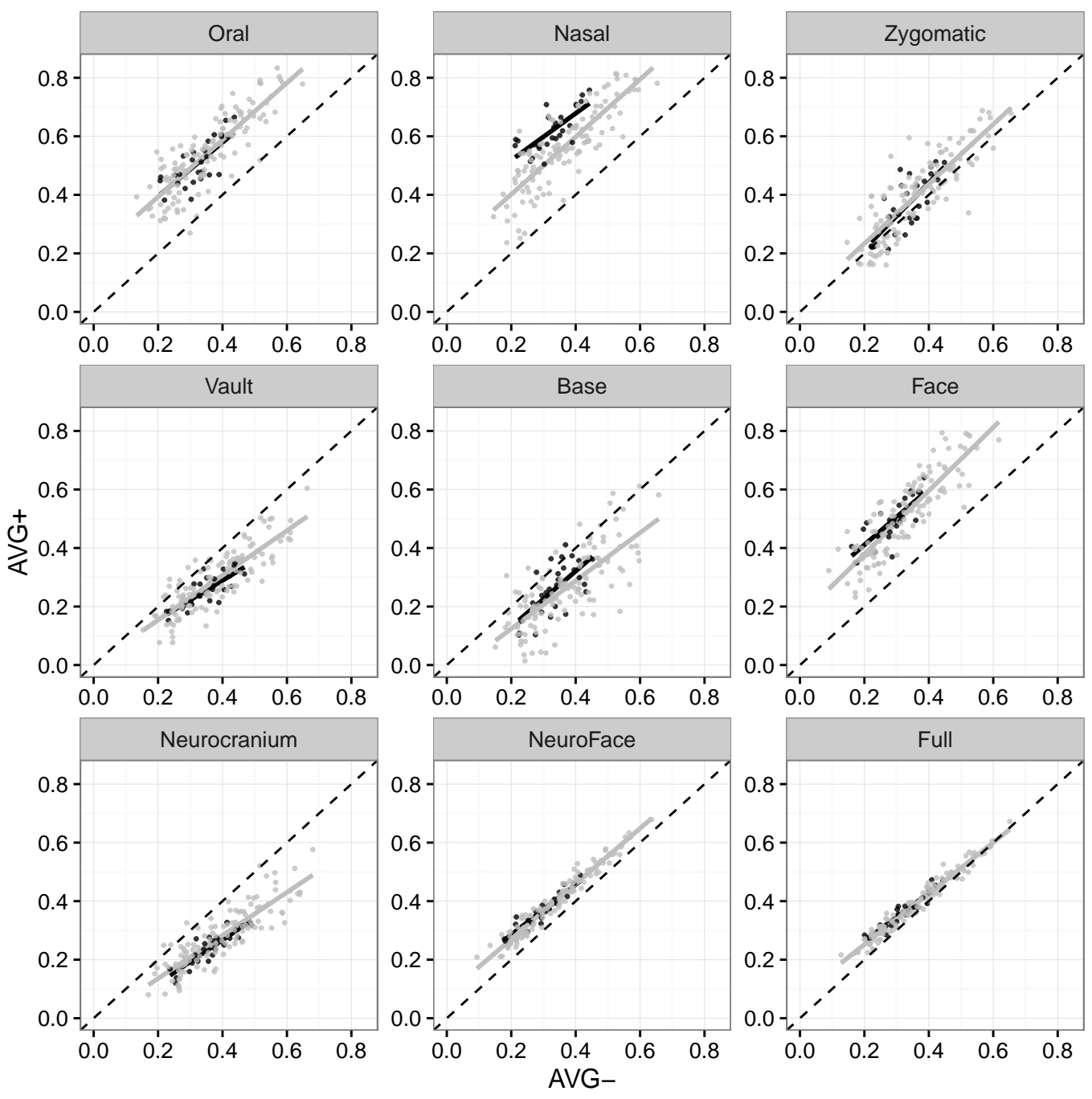

Figure 3.8: Relationship between AVG+ and AVG- for different modularity hypotheses. Black- Canidae. Gray- Non-canid Carnivora. Dashed lineAVG+=AVG-. 


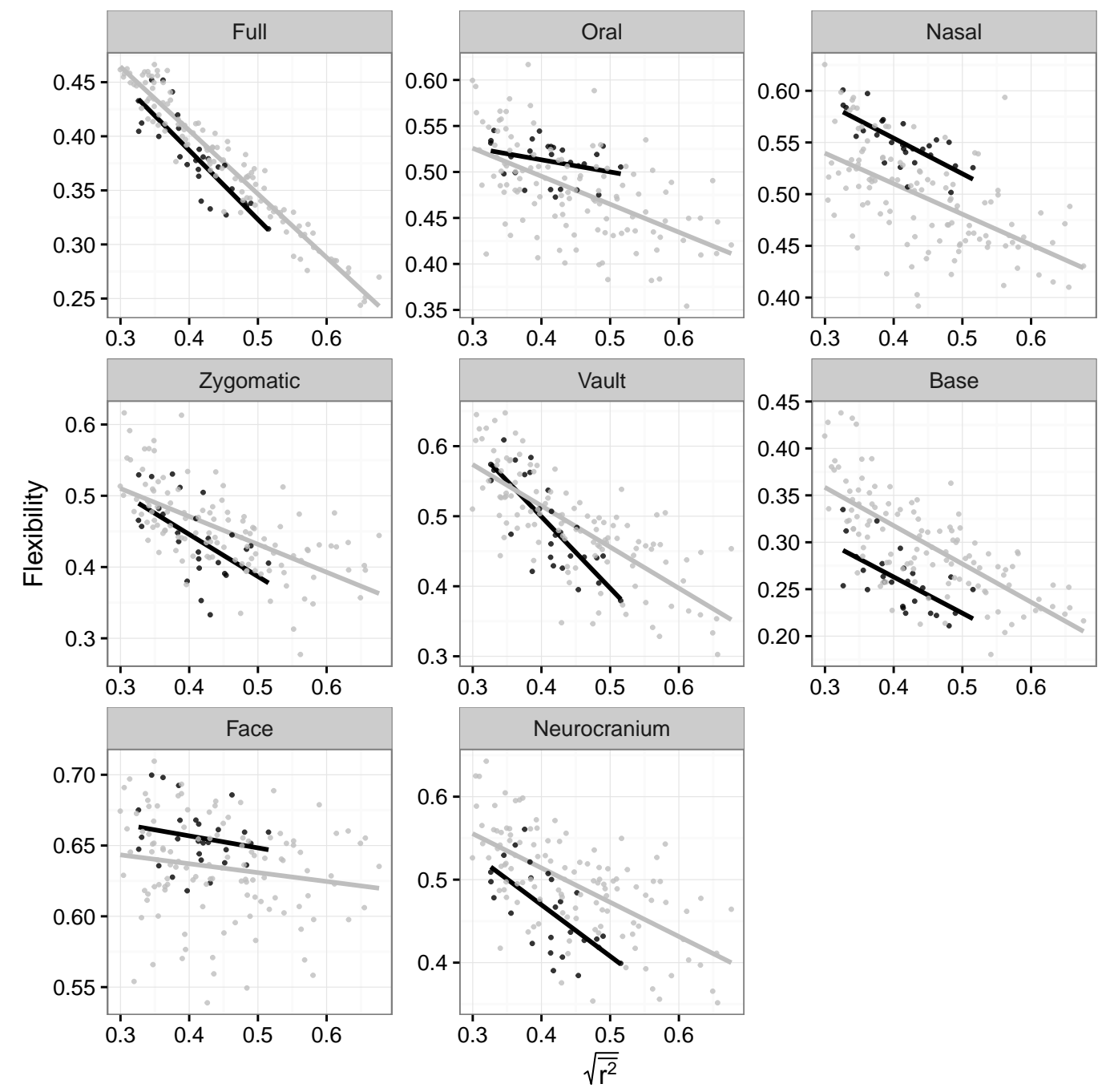

Figure 3.9: Relationship between the morphological integration index $\sqrt{r^{2}}$ and flexibility measured for each module. Black-Canidae. Gray- Non-canid Carnivora. 


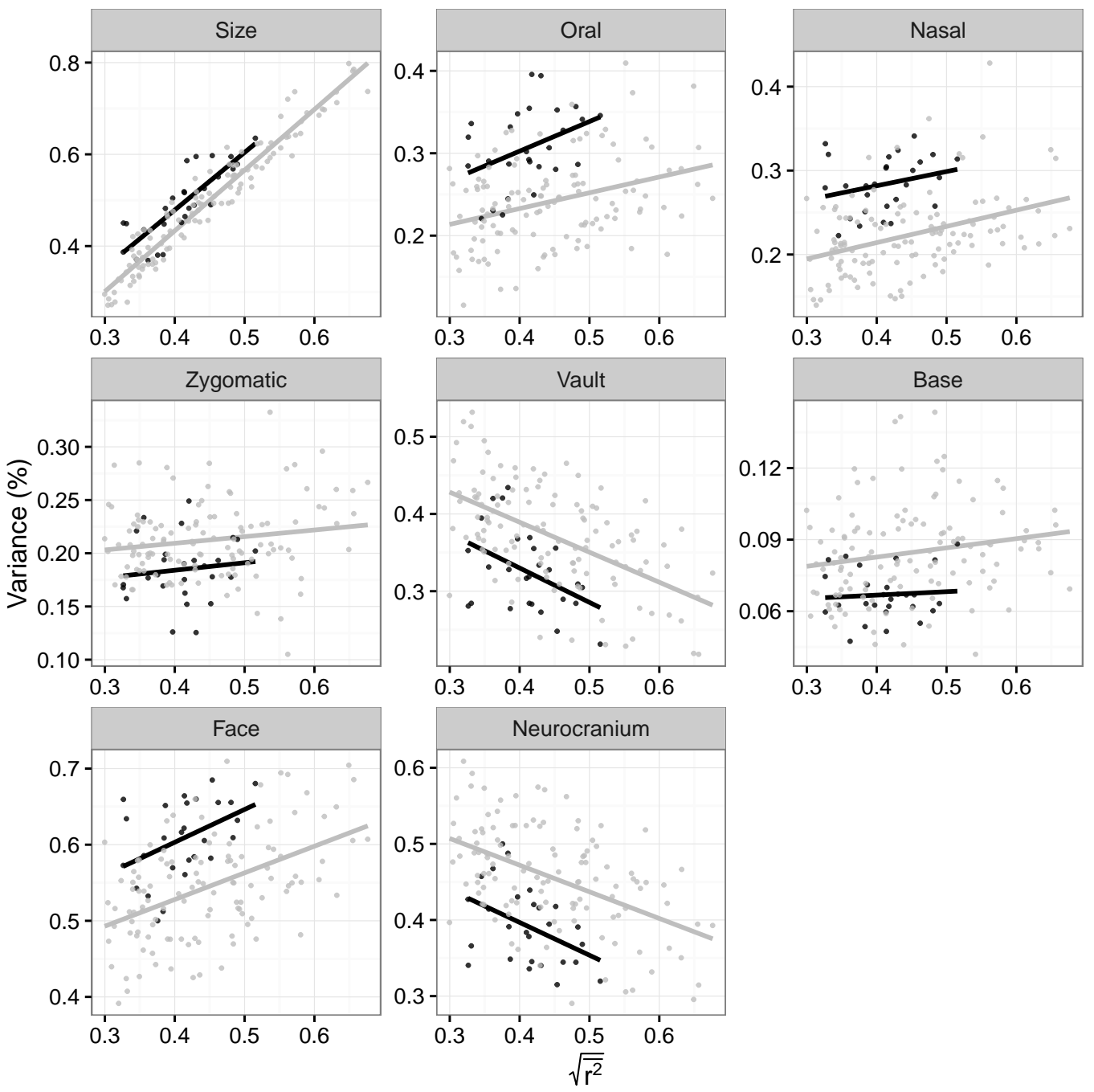

Figure 3.10: Relationship between the morphological integration index $\sqrt{r^{2}}$ and percentage of total variation explained by each module, region and size. Black- Canidae. Gray- Non-canid Carnivora. 


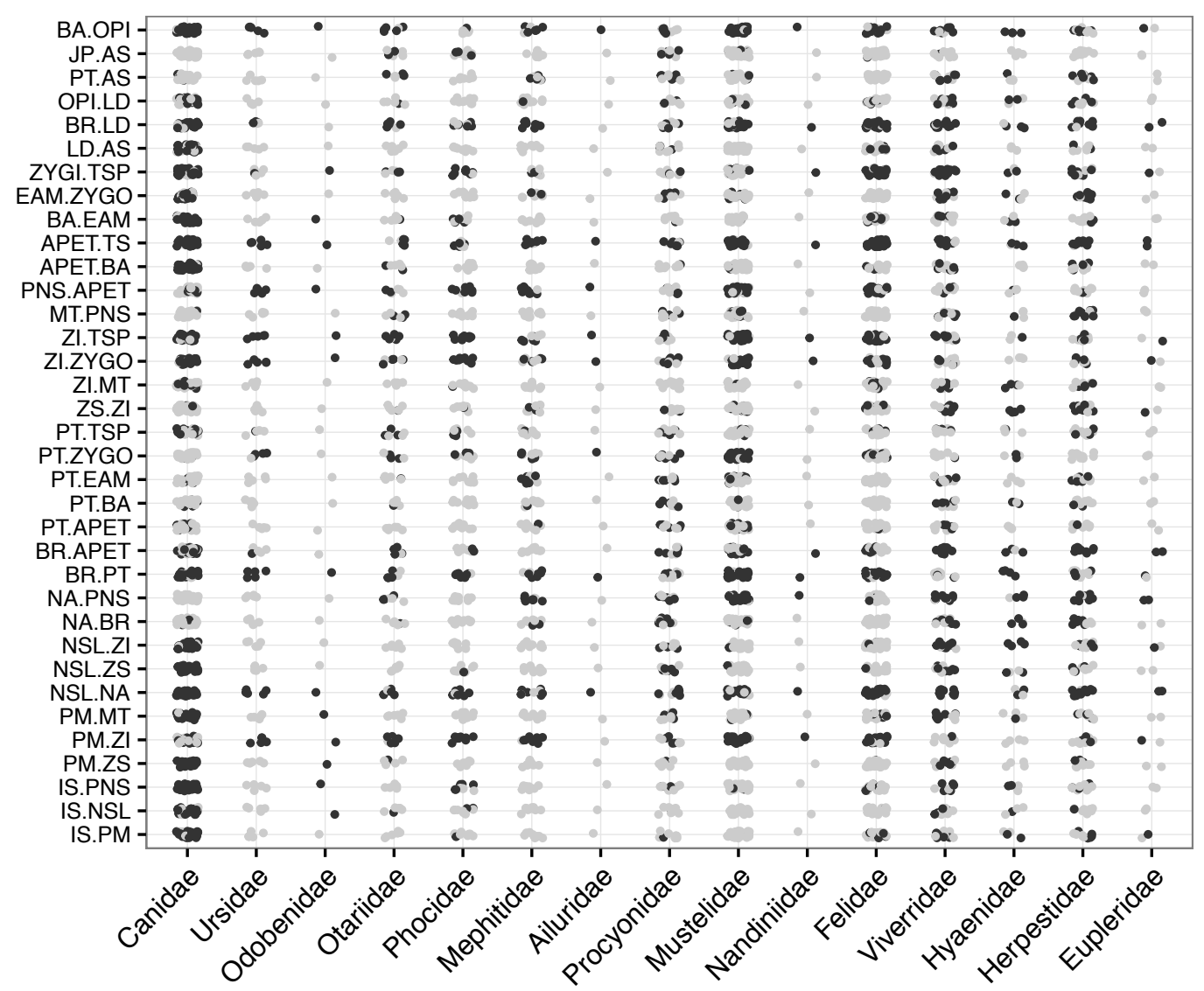

Figure 3.11: K-medoids clustering analysis on similarity matrix through the SRD matrices for $\mathrm{k}=2$. Different colors represents different group identity. Character are sorted in order of lower (up) to higher (down) SRD-RS correlation. 
Neurocranium showed only 6 correlations higher than 0.5 (out of 17). The highest values ( 0.69 and 0.77 for observed values) were found for the characters shared by both the Nasal and Oral modules, while the lowest significant values were distributed among the Base and Vault modules (Table 3.5).

Both t-tests and ANCOVAs on individual character flexibilities agrees that there is a significant increase of flexibility in characters from the Nasal, Oral and Vault modules, as well as a decrease of flexibility in characters from the Zygomatic, Vault and Base modules for canid species (Tables 3.6 and 3.7 and fig. 3.12C). Overall, the ANCOVA detects more decreases in flexibility on the Zygomatic, Vault and Base. For the character-specific $\bar{r}^{2}, \mathrm{t}$-tests detect only one increase in integration on the Nasal region and decreases throughout the skull modules (Table 3.6). The ANCOVAs of character-specific $\bar{r}^{2}$ on the other hand showed that integration increased throughout the skull, mainly in the Nasal and Oral modules (Table 3.7 and fig. 3.12D). Finally, both tests agrees that there is an increase in relative variance associated with the Facial region, while the Neurocranium shows a decrease in relative variance (Tables 3.6 and 3.7 and fig. 3.12E).

\section{Discussion}

\section{Similarity of G among Carnivora}

Here we conducted the most comprehensive analysis of the patterns of morphological integration of the skull in Carnivora so far. We included 144 species of almost all families currently recognized, producing the largest between species comparison of morphological integration in Mammals. The analysis of matrix similarity through Random Skewers (RS) showed that, despite not being identical, phenotipic matrices of covariance $\mathbf{P}$ showed high values of similarity (Figure C.2). These values were as high as the ones 

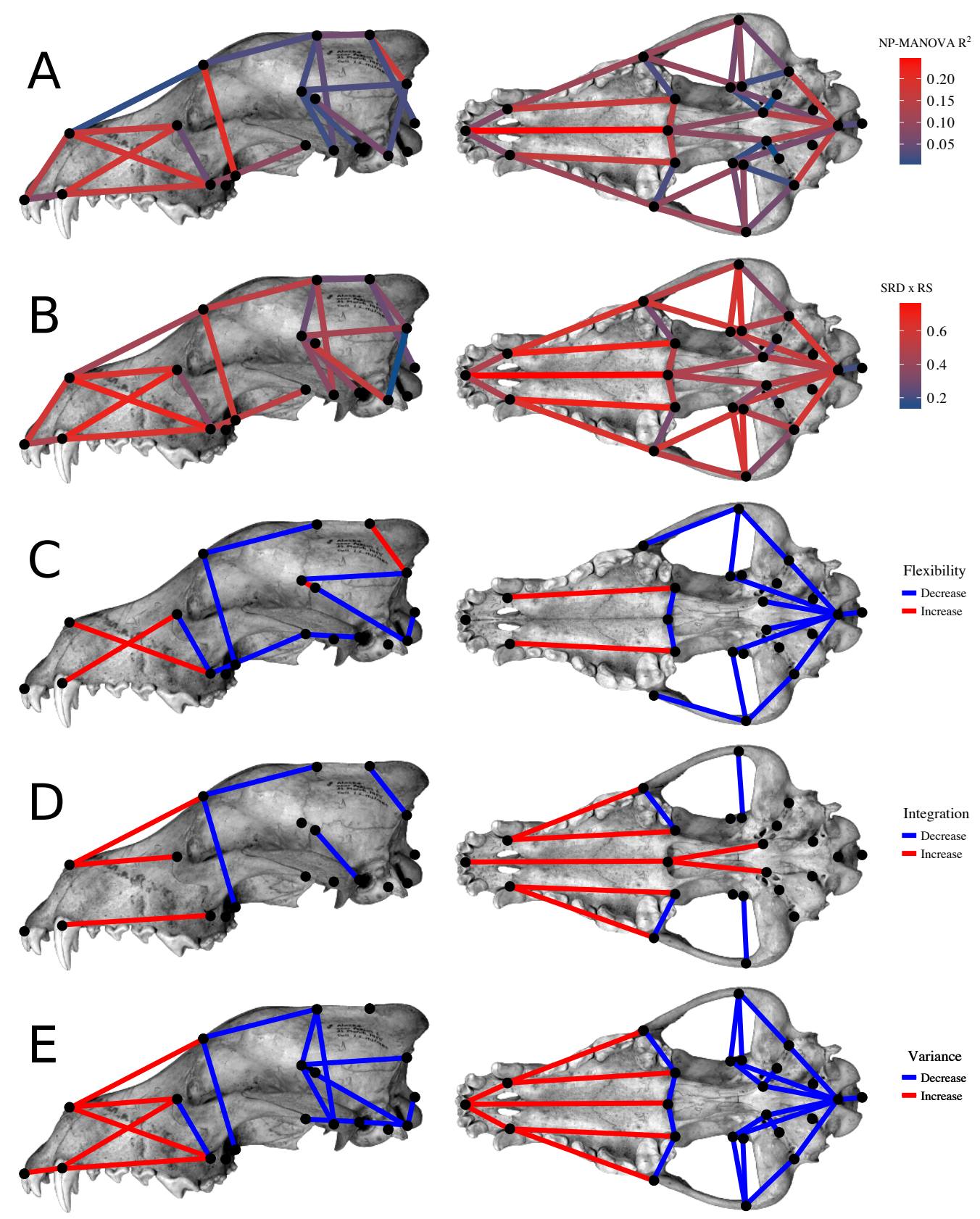

Figure 3.12: Graphical representation of the results from the character-based analysis represented on the skull of Canis lupus. A- Coefficient of determination $R^{2}$ of NP-MANOVAS between Canidae and the rest of Carnivora; B- Matrix correlation between SRD matrices and the RS matrix; C- Significant differences in character-specific flexibility; D- Significant differences in character-specific integration; E- Significant differences in character-specific relative variance. B-D refers to the significant differences found on the ANCOVA analysis using $\sqrt{r^{2}}$ as a covariate (see for full results Table 3.6). 
Table 3.5: Summary of RSxSRD matrix correlations and coefficient of determination $\left(R^{2}\right)$ for the NP-MANOVA between taxonomic groups (Canidae/Non-canid Carnivora). ${ }^{*} p<0.05 .{ }^{* *}-p<0.01$.

\begin{tabular}{|c|c|c|c|c|}
\hline Region & Module & Character & RSxSRD & $R^{2}$ \\
\hline Face & Nasal & IS-NSL & $0.604-0.570^{* *}$ & $0.143^{* *}$ \\
\hline Face & Nasal & NSL-NA & $0.430-0.401$ & 0.011 \\
\hline Face & Nasal & NSL-ZS & $0.618-0.591^{*}$ & $0.161^{* *}$ \\
\hline Face & Nasal & NA-PNS & $0.590-0.553^{*}$ & $0.202^{* *}$ \\
\hline Face & Oral/Nasal & IS-PNS & $0.774-0.753^{* *}$ & $0.245^{* *}$ \\
\hline Face & Oral/Nasal & NSL-ZI & $0.696-0.666^{* *}$ & $0.180^{* *}$ \\
\hline Face & Oral & IS-PM & $0.463-0.429$ & $0.077^{* *}$ \\
\hline Face & Oral & PM-ZS & $0.697-0.672^{* *}$ & $0.177^{* *}$ \\
\hline Face & Oral & PM-ZI & $0.633-0.596^{*}$ & $0.107^{* *}$ \\
\hline Face & Oral & PM-MT & $0.713-0.678^{* *}$ & $0.162^{* *}$ \\
\hline Face & Oral & ZI-MT & $0.300-0.273$ & $0.025^{*}$ \\
\hline Face & Oral & MT-PNS & $0.504-0.472$ & $0.143^{* *}$ \\
\hline Face & Oral/Zygomatic & ZS-ZI & $0.350-0.320$ & $0.051^{* *}$ \\
\hline Face & Zygomatic & PT-ZYGO & $0.606-0.573^{*}$ & $0.060^{* *}$ \\
\hline Face & Zygomatic & ZI-ZYGO & $0.522-0.489$ & $0.105^{* *}$ \\
\hline Face & Zygomatic & ZI-TSP & $0.599-0.556$ & $0.096^{* *}$ \\
\hline Face & Zygomatic & EAM-ZYGO & $0.338-0.298$ & $0.057^{* *}$ \\
\hline Face & Zygomatic & ZYGO-TSP & $0.637-0.603^{* *}$ & $0.090^{* *}$ \\
\hline Neurocranium & Vault/Zygomatic & PT-TSP & $0.244-0.226$ & $0.030^{*}$ \\
\hline Neurocranium & Vault & NA-BR & $0.518-0.502$ & $0.028^{*}$ \\
\hline Neurocranium & Vault & BR-PT & $0.269-0.238$ & $0.023^{*}$ \\
\hline Neurocranium & Vault & BR-APET & $0.471-0.424$ & $0.042^{* *}$ \\
\hline Neurocranium & Vault & PT-APET & $0.354-0.334$ & 0.012 \\
\hline Neurocranium & Vault & PT-BA & $0.546-0.518^{*}$ & $0.063^{* *}$ \\
\hline Neurocranium & Vault & PT-EAM & $0.495-0.471$ & 0.018 \\
\hline Neurocranium & Vault & LD-AS & $0.346-0.333$ & $0.167^{* *}$ \\
\hline Neurocranium & Vault & BR-LD & $0.278-0.291$ & $0.057^{* *}$ \\
\hline Neurocranium & Vault & OPI-LD & $0.266-0.238$ & 0.022 \\
\hline Neurocranium & Vault & PT-AS & $0.439-0.415$ & $0.025^{*}$ \\
\hline Neurocranium & Vault & JP-AS & $0.137-0.123$ & $0.025^{*}$ \\
\hline Neurocranium & Base & PNS-APET & $0.470-0.438$ & $0.086^{* *}$ \\
\hline Neurocranium & Base & APET-BA & $0.494-0.458^{*}$ & $0.136^{* *}$ \\
\hline Neurocranium & Base & APET-TS & $0.257-0.247$ & 0.001 \\
\hline Neurocranium & Base & BA-EAM & $0.607-0.577^{*}$ & $0.157^{* *}$ \\
\hline Neurocranium & Base & BA-OPI & $0.183-0.166$ & $0.034^{*}$ \\
\hline
\end{tabular}


Table 3.6: T-tests for the differences between Canidae and non-canid Carnivora for individual characters analyses. Flex.- Difference in characterspecific flexibility. $\bar{r}^{2}-$ Difference in mean character-specific integration. $\operatorname{Var}(\%)$ - Difference in the percentage of variation explained by character. Positive and negative values indicate increased or decreased values for Canidae respectively. ${ }^{*}-p<0.05$ without correction for multiple tests. ${ }^{*}{ }_{-}$ $p<0.05$ after correction for multiple tests (Bonferroni)

\begin{tabular}{|c|c|c|c|c|c|}
\hline Region & Module & Character & Flex. & $\sqrt{\overline{r^{2}}}$ & $\operatorname{Var}(\%)$ \\
\hline Face & Nasal & IS-NSL & -0.009 & $-0.045^{*}$ & $-0.007^{* *}$ \\
\hline Face & Nasal & NSL-NA & 0.006 & $0.086^{* *}$ & $0.039^{* *}$ \\
\hline Face & Nasal & NSL-ZS & $0.036^{* *}$ & $0.023^{*}$ & $0.019^{* *}$ \\
\hline Face & Nasal & NA-PNS & $-0.049^{* *}$ & $-0.044^{* *}$ & $-0.017^{* *}$ \\
\hline Face & Oral/Nasal & IS-PNS & $0.019^{*}$ & -0.010 & $0.010^{* *}$ \\
\hline Face & Oral/Nasal & NSL-ZI & $0.041^{* *}$ & -0.017 & $0.016^{* *}$ \\
\hline Face & Oral & IS-PM & $0.019 *$ & -0.019 & $0.001^{* *}$ \\
\hline Face & Oral & PM-ZS & $0.085^{* *}$ & -0.007 & $0.023^{* *}$ \\
\hline Face & Oral & PM-ZI & $0.029^{* *}$ & 0.003 & $0.016^{* *}$ \\
\hline Face & Oral & PM-MT & $0.049^{* *}$ & 0.003 & $0.019^{* *}$ \\
\hline Face & Oral & ZI-MT & 0.002 & $-0.090^{* *}$ & $-0.007^{* *}$ \\
\hline Face & Oral & MT-PNS & $-0.064^{* *}$ & $-0.064^{* *}$ & $-0.008^{* *}$ \\
\hline Face & Oral/Zygomatic & ZS-ZI & $-0.054^{*}$ & -0.013 & $-0.006^{* *}$ \\
\hline Face & Zygomatic & PT-ZYGO & -0.017 & $-0.042^{*}$ & $-0.010^{* *}$ \\
\hline Face & Zygomatic & ZI-ZYGO & -0.016 & -0.015 & $-0.006^{* *}$ \\
\hline Face & Zygomatic & ZI-TSP & 0.013 & $-0.042^{*}$ & -0.005 \\
\hline Face & Zygomatic & EAM-ZYGO & -0.025 & -0.031 & $-0.005^{* *}$ \\
\hline Face & Zygomatic & ZYGO-TSP & -0.001 & $-0.056^{* *}$ & $-0.009^{* *}$ \\
\hline Neurocranium & Vault/Zygomatic & PT-TSP & $0.157^{* *}$ & 0.001 & $0.015^{* *}$ \\
\hline Neurocranium & Vault & NA-BR & 0.001 & $-0.073^{*}$ & $-0.035^{* *}$ \\
\hline Neurocranium & Vault & BR-PT & 0.003 & $-0.040^{*}$ & $-0.006^{* *}$ \\
\hline Neurocranium & Vault & BR-APET & -0.008 & $-0.035^{*}$ & $-0.006^{* *}$ \\
\hline Neurocranium & Vault & PT-APET & 0.005 & -0.017 & $-0.002^{*}$ \\
\hline Neurocranium & Vault & PT-BA & -0.012 & $-0.027^{*}$ & $-0.007^{* *}$ \\
\hline Neurocranium & Vault & PT-EAM & 0.006 & -0.005 & -0.001 \\
\hline Neurocranium & Vault & LD-AS & $0.132^{* *}$ & $-0.101^{*}$ & 0.003 \\
\hline Neurocranium & Vault & BR-LD & 0.01 & -0.015 & -0.006 \\
\hline Neurocranium & Vault & OPI-LD & $0.084^{* *}$ & $-0.050^{*}$ & $0.006^{*}$ \\
\hline Neurocranium & Vault & PT-AS & -0.024 & -0.017 & $-0.008^{* *}$ \\
\hline Neurocranium & Vault & JP-AS & -0.028 & 0.025 & 0.001 \\
\hline Neurocranium & Base & PNS-APET & -0.007 & 0.013 & $0.005^{*}$ \\
\hline Neurocranium & Base & APET-BA & -0.023 & $-0.032^{*}$ & $-0.006^{* *}$ \\
\hline Neurocranium & Base & APET-TS & 0.014 & $-0.066^{* *}$ & $-0.002^{* *}$ \\
\hline Neurocranium & Base & BA-EAM & $-0.054^{* *}$ & $-0.041^{*}$ & $-0.011^{* *}$ \\
\hline Neurocranium & Base & BA-OPI & $-0.098^{* *}$ & 0.010 & $-0.003^{* *}$ \\
\hline
\end{tabular}


Table 3.7: ANCOVAs (with overall $\sqrt{r^{2}}$ as a covariate) for the differences between Canidae and non-canid Carnivora for individual characters. FlexDifference in character-specific flexibility. $\bar{r}^{2}$ - Difference in mean characterspecific integration. $\operatorname{Var}(\%)$ - Difference in the percentage of variation explained by character. Positive and negative values indicate increased or decreased values for Canidae respectively. ${ }^{*}-p<0.05$ without correction for multiple tests. ${ }^{* *}-p<0.05$ after correction for multiple tests (Bonferroni).

\begin{tabular}{|c|c|c|c|c|c|}
\hline Region & Module & Character & Flex & $\sqrt{r^{2}}$ & $\operatorname{Var}(\%)$ \\
\hline Face & Nasal & IS-NSL & -0.022 & $-0.022^{*}$ & -0.005 \\
\hline Face & Nasal & NSL-NA & $-0.036^{*}$ & $0.135^{* *}$ & $0.038^{* *}$ \\
\hline Face & Nasal & NSL-ZS & 0.019 & $0.059^{* *}$ & $0.019^{* *}$ \\
\hline Face & Nasal & NA-PNS & $-0.067^{* *}$ & $-0.027^{*}$ & $-0.016^{* *}$ \\
\hline Face & Oral/Nasal & IS-PNS & 0.006 & $0.017^{*}$ & $0.014^{* *}$ \\
\hline Face & Oral/Nasal & NSL-ZI & $0.024^{* *}$ & 0.009 & $0.017^{* *}$ \\
\hline Face & Oral & IS-PM & 0.006 & 0.010 & $0.002^{* *}$ \\
\hline Face & Oral & PM-ZS & $0.074^{* *}$ & $0.023^{*}$ & $0.025^{* *}$ \\
\hline Face & Oral & PM-ZI & 0.008 & $0.038^{* *}$ & $0.016^{* *}$ \\
\hline Face & Oral & PM-MT & $0.034^{* *}$ & $0.038^{* *}$ & $0.020^{* *}$ \\
\hline Face & Oral & ZI-MT & -0.024 & $-0.071^{* *}$ & $-0.007^{* *}$ \\
\hline Face & Oral & MT-PNS & $-0.086^{* *}$ & $-0.042^{*}$ & $-0.008^{* *}$ \\
\hline Face & Oral/Zygomatic & ZS-ZI & $-0.085^{* *}$ & 0.017 & $-0.007^{* *}$ \\
\hline Face & Zygomatic & PT-ZYGO & $-0.033^{* *}$ & $-0.023^{*}$ & $-0.009^{* *}$ \\
\hline Face & Zygomatic & ZI-ZYGO & $-0.043^{* *}$ & 0.017 & -0.005 \\
\hline Face & Zygomatic & ZI-TSP & -0.015 & -0.018 & -0.005 \\
\hline Face & Zygomatic & EAM-ZYGO & $-0.065^{* *}$ & 0.001 & $-0.006^{* *}$ \\
\hline Face & Zygomatic & ZYGO-TSP & -0.018 & $-0.040^{* *}$ & $-0.007^{* *}$ \\
\hline Neurocranium & Vault/Zygomatic & PT-TSP & $0.137^{* *}$ & 0.009 & $0.014^{* *}$ \\
\hline Neurocranium & Vault & NA-BR & $-0.041^{* *}$ & $-0.052^{* *}$ & $-0.039^{* *}$ \\
\hline Neurocranium & Vault & BR-PT & -0.030 & -0.018 & $-0.006^{* *}$ \\
\hline Neurocranium & Vault & BR-APET & $-0.031^{*}$ & -0.009 & $-0.005^{* *}$ \\
\hline Neurocranium & Vault & PT-APET & -0.017 & 0.000 & $-0.003^{* *}$ \\
\hline Neurocranium & Vault & PT-BA & $-0.033^{* *}$ & -0.005 & $-0.007^{* *}$ \\
\hline Neurocranium & Vault & PT-EAM & -0.021 & 0.018 & -0.002 \\
\hline Neurocranium & Vault & LD-AS & $0.099^{* *}$ & $-0.086^{* *}$ & 0.002 \\
\hline Neurocranium & Vault & BR-LD & -0.016 & -0.007 & $-0.010^{*}$ \\
\hline Neurocranium & Vault & OPI-LD & $0.049^{*}$ & $-0.028^{*}$ & $0.006^{*}$ \\
\hline Neurocranium & Vault & PT-AS & $-0.058^{* *}$ & 0.007 & $-0.01^{* *}$ \\
\hline Neurocranium & Vault & JP-AS & -0.052 & $0.043^{*}$ & 0.001 \\
\hline Neurocranium & Base & PNS-APET & $-0.039^{*}$ & $0.053^{* *}$ & $0.005^{*}$ \\
\hline Neurocranium & Base & APET-BA & $-0.044^{* *}$ & -0.009 & $-0.005^{* *}$ \\
\hline Neurocranium & Base & APET-TS & -0.007 & $-0.050^{*}$ & $-0.003^{* *}$ \\
\hline Neurocranium & Base & BA-EAM & $-0.067^{* *}$ & $-0.021^{*}$ & $-0.01^{* *}$ \\
\hline Neurocranium & Base & BA-OPI & $-0.124^{* *}$ & 0.026 & $-0.004^{* *}$ \\
\hline
\end{tabular}


observed among Old World Monkeys (Oliveira et al., 2009), Xenarthrans (Hubbe et al., 2016) and of Ruminants (Haber, 2014), but were lower on average than what was observed for New World Monkeys (Marroig and Cheverud, 2001). However, when we look at less inclusive taxa such as families, the average similarity goes up, being compared to that of New World Monkeys and within Ruminant families. In fact, the similarity among different families is compatible to that seen between both sub-orders of primates (Porto et al., 2009) and between Ruminant families (Haber, 2016), suggesting that patterns of morphological integration are as conserved within Carnivore as they are within other orders of mammals published so far.Modularity analysis reinforces this idea, showing that the modular patter of the skull is shared by all Carnivora (Table 3.3), reflecting the conclusion that a similar ontogonetic program is shared by all therian mammals (Goswami, 2006a; Porto et al., 2009).

Goswami (2006b) was the only previous study that formally evaluated the similarity in morphological integration of the skull between Carnivora species. That study found much higher similarities on average between species then those presented here, with values superior to 0.9 of analysis including size. While both studies shared many anatomical landmarks and had a similar number of traits (this study - 35 interlandmark distances; Goswami - 31 landmarks), they diverge mainly on morphometric techniques employed. While here we focused on the use of classically established measurements of cranial dimensions, Goswami (2006b) work was based on the a geometric morphometric representation of the data. The correlation matrix was obtained as the congruence coefficient between pairwise coordinates (Goswami and Polly, 2010), producing landmark-by-landmark matrices. While this can help explain the difference in similarity values (Klingenberg, 2008), the use of this landmark representation of morphometric data could be questioned. 
It is not entirely clear what kind of morphospace is being represented, nor how it can be analyzed through quantitative genetics means. For example, given that the selection gradient $\beta$ is a vector of partial regression coefficients of fitness onto traits (Lande and Arnold, 1983), how would a $\beta$ of individual landmarks be estimated, and what would it represent? Even though we can easily do that using other morphometric methods, including Procrustes data (Martínez-Abadías et al., 2012; Mitteroecker and Bookstein, 2011), the representation of data dependency through congruence coefficient and related methods still lacks clear connections with evolutionary theory. Therefore, the values found for (Goswami, 2006b) does not clearly translate into a quantitative genetics context. This does not mean that matrices of congruence coefficient between landmarks has no place in the investigation of morphological integration, though. A recent study showed that this type of matrix representation can be successfully used to investigate modularity (Goswami and Finarelli, 2016) reaching similar conclusions to analysis of both Procrustes coordinates and classical linear measurements (Cheverud, 1982). Additionally, preliminary analyses of the correlation between covariance matrix similarity and ecological factors has corroborated some of the conclusions presented by Goswami (2006b) for Feliformes (Zahn, 2016), showing that both approaches can reveal similar signals in the data. These analyses are currently being expanded to encompass all Carnivora.

In quantitative genetic terms, high levels of $\mathbf{P}$ similarity give us confidence that the underlying genetic covariance is most likely stable across species (Marroig and Cheverud, 2001). This is because, as previously explained, $\mathbf{P}$ is the sum of genetic $(\mathbf{G})$ and environmental $(\mathbf{E})$ covariances (Falconer et al., 1996) and, if Ps are similar, than that can be due to similarity in either G, E or in both. Given that G matrix for the characters analyses 
here seems to be conserved across mammalian Orders (Porto et al., 2009; Hubbe et al., 2016), it is more probable that similarity values found for Ps of Carnivora are due to a stable G. In fact, the similarity between Akodon (Cricetidae; Rodentia) G matrix and Canidae $\mathbf{P}$ matrix is as high as the average similarity observed within families, suggesting that we don't need to postulate any additional phenomena, other than $\mathrm{G}$ stability, to explain observed similarities. This does not exclude the possibility of the similarity being influenced by similar Es between species. However, because of morphological integration is an expression of ontogeny, $\mathbf{G}$ and $\mathbf{E}$ probably share similar structure, because both genetic and envirormental factors act on the same developmental pathways (Cheverud et al., 1983; Cheverud, 1988; Klingenberg, 2008). In other words, even if $\mathbf{E}$ is affecting $\mathbf{P}$ similarities, the fundamental cause is the conservation of ontogenetic pathways and, thus, of G.

According to quantitative genetic theory (Lande, 1980; Cheverud, 1984, 1996a), stability of $\mathbf{G}$ is possible when the amount of variation introduced by mutation is equivalent to the amount removed by selection. In that case

$$
\mathbf{G}=\mathbf{W}^{1 / 2}\left(\mathbf{W}^{-1 / 2} \mathbf{U} \mathbf{W}^{-1 / 2}\right)^{1 / 2} \mathbf{W}^{1 / 2}
$$

were $\mathbf{U}$ is the matrix of mutational effects and $\mathbf{W}$ is the matrix of the pattern of stabilizing selection on additive values. Because stabilizing selection is independent of directional selection (Lande, 1980; Cheverud, 1984), the mean phenotype can evolve while $\mathbf{W}$ remains the same, thus maintaining $\mathbf{G}$ stable.

Cheverud (1984) argued that W is a sum of both "external" (given by environmental and ecological factors) and "internal" stabilizing selection (given by internal coherence of ontogenetic pathways). If we consider only the diversity of feeding habits in Carnivora, the existence of a similar ex- 
ternal stabilizing selection on the skull across Carnivora would be rather remarkable. Carnivora includes durophagous bone-crakers (Hyena) and bambooeaters (Ailurus and Ailuropoda), pack-hunting hypercarnivores (e.g. Panthera leo, Lycaon pictus, Cuon alpinus, Speothos venaticus, Canis lupus), termitivores (Proteles cristata, Otocyon megalotis), large omnivores (Ursus), piscivores (e.g. Phoca, Pusa), filter feeders (Lobodon carcinophaga), suction feeders (e.g. Odobenus rosmarus) to name a few. Biomechanical studies have shown that even slight changes in feeding strategy can impose great stress on skulls (Slater et al., 2009; Slater and Van Valkenburgh, 2009), playing important roles in the evolution of carnivoran morphology (Slater et al., 2010; Tseng, 2013; Figueirido et al., 2013; Tseng and Flynn, 2015). Since biomechanical proprieties are functions of the relationship between variables, we would expect that those combinations of characters that optimize performance would be privileged by stabilizing natural selection (Rayner, 1985). Given that a broad range of feeding habits all converge to a similar covariance structure (implying similarity in stabilizing selection), one would have to conclude that biomechanical performance is not the main component of the stabilizing selection on the skull morphology of Carnivora. Then, if similar Ws exists, they would have to be influencing general aspects of the functionality of skull, such as the fit between lower mandible and cranium (Figueirido et al., 2013), or mainly be a product of internal stabilizing selection.

This is not to say that biomechanical factors do not affect the evolution of skull morphology in Carnivora, as they clearly do (e.g. Mattson, 1998; Sacco and Van Valkenburgh, 2004; Figueirido et al., 2009; Sicuro and Oliveira, 2010; Damasceno et al., 2013; Figueirido et al., 2011a; Werdelin and WesleyHunt, 2014; Kienle and Berta, 2015), but that ontogenetic constraints might then be playing a greater role in the structuring of within species variation (Cheverud, 1996a), influencing the evolution of complex morphologies. 


\section{Difference in Canidae}

The k-medoids cluster analysis performed on RS similarity values indicated that species of Canidae, despite being similar to other families, clustered separately, not only by responding differently to selection, but also by responding more similarly among each other (Figures C.2 and 3.6). Results obtained from observed and corrected values of RS differed in some aspects. While observed values produced a cluster with only Canidae, with the exception of a few species, the corrected values clustered all canid species together, along with a few representatives of other families. The only consistent result for observed and corrected values is that almost all Canidae clustered separately from almost all other Carnivora, with the exceptions being inconsistent among analysis. The NP-MANOVAs analysis pointed out that the differentiation of Canidae explains more variation in RS than the k-medoids cluster, a fact that was even more obvious for the corrected values (Table 3.1). The NP-MANOVAs also highlighted that corrected values of RS presents more variation than the observed ones (total Sum of Squares in Table 3.1), which might be explained by the fact that repeatabilities are estimated with error, even for high sample sizes (Figure 3.3). The introduction of an extra source of error increases variance, potentially making the discrimination of subtle differences in covariance structure more difficult (i.e. decrease in power).

The separation of Canidae from the rest of Carnivora could not be explained by differences in overall morphological integration $\left(\bar{r}^{2}\right)$, with the differentiation between Canidae and the rest of Carnivora explaining always more variation in matrix similarity than $\overline{r^{2}}$ (Table 3.2). The identification of taxa with different patterns of covariation is not in itself surprising. For an analysis within Catharrhini, (Oliveira et al., 2009) identified differences in Homo and Gorilla related to the increased modularity of 
the neurocranium (Porto et al., 2009). Shirai and Marroig (2010b) showed that Metachirus diverged from the rest of Didelphimorphia by having a low $\overline{r^{2}}$. For living Xenarthra, Hubbe et al. (2016) showed that Myrmecophaga responded differently to selection in relation to other species because some traits had larger variances and covariances. However, despite differences in single species or genus, studies showing differences between more inclusive taxa are rare. Haber (2014) was the only work to identify a distinction between two families (bovids and cervids), pointing to alterations in the correlation structure in the nasal and oral modules, mirroring findings presented here. However, variations in overall integration can influence individual correlations and modularity patterns (Porto et al., 2009 and Figures D.1 and D.2 here). Since both ruminant families also diverge in overall integration (Haber, 2016), its not clear if observed differences can be attributed to changes in overall integration alone. The use of ANCOVAs using $\bar{r}^{2}$ as a covariate allowed us to circumvent these issues and to dissect more clearly the nature of such differences. For this reason we focus on the discussion of ANCOVAs results bellow. Furthermore, by employing a taxonomicaly rich sample with 14 families and identifying changes in only one of them we reinforced both the ideas of conservation of covariance structure among Carnivora and differentiation only in Canidae.

It is unlikely that the results presented here are due to sampling differences. Our rarefaction analysis shows that the select sample is adequate to diagnose differences between families (Figure 3.4), and a correlation analysis between a matrix of pairwise geometric means of sample sizes and RS matrix revealed low value of correlation $(r=0.150)$, despite being significant. However, when we separate both sub-orders, Caniformes species showed no significant correlation $(r=0.097)$ while Feliformes show a higher significant correlation $(r=0.380)$. Despite this, the $\mathrm{k}$-medoids analysis showed 
no tendency to cluster species with similar samples, instead producing a taxonomicaly structured cluster around Canids.

Changes in Canidae covariance structure were not associated to shifts in overall morphological integration (as shown by the fact that $\bar{r}^{2}$ values for Canidae always falls within the range observed for the rest of Carnivora, Figures 3.8, 3.9, D.1 and D.2), but were associated with a decrease in overall flexibility after controlling for differences in $\overline{r^{2}}$ (Figure 3.9 and table 3.4). Even though $\bar{f}$ and integration are tightly negatively associated (Marroig et al., 2009; Goswami et al., 2014), the example of Canidae clearly shows that both can be decoupled by changes in patterns of integration (i.e. modularity, distribution of in variances and correlations, etc). This makes sense if we understand overall integration measures as they are: statistical summaries representing ensemble proprieties of matrices, such as averages of squared correlations (as presented here) or variances of eigenvalues (Wagner, 1984), for example. In both cases, different patterns of correlations among characters or of distribution of eigenvalues can map into the same statistic value ("many-to-one mapping"), possibly obfuscating subtle differences in covariance structure. While flexibility might also present similar many-to-one mapping pattern, our empirical result suggests that the cases were that happens might differ, even if slightly, for $\bar{r}^{2}$ and $\bar{f}$. This conclusion is in contrast to the one advanced by Haber (2016), who used simulations of randomly generated matrices and concluded that "the commonly observed tight inverse relationship between $r S D E(\mathbf{P})$ [relative Standard Deviation of Eigenvalues, a measure highly correlated with $\bar{r}^{2}$, Pavlicev et al., 2009; Haber, 2011] and $\bar{f}$ can be explained by their technical relationship, and does not in itself imply anything regarding the evolutionary implications of either" (Haber, 2016, Supplementary Online Material). Contrary to that however, the author also concluded that both $r \operatorname{SDE}(\mathbf{P})$ and $\bar{f}$ differed in their sensitivity to modular- 
ity, but dismissed this possibility as relevant, probably because parameters necessary for that effect to take place fell outside of the empirical parameter values under evaluation. Despite that, Haber (2016) results shows that more modular matrices will be slightly less flexible than less modular matrices with the same overall integration, as is the case for Canidae. Therefore we argue that these simulations and our empirical results actually shows the role of differences in pattern of morphological integration in shaping the evolutionary potential.

The K-medoids cluster analysis (Figure 3.11), NP-MANOVAS and matrix correlation with RS (Table 3.5) of individual selection response decomposition (SRD) matrices all point to the conclusion that Canidae differences are mainly concentrated in the Facial region (Figure 3.12A-B). ANCOVAs using $\overline{r^{2}}$ as covariate shows the Canidae is different by having more relative variance (as \% of total variance) on the Oral and Nasal modules while having less variation on the Zygomatic, Vault and Base (Table 3.3). These changes in relative variance are associated with significant increases in flexibility at the Nasal and decreases of flexibility at the Zygomatic and Base modules (Figure 3.9 and table 3.4). Additionally, analysis of modularity shows that the Nasal is more modular, having a higher AVG-ratio associated to an increase in the intra-module correlations (Figures 3.8, D.1 and D.2 and table 3.4). Individual character analysis largely reflects these results (Table 3.7), showing that increases in character variance are usually associated to increases in character flexibility (Figure 3.12C,D). Analysis of character-based integration also shows an increase in Nasal, Oral and Base characters and a decrease in the Vault and Zygomatic, despite affecting different traits than those highlighted by the analysis of the variance and flexibility (Figure 3.12D). The only characters that showed an increase in all three measures in Canidae were related to some general dimensions of the skull, namely palatal length 
(PM-MT), neurocranium height (PNS-NON), size of the parietal (BR-NON; Figure 3.12C-D). Jointly, these results lead us to the conclusion that Canidae has a more modular and flexible rostrum associated with an increase in variance and in morphological integration in traits related to the facial region, specifically to the Nasal and Oral modules.

The evolution of morphological integration on a quantitative genetic framework is a topic of intense debate and consensus on the causes of changes is still lacking (see Melo et al., 2016 for a recent review). Theoretical models have argued that both stabilizing (Lande, 1980) and directional selection (Pavlicev et al., 2011) can play an important part in changing the covariance pattern in G. Simulation analysis broadly confirm these expectations even under different models (Melo and Marroig, 2015; Jones et al., 2014). Specifically, Melo and Marroig (2015) model shows that, for a system with many traits, directional correlational selection on the same direction ("corridor selection") on a module and stabilizing selection on the rest of the traits increases not only intra-module correlation, but also increases the variation associated with directions that contrasts the selected and non-selected modules. This description matches what happens on the facial region of canids, specifically on the Nasal module. Additionally, the fact that RS similarities between Canidae and the other families is still high, despite these differences, reinforces the idea that the same stabilizing selection pattern is at play, at least for non facial modules. Thus, the combination of the same general stabilizing selection pattern of Carnivora plus a family-specific past history of direction selection on facial modules could explain differences observed in Canidae.

The causes for this selection on facial dimensions (mostly length) could be many. The relative length of the skull is tightly associated with changes in diet, mainly with carnivory. Canids with relative shorter snouts have an 
959

increased bite force (Damasceno et al., 2013) and mechanical performance for large prey capture (Slater et al., 2009), consistent with the fact that larger body size leads to increased levels of carnivory in Carnivora (Van Valkenburgh et al., 2004; Van Valkenburgh, 2007), via increase energetic demands (Carbone et al., 2007; Tucker et al., 2016). Canids also shows a positive allometric relationship between respiratory turbinal surface area and skull length, contrary to the isometric relationship observed for arctoid Carnivores (Green et al., 2012) and Feliformes (Van Valkenburgh et al., 2014), probably linked to the foraging necessities of hypercarnivores. Therefore, forces associated with dietary shifts in Canidae seems to be antagonistic in nature, probably imposing a more complex adaptive landscape on facial traits, leading to increase integration, variance and flexibility. 


\section{References}

Ackermann, R. R. and Cheverud, J. M. (2000). Phenotypic covariance structure in tamarins(genus Saguinus): a comparison of variation patterns using matrix correlation and common principal component analysis. American Journal of Physical Anthropology, 111(4):489-501.

Ackermann, R. R. and Cheverud, J. M. (2004). Detecting genetic drift versus selection in human evolution. Proceedings of the National Academy of Sciences of the United States of America, 101(52):17946-17951.

Agnarsson, I., Kuntner, M., and May-Collado, L. J. (2010). Dogs, cats, and kin: A molecular species-level phylogeny of Carnivora. Molecular Phylogenetics and Evolution, 54(3):726-745.

Agrawal, A. F. and Stinchcombe, J. R. (2009). How much do genetic covariances alter the rate of adaptation? Proceedings of the Royal Society of London. Series B, Biological Sciences, 276(1659):1183-1191.

Anderson, M. (2001). A new method for non-parametric multivariate analysis of variance. Austral Ecology, 26(1):32-46.

Arnold, C., Matthews, L. J., and Nunn, C. L. (2010). The 10kTrees website: A new online resource for primate phylogeny. Evolutionary Anthropology, 19(3):114-118.

Atchley, W. and Zhu, J. (1997). Developmental quantitative genetics, conditional epigenetic variability and growth in mice. Genetica, 147(2):765.

Berg, R. L. (1960). The ecological significance of correlation pleiades. Evolution, 14(2):171.

Bookstein, F. L. (1989). " Size and shape": a comment on semantics. Systematic Zoology, 38(2):173-180.

Caliński, T. and Harabasz, J. (1974). A dendrite method for cluster analysis. Communications in Statistic, 3(1):1-27.

Carbone, C., Teacher, A., and Rowcliffe, J. (2007). The costs of carnivory. PLoS Biology, 5(2):363-368.

Cheverud, J. M. (1982). Phenotypic, genetic, and environmental morphological integration in the cranium. Evolution, 36(3):499-516.

Cheverud, J. M. (1984). Quantitative genetics and developmental constraints on evolution by selection. Journal of Theoretical Biology, 110(2):155171.

Cheverud, J. M. (1988). A comparison of genetic and phenotypic correlations. Evolution, 42(5):958-968. 
Cheverud, J. M. (1995). Morphological integration in the saddle-back tamarin (Saguinus fuscicollis) cranium. The American Naturalist, 145(1):6389.

Cheverud, J. M. (1996a). Developmental integration and the evolution of pleiotropy. Integrative and Comparative Biology, 36:44-50.

Cheverud, J. M. (1996b). Quantitative genetic analysis of cranial morphology in the cotton-top (Saguinus oedipus) and saddle-back (S. fuscicollis) tamarins. Journal of Evolutionary Biology, 9(1):5-42.

Cheverud, J. M. and Marroig, G. (2007). Comparing covariance matrices: random skewers method compared to the common principal components model. Genetics and Molecular Biology, 30:461-469.

Cheverud, J. M., Rutledge, J., and Atchley, W. (1983). Quantitative genetics of development: genetic correlations among age-specific trait values and the evolution of ontogeny. Evolution, 37(5):895-905.

Christiansen, P. (2008). Evolutionary changes in craniomandibular shape in the great cats (Neofelis Griffith and Panthera Oken). Biological Journal of the Linnean Society, 95(4):766-778.

Cuvier, G. and Jameson, R. (1827). Essay on the Theory of the Earth. University of Michigan Library, Ann Arbor.

Damasceno, E. M., Hingst-Zaher, E., and Astúa, D. (2013). Bite force and encephalization in the Canidae (Mammalia: Carnivora). Journal of Zoology, 290(4):246-254.

Darwin, C. (1859). On the Origin of Species by Means of Natural Selection. John Murray, London.

Dayan, T., Wool, D., and Simberloff, D. (2002). Variation and covariation of skulls and teeth: modern carnivores and the interpretation of fossil mammals. 28(4):508-526.

Drake, A. G. and Klingenberg, C. P. (2010). Large-Scale Diversification of Skull Shape in Domestic Dogs: Disparity and Modularity. 175(3):289-300.

Falconer, D. S., Mackay, T. F., and Frankham, R. (1996). Introduction to quantitative genetics. Pearson Education Limited, Essex.

Figueirido, B., MacLeod, N., Krieger, J., Renzi, M. D., Perez-Claros, J., and PALMQVIST, P. (2011a). Constraint and adaptation in the evolution of carnivoran skull shape. Paleobiology, 37(3):490-518.

Figueirido, B., Palmqvist, P., and Pérez-Claros, J. A. (2009). Ecomorphological correlates of craniodental variation in bears and paleobiological implications for extinct taxa: an approach based on geometric morphometrics. Journal of Zoology, 277(1):70-80. 
Figueirido, B., Serrano-Alarcón, F. J., and Palmqvist, P. (2011b). Geometric morphometrics shows differences and similarities in skull shape between the red and giant pandas. Journal of Zoology, 286(4):293-302.

Figueirido, B., Serrano-Alarcón, F. J., Slater, G. J., and Palmqvist, P. (2010). Shape at the cross-roads: homoplasy and history in the evolution of the carnivoran skull towards herbivory. Journal of Evolutionary Biology, 23(12):2579-2594.

Figueirido, B., Tseng, Z. J., and Martín-Serra, A. (2013). Skull shape evolution in durophagous carnivorans. Evolution, 67(7):1975-1993.

Filzmoser, P., Garrett, R. G., and Reimann, C. (2005). Multivariate outlier detection in exploration geochemistry. Computers $\mathcal{E}$ Geosciences, 31(5):579587.

Fulton, T. L. and Strobeck, C. (2010). Multiple fossil calibrations, nuclear loci and mitochondrial genomes provide new insight into biogeography and divergence timing for true seals (Phocidae, Pinnipedia). Journal of Biogeography, 37:814-829.

Garcia, G. R. G., Hingst-Zaher, E., Cerqueira, R., and Marroig, G. (2014). Quantitative Genetics and Modularity in Cranial and Mandibular Morphology of Calomys expulsus. Evolutionary Biology, 41(4):619-636.

Garcia, G. R. G., Oliveira, F. B. d., and Marroig, G. (2015). Modularity and Morphometrics: Error Rates in Hypothesis Testing. bioRxiv, page 030874.

Gordon, A. D. and Vichi, M. (1998). Partitions of partitions. Journal of classification, 15(2):265-285.

Goswami, A. (2006a). Cranial modularity shifts during mammalian evolution. The American Naturalist, 168(2):270-280.

Goswami, A. (2006b). Morphological integration in the carnivoran skull. Evolution, 60(1):169-183.

Goswami, A. (2010). Introduction to carnivora. In Goswami, A. and Friscia, A., editors, Carnivoran Evolution. New views on phylogeny, form and function, pages 1-24. Cambridge University Press.

Goswami, A., Binder, W. J., Meachen, J. A., and O'Keefe, F. R. (2015). The fossil record of phenotypic integration and modularity: A deep-time perspective on developmental and evolutionary dynamics. Proceedings of the National Academy of Sciences of the United States of America, 112(16):48914896.

Goswami, A. and Finarelli, J. A. (2016). EMMLi: A maximum likelihood approach to the analysis of modularity. Evolution, 70(7):1622-1637. 
Goswami, A., Foley, L., and Weisbecker, V. (2013). Patterns and implications of extensive heterochrony in carnivoran cranial suture closure. Journal of Evolutionary Biology, 26(6):1294-1306.

Goswami, A. and Polly, P. D. (2010). Methods for studying morphological integration and modularity. Quantitative Methods in Paleobiology, 16:213243.

Goswami, A., Smaers, J. B., Soligo, C., and Polly, P. D. (2014). The macroevolutionary consequences of phenotypic integration: from development to deep time. Philosophical Transactions of the Royal Society B: Biological Sciences, 369(1649):20130254.

Grabowski, M. (2016). Bigger Brains Led to Bigger Bodies?: The Correlated Evolution of Human Brain and Body Size. Current Anthropology, 57(2):174-196.

Green, P. A., Van Valkenburgh, B., Pang, B., Bird, D., Rowe, T., and Curtis, A. (2012). Respiratory and olfactory turbinal size in canid and arctoid carnivorans. Journal of Anatomy, 221(6):609-621.

Haber, A. (2011). A Comparative Analysis of Integration Indices. Evolutionary Biology, 38(4):476-488.

Haber, A. (2014). The Evolution of Morphological Integration in the Ruminant Skull. Evolutionary Biology, 42(1):99-114.

Haber, A. (2016). Phenotypic Covariation and Morphological Diversification in the Ruminant Skull. The American Naturalist, 187(5):576-591.

Hall, B. K. (2005). Bones and cartilage: developmental and evolutionary skeletal biology. Elsevier Academic Press, San Diego, CA.

Hallgrímsson, B., Jamniczky, H., Young, N., Rolian, C., Parsons, T., Boughner, J., and Marcucio, R. S. (2009). Deciphering the palimpsest: studying the relationship between morphological integration and phenotypic covariation. Evolutionary Biology, 36(4):355-376.

Hallgrímsson, B., Lieberman, D., Young, N., Parsons, T., and Wat, S. (2007). Evolution of covariance in the mammalian skull. In Novartis Foundation Symposium, pages 164-190. John Wiley, Chichester; New York.

Hansen, T. (2006). The evolution of genetic architecture. Annual Review of Ecology, Evolution, and Systematics, 37(1):123-157.

Hansen, T. F. and Martins, E. (1996). Translating between microevolutionary process and macroevolutionary patterns: the correlation structure of interspecific data. Evolution, 50(4):1404-1417. 
Hartstone-Rose, A., Selvey, H., Villari, J. R., Atwell, M., and Schmidt, T. (2014). The Three-Dimensional Morphological Effects of Captivity. PLOS ONE, 9(11):e113437.

Helgen, K. M., Pinto, M., Kays, R., Helgen, L., Tsuchiya, M., Quinn, A., Wilson, D., and Maldonado, J. (2013). Taxonomic revision of the olingos (Bassaricyon), with description of a new species, the Olinguito. ZooKeys, 324:183.

Hernández-Romero, P. C., Guerrero, J. A., and Valdespino, C. (2015). Morphological variability of the cranium of Lontra longicaudis (Carnivora: Mustelidae): a morphometric and geographic analysis. Zoological Studies, 54(1):5-25.

Hervé, M. (2016). RVAideMemoire: Diverse Basic Statistical and Graphical Functions. $R$ package version 0.9-61.

Hlusko, L. J. and Mahaney, M. C. (2009). Quantitative Genetics, Pleiotropy, and Morphological Integration in the Dentition of Papio hamadryas. Evolutionary Biology, 36(1):5-18.

House, C. M. and Simmons, L. W. (2005). The evolution of male genitalia: patterns of genetic variation and covariation in the genital sclerites of the dung beetle Onthophagus taurus. Journal of Evolutionary Biology, 18(5):1281-1292.

Howell, P. E., Lundrigan, B., and Scribner, K. T. (2016). Environmental and genealogical effects on emergence of cranial morphometric variability in reintroduced American martens. Journal of Mammalogy, 97(3):761-773.

Hubbe, A., Melo, D., and Marroig, G. (2016). A case study of extant and extinct Xenarthra cranium covariance structure: implications and applications to paleontology. Paleobiology, 42(3):465-488.

Jolicoeur, P. (1959). Multivariate Geographical Variation in the Wolf Canis lupus L. Evolution, 13(3):283-299.

Jones, A. G., Bürger, R., and Arnold, S. J. (2014). Epistasis and natural selection shape the mutational architecture of complex traits. Nature Communications, 5:3709.

Jones, K. E. and Goswami, A. (2009). Quantitative analysis of the influences of phylogeny and ecology on phocid and otariid pinniped (Mammalia; Carnivora) cranial morphology. Journal of Zoology, 280(3):297-308.

Jones, K. E., Smaers, J. B., and Goswami, A. (2015). Impact of the terrestrialaquatic transition on disparity and rates of evolution in the carnivoran skull. BMC Evolutionary Biology, 15(8):1-19.

Kaufman, L. and Rousseeuw, P. (1987). Clustering by means of medoids. pages 1-12. 
Kienle, S. S. and Berta, A. (2015). The better to eat you with: the comparative feeding morphology of phocid seals (Pinnipedia, Phocidae). 228(3):396413.

Klingenberg, C. P. (2003). Quantitative genetics of geometric shape: heritability and the pitfalls of the univariate approach. Evolution, 57(1):191195.

Klingenberg, C. P. (2008). Morphological integration and developmental modularity. Annual Review of Ecology, Evolution, and Systematics, 39:115132.

Klingenberg, C. P. and Leamy, L. (2001). Quantitative genetics of geometric shape in the mouse mandible. Evolution, 55(11):2342-2352.

Lande, R. (1979). Quantitative genetic analysis of multivariate evolution, applied to brain: body size allometry. Evolution, 33(1):402-416.

Lande, R. (1980). The genetic covariance between characters maintained by pleiotropic mutations. Genetica, 94:203-215.

Lande, R. and Arnold, S. J. (1983). The measurement of selection on correlated characters. Evolution, 37(6):1210-1226.

Lessells, C. M. and Boag, P. T. (1987). Unrepeatable repeatabilities: a common mistake. The Auk, (104):116-121.

Linde, K. and Houle, D. (2009). Inferring the Nature of Allometry from Geometric Data. Evolutionary Biology, 36(3):311-322.

Lofsvold, D. (1986). Quantitative genetics of morphological differentiation in Peromyscus. I. Tests of the homogeneity of genetic covariance structure among species and subspecies. Evolution, 40(3):559-573.

Lofsvold, D. (1988). Quantitative genetics of morphological differentiation in Peromyscus. II. Analysis of selection and drift. Evolution, 42(1):54-67.

Lynch, M., Walsh, B., and others (1998). Genetics and analysis of quantitative traits, volume 1. Sinauer, Sunderland, MA.

Machado, F. A. and Hingst-Zaher, E. (2009). Investigating South American biogeographic history using patterns of skull shape variation on Cerdocyon thous (Mammalia: Canidae). Biological Journal of the Linnean Society, 98(1):77-84.

Marroig, G. and Cheverud, J. M. (2001). A comparison of phenotypic variation and covariation patterns and the role of phylogeny, ecology, and ontogeny during cranial evolution of New World monkeys. Evolution, 55(12):2576-2600. 
Marroig, G. and Cheverud, J. M. (2005). Size as a line of least evolutionary resistance: diet and adaptive morphological radiation in new world monkeys. Evolution, 59(5):1128-1142.

Marroig, G. and Cheverud, J. M. (2010). Size As A Line Of Least Resistance II: Direct Selection On Size Or Correlated Response Due To Constraints? Evolution, 64(5):1470-1488.

Marroig, G., Melo, D., Porto, A., Sebastião, H., and Garcia, G. R. G. (2011). Selection Response Decomposition (SRD): A New Tool for Dissecting Differences and Similarities Between Matrices. Evolutionary Biology, 38(2):225-241.

Marroig, G., Melo, D. A. R., and Garcia, G. R. G. (2012). Modularity, noise, and natural selection. Evolution, 66(5):1506-1524.

Marroig, G., Shirai, L. T., Porto, A., Oliveira, F. B. d., and Conto, V. (2009). The Evolution of Modularity in the Mammalian Skull II: Evolutionary Consequences. Evolutionary Biology, 36(1):136-148.

Marroig, G., Vivo, M., and Cheverud, J. M. (2004). Cranial evolution in sakis (Pithecia, Platyrrhini) II: evolutionary processes and morphological integration. Journal of Evolutionary Biology, 17(1):144-155.

Martinez, P. A., Marti, D. A., Molina, W. F., and Bidau, C. J. (2013). Bergmann's rule across the equator: a case study in Cerdocyon thous (Canidae). The Journal of animal ecology, 82(5):997-1008.

Martínez-Abadías, N., Esparza, M., Sjøvold, T., González-José, R., Santos, M., and Hernández, M. (2009). Heritability of human cranial dimensions: comparing the evolvability of different cranial regions. Journal of Anatomy, 214(1):19-35.

Martínez-Abadías, N., Esparza, M., Sjøvold, T., González-José, R., Santos, M., Hernández, M., and Klingenberg, C. P. (2012). Pervasive genetic integration directs the evolution of human skull shape. Evolution, 66(4):10101023.

Mattson, D. J. (1998). Diet and morphology of extant and recently extinct northern bears. Ursus, 10:479-496.

McArdle, B. and Anderson, M. (2001). Fitting multivariate models to community data: a comment on distance-based redundancy analysis. Ecology(Durham), 82(1):290-297.

McGuigan, K. (2006). Studying phenotypic evolution using multivariate quantitative genetics. Molecular Ecology, 15(4):883-896.

Meiri, S., Dayan, T., and Simberloff, D. (2005). Variability and correlations in carnivore crania and dentition. Functional Ecology, 19(2):337-343. 
Melo, D., Garcia, G. R. G., Hubbe, A., Assis, A. P., and Marroig, G. (2015). EvolQG - An R package for evolutionary quantitative genetics. F1000Research, 4(925):1-9.

Melo, D. and Marroig, G. (2015). Directional selection can drive the evolution of modularity in complex traits. Proceedings of the National Academy of Sciences of the United States of America, 112(2):470-475.

Melo, D., Porto, A., and Cheverud, J. M. (2016). Modularity: Genes, Development, and Evolution. Annual Review of Ecology, Evolution, and Systematics, 47:463-486.

Meloro, C., Clauss, M., and Raia, P. (2015). Ecomorphology of Carnivora challenges convergent evolution. Organisms Diversity $\mathcal{E}$ Evolution, 15(4):711-720.

Milenković, M., Šipetić, V. J., Blagojević, J., Tatović, S., and Vujošević, M. (2010). Skull variation in Dinaric-Balkan and Carpathian gray wolf populations revealed by geometric morphometric approaches. Journal of Mammalogy, 91(2):376-386.

Mitteroecker, P. and Bookstein, F. (2011). Linear Discrimination, Ordination, and the Visualization of Selection Gradients in Modern Morphometrics. Evolutionary Biology, 38(1):100-114.

Moss ML, Y. R. (1960). A functional approach to craniology. American Journal of Physical Anthropology, 18(4):281-292.

Nascimento, F. O. d. (2014). On the morphological variation and taxonomy of the Geoffroy's cat Leopardus geoffroyi (d'Orbigny \& Gervais, 1844) (Carnivora, Felidae). Papéis Avulsos de Zoologia (São Paulo), 54(11):129-160.

Nyakatura, K. and Bininda-Emonds, O. R. P. (2012). Updating the evolutionary history of Carnivora (Mammalia): a new species-level supertree complete with divergence time estimates. BMC Biology, 10(12):1-31.

Oliveira, F. B. d., Porto, A., and Marroig, G. (2009). Covariance structure in the skull of Catarrhini: a case of pattern stasis and magnitude evolution. Journal of Human Evolution, 56(4):417-430.

Olson, E. C. and Miller, R. L. (1958). Morphological integration. University of Chicago Press, Chicago and Longon.

Pavlicev, M., Cheverud, J. M., and Wagner, G. P. (2009). Measuring Morphological Integration Using Eigenvalue Variance. Evolutionary Biology, 36(1):157-170.

Pavlicev, M., Kenney-Hunt, J. P., Norgard, E. A., Roseman, C. C., Wolf, J. B., and Cheverud, J. M. (2008). Genetic variation in pleiotropy: differential epistasis as a source of variation in the allometric relationship between long bone lengths and body weight. Evolution, 62(1):199-213. 
Pavlicev, M., Norgard, E. A., Fawcett, G. L., and Cheverud, J. M. (2011). Evolution of pleiotropy: epistatic interaction pattern supports a mechanistic model underlying variation in genotype-phenotype map. Journal of Experimental Zoology Part B: Molecular and Developmental Evolution, 316B(5):371385.

Pearson, K. and Davin, A. G. (1924). On the biometric constants of the human skull. Biometrika, 16(3/4):328-363.

Pocock, R. I. (1935). The Races of Canis lupus. Proceedings of the Zoological Society of London, 105(3):647-686.

Poissant, J., Wilson, A. J., Festa-Bianchet, M., Hogg, J. T., and Coltman, D. W. (2008). Quantitative genetics and sex-specific selection on sexually dimorphic traits in bighorn sheep. Proceedings of the Royal Society of London. Series B, Biological Sciences, 275(1635):623-628.

Porto, A., Oliveira, F. B. d., Shirai, L. T., Conto, V., and Marroig, G. (2009). The Evolution of Modularity in the Mammalian Skull I: Morphological Integration Patterns and Magnitudes. Evolutionary Biology, 36(1):118-135.

Porto, A., Sebastião, H., Pavan, S. E., VandeBerg, J. L., Marroig, G., and Cheverud, J. M. (2015). Rate of evolutionary change in cranial morphology of the marsupial genus Monodelphisis constrained by the availability of additive genetic variation. Journal of Evolutionary Biology, 28(4):973-985.

Porto, A., Shirai, L. T., Oliveira, F. B. d., and Marroig, G. (2013). Size Variation, Growth Strategies, And The Evolution Of Modularity In The Mammalian Skull. Evolution, 67(11):3305-3322.

R Core Team (2016). R: A Language and Environment for Statistical Computing.

Radinsky, L. B. (1981a). Evolution of skull shape in carnivores: 1. Representative modern carnivores. Biological Journal of the Linnean Society, 15(4):369-388.

Radinsky, L. B. (1981b). Evolution of skull shape in carnivores: 2. Additional modern carnivores. Biological Journal of the Linnean Society, 16(4):337-355.

Radinsky, L. B. (1982). Evolution of skull shape in carnivores; 3, The origin and early radiation of the modern carnivore families. Paleobiology, 8(3):177-195.

Rayner, J. M. V. (1985). Linear relations in biomechanics: the statistics of scaling functions. Journal of Zoology, 206(3):415-439.

Revell, L. J. (2007). Testing the genetic constraint hypothesis in a phylogenetic context: a simulation study. Evolution, 61(11):2720-2727. 
Revell, L. J., Mahler, D. L., Sweeney, J. R., Sobotka, M., Fancher, V. E., and Losos, J. (2010). Nonlinear selection and the evolution of variances and covariances for continuous characters in an anole. Journal of Evolutionary Biology, 23(2):407-421.

Roff, D. A. (1995). The estimation of genetic correlations from phenotypic correlations: a test of Cheverud's conjecture. Heredity, 74:481-490.

Sacco, T. and Van Valkenburgh, B. (2004). Ecomorphological indicators of feeding behaviour in the bears (Carnivora: Ursidae). Journal of Zoology, 263(1):41-54.

Savell, K. R. R., Auerbach, B. M., and Roseman, C. C. (2016). Constraint, natural selection, and the evolution of human body form. Proceedings of the National Academy of Sciences of the United States of America, 113(34):94929497.

Schoch, R. R. (2006). Skull ontogeny: developmental patterns of fishes conserved across major tetrapod clades. Evolution and Development, 8(6):524536.

Schönemann, P. H. (1966). A generalized solution of the orthogonal Procrustes problem. Psychometrika, 31(1):1-10.

Schroeder, L., Roseman, C. C., Cheverud, J. M., and Ackermann, R. R. (2014). Characterizing the Evolutionary Path(s) to Early Homo. PLOS ONE, 9(12):e114307.

Shirai, L. T. and Marroig, G. (2010a). Skull modularity in neotropical marsupials and monkeys: size variation and evolutionary constraint and flexibility. Journal of Experimental Zoology Part B: Molecular and Developmental Evolution, 314B(8):663-683.

Shirai, L. T. and Marroig, G. (2010b). Skull modularity in neotropical marsupials and monkeys: size variation and evolutionary constraint and flexibility. Journal of Experimental Zoology Part B: Molecular and Developmental Evolution, 314(8):663-683.

Sicuro, F. L. and Oliveira, L. F. B. (2010). Skull morphology and functionality of extant Felidae (Mammalia: Carnivora): a phylogenetic and evolutionary perspective. Zoological Journal of the Linnean Society, 161(2):414-462.

Slater, G. J., Dumont, E. R., and Van Valkenburgh, B. (2009). Implications of predatory specialization for cranial form and function in canids. Journal of Zoology, 278(3):181-188.

Slater, G. J., Figueirido, B., Louis, L., Yang, P., and Van Valkenburgh, B. (2010). Biomechanical consequences of rapid evolution in the polar bear lineage. PLOS ONE, 5(11):e13870. 
Slater, G. J., Harmon, L. J., and Alfaro, M. E. (2012). Integrating fossils with molecular phylogenies improves inference of trait evolution . Evolution, 66(12):3931-3944.

Slater, G. J. and Van Valkenburgh, B. (2009). Allometry and performance: the evolution of skull form and function in felids. Journal of Evolutionary Biology, 22(11):2278-2287.

Steppan, S. J., Phillips, P. C., and Houle, D. (2002). Comparative quantitative genetics: evolution of the $\mathrm{G}$ matrix. Trends in ecology $\mathcal{E}$ evolution (Personal edition), 17(7):320-327.

Timm-Davis, L. L., Dewitt, T. J., and Marshall, C. D. (2015). Divergent Skull Morphology Supports Two Trophic Specializations in Otters (Lutrinae). PLOS ONE, 10(12):e0143236-18.

Torcida, S., Ivan Perez, S., and Gonzalez, P. N. (2013). An Integrated Approach for Landmark-Based Resistant Shape Analysis in 3D. Evolutionary Biology, 41(2):351-366.

Tseng, Z. J. (2013). Testing Adaptive Hypotheses of Convergence with Functional Landscapes: A Case Study of Bone-Cracking Hypercarnivores. PLOS ONE, 8(5):e65305.

Tseng, Z. J. and Flynn, J. J. (2015). An integrative method for testing formfunction linkages and reconstructed evolutionary pathways of masticatory specialization. Journal of The Royal Society Interface, 12(107):1-10.

Tseng, Z. J. and Wang, X. (2011). Do convergent ecomorphs evolve through convergent morphological pathways? Cranial shape evolution in fossil hyaenids and borophagine canids (Carnivora, Mammalia). Paleobiology, 37(3):470-489.

Tucker, M. A., Ord, T. J., and Rogers, T. L. (2016). Revisiting the cost of carnivory in mammals. Journal of Evolutionary Biology, 29(11):2181-2190.

Turelli, M. (1988). Phenotypic evolution, constant covariances, and the maintenance of additive variance. Evolution, 42(6):1342-1347.

Van Valkenburgh, B. (2007). Deja vu: the evolution of feeding morphologies in the Carnivora. American Zoologist, 47(1):147-163.

Van Valkenburgh, B., Pang, B., Bird, D., Curtis, A., Yee, K., Wysocki, C., and Craven, B. A. (2014). Respiratory and olfactory turbinals in feliform and caniform carnivorans: the influence of snout length. The Anatomical Record Part A: Discoveries in Molecular, Cellular, and Evolutionary Biology, 297(11):2065-2079.

Van Valkenburgh, B., Wang, X., and Damuth, J. (2004). Cope's Rule, Hypercarnivory, and Extinction in North American Canids. Science, 306:101-104. 
von Cramon-Taubadel, N., Frazier, B., and Lahr, M. (2007). The problem of assessing landmark error in geometric morphometrics: theory, methods, and modifications. American Journal of Physical Anthropology, 134:24-35.

Wagner, G. P. (1984). On the eigenvalue distribution of genetic and phenotypic dispersion matrices: evidence for a nonrandom organization of quantitative character variation. Journal of Mathematical Biology, 21(1):7795.

Wagner, G. P., Kenney-Hunt, J. P., Pavlicev, M., Peck, J., Waxman, D., and Cheverud, J. M. (2008). Pleiotropic scaling of gene effects and the 'cost of complexity'. Nature, 452(7186):470-472.

Wagner, G. P., Pavlicev, M., and Cheverud, J. M. (2007). The road to modularity. Nature Reviews Genetics, 8(12):921-931.

Walker, J. A. (2000). Ability of geometric morphometric methods to estimate a known covariance matrix. Systematic Biology, 49(4):686-696.

Werdelin, L. and Wesley-Hunt, G. D. (2014). Carnivoran ecomorphology: patterns below the family level. Annales Zoologici Fennici, 51:259-268.

Wilson, A. J., Pemberton, J. M., Pilkington, J. G., Clutton-Brock, T. H., Coltman, D. W., and Kruuk, L. E. B. (2007). Quantitative genetics of growth and cryptic evolution of body size in an island population. Evolutionary Biology, 21(3):337-356.

Wright, S. (1968). Evolution and the genetics of populations. Vol. 1. Genetic and biometric foundations. University of Chicago Press., London and Chicago.

Wroe, S. and Milne, N. (2007). Convergence and Remarkably Consistent Constraint in the Evolution of Carnivore Skull Shape. Evolution, 61(5):1251-1260.

Zahn, T. M. G. (2016). Integração morfológica no crânio e evolução da morfologia craniana em Feliformia (Carnivora: Mammalia). Master's thesis.

Zelditch, M. L., Swiderski, D. L., and Sheets, H. D. (2012). Geometric morphometrics for biologists: a primer. Academic Press.

Zuur, A. F., Ieno, E. N., and Elphick, C. S. (2010). A protocol for data exploration to avoid common statistical problems. Methods in Ecology and Evolution, 1:3-14. 
Chapter 4

Error rates of quantitative genetics tests applied to macroevolutionary

data 


\section{${ }_{10}$ Introduction}

11 The study of the causes of phenotypic diversification is one of the main which are common to whole groups of species, and which in truth are simply due to inheritance; for an ardent progenitor may have acquired through natural selection some one modification in structure, and, after thousands of generations, some other and independent modification; and these two modifications, having been transmitted to a whole group of descendants with diverse habits, would naturally be thought to be correlated in some necessary manner"

-Charles Darwin 1859, p. 133 ologists have sought to use the theory of natural selection to explain biological diversity on the planet (e.g. Fisher, 1930). Despite much interest, however, formal applications of theoretical evolutionary models to macroevolution were scarce for a long time. In a seminal paper, Gould and Lewontin (1979) strongly criticized the practices of biologists when it came to adaptive explanations. According to them, contemporary researchers were specially inclined to explain away any biological feature as the product of selection without addressing alternative hypothesis, such as drift and biological constraints (i.e. Maynard-Smith et al., 1985). The next decades were followed by an intense development of what is now referred as "Phylogenetic Comparative Methods", allowing for the test of a wide range of hypotheses about adaptive evolution in a macroevolutionary context, partly overcoming Gould and Lewontin's critique.

Even though some phylogenetic comparative methods do not have any

"We may often falsely attribute to correlation of growth, structures 
necessary association to explicit biological models (e.g. Giannini and Goloboff, 2010), the most influential ones are those based on quantitative genetics theories of continuous traits (Felsenstein, 1985; Hansen and Martins, 1996). Under these theories, traits are modeled as being influenced by a large number of alleles with infinitesimal genetic additive effects, allowing for the statistical modeling of evolutionary processes such as drift, stabilizing and directional selection. Despite the abundance of comparative methods, most of the implementations focus on univariate cases, and even though multivariate methods are slowly being developed (e.g. Felsenstein, 2008; King and Butler, 2009; Bartoszek et al., 2012; Goolsby et al., 2016), the majority of these methods ignore the effect of genetic correlations on evolutionary outcomes, another aspect of Gould and Lewontin's critique (Cheverud, 1984).

Russell Lande was the first to formally extend the quantitative genetic theory into a multivariate framework (Lande, 1979). In this context, phenotypic evolution is influenced not only by the available additive genetic variance, but also by the genetic covariance between characters, which are jointly expressed as a covariance matrix of additive effects called G. G is central for the evolution of complex phenotypic traits because it dictates how populations will behave under genetic drift and other evolutionary forces. According to Lande (1979) multivariate genetic drift is analogous to a random sampling of genetic additive effects and can be modeled as

$$
\mathbf{B}=\frac{t}{N_{e}} \mathbf{G}
$$

${ }_{3}$ where $\mathrm{B}$ is the covariance matrix of evolutionary changes $(\Delta \mathrm{zs}), t$ is the elapsed time since divergence from the ancestral population in generations and $N_{e}$ is the effective population size (Table 4.1). Given that $\frac{t}{N_{e}}$ is an unknown quantity in the vast majority of macroevolutionary studies, this expectation is translated into the investigation of the proportionality between 
B and G (Lofsvold, 1988; Ackermann and Cheverud, 2002, 2004; Marroig et al., 2004; Marroig and Cheverud, 2004). This concept is very powerful because, by modeling drift in a multivariate context, we can provide a nullexpectation of phenotypic evolution while incorporating genetic covariation between characters. We can then test if a given macroevolutionary pattern is sufficiently explained by drift+genetic constraints or if natural selection has to be invoked.

In the simplest case were all populations derive from the same ancestral group and there is no gene-flow among them, $\mathbf{B}$ will be identical to the covariance matrix among population means, or between-groups covariance matrix. This is because, since drift is modeled as a Gaussian random walk, the expectation is equal to the initial phenotype, making the average of the population means a good estimate of the ancestral trait value. The standard calculation of the covariance among population means will be based on the cross-product of the differences between species means and the ancestral phenotype (i.e. $\Delta \mathbf{z s})$.

For phylogenetically structured populations, Felsenstein (1985) showed that $\mathbf{B}$ will not be equal to the between-group covariance matrix because of the presence of correlation introduced due to phylogenetic non-independence (see also Hansen and Martins, 1996). In this case, Felsenstein argued that, if we have a tree with branch lengths proportional to the expected amount of evolution (Garland Jr et al., 1992; Garland, 1992), then B will be better estimated as the covariance matrix of Phylogenetic Independent Contrasts (PIC) of the original data (Felsenstein, 1988), or $\mathbf{B}_{P I C}$ (Table 4.1). If we assume that generation time, $N_{e}$ and $\mathbf{G}$ are constant though the phylogeny, then the magnitude of evolution will only depend on $t$ (in years), allowing for the use of a phylogeny with divergence times to estimate $\mathbf{B}_{\text {PIC }}$.

The objective of the present work is twofold. Firstly we call attention 
to this underappreciated theoretical framework for the study of multivariate phenotypic evolution. Secondly, we evaluate the statistical proprieties of two tests employed in the macroevolutionary studies under a quantitative genetics framework in order to provide guidance to researchers potentially interested in their application.

\section{Principal Component-Based Tests of Drift}

Ackermann and Cheverud (2002) first introduced two distinct methods to evaluate proportionality between $\mathbf{G}$ and $\mathbf{B}$ based on Principal Component Analysis (PCA). PCA is a common exploratory statistical tool and is based on the eigen-decomposition of a covariance matrix $\mathbf{A}$ as follows

$$
\mathbf{A}=\mathbf{V} \boldsymbol{\Lambda} \mathbf{V}^{-1}
$$

where $\mathbf{V}$ contains the standardized eigenvectors and $\Lambda$ is a diagonal matrix containing the eigenvalues of $\mathbf{A}$. For a square symmetrical matrix the eigenvectors, or Principal Components (PCs), are orthogonal to each other and can be interpreted as a new set of independent variables. The covariance matrix of these PCs is equal to $\Lambda$, and each eigenvalue is equivalent to the variance of each corresponding eigenvector. One can project the betweenspecies data $\mathbf{X}$ onto this new space as

$$
\mathbf{Y}=\mathbf{X V}
$$

The covariance matrix of $\mathbf{Y}$ is equivalent to $\mathbf{B}$ projected onto the $\mathbf{P C s}$, or $\mathbf{B}^{*}$. Alternatively $\mathbf{B}^{*}$ can be calculated by directly projecting $\mathbf{B}$ onto the PC space using Equation (4.2). If we premultiply by $\mathbf{V}^{-1}$ and postmultiply by $\mathbf{V}$, we can project a covariance matrix onto the space defined by $\mathbf{V}$. Given that the proportionality of $\mathbf{G}$ and $\mathbf{B}$ under neutral evolution is invariant to arbitrary 
Table 4.1: Glossary of symbols used and their corresponding description.

Symbol Description

G Genetic variance-covariance matrix.

B

Between-groups variance-covariance matrix. Covariance

B matrix of evolutionary changes $(\Delta \mathrm{zs})$ for independent populations.

Between-groups variance-covariance matrix estimated on

$\mathbf{B}_{\text {PIC }}$ phylogenetic independent contrasts. Covariance matrix of of evolutionary changes $(\Delta \mathrm{zs})$ for phylogenetically structured populations.

W Pooled within-groups covariance matrix used as an approximation of the ancestral G.

C Variance-covariance matrix of directional selection gradients $(\beta \mathrm{s})$.

$\mathbf{A}^{*} \quad *$ denotes projection of a variance-covariance matrix $\mathrm{A}$ on the principal components of $\mathbf{G}$.

$\mathbf{A}_{\text {cor }} \quad$ "cor" denotes a correlation matrix counterpart of a variance-covariance matrix $\mathbf{A}$.

$t \quad$ Time in generations.

Ne Effective population size.

$e \quad$ Effect size; the size of the directional selection vector $\mathbf{s}$ simulated. 
rotations of the phenotypic space (as long as both matrices are rotated by the same set of $\mathbf{V}$ ), the comparison of $\Lambda$ (or $\mathbf{G}^{*}$ ) and $\mathbf{B}^{*}$ is equivalent to the comparison between $\mathbf{G}$ and $\mathbf{B}$.

In order to develop a formal test of proportionality between matrices using PCA, Ackermann and Cheverud (2002) noticed that, by log-transforming Equation (4.1), we can write the comparison between $\mathbf{G}^{*}$ and $\mathbf{B}^{*}$ as a linear regression equation

$$
\log \left(\operatorname{var}\left(P C_{i}\right)\right)=a+b \log \left(\lambda_{i}\right)+\epsilon
$$

were $a=\log \left(\frac{t}{N_{e}}\right)$ is the intercept, $b$ is the slope, $\operatorname{var}\left(P C_{i}\right)$ are the variances of $\mathbf{B}^{*}, \lambda_{i}$ are the eigenvalues (variances) of $\mathbf{G}^{*}$ and $\epsilon$ is a gaussian error term. By using ordinary least-squares (OLS) regression analysis, one can adjust the values for the slope and compare it to the expected value under proportionality $b=1$. This can be achieved by either observing the parametric confidence interval of $b$ (Ackermann and Cheverud, 2002) or by applying a t-test to directly calculate p-values for the null hypothesis (Prôa et al., 2013).

Ackermann and Cheverud (2002) also argued that, since PCs are orthogonal to each other on G, under drift the same set of PCs should also be orthogonal on $\mathbf{B}$. This can be done by obtaining the correlation matrix of $\mathbf{Y}$ (Equation (4.3)) or, alternativally, by transforming $\mathbf{B}^{*}$ on its correlation counterpart $\mathbf{B}_{c o r}^{*}$. Because under the expectation of drift $\mathbf{B}^{*}$ is a diagonal matrix, its corresponding $\mathbf{B}_{c o r}^{*}$ is by definition an identity matrix $\mathbf{I}$ (i.e. no correlation between the species scores on the PCs of $\mathbf{G}$ ). Therefore, any deviation of $\mathbf{B}_{\text {cor }}$ from I can be seen as evidence to reject proportionality. This can be done by two main ways: firstly is the application of Bartlett $\chi^{2}$ which tests if a square matrix deviates from I and, secondly, by the presence of significant correlations between the projections of species means on the PCs of $\mathbf{G}$. This second test has the advantage of also providing information about the direction of 
selection (Marroig and Cheverud, 2004).

The use of these two methods -the regression approach and the correlation approach- in conjunction is convenient because they allow for the evaluation of different aspects of the covariance structure. While the regression focuses on the diagonal of $\mathbf{G}^{*}$, the correlation test investigates the offdiagonal elements of this matrix, constituting two lines of evidence to test the hypothesis of neutral evolution.

Type I error (false positives) rates for the regression test were previously explored in two papers (Ackermann and Cheverud, 2002; Prôa et al., 2013), but type II error rates (false negatives) or power (rate of rejection of a false null-hypothesis, or 1-(type II error rate)) were previously discussed (Ackermann and Cheverud, 2002), but not systematically investigated. In the present contribution we calculate type I error rate and power of both regression and correlation tests of neutral evolution of multivariate quantitative characters on phylogenetically structured populations. We employed quantitative genetic theory in order to simulate phenotypic evolution by drift and natural selection on a phylogeny. Because species are phylogenetically related, we expect that analysis using phylogenetic comparative methods will outperform analysis on raw data, at least for the correlation test. Because variances are not affected by phylogenetic relationships, we expect that the regression test will be more consistent between phylogenetic and non-phylogenetic approaches.

As a case study we use Caniformes (Carnivora) skull morphological evolution. Caniforms are a diverse group of mammals, containing 9 families ( 2 of which are monospecific) and more than 160 species, allowing for the examination of a range of species sample sizes. Additionally, caniforms phylogenetic relationships between species are fairly well known (Arnold et al., 2010; Agnarsson et al., 2010; Nyakatura and Bininda-Emonds, 2012; 
Slater et al., 2012), providing a robust framework for simulation analysis.

Finally, cranial morphology and evolution has been intensively studied for this group and is generally agreed that morphological diversity is influenced by ecological factors, mainly feeding ecology (e.g. Wroe and Milne, 2007; Jones and Goswami, 2009; Figueirido et al., 2010; Slater et al., 2009, 2010; Tseng and Wang, 2011; Figueirido et al., 2011b, 2013). Most studies, however, do not take into account the role of genetic constraints nor explicitly test the null hypothesis of drift. Here we test the null hypothesis of drift for these groups.

\section{Materials and Methods}

\section{Sample, measurements and matrices}

The caniform phylogeny was obtained from Slater et al. (2012). High-level phylogenetic relationship seems robust and concordant with most published phylogenies (Arnold et al., 2010; Fulton and Strobeck, 2010; Slater et al., 2012; Agnarsson et al., 2010; Nyakatura and Bininda-Emonds, 2012). We manually added newly described species to the tree topology in order to maximize species sample (Figure 4.1, see Appendix E for details about modifications).

We obtained 35 cranial measurements from 5088 individuals as distances between anatomical landmarks. The effects of confounding factors such as sex or subspecies were removed from the sample using a multivariate linear model. Pooled within-group covariance matrices $\mathbf{W}$ for cranial traits were estimated for each node of the phylogeny by pooling the residuals of all daughter species and adjusting for lost of degrees of freedom due to the removal of within and between species effects. The taxonomy used and sample sizes can be seen on Table E.1. Details about sample, data processing, 

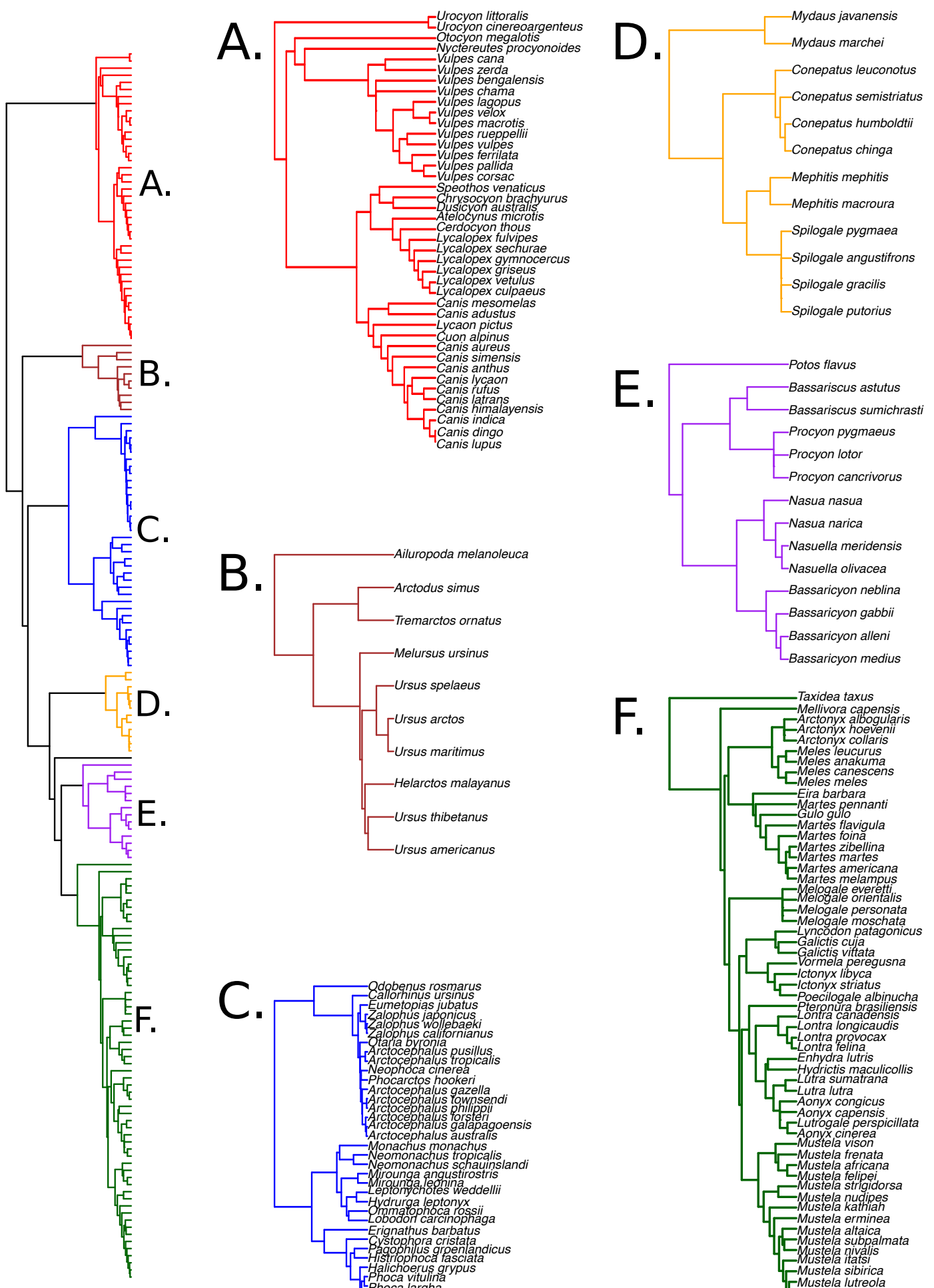

F.

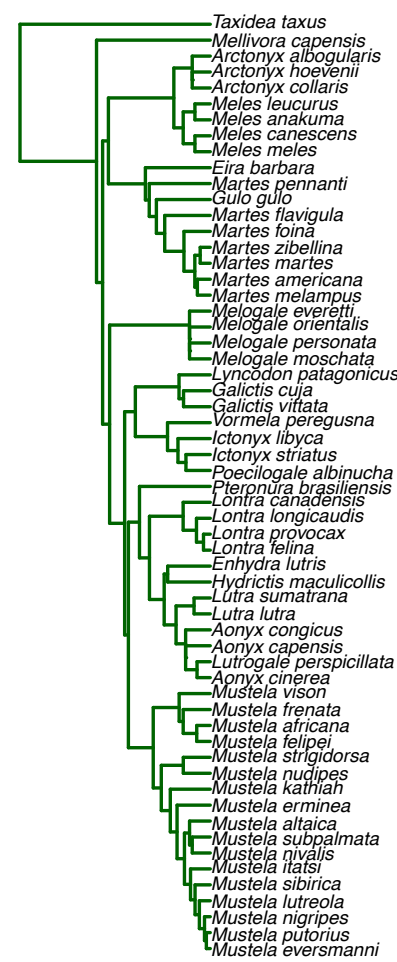

Figure 4.1: Caniform Phylogeny modified from Slater et al. (2012). ACanidae; B- Ursidae; C- Pinipedia; D- Mephitidae; E- Procyonidae; FMustelidae. 
measurements and estimation of $\mathbf{W}$ s can be found in Chapters 2 and 3.

Given that covariance matrices were considered highly similar among Carnivora species (Chapter 3), W matrices can be confidently used as substitutes for $\mathrm{G}$ in order to model phenotypic evolution and to investigate the mode of evolution on our empirical example (Cheverud, 1982, 1996; Ackermann and Cheverud, 2000; Cheverud et al., 1983; Marroig and Cheverud, 2001; Oliveira et al., 2009; Hubbe et al., 2016). Because $\mathbf{W}$ are estimates with sampling error, matrices were controlled for noise according to Marroig et al. (2012), by first investigating the Second-derivative variance of the eigenvalues of each $\mathbf{W}$ matrix. When this values stabilizes near zero, the eigenvalue of the following eigenvectors is raised (extended) to the value of the stable eigenvector. This is done in order to minimize the effect of small eigenvalues on the inverted matrix. Extended versions of the $\mathbf{W}$ matrices were only used when matrix inversion was necessary.

\section{Model of phenotypic evolution}

Phenotipic evolution was modeled by incorporating both natural selection and drift as

$$
\mathbf{B}=t\left(e \mathbf{G} \mathbf{G}+\frac{\mathbf{G}}{N_{e}}\right)
$$

were $t$ and $N_{e}$ are the time in generations and the effective population size, as in Equation (4.1), $\mathbf{G}$ is the genetic covariance matrix, $\mathbf{C}$ is the covariance matrix of selection gradients and $\mathbf{B}$ here is the matrix of covariance of evolutionary responses $\Delta$ zs (Lande, 1979; Felsenstein, 1988; Zeng, 1988; Hansen and Martins, 1996; Arnold et al., 2001). $e$ is the effect size controlling the relative importance (intensity) of natural selection (GCG) in relation to drift ( $\mathrm{G} / N_{e}$; see Table 4.1 for a glossary of the terms of the model). 
$\mathbf{C}$ was modeled as $\mathbf{s}^{t} \mathbf{s}+\mathbf{I} / 1000$, were $s$ is a random vector of norm $=1$ ( ${ }^{t}$ denotes transpose) and $\mathbf{I}$ is an identity matrix. This last step was added to ensure that $\mathbf{C}$ was positive-definite. Since for $e=1$ we want selection and drift to have the same relative importance, both GCG and G/ $N_{e}$ were scaled to have the same trace. However, by altering $e$, CGC can be arbitrarily big or small in relation to $\mathrm{G} / N_{e}$. If $e$ tends to zero, than is easy to see that Equation (4.5) collapses into Equation (4.1). Thus, we are able to alter not only the intensity of directional selection, but the mode of evolution, by adjusting only the parameter $e$. In addition to simulating species means we also performed a Monte Carlo sampling of within-species variation to evaluate the impact of sampling on both mean species phenotype and on the estimation of $\mathbf{W}$ (following Prôa et al., 2013). A detailed description of the model and the R code used to implement it can be found at Appendix E. All analysis were done on the $\mathrm{R}$ programming environment (R Core Team, 2016).

To observe the impact of variation in species sample size on type I error and power, the simulations were conducted on each clade of the phylogeny. For each node we estimated $\mathbf{W}$ (see Chapter 4 ) and extracted the phylogeny of that particular clade. We restricted the analysis to nodes that had a pooled sample larger than 35 and that had more than the minimum proposed sample of 4 species (Ackermann and Cheverud, 2002), resulting in a total of 91 clades from various taxonomic ranks. The Table E.2 shows the summary of the number of simulations performed for each analysis described bellow.

We also performed all analysis on sets of randomly selected species (and trees) following Cressler et al. (2015), but since preliminary results for type I error and power were basically the same, we only report the clade-based analysis for clarity. Because there is a strong correlation between pooled within-group sample size (i.e. sample used to estimate $\mathbf{W}$ ) and number of 
species $(r=0.93)$ we only display results in relation to species sample size.

\section{Type I error rates and Power}

Simulations were performed using eight values for $e=[0,0.001,0.01,0.1,1$, $10,100,1000]$. As stated above, when $e=0$ the simulation is equivalent to neutral evolution, while for all other values of $e$ the relative contribution of GCG varies exponentially. For each run both the regression and the correlation tests were conducted. For the regression test, the deviation of the estimated slope from 1 was accessed through a t-test. For the correlation tests each pairwise correlation of $\mathbf{B}_{c o r}^{*}$ was subjected to a significance test and the resulting p-values were corrected for multiple comparisons using the Bonferroni correction. The null-hypothesis was rejected if the matrix showed any significant correlation. In cases were species $n$ was smaller than the number of variables, we performed the analysis by evaluating the correlation among only the first $n$ PCs (Marroig and Cheverud, 2004).

For each run, the tests were done in four different ways. Firstly, all tests were conducted using raw untransformed data and on PIC estimated for the clade under analysis. For PIC, all the operations were performed by simply substituting $\mathbf{B}$ by $\mathbf{B}_{\text {PIC }}$ where needed (Revell, 2007). Secondly, for both raw and PIC data, tests were performed by using the original $\mathbf{W}$ or by using the resampled $\mathbf{W}$ for each run of the simulation. This was done in order to inspect the impact of sampling of $\mathbf{W}$ on the test results.

For all values of $e$, the rate of rejection of the null hypothesis was calculated. For $e=0$, the rate is equal to the type I error rate, while for non-zero values of $e$ the rate equals to the Power of the test. The simulations were run for each clade-e combination.

Since the PCs are sorted according to their eigenvalues, it is easy to remove axis that explain smaller proportion of the total variation. For multi- 
variate morphometrics this can be specially useful because the reduction of the number of variables can lead to a better estimation of statistical parameters, specially in the case of covariance and correlation matrices (Friedman, 1989). Additionally, the last eigenvalues of a covariance matrix are thought to be associated with noise (Marroig et al., 2012), and their removal is sometimes proposed as a way to improve statistical inferences (Strauss, 2010; Mitteroecker and Bookstein, 2011). To assess if the reduction of the dimensionality of the data affects statistical proprieties of the neutral evolution tests, we remove the last 5, 10, 15, 20, 25 and 30 PCs, and calculated error I rate and power for clades with small sample size (5-6 species).

\section{Variation in $N_{e}$}

One of the underling assumptions of the use of the quantitative genetic model for drift (Equation (4.1)) is that effective population size $N_{e}$ have to be constant throughout the evolutionary history of the group. However, its highly unlikely that this will hold for large evolutionary scales, with some groups showing abrupt differences in $N_{e}$ between sister taxa or even along the history of a species. Calculations of $N_{e}$ are generally not available for all species within a large groups and even if that was the case, estimation of ancestral $N_{e}$ along all phylogeny are not trivial, even if possible.

To evaluate the potential effects of variation in $N_{e}$ on the statistical performance of the tests we artificially altered the branch lengths of the phylogeny, as to simulate increase or decrease of rates of neutral evolution along that tree (Venditti et al., 2011; Baker et al., 2016). In practice, since the neutral simulations are based on multiplying draws from $\mathbf{G}$ by the branch length as a representation of $t / N_{e}$ (see Appendix E), artificially increasing (or decreasing) branch lengths can be interpreted as a proportional decrease (or increase) in $N_{e}$. 
For each run of the simulation a number of scalars equals to the number of branches were drawn from a normal distribution with mean 0 and five different values for standard deviation $(\sigma=[0.1,0.7,1.3,1.9,2.5])$. The exponential of each scalar was obtained and then multiplied by the branch length to simulate an alteration in the rate of drift following Equation (4.1). This produced a range of scenarios were the $N_{e}$ was rather stable on one side $(\sigma=0.1,95 \%$ range of scalars:0.822 -1.217$)$ and variable on the other $\left(\sigma=2.5,95 \%\right.$ range of scalars:0.007 -134.390). If we assume baseline $N_{e}$ of 20000 , than the simulations can be seen as varying $N_{e}$ from $16440-24331$ on one extreme $(\sigma=0.1)$ and $149-2685796$ on the other $(\sigma=2.5)$. Type I error rates were calculated as described above. The PIC version of the regression and correlation tests used to access type I error rates were performed on the original unscaled phylogeny.

\section{Empirical example: Caniform Families}

To evaluate the performance of the tests on a empirical datasets we performed both regression and correlation tests for neutral evolution on the 7 non-monospecific Caniform Families: Canidae, Ursidae, Otariidae, Phocidae, Mephitidae, Procyonidae and Mustelidae. Polled sample size was on average 173, full sample size ranged from 463-2350 and species sample size ranged from 8-57 among families (Table E.1).

Drift tests were performed on raw and PIC data and significance was accessed by both parametric tests and simulations. For parametric correlation tests we used the full dataset and also a reduced number of PCs (always less PCs than the number of species, as for Ackermann and Cheverud, 2004; Marroig and Cheverud, 2004), always controlling for multiple correlations using Bonferroni. Regression analysis was performed using OLS regression and differences of the estimated slope from 1 (the null-expectation) were 
tested through t-tests.

For non-parametric tests, the simulations previously described for neutral evolution (with sampling error on $W$ ) were used to construct null distributions based on the family-level phylogeny and $\mathrm{W}$ matrix. For each family 10000 simulations were conducted and all the statistics were calculated at each run. Empirical values were considered significant if they fell outside 95\% intervals calculated from simulations.

For the correlation analysis a multiple test correction should be employed. However, if we apply Bonferroni on empirical p-values obtained through 10000 simulations, the lowest corrected value would be insufficient to reject the null hypothesis at $\alpha=0.05$ for all cases (minimum corrected $p-$ value $=0.0595)$. For that reason, we also recorded the correlation values that fell completely outside the simulated empirical distribution (i.e. when $\mathrm{p}>0.0001)$.

\section{Results}

\section{Type I error and Power}

For the analysis of raw data, the type I error rate (false positives) for the regression test of neutral evolution was greatly impacted by the resampling of $\mathbf{W}$ through Monte-Carlo (Figure 4.2, upper left panel). When we assumed that $\mathbf{G}$ was estimated without error (no resampling), type I error rates were nominal $(\alpha=0.05)$ independent of sample size. However if we account for sampling error through Monte-Carlo resampling of $\mathbf{W}$, error rates were greatly inflated, mainly for samples lower than 10, were the median error rate was of 0.21 , with values as high as 0.98 . Correlation tests, on the other hand, showed inappropriate type I error rates independent of sampling error on $\mathbf{W}$, showing small error rates at lower species samples $(<6)$ that 
quickly escalates to 1.00 error rates at $n \approx 15$ (Figure 4.2, lower left panel).

For the analysis of phylogenetic independent contrasts (PIC) data type I error rates for the regression tests also showed nominal values for all samples sizes when within-group sampling was not accounted for. However, when within-group error was introduced, values were slightly inflated, with a median error of 0.9 for small sample sizes $(n<10)$, reaching values as high as 0.48 (Figure 4.2, upper right panel). For correlation tests on PIC data, both with and without sampling error on $\mathbf{W}$ showed nominal error rates throughout all sample sizes (Figure 4.2, lower right panel).

Sampling error on $\mathbf{W}$ seems to affect mainly the power of regression analysis, being higher when the resampling of $\mathbf{W}$ was not performed (Figure 4.3, first and second columns). Bellow I describe mainly the results for the simulations with sampling error.

For the lowest values of the effect size $e(0.001-0.1)$ the rates of rejection of the null hypothesis (power) were virtually indistinguishable from the simulations without directional selection (Figure 4.3, first row). For $e=1$, both regression and correlation tests on PICs behave similarly, with an almost linear increase in power with the increase of $n$ (Figure 4.3 , middle row). The regression test on raw data shows a similar but more moderate increase in power with sample size for the same effect size. For $e=10$, regression tests on PIC data shows power $=1.00$ at $n=20$, while analysis on raw data fails to reach that value for $n<40$. Correlation analysis on raw data reaches power $=1.00$ at $n=15$, while this analysis on PIC also fails to reach power $=1.00$ for $n<40$ (Figure 4.3, forth row). For higher values of $e$ (100-1000) regression tests shows a rapid increase in power, with raw data reaching power $=1.00$ at sample sizes closer to 20 , while PIC data reaches the same asymptote at samples closer to 15 . For correlation tests, power $=1.00$ is reached at $n=5$ (Figure 4.3 , last two rows), with values for $n=4$. being 


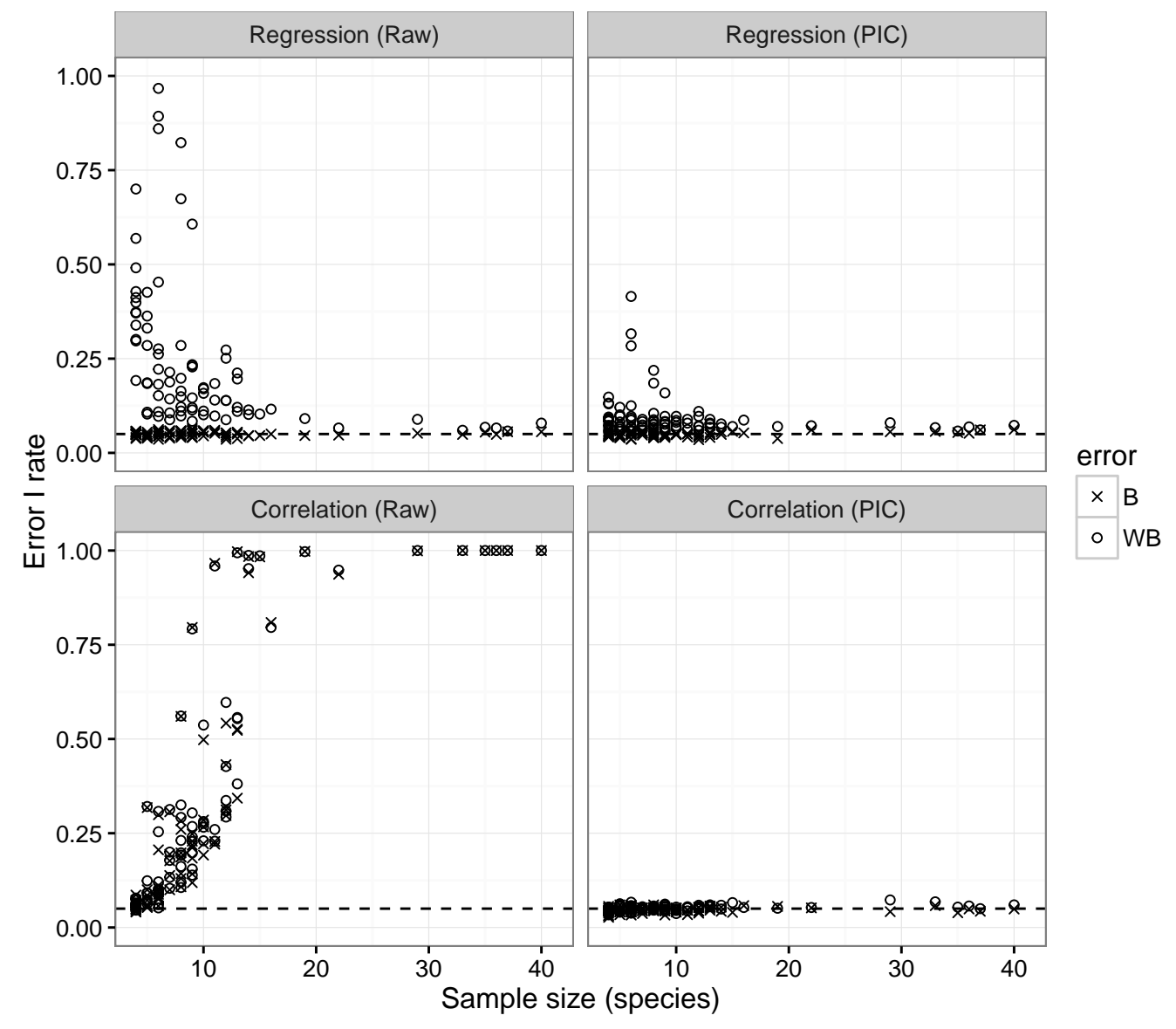

Figure 4.2: Type I error rates for regression and correlation tests of drift on raw and PIC data. B- Analysis without resampling of W. WB-Analysis with resampling of $\mathrm{W}$. 
higher for raw data than for PIC data.

Because power was close to 0.05 in all tests (with exception of correlation analysis on raw data) for $e \leq 1$, the effect of variation of the number of PCs on power was only evaluated for effect sizes larger than $e=1$. For those cases, differences in PC numbers impacted power similarly, the only difference being the baseline power for the full set of vectors. Thus, here we focus on the results for $e=1000$, were the effects of the reduction of dimensionality are clearly illustrated (Figure 4.4).

Both type I error rates and power for all analysis were effected by the reduction of the number of PCs, with the exception of the type I error of the correlation analysis on PIC data, that showed nominal values $(\alpha=0.05)$ in all simulations (Figure 4.4). Analogously, correlation analysis of raw data also showed no difference in type I error rates, but all values were superior to the nominal value. For regression analysis, the decrease in the number of PCs allowed for the reduction of type I errors for both raw and PIC data. For PIC analysis, nominal levels were reached with PCs=20, while for raw data, nominal levels were reached only with $P C=10$. Regarding power, both regression analysis (PIC and Raw data) showed an increase in power as more PCs were retained, with the exception that analysis on PIC tended to show superior values for simulations accounting for sampling error. Correlation analysis showed high power for low number of PCs retained, and showed a decrease in power as more PCs were retained. This pattern was more pronounced for PIC then for raw data.

\section{Variation in $N_{e}$}

Variation in $N_{e}$ had no discernible effect on the regression analysis performed on either raw data or PIC data for all levels of $\sigma$ Figure 4.5. For correlation analysis the increase in the variation of $N_{e}$ along the phylogeny 


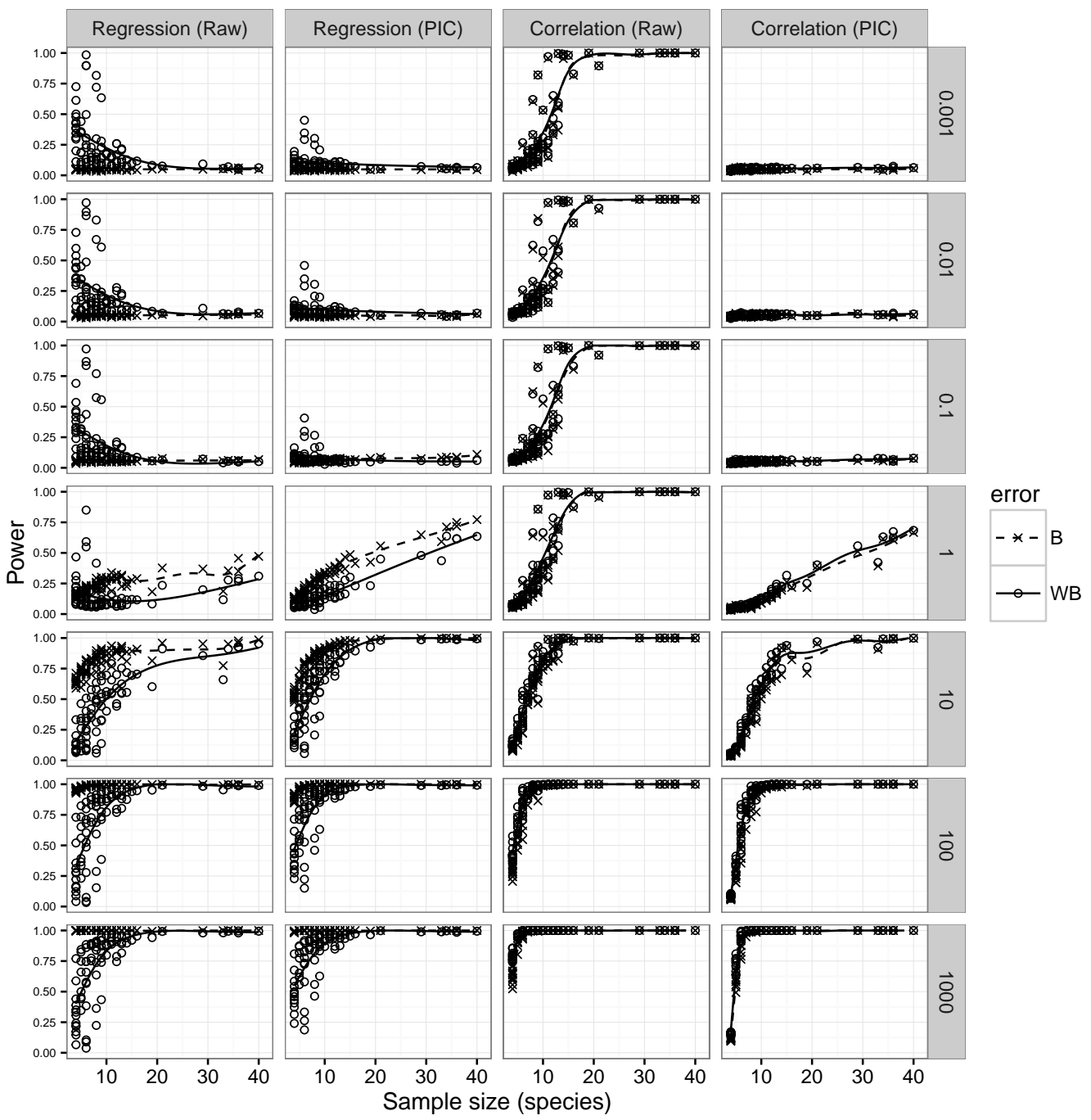

Figure 4.3: Statistical power for regression and correlation tests of drift on raw and PIC data. Rows are different values of effect size $e$. B- Analysis without resampling of $\mathrm{W}$. WB-Analysis with resampling of $\mathrm{W}$. Lines are Lowess fits to the data. 

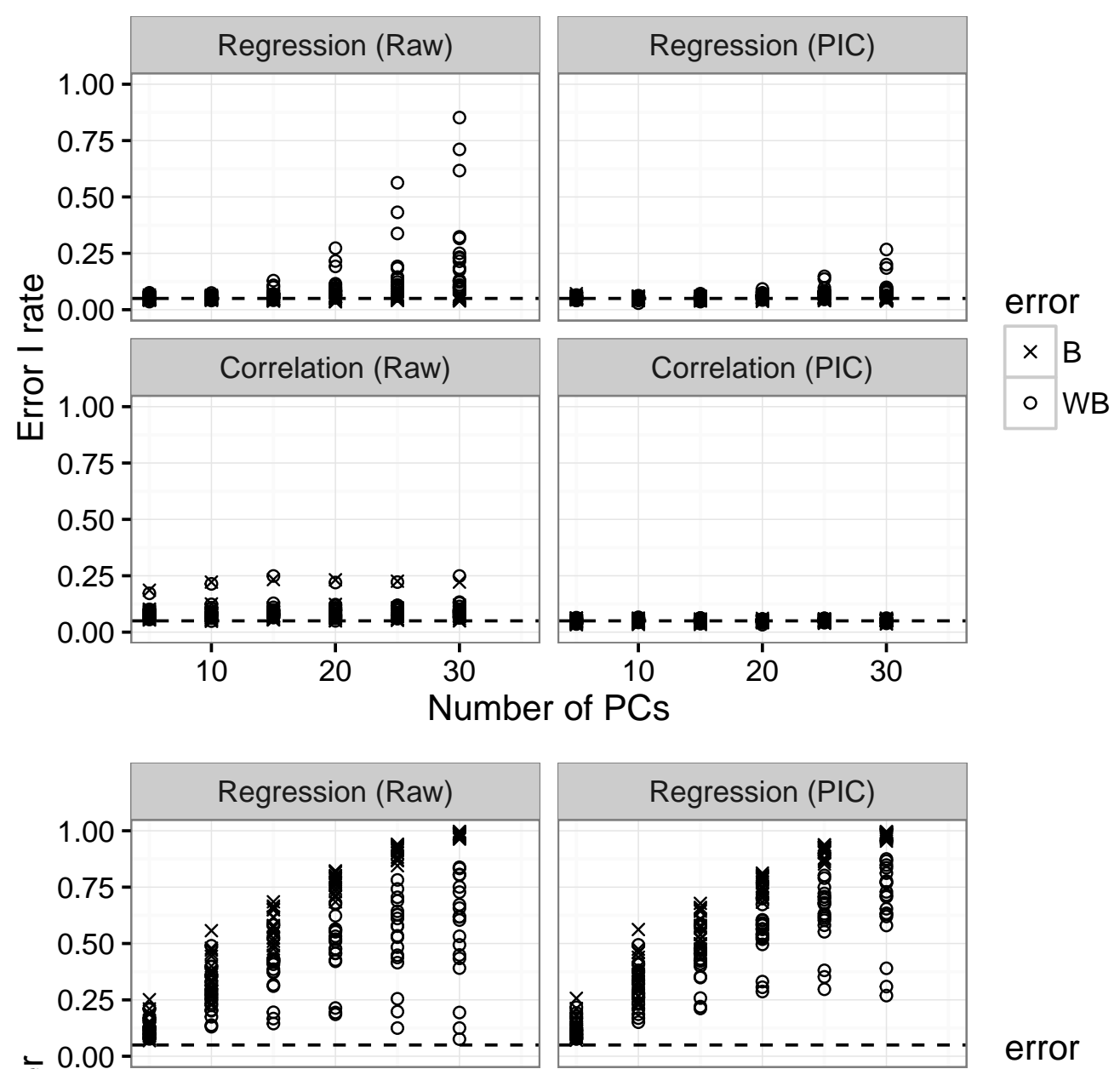

error
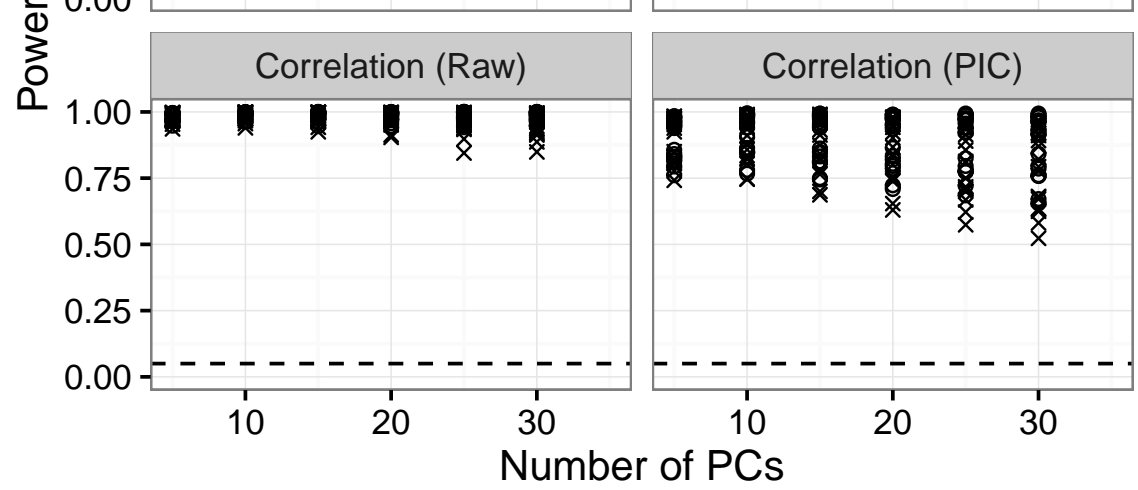

\begin{tabular}{l|l}
$\times$ & $B$ \\
\hline$\circ$ & WB
\end{tabular}

Figure 4.4: Effect of varing varying numbers of principal components (PCs) on Type I error and Power for analysis of clades with sample sizes of 5-6. BAnalysis without resampling of W. WB-Analysis with resampling of W. 
results in an increase of type I error rates for both PIC and raw data. Even though correlation analysis of PIC and raw data have different error rates when $\sigma$ is low, both show a similar error rate when values of $\sigma$ were greater, with a type I error rate equal to 1 for values larger than 10 for raw data and 20 for PIC.

\section{Caniformes}

For the regression test, the parametric approach on Raw data rejected the null hypothesis for Canidae, Ursidae, Procyonidae and Mustelidae (Table 4.2 and fig. 4.6). The non-parametric simulations-based tests rejected drift for those families plus Otariidae and Phocidae, failing to reject the null hypothesis only for Mephitidae (Figure 4.6. The analysis on PIC data rejected drift for Canidae, Procyonidae and Mustelidae, while the simulation approach rejected drift for Canidae, Otariidae, Phocidae, Procyonidae and Mustelidae (Table 4.2 and fig. 4.7). Overall, the non-parametric test on PIC data rejected on more occasions (4 tests), while the parametric regression on PIC rejected the least times (3 tests).

For correlation tests on raw data, all tests, both parametric and nonparametric, managed to reject the null hypothesis of drift, with the exception of the parametric test for Ursidae (Table 4.2). For the analysis of PIC data, both parametric and non-parametric tests agreed in which cases drift was rejected and also in the approximate number of significant correlations (either if they were corrected or not for multiple tests, Table 4.2). Which PCs were correlated varied among different methods (Table 4.3). Almost all correlations found on the non-parametric PIC tests were also found on the parametric PIC tests. Parametric tests on raw data found the most correlations, while non-parametric tests found significant correlation in just a few cases. 


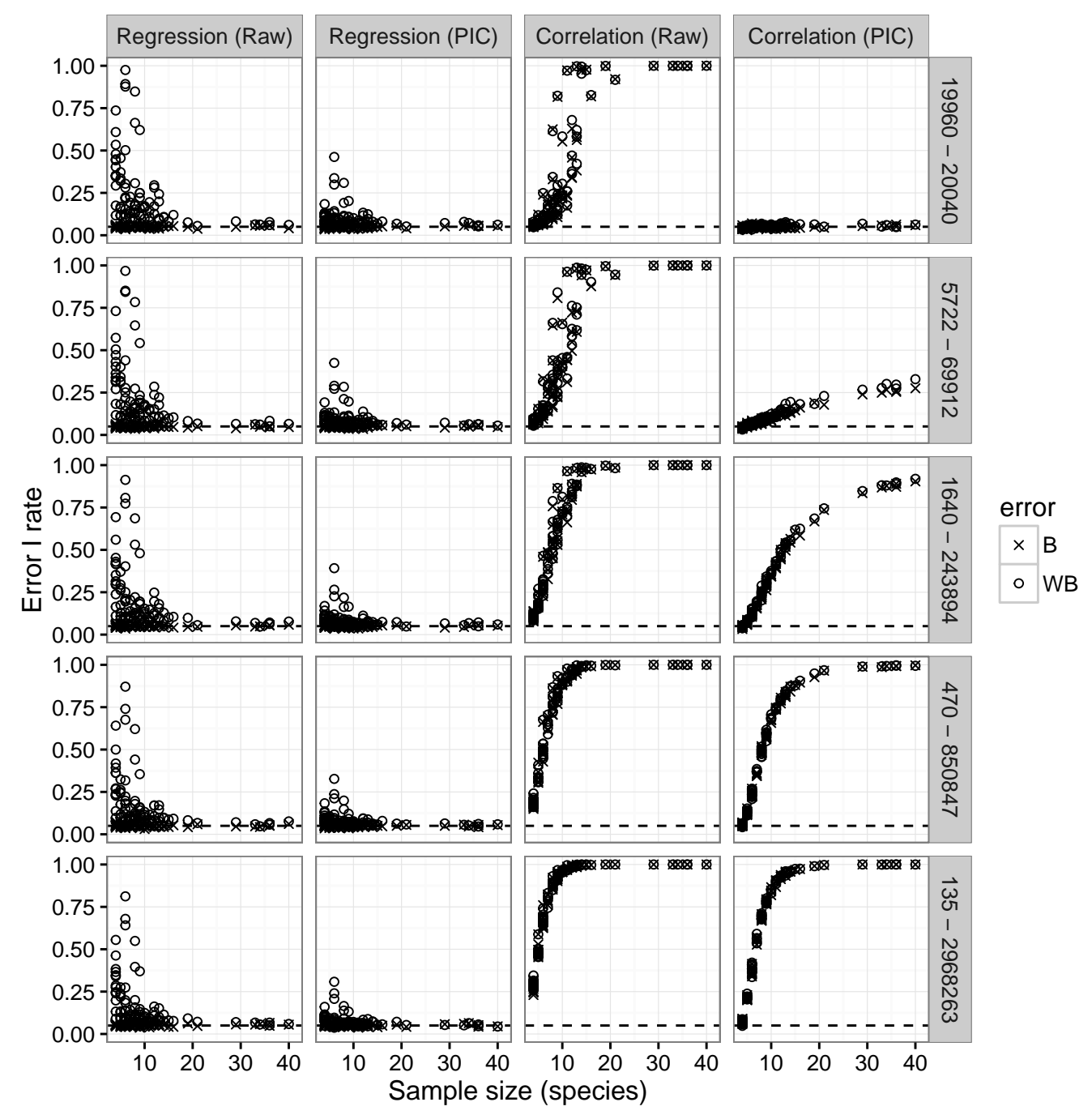

Figure 4.5: Type I error rates for different simulations varying the $N_{e}$ along the phylogeny. Different values on the right of each row represents $95 \%$ of the simulated $N_{e}$ assuming a baseline of $N_{e}=20000$. Lines, from top to bottom, represent $\sigma=[0.1,0.7,1.3,1.9,2.5]$, respectively. See text for further description. B- Analysis without resampling of W. WB-Analysis with resampling of $W$. 

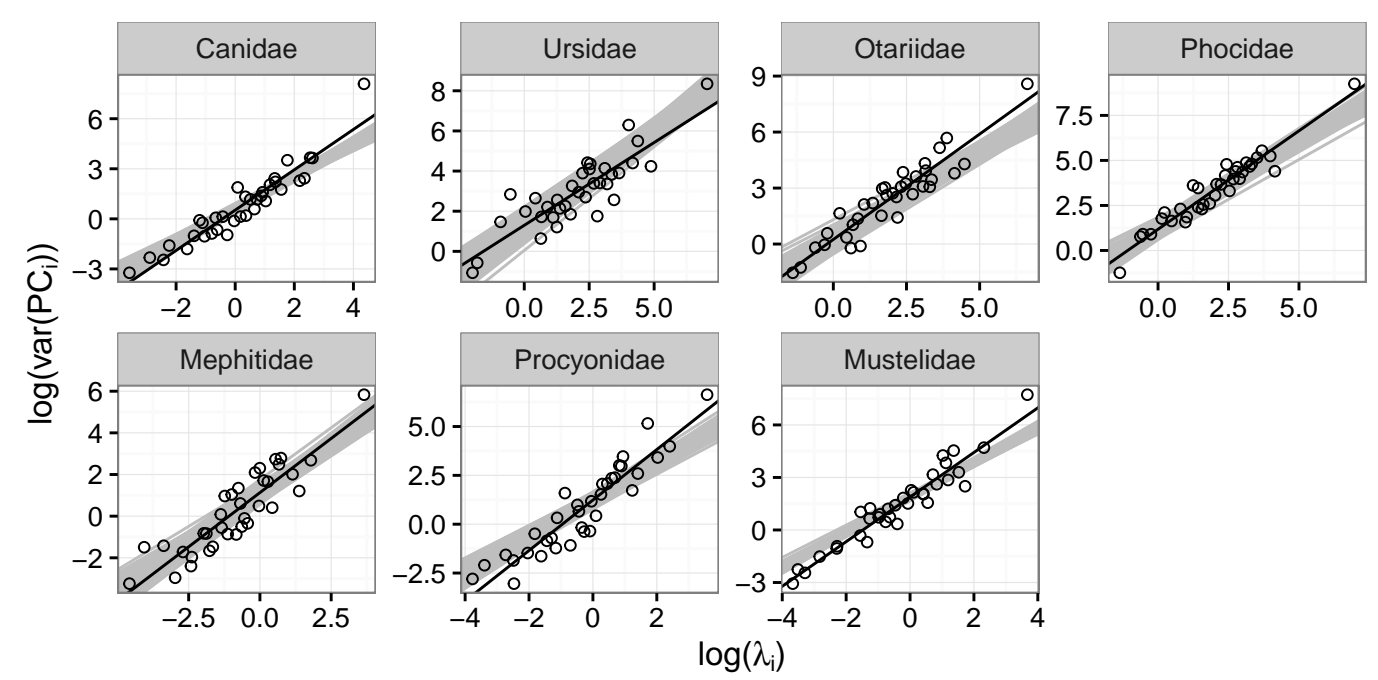

Figure 4.6: Regression analysis of drift on raw data. $\log \left(\lambda_{i}\right)$ - Logeigenvalues of the $\mathbf{W}$ matrix. $\log \left(\operatorname{var}\left(P C_{i}\right)\right)$ - Log-variances of the species means or PICs projected onto W. Gray lines- Regression lines obtained from 100 simulations of drift. Black lines- Ordinary Least Squares regression estimate.
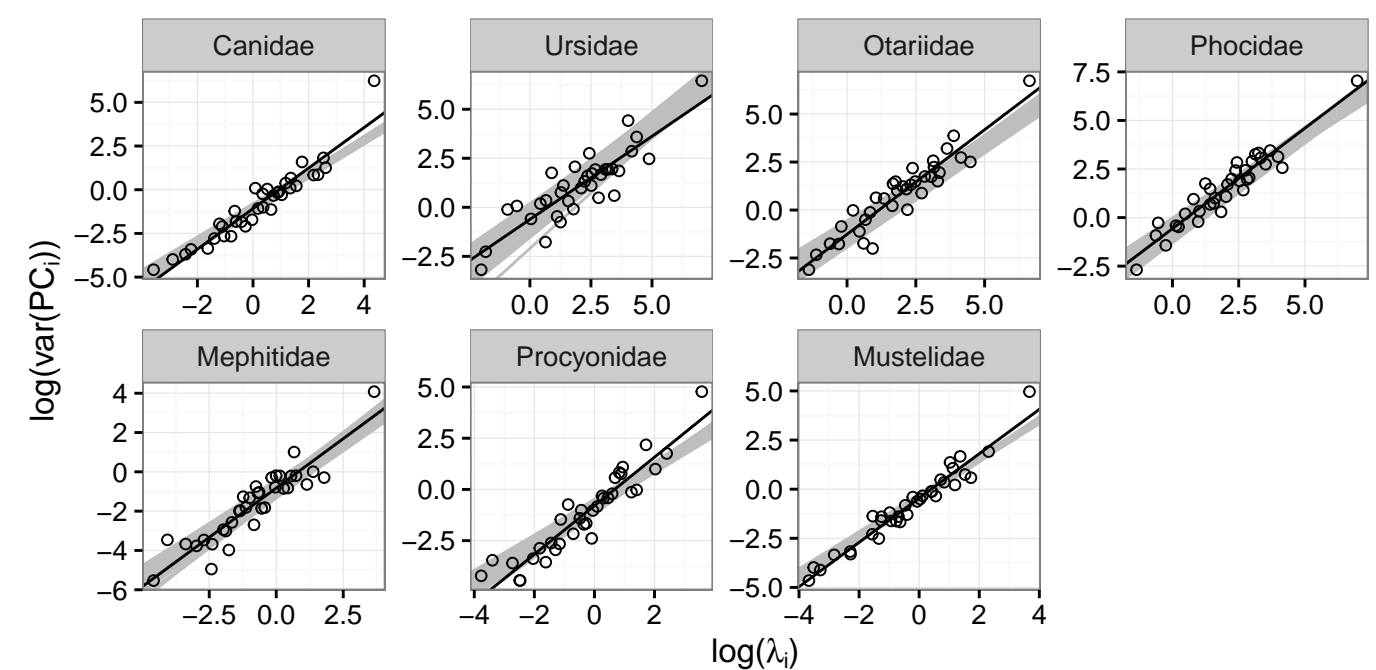

Figure 4.7: Regression analysis of drift on PIC data. $\log \left(\lambda_{i}\right)$ - Logeigenvalues of the $\mathbf{W}$ matrix. $\log \left(\operatorname{var}\left(P C_{i}\right)\right)$ - Log-variances of the species means or PICs projected onto W. Gray lines- Regression lines obtained from 100 simulations of drift. Black lines- Ordinary Least Squares regression estimate. 


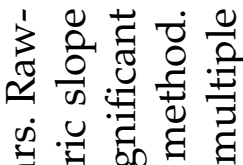

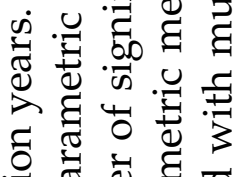

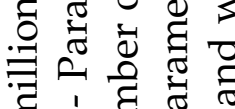

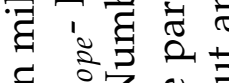

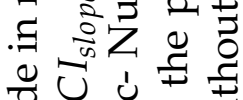

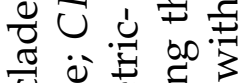

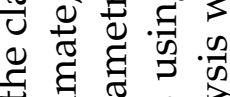

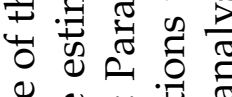

๑)

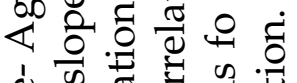
d ज ثี

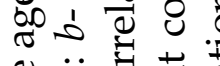

苛.

U.

ఖ

के थै के चै चै

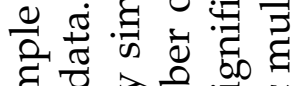

छٓ

的声节范

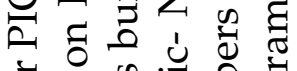
ธี

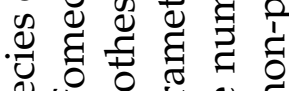

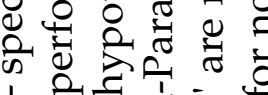

‘ 0 占三車

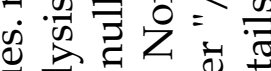

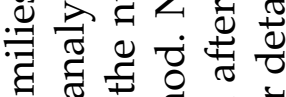

ฮี

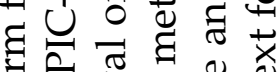

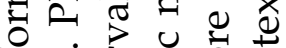

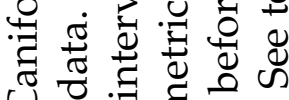

उ 3 ष

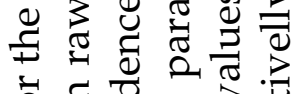

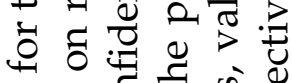

范

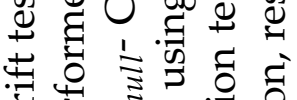

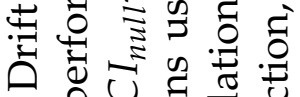

i 0 웡

ㄱ.

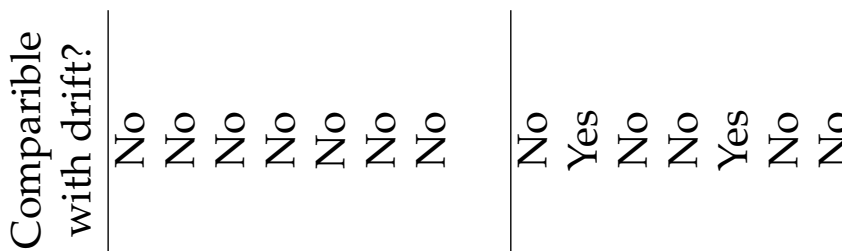

:

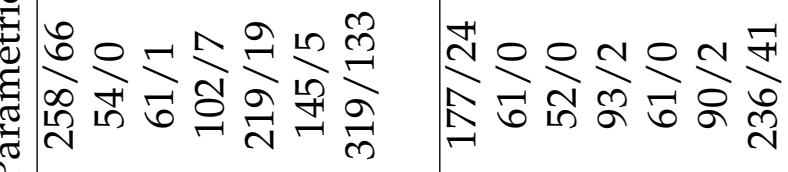

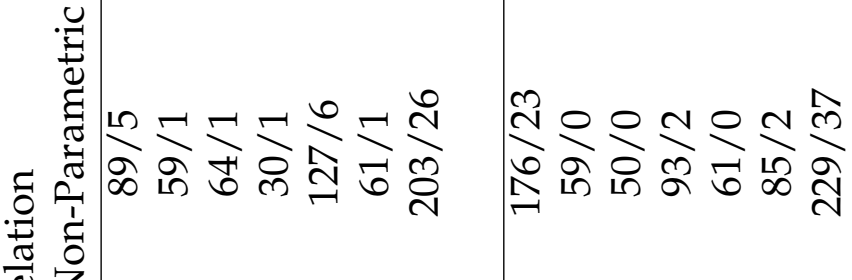

ن

A.

ॠ

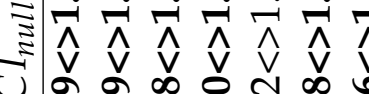

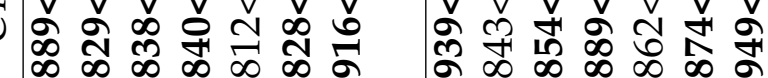

乌ે

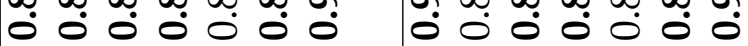

サี่

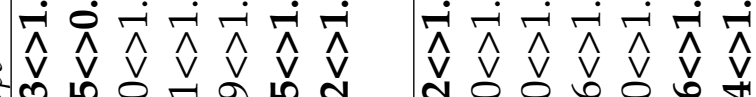

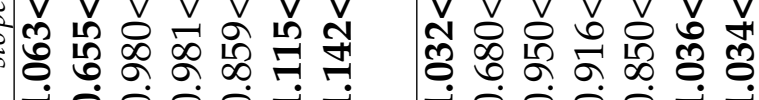

-i் $\dot{0} \dot{0} \dot{0} \boldsymbol{i}$ -

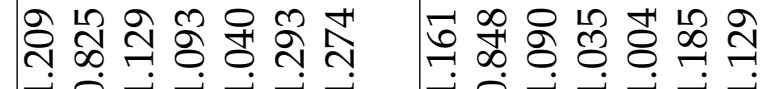

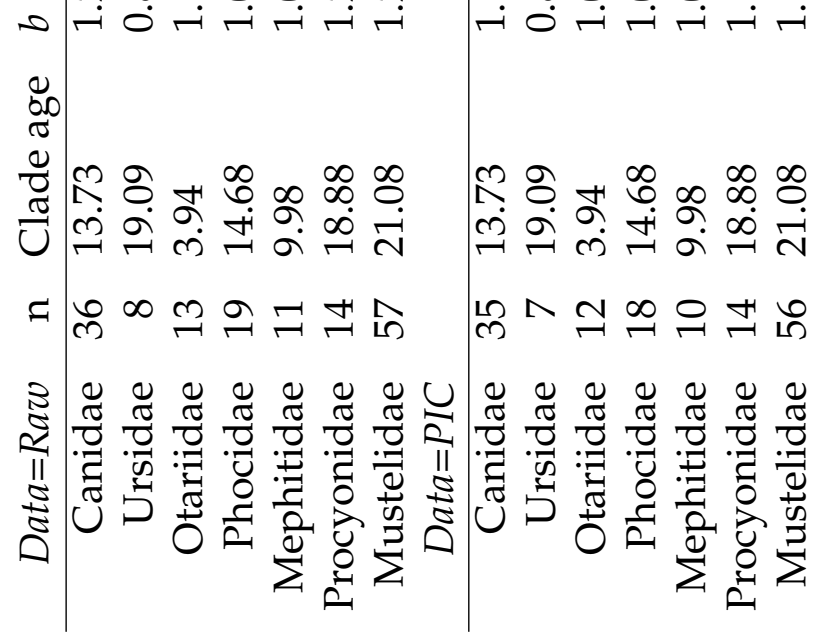

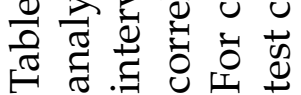


Table 4.3: Significant correlation between the scores of species (raw) or independent contrasts (PIC) on the Principal Components of W

\begin{tabular}{|c|c|c|c|c|}
\hline & \multicolumn{2}{|c|}{ raw } & \multicolumn{2}{|c|}{ PIC } \\
\hline & Parametric & Non-Parametric & Parametric & Non-Parametric \\
\hline Canidae & $\begin{array}{l}1-2,6,9,18,20,23, \\
26,29,34,35 ; 2-3,6, \\
9,18,23,25,26,28, \\
34 ; 3-6,8,23,28 ; \\
4-17,20 ; 6-8,9,16, \\
18,23,25,28,29,30, \\
34 ; 7-10 ; 8-16,23, \\
25,28 ; 9-10,18,20, \\
23,26,28,29,34,35 ; \\
12-20 ; 16-23,25 ; \\
18-28 ; 20-29,34,35 ; \\
23-25,28,29 ; 25-28, \\
29,34 ; 26-35 ; 28-29, \\
34 ; 29-34\end{array}$ & - & $\begin{array}{l}1-18,20,35 ; 2-3,6 \\
8,16,23 ; 3-4,8 ; 6-8 \\
23,28 ; 7-10 ; 8-16 \\
25 ; 9-10 ; 16-25 ; \\
20-35 ; 23-28 ; 25-29 \\
34 ; 29-34 ; 32-33\end{array}$ & $\begin{array}{l}1-9,20,35 ; 2-3,6,8 \\
16,23 ; 3-8,16 ; 6-8 \\
23 ; 8-16,25 ; 9-10 ; \\
16-25 ; 20-35 ; 23-28 ; \\
25-29,34 ; 29-34 ; \\
32-33\end{array}$ \\
\hline Ursidae & - & - & - & - \\
\hline Otariidae & $12-35$ & - & - & - \\
\hline Phocidae & $\begin{array}{l}4-25,30 ; 5-30 ; 12-15 \\
13-30 ; 24-31 ; 28-29\end{array}$ & - & $4-25 ; 28-29$ & $4-25 ; 28-29$ \\
\hline Mephitidae & $\begin{array}{l}5-7,11,13,33 ; 7-11 \\
13,17,30 ; 11-13,22, \\
33 ; 13-15,17,28,33 ; \\
15-33 ; 18-24 ; 24-34 ; \\
28-33\end{array}$ & - & - & - \\
\hline Procyonidae & $\begin{array}{l}1-2,3 ; 2-21 ; 3-13 \\
9-29\end{array}$ & - & $1-2 ; 3-23$ & $1-2 ; 3-23$ \\
\hline Mustelidae & $\begin{array}{l}1-2,4,5,6,7,15,16, \\
19,20,27,29,32,33 ; \\
2-4,5,6,9,13,16, \\
19,20,22,23,25,26, \\
27,29,32,33 ; 3-7,8, \\
10,12,17,21,28,31 ; \\
4-6,7,8,15,16 ; 5-6, \\
12,13,20,21,23,25, \\
26,29,32 ; 6-9,16, \\
19,20,22 ; 7-8,10, \\
15,21,28 ; 8-10,12, \\
13,15,17,21,23,25, \\
26,28,31 ; 9-13,14 \\
19,20,22,33 ; 10-12, \\
17,19,28,30 ; 12-13, \\
21,23,25,26,31 ; \\
13-14,20,21,25,29, \\
32 ; 14-21 ; 15-21,28 ; \\
16-19,22,27,30 ; \\
17-21,22,23,25,26, \\
28,30 ; 19-20,22,30 ; \\
20-22,25,29,32 ; \\
21-23,25,26,28,31 ; \\
22-24,30 ; 23-25,26 ; \\
25-26,28 ; 26-31 ; \\
27-32 ; 28-30 ; 29-32, \\
33\end{array}$ & $\begin{array}{l}1-2,4,6 ; 2-5,6 ; 5-26 \\
7-15 ; 8-21 ; 25-26\end{array}$ & $\begin{array}{l}1-2,4,5,6,15 ; 2-5, \\
6,16,22,29,33 ; 4-6, \\
8 ; 5-19 ; 7-8,31 ; 8-21, \\
31 ; 9-33 ; 10-17 ; \\
11-31 ; 12-13,31 ; \\
13-20 ; 14-21,33 ; \\
16-19,22,30 ; 17-24, \\
26,28,35 ; 21-31 ; \\
22-24,30 ; 25-26 ; \\
26-28,35 ; 28-30 ; \\
29-33\end{array}$ & $\begin{array}{l}1-2,4,5,6,15 ; 2-5, \\
16,29,33 ; 3-7 ; 4-8 ; \\
5-19 ; 7-8 ; 8-21,31 ; \\
9-33 ; 11-31 ; 12-13, \\
31 ; 13-20 ; 14-21,33 ; \\
16-19,22,30 ; 17-24 \\
26,28 ; 22-30 ; 25-26 ; \\
26-28,35 ; 27-32 ; \\
28-30 ; 29-33\end{array}$ \\
\hline
\end{tabular}




\section{4 Discussion}

Here we investigated the statistical properties of two quantitative genetics tests of neutral evolution on a macroevolutionary framework. Both methods rely on the theoretical prediction that interspecific and intraspecific patterns of covariation will match under drift (Lande, 1979). The rejection of this expectation can be seen as evidence that the observed pattern does not match the expectation under drift, opening the door for natural selection as an explanatory hypothesis (Ackermann and Cheverud, 2002, 2004; Marroig and Cheverud, 2004). However, when comparing species in a comparative context, phylogenetic dependency might influence the results, mainly when we are exploring correlations among characters (Díaz-Uriarte and Garland Jr, 1996). Because phylogenetic relationships affects correlations and covariances among traits, we expected that correlation tests would be more sensitive to phylogenetic dependence than regression tests.

The use of a Monte-Carlo resampling procedure to simulate within-species sampling error influenced greatly the results for the regression analysis, inflating type I error rates for low sample sizes and generally reducing power, except when strength of selection was high (large effect sizes $e$ ) and samples were large (Figures 4.2 and 4.3). This is in clear contrast to what was reported by Ackermann and Cheverud (2002), in which type I error rates were deemed adequate even for low samples. Our simulations shows that when we do not resample the $\mathbf{W}$ matrix we obtain adequate type I error rates. So, if Ackermann and Cheverud (2002) performed simulations without accounting for sampling error on $\mathbf{W}$, than that would explain the results reported by them.

The fact that sampling error effect type I error rates and power might be related to the estimation of the eigenvalues of $\mathbf{W}$. Because Ordinary LeastSquare regressions only models error on the dependent variable (the vari- 
ances $\operatorname{var}\left(P C_{i}\right)$ of $\mathbf{B}$ in this case, Equation (4.4)), the introduction of error on the independent variable (eigenvalues $\lambda_{i}$ of $\mathbf{W}$, Equation (4.4)) can be seen as violating OLS model assumptions, making estimates of confidence interval and significance inaccurate (Sokal and Rohlf, 1995).

Analysis performed on PIC data outperforms non-PIC analysis by having adequate type I error rates and by having higher power, a fact more evident for regression analysis (Figures 4.2 and 4.3). Even thought Revell (2007) reached a similar result, in that case the author was testing the matrix correlation between the full $\mathbf{G}$ and $\mathbf{B}$, which includes both variances and covariances among traits. For the regression test as present here, however, covariances between PCs (traits) are not included in the analysis, and the use of PIC should not influence the result of the test. This is because phylogenetic relationships are thought to introduce covariance among traits, but should not influence the trait variances under drift (Hansen and Martins, 1996). However, Rohlf (2006) have shown that the task of comparative methods, specifically of General Least Squares and PIC, is to improve estimates of statistical parameters on phylogenetically structure data. In other words, statistical dependency imposed by the phylogenetic structure increases the standard error of the estimated variances of $\mathbf{B}$, a fact that, when combined with sampling error on $\mathbf{W}$, helps to disrupt the expected proportionality between $\lambda_{i}$ and $\operatorname{var}\left(P C_{i}\right)$. Using comparative methods might help quantitative genetic analysis by providing a better estimate of not only covariances, but also of variances of B (Revell, 2007).

Correlation analysis showed the most drastic difference between analysis of raw and PIC data. While analysis of raw data showed inadequate type I error rates for almost all sample sizes, PIC analysis showed nominal 5\% levels for all samples (Figure 4.2), a well known result for the analysis of correlation on phylogenetically structured data (Díaz-Uriarte and Garland Jr, 
1996). This is further corroborated by the fact that if we apply transformations on the tree in order to make it more "star-like" (i.e. make tips more independent of each other), type I error rates for raw data analysis falls as a function of the transformation parameter (Figure E.1). This is consistent for what was found by Revell (2007), were linearly decreasing speciation rates (a "star-like" tree) resulted in similar values for correlations between $\mathbf{B}$ and G both with PIC or raw data.

For regression analysis the reduction of the number of PCs can help to bring type I errors down to nominal levels for regression analysis (Figure 4.4). Since PCs associated with lower eigenvalues are thought to contain potential source of error and noise (Strauss, 2010; Mitteroecker and Bookstein, 2011; Marroig et al., 2012), particularly for small sample sizes, the reduction of the number of PCs might remove potential sources of noise and within-group error. Additionally this could help in the analysis of groups lacking a phylogeny: by adjusting the number of PCs, one could obtain adequate type I error rates for the analysis even for analysis of raw data. Thus, regression analysis can be a very important tool in the preliminary investigation of natural selection for under-studied groups.

The removal of PCs, however, can lead to lower power for the regression analysis, imposing a trade-off between type I error and power for low sample sizes. In this context, the use of PIC is particularly advantageous because, despite presenting the same trade-off, it allows the retention of more PCs in order to have adequate type I error. For example, to obtain nominal levels of type I error in raw data we would have to retain approximately 10 PCs, what would lead to a maximum power of 0.6 , while with PIC we could retain 20 PCs to have the same type I error, leading to a maximum power of 0.8 . So even though regression analysis can be performed in the absence of phylogenetic information, the use of comparative methods can greatly 
improves the results.

Curiously, the removal of more PCs effects correlation analysis by increasing average power, not lowering it (Figure 4.4). This might be the because, as the number of variables increases in relation to sample size, power goes down. Thus, the reduction of PCs for correlation analysis suggested by Marroig and Cheverud (2004) might not be justified in order to reduced type I errors (which are unchanged for different number of retained axis, Figure 4.4) but to increase power. Also, differently from the regression analysis, correlation analysis should not be performed in the absence of phylogenetic information, independently of how many PCs are retained.

Correlation analysis were particularly sensitive to fluctuations in $N_{e}$ (Figure 4.5). The higher the fluctuation in $N_{e}$, the larger the inflation of type I error rates, specially for PIC data. One premise of the use of PIC is that branch lengths will be proportional to the expected divergence between species (Felsenstein, 1985). Even though it is usually assumed that expected divergence is directly proportional to time under drift, this is evidently not true when $N_{e}$ fluctuates (Equation (4.1)). In those cases, PIC estimates will be imprecise because the standardization by time will not translate into a standardization by expected divergence.

In our simulations, as $N_{e}$ fluctuation increases, the mismatch between branch lengths expressed in years and the expected amount of evolution will go up, reflecting in a inflated type I error for correlation tests on PIC. Correlation analysis on raw data seems to be less affected by fluctuations in $N_{e}$ because of inflated type I errors to begin with. When $N_{e}$ fluctuation is high, error I rates resemble the rate of rejection of the null hypothesis when we introduce selection for both raw and PIC data (Figure 4.3), probably because we are altering rates of evolution, mimicking the effects of selection (Garland, 1992; Martins et al., 2002), rendering correlation tests inadequate 
in this case.

Even though it has been long shown that violation of the underlying model leads to a poor performance of comparative methods (Díaz-Uriarte and Garland Jr, 1996; Garland, 1992; Martins et al., 2002), the use of singlerate models can be justified by assuming a mutation-drift-equilibrium model were the variance added by mutation and the amount of variance lost by drift are equal. In that case we can rewrite Equation (4.1) as

$$
\mathbf{B}=\mathbf{M} 2 t
$$

were $\mathbf{M}$ is a covariance matrix of mutational effects. This has the convenient propriety of making the rate of evolution independent of population size (Lande, 1979, 1980; Felsenstein, 1988; Lynch, 1989; Hansen and Martins, 1996), thus making the use of quantitative genetics tests of proportionality adequate even in the presence of demographic variation.

In the absence of selection, equilibrium can be reached after $4 N_{e}$ generations irrespective of initial conditions (Turelli et al., 1988). For Caniformes, if we take female sexual maturity as a minimum benchmark for generation time, we would have a maximum (conservative) values of 6.6 years (obtained from the AnAge database; Tacutu et al., 2012). Furthermore, if we assume an average $N_{e}$ of 200000, than Caniformes clades would have reached equilibrium at a maximum age of 1.3 million years. Even though this is not a problem for the analysis of the Caniform families evaluated here (Table 4.2), it can pose an issue for less inclusive and younger taxa, such as tribes and genus, or even larger clades if $N_{e}$ or generation time are high. In cases were the populations have not reached equilibrium, the regression test might be an alternative because, differently from the correlation test, regression tests were surprisingly robust even for large fluctuations of $N_{e}$, showing similar type I error rates for all values of $\sigma$ (Figure 4.5). 
The investigation of the Caniform families confirms the expectations from the simulations. For both tests, analyses performed on PIC data reject drift in less cases then analysis on raw data, as would be expected by the lower type I error of the former Table 4.2. For correlation data of PIC, both parametric and non-parametric methods produced very similar results Table 4.3, probably because the non-parametric procedure for correcting for multiple tests was adequate for PIC data. Parametric and non-parametric correlation tests of raw data, on the other hand, differed greatly, both in number and in what correlations were found Table 4.3. This suggests that the use of simulations produce confidence intervals of the null hypothesis that are too wide to be reliable for raw data. For regression analysis, on the other hand, simulations presented narrower confidence intervals, rejecting drift in more cases then the parametric tests Table 4.2. This further reinforces the idea that OLS regressions might not be adequate to test proportionality between $\mathbf{B}$ and $\mathbf{W}$ because it fails to construct adequate confidence intervals for the null hypothesis. Since models for phenotypic evolution required for the test of quantitative genetics are simple and readily implementable (i.e. brownian motion Lande, 1976), simulations for regression analysis should always be preferred when a phylogeny is available.

Carnivora in general is considered a test case for adaptive evolution due to its diversity of ecology and associated morphology (Goswami, 2010). Thus, the fact that we failed to identify deviation of drift for two families, Mephitidae (skunks) and Ursidae (bears), is worth further attention.

Mephitidae skull adaptations has received little attention. Despite the fact that the family has been included in ecomorphological analysis of more inclusive taxa (Friscia et al., 2007; Van Valkenburgh, 2009; Figueirido et al., 2010; Schiaffini and Prevosti, 2013; Tseng and Flynn, 2015; Dumont et al., 2016), skunks are usually described as having a similar omnivore feeding 
ecology. Furthermore, no previous work on the group have included the most morphologically divergent genus, the Mydaus, probably because its placement within Mephitidae was controversial till recently (Sato, 2016). For these reasons it is unclear how we can interpret the results presented here for this family. It could be the case that, because skunks are ecologically and morphologically conserved, the signal of selection might be difficult to detect. Further studies of the ecomorphology of this family will surely help to elucidate these issues.

Ursidae is a species poor family that has a considerable diversity in feeding ecology, from omnivorous diet (U. arctos, U. thibetanus, $U$. americanus, H. malayanus), insectivores (M. ursinus), hypercarnivores (U. maritimus) and herbivores (A. melanoleuca, T. ornatus). The fact that our PIC analysis suggests that the evolution of the skull in bears is consistent with drift is at odds with other interpretations of the association between morphology of the skull and feeding ecology (e.g. Figueirido and Soibelzon, 2009; Figueirido et al., 2009, 2010, 2011b, 2013). However, it has been shown that mandibular and dental morphology have stronger ecomorphological signal than cranial traits specifically for bears (Sacco and Van Valkenburgh, 2004; Christiansen, 2008; van Heteren et al., 2015) and for Carnivores in general (Figueirido et al., 2011a). Additionally, some aspects of bear skull morphology can be present in species that uses very different food sources (e.g. large diastema in the carnivorous $U$. maritimus, a trait associated with increased selection and manipulation of vegetal matter, Mattson, 1998), indicating a generally well adapted skull shape for a variety of habits. Alternatively, adaptations to specific food sources can be rare and restricted to a few cases (e.g. hypercarnivores and herbivores, Figueirido et al., 2009; Slater et al., 2010; Figueirido et al., 2010, 2011a), thus making selection difficult to detect.

Both Mephitidae and Ursidae are the least diverse families analyzed 
618 here. Our simulations shows that, for small sample sizes, the regression 619 analysis have an inflated type I error (Figure 4.2), making the lack of rejection of the null hypothesis for both families even more surprising. However, ${ }_{621}$ small samples are associated with low power, something that is particularly ${ }_{622}$ problematic when strength of selection is small (Figure 4.3). Therefore, the 623 combination of low samples and weak (or at least rare) selection could make ${ }_{624}$ the detection of natural selection through these methods difficult. The ad${ }_{625}$ dition of fossil species and the analysis of other traits (e.g. mandibular and 626 dental morphology) might help to clarify this issue. 


\section{References}

Ackermann, R. R. and Cheverud, J. M. (2000). Phenotypic covariance structure in tamarins(genus Saguinus): a comparison of variation patterns using matrix correlation and common principal component analysis. American Journal of Physical Anthropology, 111(4):489-501.

Ackermann, R. R. and Cheverud, J. M. (2002). Discerning evolutionary processes in patterns of tamarin (genus Saguinus) craniofacial variation. American Journal of Physical Anthropology, 117(3):260-271.

Ackermann, R. R. and Cheverud, J. M. (2004). Detecting genetic drift versus selection in human evolution. Proceedings of the National Academy of Sciences of the United States of America, 101(52):17946-17951.

Agnarsson, I., Kuntner, M., and May-Collado, L. J. (2010). Dogs, cats, and kin: A molecular species-level phylogeny of Carnivora. Molecular Phylogenetics and Evolution, 54(3):726-745.

Arnold, C., Matthews, L. J., and Nunn, C. L. (2010). The 10kTrees website: A new online resource for primate phylogeny. Evolutionary Anthropology, 19(3):114-118.

Arnold, S. J., Pfrender, M., and Jones, A. G. (2001). The adaptive landscape as a conceptual bridge between micro-and macroevolution. Genetica, 112(1):9-32.

Baker, J., Meade, A., Pagel, M., and Venditti, C. (2016). Positive phenotypic selection inferred from phylogenies. Biological Journal of the Linnean Society, 118(1):95-115.

Bartoszek, K., Pienaar, J., Mostad, P., Andersson, S., and Hansen, T. F. (2012). A phylogenetic comparative method for studying multivariate adaptation. Journal of Theoretical Biology, 314:204-215.

Cheverud, J. M. (1982). Phenotypic, genetic, and environmental morphological integration in the cranium. Evolution, 36(3):499-516.

Cheverud, J. M. (1984). Quantitative genetics and developmental constraints on evolution by selection. Journal of Theoretical Biology, 110(2):155171.

Cheverud, J. M. (1996). Quantitative genetic analysis of cranial morphology in the cotton-top (Saguinus oedipus) and saddle-back (S. fuscicollis) tamarins. Journal of Evolutionary Biology, 9(1):5-42.

Cheverud, J. M., Rutledge, J., and Atchley, W. (1983). Quantitative genetics of development: genetic correlations among age-specific trait values and the evolution of ontogeny. Evolution, 37(5):895-905. 
Christiansen, P. (2008). Feeding ecology and morphology of the upper canines in bears (carnivora: Ursidae). Journal of Morphology, 269(7):896-908.

Cressler, C. E., Butler, M. A., and King, A. A. (2015). Detecting Adaptive Evolution in Phylogenetic Comparative Analysis Using the Ornstein-Uhlenbeck Model. Systematic Biology, 64(6):953-968.

Darwin, C. (1859). On the Origin of Species by Means of Natural Selection. John Murray, London.

Díaz-Uriarte, R. and Garland Jr, T. (1996). Testing Hypotheses of Correlated Evolution Using Phylogenetically Independent Contrasts. 45(1):27-47.

Dumont, M., Wall, C. E., Botton Divet, L., Goswami, A., Peigné, S., and Fabre, A.-C. (2016). Do functional demands associated with locomotor habitat, diet, and activity pattern drive skull shape evolution in musteloid carnivorans? Biological Journal of the Linnean Society, 117(4):858-878.

Felsenstein, J. (1985). Phylogenies and the comparative method. The American Naturalist, 125(1):1-15.

Felsenstein, J. (1988). Phylogenies and quantitative characters. Annual Review of Ecology and Systematics, 19:445-471.

Felsenstein, J. (2008). Comparative Methods with Sampling Error and Within-Species Variation: Contrasts Revisited and Revised. The American Naturalist, 171(6):713-725.

Figueirido, B., MacLeod, N., Krieger, J., Renzi, M. D., Perez-Claros, J., and PALMQVIST, P. (2011a). Constraint and adaptation in the evolution of carnivoran skull shape. Paleobiology, 37(3):490-518.

Figueirido, B., Palmqvist, P., and Pérez-Claros, J. A. (2009). Ecomorphological correlates of craniodental variation in bears and paleobiological implications for extinct taxa: an approach based on geometric morphometrics. Journal of Zoology, 277(1):70-80.

Figueirido, B., Serrano-Alarcón, F. J., and Palmqvist, P. (2011b). Geometric morphometrics shows differences and similarities in skull shape between the red and giant pandas. Journal of Zoology, 286(4):293-302.

Figueirido, B., Serrano-Alarcón, F. J., Slater, G. J., and Palmqvist, P. (2010). Shape at the cross-roads: homoplasy and history in the evolution of the carnivoran skull towards herbivory. Journal of Evolutionary Biology, 23(12):2579-2594.

Figueirido, B. and Soibelzon, L. H. (2009). Inferring palaeoecology in extinct tremarctine bears (Carnivora, Ursidae) using geometric morphometrics. Lethaia, 43(2):209-222. 
Figueirido, B., Tseng, Z. J., and Martín-Serra, A. (2013). Skull shape evolution in durophagous carnivorans. Evolution, 67(7):1975-1993.

Fisher, R. A. (1930). The genetical theory of natural selection: a complete variorum edition. Oxford University Press.

Friedman, J. H. (1989). Regularized discriminant analysis. Journal of the American Statistical Association, 84(405):165-175.

Friscia, A. R., Van Valkenburgh, B., and Biknevicius, A. R. (2007). An ecomorphological analysis of extant small carnivorans. Journal of Zoology, 272(1):82-100.

Fulton, T. L. and Strobeck, C. (2010). Multiple fossil calibrations, nuclear loci and mitochondrial genomes provide new insight into biogeography and divergence timing for true seals (Phocidae, Pinnipedia). Journal of Biogeography, 37:814-829.

Garland, T. (1992). Rate tests for phenotypic evolution using phylogenetically independent contrasts. The American Naturalist, 140(3):509-519.

Garland Jr, T., Harvey, P., and Ives, A. R. (1992). Procedures for the Analysis of Comparative Data Using Phylogenetically Independent Contrasts. Systematic Biology, 41(1):18-32.

Giannini, N. P. and Goloboff, P. (2010). Delayed-response phylogenetic correlation: an optimization-based method to test covariation of continuous characters. Evolution, 67(7):1885-1898.

Goolsby, E. W., Bruggeman, J., and Ane, C. (2016). Rphylopars: Fast Multivariate Phylogenetic Comparative Methods for Missing Data and WithinSpecies Variation. Methods in Ecology and Evolution, pages 1-19.

Goswami, A. (2010). Introduction to carnivora. In Goswami, A. and Friscia, A., editors, Carnivoran Evolution. New views on phylogeny, form and function, pages 1-24. Cambridge University Press.

Gould, S. J. and Lewontin, R. C. (1979). The spandrels of San Marco and the Panglossian paradigm: a critique of the adaptationist programme. Proceedings of the Royal Society of London. Series B, Biological Sciences, 205(1161):581-598.

Hansen, T. F. and Martins, E. (1996). Translating between microevolutionary process and macroevolutionary patterns: the correlation structure of interspecific data. Evolution, 50(4):1404-1417.

Hubbe, A., Melo, D., and Marroig, G. (2016). A case study of extant and extinct Xenarthra cranium covariance structure: implications and applications to paleontology. Paleobiology, 42(3):465-488. 
Jones, K. E. and Goswami, A. (2009). Quantitative analysis of the influences of phylogeny and ecology on phocid and otariid pinniped (Mammalia; Carnivora) cranial morphology. Journal of Zoology, 280(3):297-308.

King, A. A. and Butler, M. A. (2009). ouch: Ornstein-Uhlenbeck models for phylogenetic comparative hypotheses. R package version 0.9-61.

Lande, R. (1976). Natural selection and random genetic drift in phenotypic evolution. Evolution, 30(2):314-334.

Lande, R. (1979). Quantitative genetic analysis of multivariate evolution, applied to brain: body size allometry. Evolution, 33(1):402-416.

Lande, R. (1980). Genetic variation and phenotypic evolution during allopatric speciation. The American Naturalist, 116(4):463-479.

Lofsvold, D. (1988). Quantitative genetics of morphological differentiation in Peromyscus. II. Analysis of selection and drift. Evolution, 42(1):54-67.

Lynch, M. (1989). Phylogenetic hypotheses under the assumption of neutral quantitative-genetic variation. Evolution, 43(1):1-17.

Marroig, G. and Cheverud, J. M. (2001). A comparison of phenotypic variation and covariation patterns and the role of phylogeny, ecology, and ontogeny during cranial evolution of New World monkeys. Evolution, 55(12):2576-2600.

Marroig, G. and Cheverud, J. M. (2004). Did natural selection or genetic drift produce the cranial diversification of neotropical monkeys? The American Naturalist, 163(3):417-428.

Marroig, G., Melo, D. A. R., and Garcia, G. R. G. (2012). Modularity, noise, and natural selection. Evolution, 66(5):1506-1524.

Marroig, G., Vivo, M., and Cheverud, J. M. (2004). Cranial evolution in sakis (Pithecia, Platyrrhini) II: evolutionary processes and morphological integration. Journal of Evolutionary Biology, 17(1):144-155.

Martins, E., Diniz-Filho, J., and Housworth, E. (2002). Adaptive constraints and the phylogenetic comparative method: a computer simulation test. Evolution, 56(1):1-13.

Mattson, D. J. (1998). Diet and morphology of extant and recently extinct northern bears. Ursus, 10:479-496.

Maynard-Smith, J., Burian, R., Kauffman, S., Alberch, P., Campbell, J., Goodwin, B., Lande, R., Raup, D., and Wolpert, L. (1985). Developmental constraints and evolution: a perspective from the Mountain Lake Conference on Development and Evolution. The Quarterly Review Of Biology, 60(3):265-287. 
Mitteroecker, P. and Bookstein, F. (2011). Linear Discrimination, Ordination, and the Visualization of Selection Gradients in Modern Morphometrics. Evolutionary Biology, 38(1):100-114.

Nyakatura, K. and Bininda-Emonds, O. R. P. (2012). Updating the evolutionary history of Carnivora (Mammalia): a new species-level supertree complete with divergence time estimates. BMC Biology, 10(12):1-31.

Oliveira, F. B. d., Porto, A., and Marroig, G. (2009). Covariance structure in the skull of Catarrhini: a case of pattern stasis and magnitude evolution. Journal of Human Evolution, 56(4):417-430.

Prôa, M., O'higgins, P., and Monteiro, L. R. (2013). Type I error rates for testing genetic drift with phenotypic covariance matrices: a simulation study. Evolution, 67(1):185-195.

R Core Team (2016). R: A Language and Environment for Statistical Computing.

Revell, L. J. (2007). Testing the genetic constraint hypothesis in a phylogenetic context: a simulation study. Evolution, 61(11):2720-2727.

Rohlf, F. J. (2006). A comment on phylogenetic correction. Evolution, 60(7):1509-1515.

Sacco, T. and Van Valkenburgh, B. (2004). Ecomorphological indicators of feeding behaviour in the bears (Carnivora: Ursidae). Journal of Zoology, 263(1):41-54.

Sato, J. J. (2016). The Systematics and Taxonomy of the World's Badger Species-A Review. In Proulx, G. and San, E. D. L., editors, Badgers systematics, biology, conservation and research techniques, pages 1-30. researchgate.net.

Schiaffini, M. I. and Prevosti, F. J. (2013). Trophic Segregation of Small Carnivorans (Carnivora: Mustelidae and Mephitidae) from the Southern Cone of South America. Journal of Mammalian Evolution, 21(4):407-416.

Slater, G. J., Dumont, E. R., and Van Valkenburgh, B. (2009). Implications of predatory specialization for cranial form and function in canids. Journal of Zoology, 278(3):181-188.

Slater, G. J., Figueirido, B., Louis, L., Yang, P., and Van Valkenburgh, B. (2010). Biomechanical consequences of rapid evolution in the polar bear lineage. PLOS ONE, 5(11):e13870.

Slater, G. J., Harmon, L. J., and Alfaro, M. E. (2012). Integrating fossils with molecular phylogenies improves inference of trait evolution . Evolution, 66(12):3931-3944. 
Sokal, R. R. and Rohlf, F. J. (1995). Biometry (3rd edn). WH Freman and company: New York.

Strauss, R. (2010). Discriminating Groups of Organisms. In Elewa, A. M. T., editor, Morphometrics for Nonmorphometricians, pages 73-91. Springer Berlin Heidelberg, Berlin, Heidelberg.

Tacutu, R., Craig, T., Budovsky, A., Wuttke, D., Lehmann, G., Taranukha, D., Costa, J., Fraifeld, V. E., and de Magalhaes, J. P. (2012). Human Ageing Genomic Resources: Integrated databases and tools for the biology and genetics of ageing. Nucleic Acids Research, 41:D1027-D1033.

Tseng, Z. J. and Flynn, J. J. (2015). An integrative method for testing formfunction linkages and reconstructed evolutionary pathways of masticatory specialization. Journal of The Royal Society Interface, 12(107):1-10.

Tseng, Z. J. and Wang, X. (2011). Do convergent ecomorphs evolve through convergent morphological pathways? Cranial shape evolution in fossil hyaenids and borophagine canids (Carnivora, Mammalia). Paleobiology, 37(3):470-489.

Turelli, M., Gillespie, J. H., and Lande, R. (1988). Rate tests for selection on quantitative characters during macroevolution and microevolution. Evolution, 42(5):1085-1089.

van Heteren, A. H., MacLarnon, A., Soligo, C., and Rae, T. C. (2015). Functional morphology of the cave bear (Ursus spelaeus) mandible: a 3D geometric morphometric analysis. Organisms Diversity E Evolution, 16(1):299314.

Van Valkenburgh, B. (2009). Costs of carnivory: tooth fracture in Pleistocene and Recent carnivorans. Biological Journal of the Linnean Society, 96:68-81.

Venditti, C., Meade, A., and Pagel, M. (2011). Multiple routes to mammalian diversity. Nature, 479(7373):393-396.

Wroe, S. and Milne, N. (2007). Convergence and Remarkably Consistent Constraint in the Evolution of Carnivore Skull Shape. Evolution, 61(5):1251-1260.

Zeng, Z. B. (1988). Long-term correlated response, interpopulation covariation, and interspecific allometry. Evolution, 42(2):363-374. 
Capítulo 5

Conclusões 
PADRÃO DE INTEGRAÇÃO EM CANIDAE E RELAÇÕES COM

DOMESTICAÇÃO DE C. FAMILIARIS 5. CONCLUSÕES

Padrão de integração em Canidae e relações com domesticação de C. familiaris

$\mathrm{Na}$ presente tese eu demonstrei que Carnivora como um todo apresenta um padrão conservado de integração morfológica (Capítulo 3). Visto que o grupo apresentam uma enorme diversidade de hábitos e estratégias alimentares, tal fenômeno provavelmente se deve à ação de seleção estabilizadora interna, resultando na manutenção das vias ontogenéticas que atuam na formação do crânio (Cheverud, 1996). Apesar desta estabilidade, foi diagnosticada uma distinção da família Canidae das demais, que são mais similares entre si e mais dissimilares em relação a espécies de outras famílias. Essa mudança está associada ao aumento da flexibilidade, integração e variância relativa na região da face das espécies de canídeos.

Tendo este tipo de resultado em mente, é difícil não pensar nas possíveis conexões do fenômeno aqui detectado e a diversidade morfológica no cachorro doméstico Canis familiaris. Excetuando-se a variação extrema de tamanho e aspectos da morfologia "mole", como pelagem, forma de orelhas e cauda, a variação do tamanho relativo do rostro de cachorros é extrema, rivalizando a variação vista não apenas em Canidae selvagem (Wayne, 1986), mas em Carnivora como um todo (Drake e Klingenberg, 2008). O fato das espécies de Canidae apresentarem uma face mais modular, podendo responder mais diretamente à seleção natural, sugere uma possível explicação para a grande diversidade de forma craniana observada nos cachorros.

A proposta de que Canidae como um todo é estruturalmente distinto dos demais Carnivora em sua capacidade de resposta à seleção não é nova. Laidlaw et al. (2007) demostraram que, assim como cachorros domésticos, Canidae apresentava uma taxa elevada de sequências repetitivas puras (não interrompidas por mutações pontuais) no genoma. A presença de sequên- 
PADRÃO DE INTEGRAÇÃO EM CANIDAE E RELAÇÕES COM 5. CONCLUSÕES DOMESTICAÇÃO DE C. FAMILIARIS

cias mais puras, quando encontradas em genes regulatórios, potencializa a capacidade da espécie de criar nova variação por duplicação de material genômico, variação esta que pode subsequentemente ser selecionada (Fondon e Garner, 2004; Laidlaw et al., 2007). Assim, diferenças na arquitetura genética de Canidae podem ter sido essenciais para o sucesso da domesticação de cachorros.

Evidências adicionais para a "domesticabilidade"de Canidae vem do famoso experimento com raposas de Belyaev, na antiga União Soviética e atual Rússia (Belyaev et al., 1985; Trut, 1999; Trut et al., 2009; Kukekova et al., 2008; Trut et al., 2004). Nesse experimento de 40 anos, indivíduos de Vulpes vulpes selvagens foram selecionados para menor agressividade, o que resultou em uma miríade de modificações fenotípicas em poucas gerações, inclusive em caracteres cranianos ligados à face (Figura 5.1). A diminuição de agressividade, medo e estresse em animais domesticados parecem estar associados à redução do tamanho e da função da glândula adrenal (Trut et al., 2009). Wilkins et al. (2014) notaram que, assim como a adrenal, todos os caracteres ligados à domesticação (compondo a chamada "Síndrome de domesticação") estão ligados ontogeneticamente ao desenvolvimento de células da crista neural. Assim, a redução do efeito destas células no desenvolvimento (seja por redução de migração das células, ou de efeitos de expressão local) poderia explicar as diversas modificações observadas em animais domesticados. Então, a modificação de caracteres da face em animais domesticados pode se dar por resposta indireta à seleção para maior docilidade, através da diminuição da glândula adrenal, mediada pela redução da influencia de células da crista neural (Wilkins et al., 2014). Apesar de evolução correlacionada de caracteres ser comum na maioria das espécies domesticadas ("Síndrome de domesticação"), Canidae (tanto cachorros quanto raposas) é o grupo que apresenta um padrão de modificações 


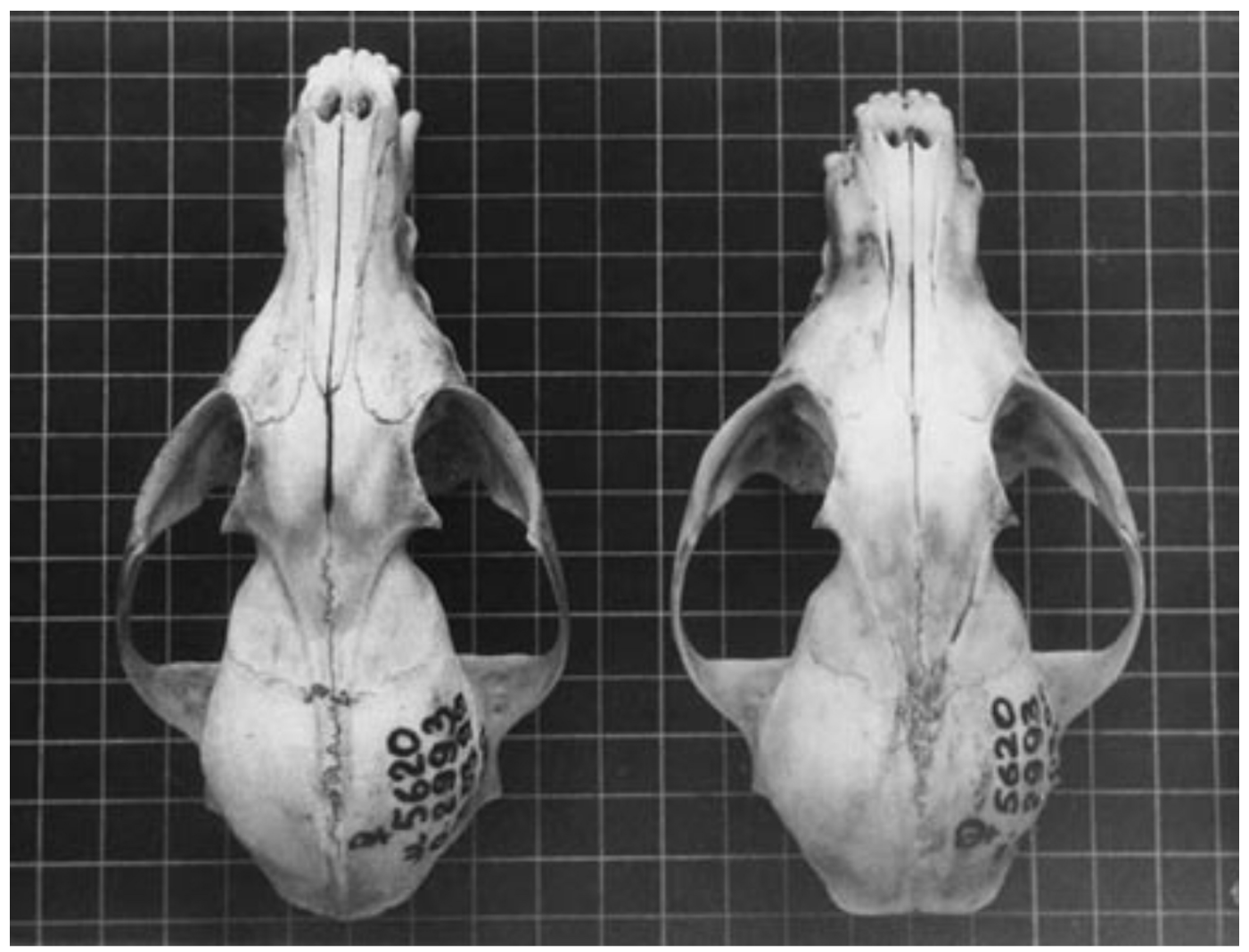

Figura 5.1: Crânio de indivíduos selvagens (esquerda) e domesticados (direita) de Vulpes vulpes. Reproduzido de Trut et al. (2004).

que podem ser consistentemente correlacionadas com o desenvolvimento da crista neural (Sanchez-Villagra e Geiger, 2016). Uma maior variabilidade genética associada à genes regulatórios ligados à crista neural pode ajudar a explicar porque canídeos são mais variáveis em sua morfologia craniana.

Apesar dos canideos selvagens viventes apresentarem certa conservação morfológica, táxons extintos apresentavam morfologias e hábitos de vida extremamente variados (Slater, 2015). A diversidade fenotípica em táxons fosseis pode ser tão extrema a ponto de produzir morfologias similares às encontradas em cachorros domésticos atuais (e.g. Figura 5.2), o que é particularmente impressionante, visto que cachorros domésticos são um exemplo de diversidade morfológica extrema (e.g. Drake e Klingenberg, 2010). Isso sugere que, de acordo com os resultados encontrados aqui, a maleabilidade morfológica de $C$. familiaris provavelmente esteve presente em toda a 
diversificação de Canidae, apenas sendo coaptada recentemente para a produção de variantes domésticos. Assim, a investigação da domesticação de cachorros, e do registro fossil podem ser fontes valiosas de informação para a compreensão da evolução de Canidae (Fondon e Garner, 2004; Laidlaw et al., 2007; Sanchez-Villagra e Geiger, 2016).

\section{Testes de Deriva no Contexto de Métodos Filoge-} néticos Comparativos

Os anos recentes tem visto um número crescente de Métodos Filogenéticos Comparativos para o estudo de padrões macroevolutivos. Essa tendência tem em parte sido estimulada pelo crescimento do poder de computadores pessoais e pelo acesso a plataformas de programação versáteis, como o R ( $\mathrm{R}$ Core Team, 2016). Isso tem encurtado o caminho entre desenvolvimentos teóricos e implementação de software, com muitos artigos sobre novos métodos sendo publicados em conjunto com implementações prontas para o uso. Entretanto, uma base teórica sólida nem sempre é o suficiente para contornar problemas de implementação e a interação dos métodos com os dados. A avaliação dos méritos e limitações de diferentes métodos e implementações, até para os classicamente estabelecidos, é essencial para o progresso do ramo de análises comparativas (Cooper et al., 2016).

Aqui eu apresentei uma investigação das propriedades estatísticas de dois métodos baseados em teoria de genética quantitativa, o de regressão e o de correlação, para o teste da hipótese de evolução neutra (Capítulo 4). Ambos os métodos se baseiam na predição teórica de que padrões de covariação intraespecíficos e interespecíficos vão ser similares sob deriva (Lande, 1979). A rejeição dessa expectativa pode ser vista como evidência de que o padrão observado não se adequa a expectativa sob deriva, abrindo 

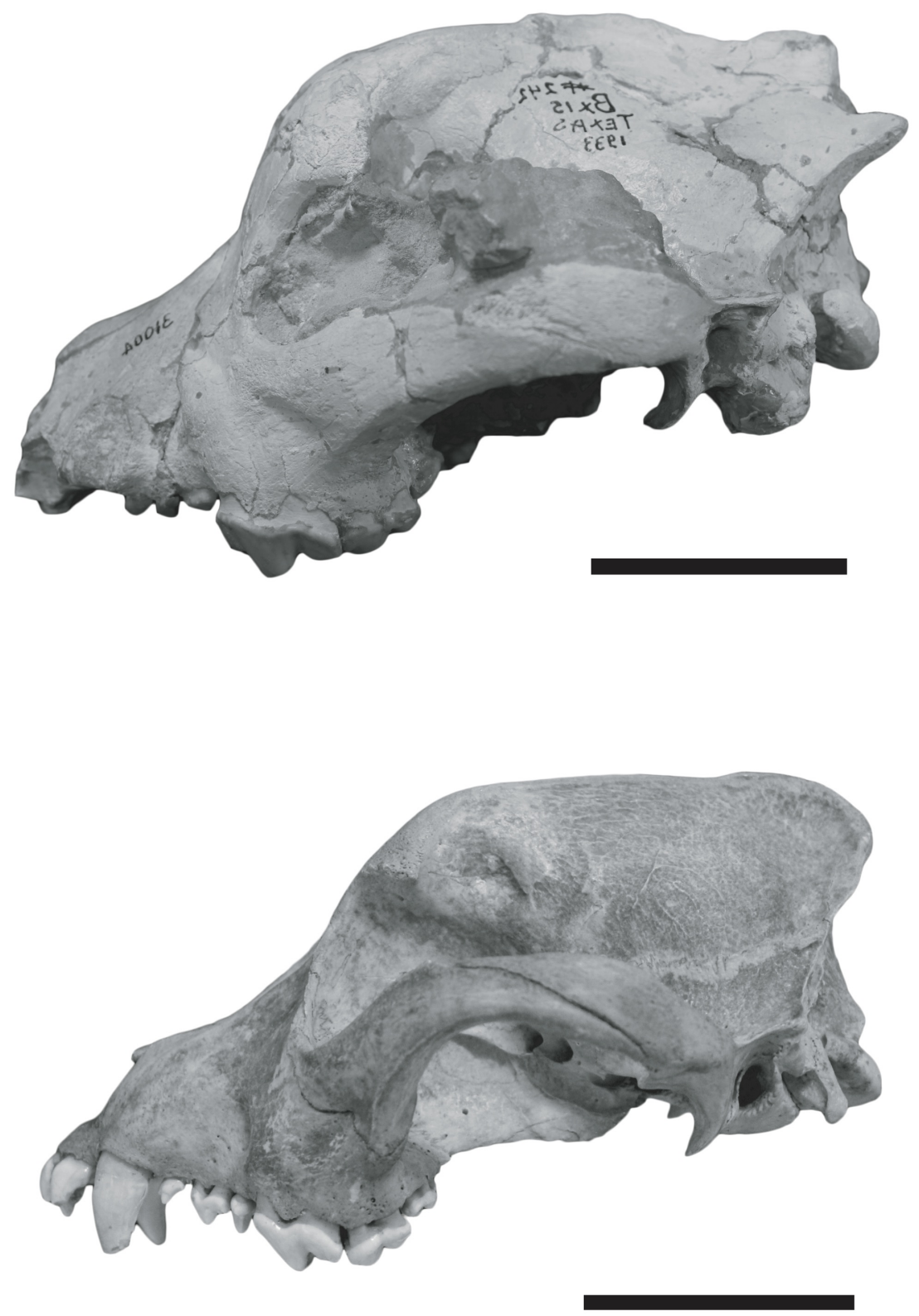

Figura 5.2: Comparação dos crânios de C. familiaris e Borophagus secundus (F:AM31004). Escala $=5 \mathrm{~cm}$. 
a porta para seleção natural como uma hipótese explicativa (Ackermann e Cheverud, 2002, 2004; Marroig e Cheverud, 2004)

A utilização de contrastes filogenéticos independentes (PIC) claramente melhoram a performance de ambos os testes, sendo mandatório no caso do teste de correlação. Isso pode ter um impacto significativo para conclusões de trabalhos baseados neste ultimo método (e.g. Ackermann e Cheverud, 2002; Marroig e Cheverud, 2004), uma vez que a dependência filogenética entre as linhagens introduz correlação entre os fenótipos dos descendentes mesmo sob deriva. Por outro lado, o teste de regressão pode ser adequado sem o uso de informação filogenética através do PIC. Esse teste entretanto só apresenta erro do tipo I adequado para um número de espécies elevado, fato este que pode influenciar a conclusão de trabalhos baseados em amostras reduzidas (e.g. Ackermann e Cheverud, 2004; Schroeder et al., 2014).

Os resultados das simulações indicam ainda que não parece existir uma sugestão única para os interessados no estudo de evolução multivariada. Enquanto o teste de correlação apresenta erros do tipo I adequados para quase todos os números amostrais de espécie, ele é bastante impactado por potenciais flutuações no numero efetivo populacional $\left(N_{e}\right)$ das espécies. Esse problema é provavelmente contornável em clados mais inclusivos, por terem tido tempo o suficiente de atingir equilíbrio entre mutação e deriva (Lande, 1979, 1980; Felsenstein, 1988; Lynch, 1989; Hansen e Martins, 1996). Porém, a medida que clados se tornam menores e mais jovens, este problema pode afetar substancialmente a conclusão deste teste. $\mathrm{O}$ teste de regressão, por outro lado, é mais robusto a variações de $N_{e}$, o que poderia torna-lo indicado para populações recentes. Esse teste, entretanto, apresenta erro do tipo I inflado quando poucas espécies são analisadas, podendo impedir o uso de ambos os testes em clados pequenos e jovens. $\mathrm{O}$ erro do tipo I inflado para o teste de regressão pode de certa forma ser contornado 
pela exclusão de componentes principais de menor importância. Essa prática porém leva a uma queda do poder, o que pode impedir a detecção do sinal de seleção natural, o que também é potencialmente problemático em clados menores. Visto isso, os testes de regressão e deriva, quando empregados com cautela, podem ser ferramentas valiosas no estudo da evolução fenotípica multivariadas.

As técnicas aqui apresentadas diferem dos demais métodos comparativos pois não requerem nenhuma hipótese explicita a respeito de que tipo de fatores podem estar influenciando a evolução adaptativa do grupo. Assim, não é necessária a proposição de nenhum tipo de "nicho"ou "zona adaptativa"(e.g. Hansen, 1997; Butler e King, 2004), ou de variáveis independentes (e.g. Felsenstein, 1985; Grafen, 1989; Martins e Hansen, 1997; Hansen et al., 2008), permitindo a investigação da evolução fenotípica até mesmo quando o conhecimento a respeito do grupo é limitado. Ainda, estas tecnicas não são inconsistentes com os tipos de métodos supracitados, podendo ser utilizados em conjunto para uma melhor exploração de hipóteses evolutivas (e.g. Simon et al., 2016).

Cada teste individual ainda apresenta peculiaridades vantajosas. O teste de regressão pode ser aplicado na ausência de informação filogenética (desde que seja ajustado o número de componentes principais), o que pode ser particularmente vantajoso em grupos sem informação filogenética precisa, como grupos fósseis. O teste de correlação, por outro lado, apresenta erro do tipo I adequados até mesmo para número de espécies muito baixos, permitindo a análise de dados com alta dimensionalidade até com clados pequenos. Assim, estas técnicas constituem um recurso pouco apreciado e com um grande potencial para a análise de dados multivariados. 


\section{Perspectivas}

Os resultados da presente tese abrem dois tipos de possíveis linhas de investigação sendo um de natureza metodológica e outro de natureza empírica. Do ponto de vista metodológico as possibilidades ainda são diversas. O método de simulação filogenética empregado aqui é plastico o suficiente para expandir o arcabouço de hipóteses que podem ser explorados pelos testes de deriva. De fato, a simulação permite a construção da distribuição de estatísticas referentes à hipótese nula, mas nada nos impede de construir distribuições referentes a outras hipóteses. Isso pode ser feito não apenas alterando o padrão de seleção diretamente como um parâmetro nas equações de genética quantitativa (Equação 4.5), mas também simulando outros padrões de seleção através da modificação dos tamanhos de ramos nas árvores (Venditti et al., 2011; Baker et al., 2016). Outras direções são ainda possíveis, como a avaliação do impacto de extinções, da inclusão de espécies fósseis e de erro na estimativa da filogenia.

Em termos de questões empíricas, as considerações colocadas acima sobre o Capítulo 3 delineiam uma possível linha de pesquisa relacionada a origem da diferença em padrão de integração morfológica em Canidae, e suas possíveis interconexões com o processo de domesticação e com o registro fóssil. Ainda do ponto de vista empírico, o Capítulo 3 levanta duas possíveis lacunas de conhecimento ligadas às famílias dos cangambás (Mephitidae) e dos ursos (Ursidae). Os testes sob contrastres para ambos os grupos falharam em rejeitar a hipótese de deriva, o que levanta possibilidades sobre como esses animais se adaptaram para suas diferentes dietas atuais. Visto que ambos grupos apresentam amostras reduzidas, fato que também pode ter afetado estes resultados, a avaliação de espécies fósseis pode ser essencial para aumentar o poder dos testes e esclarecer essas questões.

Por último, análises mais aprofundadas sobre a evolução dos Carnivora 
ainda são necessários. A inclusão, na presente tese, dos dados de Feliformes provenientes da dissertação de mestrado de Zahn (2016) foram essenciais para diagnosticar com clareza a distinção de Canidae dos demais Carnivora, porém muitas relações ainda ficam em aberto. Inclusive, análises preliminares de Zahn (2016) demostraram diversas associações entre integração morfológica e fatores ecológicos que merecem uma melhor investigação em um contexto mais amplo. 


\section{Referências Bibliográficas}

Ackermann, R. R. e Cheverud, J. M. (2002). Discerning evolutionary processes in patterns of tamarin (genus Saguinus) craniofacial variation. American Journal of Physical Anthropology, 117(3):260-271.

Ackermann, R. R. e Cheverud, J. M. (2004). Detecting genetic drift versus selection in human evolution. Proceedings of the National Academy of Sciences of the United States of America, 101(52):17946-17951.

Baker, J., Meade, A., Pagel, M., e Venditti, C. (2016). Positive phenotypic selection inferred from phylogenies. Biological Journal of the Linnean Society, 118(1):95-115.

Belyaev, D. K., Plyusnina, I. Z., e Trut, L. N. (1985). Domestication in the silver fox (Vulpes fulvus Desm): Changes in physiological boundaries of the sensitive period of primary socialization. Applied Animal Behaviour Science, 13(4):359-370.

Butler, M. A. e King, A. (2004). Phylogenetic comparative analysis: a modeling approach for adaptive evolution. The American Naturalist, 164(6):683695.

Cheverud, J. M. (1996). Developmental integration and the evolution of pleiotropy. Integrative and Comparative Biology, 36:44-50.

Cooper, N., Thomas, G. H., e FitzJohn, R. G. (2016). Shedding light on the 'dark side' of phylogenetic comparative methods. Methods in Ecology and Evolution, 7(6):693-699.

Drake, A. e Klingenberg, C. P. (2008). The pace of morphological change: historical transformation of skull shape in St Bernard dogs. Proceedings of the Royal Society of London. Series B, Biological Sciences, 275(1630):71-76.

Drake, A. G. e Klingenberg, C. P. (2010). Large-Scale Diversification of Skull Shape in Domestic Dogs: Disparity and Modularity. 175(3):289-300.

Felsenstein, J. (1985). Phylogenies and the comparative method. The American Naturalist, 125(1):1-15.

Felsenstein, J. (1988). Phylogenies and quantitative characters. Annual Review of Ecology and Systematics, 19:445-471.

Fondon, J. e Garner, H. (2004). Molecular origins of rapid and continuous morphological evolution. Proceedings of the National Academy of Sciences of the United States of America, 101(52):18058-18063.

Grafen, A. (1989). The Phylogenetic Regression. Philosophical Transactions of the Royal Society B: Biological Sciences, 326(1233):119-157. 
Hansen, T. (1997). Stabilizing selection and the comparative analysis of adaptation. Evolution, 51(5):1341-1351.

Hansen, T., Pienaar, J., e Orzack, S. (2008). A comparative method for studying adaptation to a randomly evolving environment. 62(8):19651977.

Hansen, T. F. e Martins, E. (1996). Translating between microevolutionary process and macroevolutionary patterns: the correlation structure of interspecific data. Evolution, 50(4):1404-1417.

Kukekova, A. V., Oskina, I. N., Kharlamova, A. V., e Chase, K. (2008). Fox farm experiment: hunting for behavioral genes. Vestnik VOGiS, 12(1/2):50-62.

Laidlaw, J., Gelfand, Y., Ng, K. W., Garner, H. R., Ranganathan, R., Benson, G., e Fondon, J. W. (2007). Elevated Basal Slippage Mutation Rates among the Canidae. Journal of Heredity, 98(5):452-460.

Lande, R. (1979). Quantitative genetic analysis of multivariate evolution, applied to brain: body size allometry. Evolution, 33(1):402-416.

Lande, R. (1980). Genetic variation and phenotypic evolution during allopatric speciation. The American Naturalist, 116(4):463-479.

Lynch, M. (1989). Phylogenetic hypotheses under the assumption of neutral quantitative-genetic variation. Evolution, 43(1):1-17.

Marroig, G. e Cheverud, J. M. (2004). Did natural selection or genetic drift produce the cranial diversification of neotropical monkeys? The American Naturalist, 163(3):417-428.

Martins, E. e Hansen, T. (1997). Phylogenies and the comparative method: a general approach to incorporating phylogenetic information into the analysis of interspecific data. The American Naturalist, 149(4):646-667.

R Core Team (2016). R: A Language and Environment for Statistical Computing.

Sanchez-Villagra, M. R. e Geiger, M. (2016). The taming of the neural crest: a developmental perspective on the origins of morphological covariation in domesticated mammals. Royal Society Open Science, 3(6):160107.

Schroeder, L., Roseman, C. C., Cheverud, J. M., e Ackermann, R. R. (2014). Characterizing the Evolutionary Path(s) to Early Homo. PLOS ONE, 9(12):e114307.

Simon, M. N., Machado, F. A., e Marroig, G. (2016). High evolutionary constraints limited adaptive responses to past climate changes in toad skulls. Proceedings of the Royal Society of London. Series B, Biological Sciences, 283:110. 
Slater, G. J. (2015). Iterative adaptive radiations of fossil canids show no evidence for diversity-dependent trait evolution. Proceedings of the National Academy of Sciences of the United States of America, 112(16):4897-4902.

Trut, L. (1999). Early canid domestication: The farm-fox experiment foxes bred for tamability in a 40-year experiment exhibit remarkable transformations that suggest an interplay between behavioral genetics and development. American Scientist, 87(2):160-169.

Trut, L., Oskina, I., e Kharlamova, A. (2009). Animal evolution during domestication: the domesticated fox as a model. BioEssays, 31(3):349-360.

Trut, L. N., Plyusnina, I. Z., e Oskina, I. N. (2004). An Experiment on Fox Domestication and Debatable Issues of Evolution of the Dog. Russian Journal of Genetics, 40(6):644-655.

Venditti, C., Meade, A., e Pagel, M. (2011). Multiple routes to mammalian diversity. Nature, 479(7373):393-396.

Wayne, R. (1986). Cranial morphology of domestic and wild canids: the influence of development on morphological change. Evolution, 40(2):243261.

Wilkins, A. S., Wrangham, R. W., e Fitch, W. T. (2014). The "Domestication Syndrome"in Mammals: A Unified Explanation Based on Neural Crest Cell Behavior and Genetics. Genetics, 197(3):795-808.

Zahn, T. M. G. (2016). Integração morfológica no crânio e evolução da morfologia craniana em Feliformia (Carnivora: Mammalia). Master's thesis. 

Apêndices 

Apêndice A

Espécimes 


\author{
Sexo \\ o" Machos \\ † Fêmeas \\ ○ Sexo indefinido
}

\title{
Museu
}

AMNH American Museum of Natural History (Nova York, Estados Unidos)

ANSP Academy of Natural Sciences of Drexel University (Philadelphia, Estados Unidos)

FCNyM Faculdad de Ciencias Naturales y Museo de La plata (La Plata, Argentina)

FMNH Field Museum of Natural History (Chicago, Estados Unidos)

MACN Museo Argentino de Ciencias Naturales Bernardino Rivadavia (Buenos Aires, Argentina)

MCZ Museum of Comparative Zoology (Cambridge, Estados Unidos)

MN Museu Nacional (Rio de Janeiro, Brasil)

MPEG Museu Paraense Emilio Goeldi (Belém, Brasil)

MZUSP Museu de Zoologia da Universidade de São Paulo (São Paulo, Brasil)

USNM National Museum of Natural History of the Smithsonian Institution (Washington, Estados Unidos)

\section{Canidae}

Atelocynus microtis - FMNH 980800", FMNH 939550", FMNH 524910, FMNH 980810", FMNH 60676o, FMNH 110949o", FMNH 606740", FMNH 578360, FMNH 60675\%, MN 650。, MPEG 88660, MPEG 42600", MPEG 8540, MPEG 6541, MPEG 4252ᄋ, MPEG 65400", MVZ 136657o", MVZ 1579780", MZUSP 197510", MZUSP 197530", MZUSP 4320o, MZUSP 19750॰, MZUSP 197540".

Canis adustus - AMNH 2163440", AMNH 116335\%, AMNH 52049o", AMNH 81039\%, AMNH 160990\%, AMNH 1163330", AMNH 160989o, AMNH 160997\%, AMNH 116334\%, AMNH 1142550", AMNH 114259\%, AMNH 54212q, AMNH 27725\%, AMNH 1791360", AMNH 520570", FMNH 27248\%, FMNH 329360", FMNH 83641。, FMNH 189390", FMNH 189480", FMNH 421210", FMNH 381840", FMNH 38185o, FMNH 95999o, FMNH 73036\%, FMNH 959330", FMNH 73037\%, MCZ 44289o, MCZ 44290o", MCZ37939o, MCZ 45890。, MVZ 149525o", MVZ 
1555640", MVZ 1184150", MVZ 1495240", USNM 617590", USNM 470131\%, USNM 399437"', USNM 1823430", USNM 181488, USNM 182348", USNM 1621370", USNM 3500710", USNM 318095\%, USNM 299841\%, USNM 350072\%, USNM 342087\%, USNM 3420850", USNM 342088\%.

Canis anthus - AMNH 810410", AMNH 81040\%, AMNH 27726\%, AMNH 27732\%, AMNH 27735\%, AMNH 27733\%, AMNH 27739\%, AMNH 1877140", AMNH 1141750", FMNH 271550", FMNH 271470", FMNH 27152ᄋ, FMNH 271560", FMNH 27150"', MVZ 101014\%, MVZ 173749 1401160", FMNH 1073400", FMNH 107231\%, FMNH 107227q, FMNH 107234q, FMNH 1072320", FMNH 107337\%, FMNH 107230", FMNH 107338@, FMNH 1073360", FMNH 140115\%, FMNH 121349q, FMNH 107228"', FMNH 107229q, FMNH 140119"', FMNH 107236", FMNH 140118@, FMNH 105807"', FMNH 1401170", FMNH 105742o, FMNH 1067230", FMNH 1067220", FMNH 105740o, FMNH 1057440", FMNH 1067240", FMNH 1057410", FMNH 105743o, FMNH 1083640", FMNH 1401240", FMNH 1072230", FMNH 756470", FMNH 98921, FMNH 899670", FMNH 89966\%, FMNH 107226o, FMNH 1401220, FMNH $962330^{\circ}$.

Canis aureus - AMNH 88708\%, AMNH 887090", AMNH 887120", AMNH 545160", AMNH 54515q, FMNH 103912q, FMNH 103913q, FMNH 103914q, FMNH 103920o, FMNH 103910\%, FMNH 103916q, FMNH 29757\%, FMNH 297900", FMNH 29756o, FMNH 103909"', FMNH 1123710", FMNH 1123640", FMNH 572640", FMNH 97773o, FMNH 1123720", FMNH 356720", FMNH 830760", FMNH 83078q, FMNH 91242@, MZUSP 2568q, AMNH 169447q, FMNH 27158?.

Canis dingo - AMNH 1977470", AMNH 197746\%, AMNH 1977480", AMNH

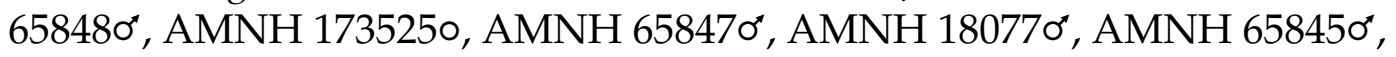
AMNH 658460, AMNH 1834340", AMNH 183433o, AMNH 153629o, AMNH 1544650", AMNH 153664o, AMNH 153663o, FMNH 129799"', FMNH 33598\%, FMNH 1198510", FMNH 542030", MCZ 329", MCZ 80250", MCZ 21590@, MCZ 213910", MCZ 21593o, MCZ 280260", MCZ 47062o, MCZ 21591o, MVZ 119676@, MVZ 1196750", MVZ 119812@, MVZ 152803@, MVZ 175994ه", MVZ 133283\%, MVZ 124399\%, MVZ 1293060", MVZ 129305\%, MVZ 1196770", MVZ 1528040", USNM 284435\%, USNM 2703810", USNM 238468\%, USNM 1970760", USNM 284437\%, USNM 254718\%, USNM 277393 151842\%, AMNH 104074\%, AMNH 151839", AMNH 151803\%, AMNH 1518410".

Canis familiaris - USNM 175867@, USNM 2899720, USNM 38989o, USNM

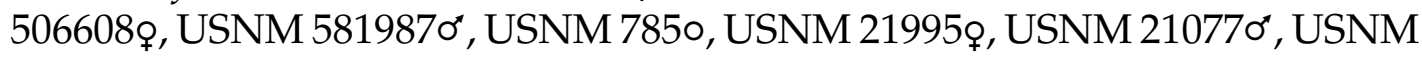
219890", USNM 289968" , USNM 582945\%, USNM 2008880, USNM 785०, USNM 289967@, USNM 220440", USNM 2899730, USNM 2411370", USNM 349500\%, USNM 22194。, USNM 221410, USNM 122748\%, USNM 124645o, USNM 273290。", USNM 187987\%, USNM 272209\%, USNM 369670", USNM 6610。, USNM 22308。, USNM 66110, USNM 22690。, USNM 275155。, USNM 274104。, USNM 3476080, USNM 8222。, USNM 66120, USNM 2610350", USNM 348050", USNM 208050, USNM 174670。, USNM 22252o, USNM 225580, USNM 122751o, USNM 122759\%, USNM 232240", USNM 360730, USNM 219920, USNM 219980", USNM 225630, USNM 16532o, USNM 2899710, USNM 23005o, USNM 1227490", USNM 
1879840", USNM 21630, USNM 35140@, USNM 219940, USNM 2701720", USNM 122750 "', USNM 1879880", USNM 2693210", USNM 1879820, USNM 2514430", USNM 86370@, USNM 211350", USNM 1879760", USNM 187977@, USNM 1879800", USNM 219930", USNM 21997o, USNM 219880", USNM 15431。, USNM 518126。, USNM 514513。, USNM 5342810", USNM 505225。, USNM 399050œ, USNM 2899760", USNM 398215\%, USNM 398908。, USNM 289977\%, USNM 2381680", USNM 347480。, USNM 396991。, USNM 399049o, USNM 347609\%, USNM 347441\%, USNM 3985360", USNM 350000。.

Canis himalayensis - ANSP 174980", ANSP 174970", ANSP 174960, MCZ 24870。, MCZ 248730", USNM 172654o, USNM 198458, USNM 198460, USNM 172655\%, USNM 198457o".

Canis indica - FMNH 444690", FMNH 44467\%, FMNH 44471\%, FMNH 44470。, FMNH 46079o, FMNH 99417o.

Canis latrans - MN 32369o, MVZ 36167\%, MVZ 35445\%, MVZ 354460", MVZ 37959o", MVZ 35447o", MVZ 35443o, MVZ35444o, MVZ112798@, MVZ 112799\%, MVZ 35442o", MVZ 37962o, MVZ 3245\%, MVZ 37961o", MVZ3247o", MVZ 32460", MVZ 37960, MVZ 40173, MVZ 40174요, MVZ 36469, MVZ 441680", MVZ 106928o, MVZ 704690", MVZ 975940", MVZ 97599o, MVZ 97598\%, MVZ 975970", MVZ 1840440", MVZ 97595\%, MVZ 975960", MVZ 214140", MVZ 70500@, MVZ 21545o", MVZ 107350o", MVZ 16260o", MVZ 21410\%, MVZ 70501, MVZ 21547o", MVZ 25899o", MVZ 70499o", MVZ 21546o, MVZ 107247o", MVZ 343070", MVZ 704980", MVZ 704700", MVZ 704720", MVZ 704710", MVZ 16256o, MVZ 519780", MVZ128760", MVZ 16258\%, MVZ34755o, MVZ37284o", MVZ 51660@, MVZ 16257@, MVZ 8260o", MVZ 849610", MVZ 37292o", MVZ 51623, MVZ 880640", MVZ 37294o", MZUSP 2570。, MZUSP 28846o.

Canis lupus - FMNH 7657o, FMNH 7619\%, FMNH 21750。, FMNH 217510", FMNH 1287940", FMNH 1387900", FMNH 138795o, FMNH 1387730", FMNH 138783o, FMNH 138774o, FMNH 1387720", FMNH 138779o, FMNH 138782o, FMNH 138781o, FMNH 137780", FMNH 138784o, FMNH 128780 $0^{\circ}$, FMNH 138785o, FMNH 1387920", FMNH 138787 $0^{\circ}$, FMNH 1387930", FMNH 138788。, FMNH 138789o, FMNH 138791\%, FMNH 1387860", FMNH 1387970", FMNH 150997\%, FMNH 729610", FMNH 72962o, MCZ 39658\%, MCZ 505080", MN 323660", MVZ 83210", MVZ 59682o, MVZ 1096150", MVZ 56810", MVZ 324220", MVZ 573430", MVZ 35380。, MVZ 76253, MVZ 1292540", MVZ 47276ᄋ, MVZ 472777\%, MVZ 74827\%, MVZ 138927o", MVZ 748280", MVZ 31973 - Bơ", MVZ 1096140", MVZ 74829@, MVZ 109617ه", MVZ 35387o", MVZ 353810", MVZ 31042o, MVZ 310430", MVZ 124540", MVZ124550", MVZ 12457o", MVZ342280", MVZ 28003o, MVZ 28004, MVZ 280010", MVZ 28002o", MVZ 29772o, MVZ 305150", MVZ 312340", MVZ 184046o, MVZ 159321。, MVZ 762540", MVZ 951770", MVZ 99746。, MVZ 4777o", MVZ 441660", MVZ 47760", MVZ 184047。, MVZ 9840", MVZ 773450", MVZ 123980@, MVZ 773460", MVZ 777420", MVZ 119835\%, MVZ 88226ᄋ, MVZ 882250", MVZ 1239780", MVZ 1198330", MVZ 84200\%, MVZ 119834, MVZ 1198360", MVZ 119832o, MVZ 125603\%, MVZ 123999o", MVZ 122232。, MVZ 1239810", MVZ 123983@, MVZ 125604o", MVZ 1239820", MVZ 125607o", MVZ 122234o", MVZ 125606, MVZ 122233o, MVZ 1222300", MVZ 1222310", MVZ 1281140", MVZ 2243920", MVZ 171944ㅇ, MVZ 
333890", MVZ 1840480", MZUSP 25690".

Canis lycaon - ANSP 2262o, ANSP 22610, ANSP 2259o, FMNH 1292950", FMNH 1292940", FMNH 21207o, FMNH 153798。, FMNH 1476360", FMNH 147637o, FMNH 1476380", FMNH 147639o, FMNH 1601080", FMNH 1476400", FMNH 153802o, FMNH 1408940", FMNH 1653520", FMNH 1601060", FMNH 153799 "', FMNH 1601100", FMNH 160107o, FMNH 51773。, MCZ 8045。, MCZ 3260, MCZ 51378, MCZ 409360, MCZ 56610, MCZ 566110", MCZ 56612。, MCZ 62506。, USNM 1405620", USNM 1405610", USNM 2681940, USNM 170566。, USNM 168820。, USNM 223171\%, USNM 242289o", USNM 242290。, USNM 1807980, USNM 1706920", USNM 170621。, USNM A45561。, USNM A45560。, USNM 289995ᄋ, USNM 2650710", USNM 2433950", USNM 347917@, USNM 265072o, USNM 178452。, MVZ 773440", MVZ 123562o", MVZ 77342@, MVZ $773430^{\prime \prime}$.

Canis mesomelas - AMNH 37700", AMNH 233009 ", AMNH 806520", AMNH 233010॰, AMNH 27736\%, AMNH 277310", AMNH 347310", AMNH 347340", AMNH 347320", AMNH 187716 , AMNH 1142670", AMNH 187727@, AMNH 54208。, AMNH 542110", AMNH 542130", AMNH 542060", AMNH 179139 $0^{\circ}$, AMNH 1791370", AMNH 179140\%, AMNH 542090", AMNH 169095。, AMNH 1141770", AMNH 82398\%, AMNH 114179\%, AMNH 114180\%, AMNH 2051450", AMNH 205146\%, AMNH 1877150", AMNH 187711。, AMNH 1142280", AMNH 187713o, AMNH 1877120", MVZ117811, MVZ 117810。, MVZ 117808。, MVZ 118420\%, MVZ 118419ᄋ, MVZ 117809o", MVZ 165153\%, MVZ 1651560", MVZ 1651420", MVZ 1651410", MVZ1178070", MVZ 1178020", MVZ 1184160", MVZ 165152o, MVZ 1651157o, MVZ 165154ㅇ, MVZ 1651580", MVZ 165150。, MVZ 165140。, MVZ 165151\%, MVZ 1651450", MVZ 1651430", MVZ 165147o", MVZ 1651460", MVZ 993980, MZUSP 25710.

Canis rufus - AMNH 5450/4609o", AMNH 100225\%, MVZ 95809\%, MNHN 235608\%, MNHN 235607\%, MNHN 2355940", MNHN 2344380", MNHN 2356120", MNHN 235595。, MNHN 235596॰, MNHN 234417 "', MNHN 2356110", MNHN 235613。, MNHN 235609 ", MNHN 235599, MNHN 235598@, MNHN 235597o", MNHN 2356100", MNHN 236536o, MNHN 2356160", MNHN 235614。, MNHN 236542o, MNHN 236541, MNHN 236539o", MNHN 236538, MNHN 236547q, MNHN 236546\%, MNHN 236545\%, MNHN 2365440", MNHN 236543\%, MNHN 236552q, MNHN 236551\%, MNHN 236550 o", MNHN 236549q, MNHN 236548q, MNHN 242557。, MNHN 242556。, MNHN 242555 "', MNHN 2425540", MNHN 236554, MNHN 2425630", MNHN 2425620", MNHN 242560q, MNHN 242559\%, MNHN 2425680", MNHN 242567\%, MNHN 242566\%, MNHN 242565\%, MNHN 2425640 ".

Canis simensis - AMNH NA(214799), AMNH 214798\%, AMNH 810010", FMNH 8170 o", FMNH 27010o, FMNH 28492o, FMNH 27012o, FMNH 32940o", FMNH 270110", MCZ 382890".

Cerdocyon thous - MZUSP 2480॰, MZUSP 2470。, MZUSP 3340。, MZUSP 31030", MZUSP 66360", MZUSP 24810, MZUSP 2478。, MZUSP 3183॰, MZUSP 4152o, MZUSP 2476o, MZUSP 197410", MZUSP 24720", MZUSP 2917o", MZUSP 486o, MZUSP 487o", MZUSP 11650", MZUSP 2831。, MZUSP 8903०, MZUSP 8560", MZUSP 11640", MZUSP 41350", MZUSP 11660, MZUSP 29019०, MZUSP 
2919\%, MZUSP 31060。, MZUSP 2833\%, MZUSP 2835\%, MZUSP 2831\%, MZUSP 3763o, MZUSP 3762o, MZUSP 453o, MZUSP 28340", MZUSP 13797\%, MZUSP 9011\%, MZUSP 32617\%, MZUSP 3097\%, MZUSP 30370", MZUSP 3038", MZUSP 30410", MZUSP 42200", MZUSP 3030 $\%$, MZUSP 3040\%, MZUSP 31020", MZUSP 3045o, MZUSP 29180", MZUSP 2922。, MZUSP 29210, MZUSP 31010", MZUSP 3031" , MZUSP 3486", MZUSP 19739"', MZUSP 3100", MZUSP 30330", MZUSP 3034 3042@, MZUSP 3035"', MZUSP 6640。, MZUSP 42160", MZUSP 42170", MZUSP 197420", MZUSP 19738॰, MZUSP 37770", MZUSP 42150", MZUSP 4221。, MZUSP 7028", MZUSP 33720", MZUSP 33730", MZUSP 63150", MZUSP 197570", MZUSP 2599\%, MZUSP 26010", MZUSP 2600", MZUSP 2595\%, MZUSP 2602\%, MZUSP 35040", MZUSP 2598\%, MZUSP 25960", MZUSP 63140", MZUSP 1933\%, MZUSP 19793\%, MZUSP 9686"', MZUSP 87320", MZUSP 2757o, MZUSP 19755\%, MZUSP 5180", MZUSP 5140".

Chrysocyon brachyurus - FCNyM 2.IV.02.40, FCNyM 16860", FCNyM 5.X.99.10, FCNyM 1684o, FCNyM 564o, FCNyM 6950, FCNyM 60, FCNyM 2024\%, MACN 242010, MACN 240430, MACN 239830, MACN 191460, MACN 3710, MACN 5349o, MACN 30198", MACN 3730, MACN 239840, MACN 206460, MACN 3029o, MACN 234560, MACN 13466o, MN 3041o, MN 709990", MN 69817\%, MN 710860", MN 68175o, MN 4815o, MN 366660, MN 4899\%, MN 69817\%, MN 709990", MN 710860", MN 640。, MN 664o, MN 175010", MN 1049o, MN 175020, MPEG 1419o, MVZ 120924, MVZ 1195660", MZUSP 32629\%, MZUSP 32505o, MZUSP 34774o, MZUSP 3090\%, MZUSP 32041\%, MZUSP 32044o, MZUSP 32503०, MZUSP 32042o, MZUSP 320430", MZUSP 19733\%, MZUSP 525o, MZUSP 321990", MZUSP 320390", MZUSP 320560, MZUSP 319810, MZUSP 28870\%, MZUSP 94200", MZUSP 197320, MZUSP 2479o, MZUSP 3025\%, MZUSP 3700॰, MZUSP 33380", MZUSP 197360.

Cuon alpinus - AMNH 607750, AMNH 54544, AMNH 548420, AMNH 549840", AMNH 1018820", AMNH 101773\%, AMNH 102083\%, ANSP 152760", ANSP 17499o, FMNH 360010", FMNH 33500。, FMNH 91246"', FMNH 39182。, FMNH 358140", FMNH 35813o, MCZ 195660, MCZ 303820, MCZ 359290", MCZ 35919\%, MNHN 835220", MNHN 1969760.

Lycalopex culpaeus - FCNyM 5.III.36.9\%, FCNyM 1620o, FCNyM 1749o", MACN 150960", MACN 15090ф, MACN 150920", MACN 15112q, MACN 151070", MACN 15097\%, MACN 151020", MACN 15105\%, MACN 151100", MACN 15115\%, MACN 150860", MACN 15114\%, MACN 150990", MACN 15093\%, MACN 150850", MACN 15095\%, MACN 15104, MACN 151080", MACN 15088\%, MACN 15098\%, MACN 151010", MACN 15106\%, MACN 15056\%, MACN 150530", MACN 15068@, MACN 150590", MACN 150810", MACN 150840", MACN 150700", MACN 15076ᄋ, MACN 150690", MACN 15073q, MACN 150820", MACN 15083q, MACN 150540", MACN 15067" , MACN 15077\%, MACN 15235\%, MACN 2229", MACN 15238", MACN 15221 \%.

Lycalopex fulvipes - FMNH 23814\%, FMNH 238150".

Lycalopex griseus - FCNyM 1892o, FCNyM 1889o, FCNyM 1903o, FCNyM 18900, FCNyM 1893o, FCNyM 7120", FCNyM 4510, FCNyM 21.XII.01.27o, FCNyM 1899o, FCNyM 19010, FCNyM 240。, FCNyM 559o, FCNyM 441。, 
FCNyM 7010, FCNyM 6960, MACN 20208q, MACN 50419q, MACN 50420q, MACN 50490\%, MACN 152630", MACN 152620", MACN 15269ᄋ, MACN 152650", MACN 14540"', MACN 15264o, MACN 151860", MACN 15189"', MACN 208140", MACN 13781\%, MACN 20206\%, MACN 20205\%, MACN 20207o", MACN 36480ø, MACN 2320 o", MACN 20278\%, MACN 23728\%, MACN 741, MACN 23663o, MACN 236620", MACN 23729․

Lycalopex gymnocercus - MACN 27530", MACN 54133q, MACN 14409\%, MACN 15390\%, MACN 153890", MACN 153880", MACN 153640", MACN 532o, MACN 50443o, MACN 244720", MACN 13299, MACN 29350", MACN 133130", MACN 39194\%, MACN 49160\%, MACN 491480", MACN 49139"', MACN 49134\%, MACN 49149\%, MACN 35241\%, MACN 50504\%, MACN 504940", MACN 504950", MACN 505010", MACN 49159。, MACN 491670", MACN 505020", MACN 50500\%, MACN 50491\%, MACN 50503\%, MACN 156010", MACN 133270", MACN 133310", MACN 14386\%, MACN 157580", MACN 157590", MACN 15769ᄋ, MACN 157680", MACN 157650", MACN 15770。, MACN 15767\%, MACN 157720", MACN 157660", MACN 15771\%, MN 2355․

Lycalopex sechurae - AMNH 465280", AMNH 46527\%, AMNH 46529 ", AMNH 46531\%, AMNH 465330", AMNH 63709 ", AMNH 46532o, AMNH 46530"', AMNH 465250", FMNH 809530", FMNH 809550", FMNH 211290, FMNH 80954o, FMNH 19971。, FMNH 195410, FMNH 19972。, FMNH 80962o, FMNH 80963o, FMNH 80956\%, FMNH 809580", FMNH 80961\%, FMNH 80960", FMNH 80959 ", FMNH 80964o, FMNH 80957\%, FMNH 80968\%, FMNH 809650", FMNH 80969o", FMNH 80966"', FMNH 539130", FMNH 80967o", FMNH 539110", USNM 121172o, USNM 181150。, USNM 121171。, USNM 545110。, USNM 545109o.

Lycalopex vetulus - AMNH 1339280", AMNH 133926o, AMNH 133927o, AMNH 133937o", AMNH 1339290", AMNH 70091。, AMNH 245699o, AMNH 349o, AMNH3910, AMNH 100100@, AMNH 1000910", FMNH 20747o", MCZ NAo, MN 6510, MN 71047o", MN 71093o, MN 4909o", MN 5151\%, MN 71112o, MN 710470", MN 71160。, MN 71122。, MZUSP 305880", MZUSP 30589o, MZUSP 30597o", MZUSP 30598\%, MZUSP 825\%, MZUSP 3047o, MZUSP 30480", MZUSP 10840", MZUSP 3050\%, MZUSP 10160", MZUSP 1018\%, MZUSP 1075o", MZUSP 30460", MZUSP 10120, MZUSP 1011。, MZUSP 3049o, MZUSP 10140", MZUSP 1015 o.

Lycaon pictus - AMNH 831280, AMNH 831290, AMNH 276720, AMNH 1142430", AMNH 1142480", AMNH 114253。, AMNH 114250\%, AMNH 11422470", AMNH 114249 "', AMNH 114252ᄋ, AMNH 114251, AMNH 1142460", AMNH 9038\%, AMNH 820800", AMNH 820820", AMNH 82081\%, AMNH 820850", AMNH 820830", AMNH 820840", AMNH 820860", AMNH 82087\%, AMNH 82088, AMNH 852540, AMNH 818140, AMNH 818130, AMNH 81847o, AMNH 818530, AMNH 81852o, AMNH 101691o, AMNH 1501530, AMNH 1641620", FMNH 351230, FMNH 334780", FMNH 20770。, FMNH 351210, FMNH 35122o, FMNH 1278120", FMNH 20769o, FMNH 127813o, FMNH 24326\%, FMNH 32931\%, FMNH 32930@, FMNH 32932 , FMNH 345880", FMNH 345870", MCZ 132330", MVZ 184049o", MVZ 1242580, MVZ 4842o, MVZ $117806 \circ$.

Nyctereutes procyonoides - AMNH 22792o, AMNH 84342o, AMNH 43142o", 
AMNH 43140o, AMNH 593230", AMNH 601930", AMNH 59322o, AMNH 383260", AMNH 45333\%, AMNH 58370ᄋ, AMNH 844380", AMNH 57340。, AMNH 60123o, AMNH 571130", AMNH 1845720, AMNH 249766o, AMNH 248767o, FMNH 590130", FMNH 336140", FMNH 57169o, FMNH 360020", FMNH 336160, MCZ 222。, MCZ 3143o, MCZ 248530", MCZ 24860", MVZ 119062o", MNHN 2181530", MNHN 240170o, MNHN 254641, MNHN 255532o, MNHN 2561040", MNHN 2561030", MNHN 2555360", MNHN 290623o, MNHN 20944o", MNHN 260687o", MNHN 503941, MNHN 270347o", MNHN 548750", MNHN 522061。, MNHN 290658․

Otocyon megalotis - AMNH 422960\%, AMNH 700300", AMNH 233012o, AMNH 639930", AMNH 1140, AMNH 42960\%, AMNH 83647\%, AMNH 169092。, AMNH 42969o", AMNH 114273o, AMNH 114284o, AMNH 114262o, AMNH 2330130", AMNH 114269o, AMNH 114266o, AMNH 114265o, AMNH 169093。, AMNH 114264o, AMNH 1142820, AMNH 1791420", AMNH 114283o, AMNH 1142710", AMNH 1791430", AMNH 114263o, AMNH 82397o, AMNH 1611530, AMNH 161154o, AMNH 1611510, AMNH 34265o, AMNH 161152o, AMNH 161155o, AMNH 851550", AMNH 85156o, FMNH 14690", FMNH 38189o, FMNH 858820", FMNH 38190。, FMNH 38419 "', FMNH 73043。, FMNH 73041 o", FMNH 1278160", FMNH 1278140", FMNH 127820 "', FMNH 127815o, FMNH 73040o", FMNH 73042o, FMNH 433340", MVZ 1184250", MVZ 184051。, MVZ 993990, MVZ 173742o.

Speothos venaticus - AMNH 98640。, AMNH 1846880, AMNH 1362850", AMNH 374720", AMNH 1753060", AMNH 76805\%, AMNH 76806\%, AMNH 760350", AMNH 985580", AMNH 98560\%, AMNH 1678460, AMNH 98559\%, FMNH 878610", FMNH 1215440", FMNH 60290。, FMNH 1254020", MACN 331540, MACN 165100", MACN 50670", MCZ 410960, MCZ 42086。, MCZ 28056。, MN 25670。, MN 30330", MN 256680", MN 30350", MN 68179o", MPEG 56140", MPEG 17800", MPEG 10420", MPEG 65350", MPEG 65360", MPEG 8794\%, MPEG 1394\%, MPEG 17780", MPEG 111\%, MPEG 5615\%, MPEG 87930", MPEG 26180。, MVZ 1262760", MVZ 1840540", MZUSP 197430, MZUSP 197440", MZUSP 2685o, MZUSP 2684, MNHN 270370。, MNHN 2703680", MNHN 544414, MNHN 179047q, MNHN 521045q, MNHN 307650\%, MNHN 270165q, MNHN 538307。, MNHN 3140480", MNHN 2535040", MNHN 582465。, MNHN 398030œ, MNHN 3958410".

Urocyon cinereoargenteus - MVZ 1154150", MVZ 2316o, MVZ 36810", MVZ 49520。, MVZ 23040", MVZ 110884ㅇ, MVZ 2327。, MVZ 495160", MVZ 70960", MVZ 121587o", MVZ 2325\%, MVZ 70950", MVZ 8828\%, MVZ 190800", MVZ 2330o, MVZ 23280", MVZ 90628, MVZ 90627o", MVZ 948410", MVZ 27868@, MVZ 94840o", MVZ 121588@, MVZ 3250o", MVZ 16249@, MVZ 3959@, MVZ 81326o, MVZ 813250", MVZ 948430", MVZ 37955, MVZ379580", MVZ 2331\%, MVZ 37957ᄋ, MVZ 4536o, MVZ 379530", MVZ 42783, MVZ 379540", MVZ 37628ᄋ, MVZ 4540o", MVZ 27869o", MVZ 70930", MVZ 948420", MVZ 4539o", MVZ 45380", MVZ 32490".

Urocyon littoralis - MVZ 52148o, MVZ 47295o, MVZ113602o, MVZ 1136010", MVZ 38929o", MVZ 521470", MVZ 472960", MVZ 312000", MVZ 31199o", MVZ 31198@, MVZ 31197@, MVZ 7098@, MVZ 7097o", MVZ 109863@, MVZ39925ơ", 
MVZ 1331620", MVZ 133161\%, MVZ 109865\%, MVZ 169864\%, MVZ 109866\%, MVZ 38360\%, MVZ 382590", MVZ 38358\%, MVZ 38357\%, MVZ 38356\%, MVZ 38355\%, MVZ 38352o, MVZ 383510", MVZ 383530", MNHN 156630", MNHN 188081\%, MNHN 188080q, MNHN 45229 , MNHN 1880860", MNHN 188083q, MNHN 188082。, MNHN 1880850", MNHN 1880840", MNHN 188087" , MNHN 471180", MNHN 125480", MNHN 3073940", MNHN 307393@, MNHN 47111ф,

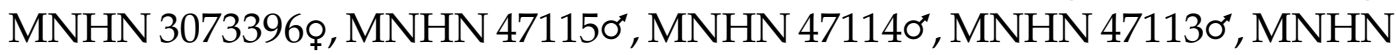
471120", MNHN 920330", MNHN 92029"', MNHN 60674, MNHN 92030@, MNHN 20784\%, MNHN 60673\%.

Vulpes bengalensis - AMNH 545170", AMNH 545170", AMNH 54526\%, FMNH 83083o, FMNH 940950", FMNH 105550。, MNHN 38577o, MNHN 327159o", MNHN 85520, MNHN 257970o.

Vulpes chama - AMNH 148759o, AMNH 81760o, FMNH 85881o, FMNH 384210", FMNH 38422o, MCZ 20077o, MCZ 37021\%, MNHN 2961030", MNHN 4701400", MNHN 384117q, MNHN 368439 $q$, MNHN 296101 $q$, MNHN 296102q, MNHN 368438。, MNHN 429120。, MNHN 368437" , MNHN 253245o", MNHN 2534030", MNHN 469835@, MNHN 4701410", MNHN 4698340", MNHN 469836ᄋ, MNHN 469833o, MNHN 4698310", MNHN 469832o.

Vulpes corsac - ANSP 120940", MCZ 411480.

Vulpes ferrilata - ANSP 175020", ANSP 175060", ANSP 17503@, ANSP '7504\%, FMNH 1422760", MCZ 380880".

Vulpes lagopus - AMNH 345180", AMNH 34517\%, AMNH 345190", AMNH 345200", AMNH 345210", MVZ 1239870", MVZ 116914\%, MVZ 400720", MVZ 40073\%, MVZ 400760", MVZ 40077"', MVZ 400780", MVZ 400790", MVZ 40080\%, MVZ 400810", MVZ 400820", MVZ 400830", MVZ 40084\%, MVZ 40085\%, MVZ 40087\%, MVZ 40074\%, MVZ 400860", MVZ 400880", MVZ 40089o", MVZ 400900", MVZ 40091, MVZ 400920", MVZ 400940", MVZ 40095", MVZ 40096@, MVZ

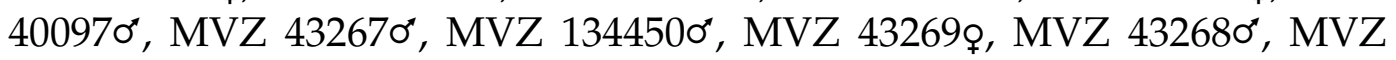
432700", MVZ 43271\%, MVZ 43272\%, MVZ 43273\%, MVZ 43274\%, MVZ 432750", MVZ 43276o, MVZ 43277"', MVZ 432780", MVZ 43279"', MVZ 432800", MVZ 43281\%, MVZ 432880", MVZ 432830", MVZ 467130", MVZ 46715॰, MVZ 467140".

Vulpes macrotis - MVZ 10582q, MVZ 61937q, MVZ 61938\%, MVZ 61939q, MVZ 619400", MVZ 619410", MVZ517260", MVZ 619420", MVZ 845850", MVZ 10584\%, MVZ 105830", MVZ 84586o, MVZ 10585\%, MVZ 70910", MVZ 259030", MVZ 259020", MVZ 114366", MVZ 114367\%, MVZ 2339"", MVZ 70920", MVZ 92559ᄋ, MVZ 798660", MVZ 57330\%, MVZ 74811\%, MVZ 748100", MVZ 70900", MVZ 25904, MVZ 51646ᄋ, MVZ 516440", MVZ 31890", MVZ 31891\%, MVZ 31892ᄋ, MVZ 318950", MVZ318880", MVZ318940", MVZ 318930", MVZ 280630", MVZ 280620", MVZ 28061, MVZ 28060。, MVZ 31886o, MVZ 1223220", MVZ 31889@, MVZ 318870", MVZ 280640", MVZ28059@, MVZ 28058@, MVZ1190470", AMNH 19019\%, AMNH 5890".

Vulpes pallida - AMNH 821980", AMNH 82295\%, AMNH 82296\%, FMNH 1047220", FMNH 91325\%, MNHN 4108170", MNHN 378689q, MNHN 268464q, MNHN 401318", MNHN 378690", MNHN 401317"", MNHN 410918@, MNHN 410536", MNHN 4105330", MNHN 4105260", MNHN 4105320", MNHN 4105240".

Vulpes rueppellii - FMNH 1073330", FMNH 1073340", FMNH 121350", 
FMNH 107264o", FMNH 140125o, FMNH 140134o, FMNH 140139o, FMNH 1401260", FMNH 121351 o", FMNH 1072620", FMNH 1067610", FMNH 1073350", FMNH 1401280", FMNH 1401320", FMNH 140135o, FMNH 140129o", FMNH 1401380", FMNH 140131 o", FMNH 203860", FMNH 107263o, FMNH 140137o", FMNH 1401330", FMNH 140130o, FMNH 140127q, FMNH 107251q, FMNH 1072380", FMNH 107249o", FMNH 1072460", FMNH 106147o", FMNH 107237o, FMNH 107250\%, FMNH 107248\%, FMNH 107239o, FMNH 107247o, FMNH 140144o, FMNH 140140o, FMNH 140145o", FMNH 1401410", FMNH 140142o, FMNH 140143o, FMNH 140150 "', FMNH 107244, FMNH 107245o, FMNH 140149o", MNHN 321959q, MNHN 321963o", MNHN 321961\%, MNHN 328549q, MNHN 154248。, MNHN 321964。, MNHN 3219650", MNHN 321960"', MNHN 401316\%, MNHN 476037o", MNHN 476035\%, MNHN 476036o", MNHN 4013140", MNHN 4013120", MNHN 401315o.

Vulpes velox - AMNH 801270", AMNH 148110", AMNH 14810\%, AMNH 158710", AMNH 15870 o", AMNH 24419o, AMNH 16609。, MVZ 88140。, MNHN 130059\%, MNHN 108319\%, MNHN 108318。, MNHN 67599o, MNHN 108260o", MNHN 136566o, MNHN 1351290", MNHN 1458760", MNHN 145875 , MNHN 1458770", MNHN 145874, MNHN 1463110", MNHN 1463120", MNHN 146317@, MNHN 1463130", MNHN 1462270", MNHN 1462260", MNHN 1463150", MNHN $146318 \%$, MNHN 1463160", MNHN 146321, MNHN 146322。, MNHN 146323。, MNHN 146325\%, MNHN 1463324, MNHN 1347\%, MNHN 1343\%, MNHN 13450", MNHN 5149480", MNHN 289140@.

Vulpes vulpes - MVZ 222287o", MVZ 222275o, MVZ 222274o", MVZ 222270@, MVZ 2222720", MVZ 2222940", MVZ 222293, MVZ 2222950", MVZ 222288ᄋ, MVZ 2222920", MVZ 222276ᄋ, MVZ 2222910", MVZ 222296@, MVZ 2222970", MVZ 222298。, MVZ 2223080", MVZ 222301\%, MVZ 222302o, MVZ 2223090", MVZ 222303o, MVZ 2223040", MVZ 222307\%, MVZ 222312。, MVZ 2223130", MVZ 222315o", MVZ 222310@, MVZ 222321\%, MVZ 222322@, MVZ 222324o, MVZ 222329ᄋ, MVZ 222330@, MVZ 222331。, MVZ 2223320", MVZ 2223340", MVZ 222306"', MVZ 222338。, MVZ 2223420", MVZ 2223430", MVZ 2223440", MVZ 2223450", MVZ 222348, MVZ 222349ᄋ, MVZ 222351@, MVZ 2223520", MVZ 222353, MVZ 222354, MVZ 222355, MVZ 2223560", MVZ 2223580", MVZ 2223590", MVZ 222360o, MVZ 222362o, MVZ 222364, MVZ 222367o.

Vulpes zerda - FMNH 1402000", FMNH 749910", FMNH 1401980", FMNH 79807o", FMNH 140199\%, FMNH 1749900", FMNH 1401960", FMNH 92266o, FMNH 93864o, FMNH 1401970", FMNH 938630", FMNH 936340", FMNH 93635\%, FMNH 927260", FMNH 92723\%, FMNH 927240", FMNH 84570\%, FMNH 89868\%, FMNH 91746\%, FMNH 917430", FMNH 89927o", FMNH 84569o, FMNH 89716 ", FMNH 9272250", FMNH 1072780", FMNH 91748@, FMNH 106605q, FMNH 1072740", FMNH 1072730", FMNH 107279o", FMNH 1402020", FMNH 140204o, FMNH 100109o, FMNH 106645o", FMNH 140203, FMNH 106601。, FMNH 140207o", FMNH 140207o", FMNH 140208ᄋ, FMNH 1066440", FMNH 107275o, FMNH 1072800", FMNH 89940o, FMNH 899340", MVZ $1840640^{\circ \prime}$ 


\section{Ursidae}

Ailuropoda melanoleuca - AMNH 872420, AMNH 147746o, AMNH 1104540, AMNH 110452o, AMNH 110451\%, AMNH 89029o, AMNH 89030\%, ANSP 21719o, ANSP 15050。, FMNH 31128\%, FMNH 36758o, FMNH 39514。, FMNH 31128。, USNM 258425o, USNM 258423o, USNM 2590270", USNM 2588360", USNM 259028०, USNM 2590740", USNM 259029o, USNM 259400。, USNM 2590750", USNM 2594010", USNM 2594020", USNM 2588340", USNM 2588350", USNM 399447o, USNM 259076o.

Helarctos malayanus - AMNH 35484\%, AMNH 116\%, AMNH 296\%, AMNH 35364\%, AMNH 28254\%, AMNH 103987\%, AMNH 607720", ANSP 20235\%, ANSP 19844o, ANSP 31510", ANSP 12933\%, ANSP 134030", MVZ 4816。, MVZ 4162\%, USNM 197254\%, USNM 153839", USNM 1231380", USNM 153835\%, USNM 145580", USNM 145580", USNM 153836o, USNM 153837", USNM 198715\%, USNM 1423440", USNM 1987130", USNM 151866"', USNM 198714\%, USNM 197255\%, USNM 1538380", USNM 358645\%, USNM 2917560".

Melursus ursinus - AMNH 22720 $q$, AMNH 22896", AMNH 35602 $\%$, AMNH 35898@, AMNH 90388?, AMNH 54464\%, AMNH 54467ه", AMNH 54466\%, AMNH 544650", ANSP 2934\%, ANSP 215770", ANSP 42310", ANSP 11827q, ANSP 12946o, ANSP 11973\%, ANSP 12797\%, FMNH 995240", FMNH 995230", FMNH 302530", FMNH 32750\%, FMNH 274420", FMNH 27441\%, USNM 199518\%, USNM 253300\%, USNM 253301․

Tremarctos ornatus - AMNH 2176820", AMNH 70164\%, AMNH 2568120", AMNH 149303\%, AMNH 42473\%, AMNH 677320", AMNH 149302\%, ANSP

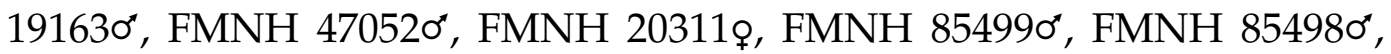
FMNH 412940", FMNH 78678\%, FMNH 884880, FMNH 123369\%, FMNH 134484o, FMNH 142010ф, MACN 178310", MVZ 1241110", USNM 2103230", USNM 210322o, USNM 2714180", USNM 2714210", USNM 271419", USNM 2714200", USNM 2103240", USNM 282620@, USNM 582002q, USNM 194309q, USNM 443519。, USNM 155575o, USNM 1706560, USNM 170657o.

Ursus americanus - MVZ 120840", MVZ18980\%, MVZ 19705\%, MVZ 207460", MVZ 105040", MVZ 133134o, MVZ 47230", MVZ 13764\%, MVZ 192330", MVZ 383380", MVZ 81580"', MVZ 30117"', MVZ 815810", MVZ279930", MVZ 243310", MVZ 162979o, MVZ 1142160", MVZ 162978, MVZ 162984, MVZ 162982, MVZ 162690", MVZ 1629850", MVZ 997410", MVZ 1289210", MVZ 1038980", MVZ 1841500", MVZ 47630", MVZ 310170", MVZ 718050", MVZ 813760, MVZ 162996\%, MVZ 1630080", MVZ 163006@, MVZ 163009@, MVZ 1630010", MVZ 163004\%, MVZ 1630050", MVZ 1630020", MVZ 163003@, MVZ 688430", MVZ 163750", MVZ 301160", MVZ 14712q, MVZ 68854o, MVZ 162998@, MVZ 162997q, MVZ 21399o, MVZ 162994, MVZ 162990\%, MVZ 162988ㅇ.

Ursus arctos - MVZ 2130", MVZ 47280", MVZ 47040", MVZ 437\%, MVZ 216", MVZ 47250", MVZ 217"', MVZ 2140", MVZ 2150", MVZ 47740", MVZ 221, MVZ 2180", MVZ 95220", MVZ 9521o, MVZ 8942o, MVZ 89450", MVZ 43850", MVZ 1841510", MVZ 46990", MVZ 4364, MVZ 324\%, MVZ 3230", MVZ 9523\%, MVZ 4363", MVZ 123990"', MVZ 938820", MVZ 281\%, MVZ 2510", MVZ 43540", MVZ 4386", MVZ 4356。, MVZ 43550", MVZ 43570", MVZ 4692o, MVZ 9700", MVZ 971\%, MVZ 1293920", MVZ 220o, MVZ 4333@, MVZ 
4753o, MVZ 1256100", MVZ 2220", MVZ 47240", MVZ 466280", MVZ 438950", MVZ 1000570", MVZ 466380", MVZ 1000560", MVZ 100058\%, MVZ 466370", MVZ 100060", MVZ 46633\%, MVZ 46642o, MVZ 100049\%, MVZ 46641\%, MVZ 100050@, MVZ 100045@, MVZ 1000510", MVZ 1000480", MVZ 1000460", MVZ 100047\%, MVZ 46631, MVZ 46636\%, MVZ 1000520", MVZ 46625\%, MVZ 88570".

Ursus maritimus - AMNH 156850", AMNH 19260\%, AMNH 215283\%, AMNH

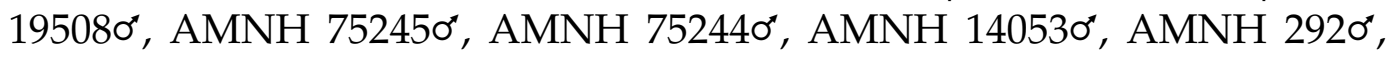
AMNH 34421o, AMNH 2930", AMNH 237920", AMNH 2387890", AMNH 238793\%, AMNH 2387940", AMNH 238799\%, AMNH 2387980, AMNH 238802\%, $\mathrm{AMNH} 238814$ \% , AMNH 238807o, AMNH 238811, AMNH 238810, AMNH

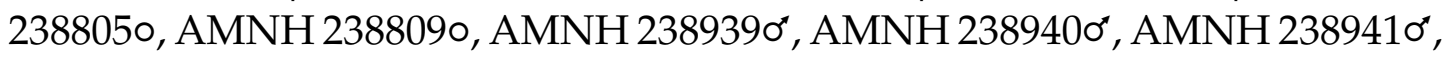

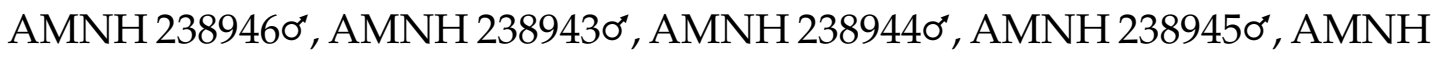

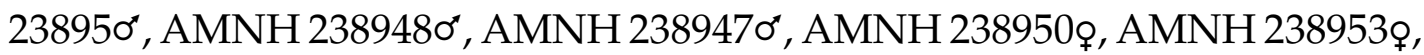
AMNH 238954o, AMNH 2386730", AMNH 2386760", AMNH 2386790", AMNH 2386770", AMNH 238883\%, AMNH 238681\%, MVZ 1268570", MVZ 125564\%, MVZ 119839@, MVZ 124870", MVZ 1190650", MVZ 467120", MVZ 123991, MVZ 128061"', MVZ 46800", USNM 2157140", USNM 2231760", USNM 212590\%, USNM 225604", USNM 227100", USNM 2271050", USNM 227099", USNM 2271040", USNM 2586210", USNM 2283070", USNM 228308", USNM 2292930", USNM 228310 2586220", USNM 336269"', USNM 265099@, USNM 336270"', USNM 1075010", USNM 107500 $q$, USNM 107499 $q$, USNM 275124q, USNM 275117ه", USNM 512112q, USNM 2910190", USNM 2828250", USNM 512113"', USNM 512105q, USNM 512103o, USNM 5121130", USNM 512115o, USNM 512116", USNM 5121260", USNM 5121200", USNM 5121230", USNM 512124o, USNM 512157\%, USNM 512149\%, USNM 512136\%, USNM 512163\%.

Ursus thibetanus - AMNH 354960, AMNH 35489o, AMNH 35016。, AMNH 23086\%, AMNH 1194760", AMNH 1003960", AMNH 80248?, AMNH 70320", AMNH 843890", AMNH 110457o, AMNH 11089o, AMNH 1145440", AMNH 57075o, AMNH 45293o, AMNH 570760, ANSP 12596o, ANSP 126580, ANSP 134920, ANSP 173550", ANSP 15036\%, ANSP 14924o, ANSP 11947o, ANSP 121480, FMNH 25712。, FMNH 31785o, FMNH 31794o, FMNH 993490", FMNH 26924o, FMNH 26923o, FMNH 898960, MVZ 48210, MVZ 4817o, USNM 84092o, USNM 365650", USNM 381950", USNM 22998०, USNM 1878660", USNM 22004ㅇ, USNM 834530, USNM 2586460", USNM 199684\%, USNM 258430。, USNM 2181520", USNM 259099o, USNM 258647\%, USNM 240669\%, USNM 358644o, USNM 240669\%, USNM 221064o, USNM 2585930", USNM 271090。.

\section{Odobenidae}

Odobenus rosmarus - AMNH 1493810", AMNH 2325590", AMNH 213190\%, AMNH 24407\%, AMNH 1210", AMNH 412160", AMNH 1562o, AMNH 779350", AMNH 77986", AMNH 90779\%, AMNH 908770", AMNH 79901\%, AMNH 1799820", AMNH 14230\%, AMNH 19268", AMNH 19267\%, AMNH 19271\%, 
AMNH 192720", AMNH 192730", AMNH 192760", AMNH 19277ø, AMNH 19278\%, AMNH 192810", AMNH 192820", AMNH 19284o, AMNH 19283q, AMNH 19285ᄋ, AMNH 192880", AMNH 19589ᄋ, AMNH 19298\%, AMNH 700990", AMNH 15085\%, AMNH 15086\%, AMNH 15087\%, AMNH 15088\%, AMNH 15089o, AMNH 15091, AMNH 150920", AMNH 156020", AMNH

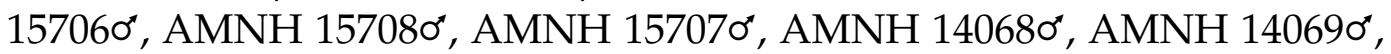
AMNH 14071\%, AMNH 11047\%, AMNH 140460", AMNH 110480", AMNH 110490", AMNH 31646\%, AMNH 73301\%, AMNH 733030", AMNH 733020", AMNH 299030", AMNH 29902@, AMNH 299060", AMNH 29907q, AMNH 299080", FMNH 5508@, FMNH 5505q, FMNH 26889@, FMNH 1408310", FCNyM 15010", FCNyM 15020", MVZ 119066", MVZ 1255590".

\section{Otariidae}

Arctocephalus australis - AMNH 2059180", AMNH 254569", AMNH 2545640", AMNH 2545630", AMNH 254562 ", AMNH 254568ᄋ, AMNH 254565", AMNH 25461\%, AMNH 254567\%, AMNH 2059170", AMNH 2059160", FCNyM 14.IV.48.140", FCNyM 10610", MACN 247320", MACN 218630", MACN 29769", MACN 218620", MCZ 11250", MCZ 1108" MCZ 11260", MVZ1395040", USNH 504900\%, USNH 239140", USNH 366640", USNH 484934o, USNH 504899\%, USNH 504896\%, USNH 501117q, USNH 504897q, USNH 484938q, USNH 50119o", USNH 501120 $q$, USNH 5048950", USNH 504898\%, USNH 4849360, USNH 501118q, USNH 501067q, USNH 484935q, USNH 233310", USNH 3960620", USNH 3969210", USNH 504891\%, USNH 550479", USNH 5504800".

Arctocephalus galapagoensis - AMNH 100319\%, AMNH 1003410", AMNH 100342o, USNH 2597900", USNH 259832o.

Arctocephalus gazella - FCNyM 25.VI.02.80", FCNyM 25.VII.02.12o, FCNyM 25.VI.02.100", FCNyM 25.VI.02.150", FCNyM 25.VI.02.110", FCNyM 25.VI.02.140", FCNyM 25.VII.02.90", FCNyM 25.VI.02.220", FCNyM 25.VI.02.20o, FCNyM 25.VI.02.17o, FCNyM 25.VI.02.180", FCNyM 25.VI.02.190", FCNyM 26.VI.02.160", FCNyM 25.VI.02.240", MACN 236660, MACN 210620", MACN 213510", MACN

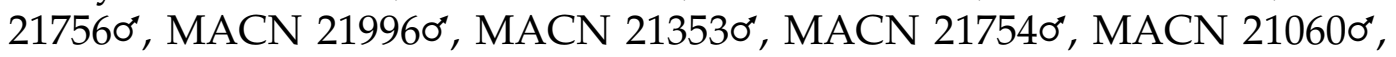
MACN 217600", MACN 21350"', MACN 217590", MACN 213490", MACN

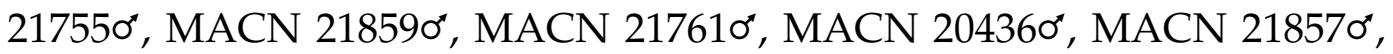
MACN 213520, USNH 3922660", USNH 5500910", USNH 392266", USNH 550090 \%.

Arctocephalus pusillus - AMNH 800830, AMNH 100045o, AMNH 817040, AMNH 817070", AMNH 817050", AMNH 817060", AMNH 817090", AMNH $817080^{\circ}, \mathrm{AMNH} 817110^{\circ}, \mathrm{AMNH} 817100^{\circ}, \mathrm{AMNH} 81714$ \%, AMNH 817130", MCZ 565820", USNH 484928", USNH 396063o.

Arctocephalus townsendi - MVZ 1910030", USNH 83618\%.

Arctocephalus tropicalis - MN 507910", MN 507900", MN $29680 \circ$.

Callorhinus ursinus - AMNH 777960", AMNH 2452990", AMNH 778980", AMNH 71170\%, AMNH 100335\%, AMNH 1003340", FMNH 47266", FMNH 15460", FMNH 15460", FMNH 81505\%, MCZ 1280", MCZ 1088"', MVZ 35090@, MVZ 353550", MVZ 350860", MVZ 175109@, MVZ 153256\%, MVZ 140846\%, 
MVZ 2202550", MVZ 88910@, MVZ 138677@, MVZ 1152230", MVZ 115219@, MVZ 115217\%, MVZ 115228ᄋ, MVZ 115222ᄋ, MVZ 115218ᄋ, MVZ 1152210", MVZ 115220。, MVZ 115225ᄋ, MVZ 1152240", MVZ 115227\%, MVZ 1152260", MVZ 184135o, MVZ 1841360", MVZ 122102, USNH 286130。, USNH 2861350", USNH 286132o, USNH 2861440", USNH 283699o", USNH 286219o", USNH 286204o, USNH 2862140", USNH 286234o", USNH 286230\%, USNH 12740。", USNH 12740'o, USNH 163220", USNH 163210", USNH 38155。, USNH 382250", USNH 47087o", USNH 47084o", USNH 38226\%, USNH 470860", USNH 470880", USNH $470830^{\circ}$.

Eumetopias jubatus - AMNH 1851110", AMNH 384000", AMNH 778010", AMNH 77749o, AMNH 778830", AMNH 1436640", AMNH 1642860", AMNH 622610", AMNH 607970", AMNH 622620", AMNH 622640", AMNH 1813830", AMNH 38401\%, FMNH 299390", FMNH 337700", FMNH 299410", FMNH 29942o, FMNH 299340", FMNH 299320", FMNH 299330", MVZ 1014300", MVZ 91069o", MVZ 191004, MVZ 2085980", MVZ 138679o", MVZ 118620。, MVZ 4897o", MVZ 4117o", MVZ 88876o, MVZ 4967o, MVZ 4964o", MVZ 8827o", MVZ 138680 ', MVZ 1863250", MVZ 186326\%, MVZ 172086\%, USNH 47104, USNH 36310", USNH 47010", USNH 7140"', USNH 6906"', USNH 47020",

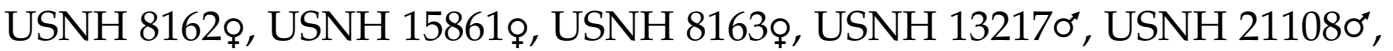

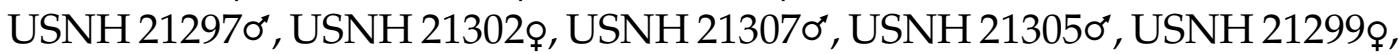
USNH 21309。, USNH 21303o", USNH 21523。, USNH 21304o", USNH 23457\%, USNH 21537\%, USNH 22077o", USNH 220720", USNH 15277o".

Neophoca cinerea - USNH 5047290", USNH 5714630".

Otaria byronia - AMNH 731200", AMNH 731210, AMNH 731190, AMNH 73122ᄋ, AMNH 77800。, AMNH 77799@, AMNH 779100", AMNH 779180", AMNH 77917o", AMNH 2059190", AMNH 779200", FMNH 222470", FMNH 542430", FMNH 208520", FMNH 50789o", FMNH 50790\%, FMNH 50791\%, MACN 412260", MACN 219940", MACN 219840", MACN 13130", MACN 251680",

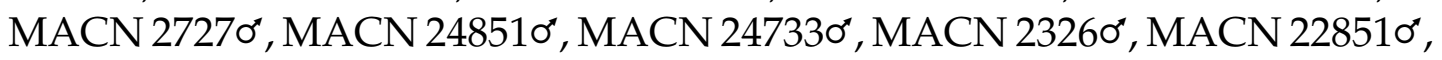
MACN 219950", MACN 223710", MACN 13140", MACN 21738\%, MACN 20578。, MACN 20579o, MACN 1311\%, MACN 21742ᄋ, MACN 22853\%, MACN 20596\%, MN 507870", MN 507880".

Phocarctos hookeri - USNH 344986o, USNH 344983o, USNH 344981 o", USNH 344980 "', USNH 484531 o", USNH 3449820", USNH3449850", USNH $4845260^{\circ}$.

Zalophus californianus - AMNH 180502(m ), AMNH 180459\%, AMNH 1804580", AMNH 1799980", AMNH 1805150", AMNH 193950", AMNH 13907。, AMNH 180461\%, AMNH 180667o", AMNH 180455o, AMNH 180457o, AMNH 180453。, AMNH 18452o, FMNH 104796o, MVZ1751100", MVZ 1863270", MVZ 1863280", MVZ 186320", MVZ 1028180", MVZ 1720650", MVZ 1720680", MVZ 172067ه", MVZ 1720690", MVZ 1720700", MVZ1720710", MVZ 1720730", MVZ 1720760", MVZ 1720770", MVZ 13690", MVZ 13680", MVZ 172066", MVZ 1137200", MVZ 1720850", MVZ 1720830", MVZ1863300", MVZ1392110", MVZ 1392120", MVZ 4895o, MVZ 4103, MVZ 41080", MVZ 113721, MVZ 172097@, MVZ 172099\%, MVZ 135008\%, MVZ 4110\%.

Zalophus wollebaeki - AMNH 639460", AMNH 63947\%, AMNH 2147810", AMNH 99465o, AMNH 214780"', AMNH 2147820", AMNH 994630", AMNH 
994640", AMNH 994610", AMNH 994620", AMNH 736640", FMNH 517600", FMNH 51759\%, FMNH 51748\%, NA 125503\%, USNH 233320", USNH 23280",

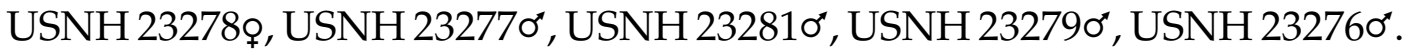

\section{Phocidae}

Cystophora cristata - AMNH 184660\%, AMNH 950", AMNH 150417o, AMNH 970", AMNH 101990", AMNH 108\%, AMNH 96\%, AMNH 100135\%, AMNH 1846590", AMNH 2325650", AMNH 2121850", USNM 210430", USNM 1888450", USNM 6576\%, USNM 382330", USNH 188852q, USNH 188850\%, USNH 188848\%, USNH 1888460", USNH 6577\%, USNH 1888650", USNH 1888610", USNH 1888620",

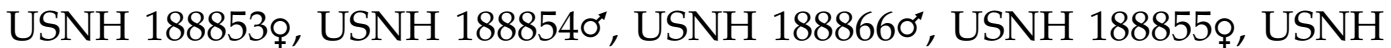
188867\%, USNH 188868\%, USNH 1888640", USNH 1888630", USNH 188882o, USNH 188877q, USNH 188889 $q$, USNH 188869\%, USNH 188881q, USNH 188871q, USNH 188890\%, USNH 188891, USNH 188895\%, USNH 188894q, USNH 188898\%, USNH 188899\%, USNH 188900", USNH 188896\%, USNH 1889030", USNH 1889040", USNH 188897\%, USNH 188893\%, USNH $1889050^{\circ}$.

Erignathus barbatus - AMNH 229430, AMNH 752540, AMNH 752540, AMNH 75249o, AMNH 22942o, AMNH 193470", AMNH 980, AMNH 280970", AMNH 99o, AMNH 19313\%, AMNH 733310, AMNH 280", AMNH 101360, AMNH 181660", AMNH 1439010, AMNH 18165o, AMNH 10202ᄋ, AMNH 101350, AMNH 18167o, AMNH 157740", FMNH 815030, FCNyM 1055o, MVZ 124013\%, MVZ 1240190", MVZ 125584\%, MVZ 128914\%, MVZ 1289130, MVZ 1255820", MVZ 124021\%, MVZ 1255810", MVZ 124015, MVZ 1255770", MVZ 125576\%, MVZ 125575, MVZ 125569\%, MVZ 125578\%, MVZ 1240160", MVZ 125573, MVZ 1281240", MVZ 1289160", MVZ 125570", MVZ 124020@.

Halichoerus grypus - AMNH 1030", AMNH 1255910", AMNH 1255930, AMNH 100191\%, AMNH 173535\%, AMNH 69489"', AMNH 694870", AMNH 694880", AMNH 69490", FMNH 815060", MVZ 1400050", MVZ 186579@, USNH 19837\%, USNH 38237q, USNH 352910", USNH 446405\%, USNH 446406\%, USNH 4747o, USNH 5044810".

Histriophoca fasciata - AMNH 1302460, AMNH 1302450", MCZ 522390", MCZ 522400", MVZ 513870", MVZ 513850", USNH 16484o, USNH 504959o, USNH 504960。, USNH 3117710, USNH 399449o, USNH 571367o.

Hydrurga leptonyx - AMNH 362000", AMNH 48157o, AMNH 77914o, AMNH 173537o, ANSP 24880, FCNyM 1059o, FCNyM 6910, FCNyM 14.IV.48.110, FCNyM 26.IV.00.14o, MN 53662o, MVZ 127753०, USNH 270315o, USNH 269533\%, USNH 157580, USNH 275205\%, USNH 2703260", USNH 275298\%, USNH 5503580, USNH 550360", USNH 277255\%, USNH 3969310, USNH 550359o, USNH 5716760.

Leptonychotes weddellii - AMNH 85517o, AMNH 85512o, AMNH 884460", AMNH 2121920, AMNH 88447\%, AMNH 88450\%, AMNH 88453\%, AMNH 88454\%, AMNH 88454\%, AMNH 884520", AMNH 884690", AMNH 88473\%, AMNH 884890", AMNH 884820", AMNH 884850", AMNH 884920", AMNH 884880", AMNH 88590\%, AMNH 884990", AMNH 885010", AMNH 88507\%, AMNH 88508\%, AMNH 88506\%, AMNH 88505\%, AMNH 88504\%, AMNH 
88510, AMNH 88513, AMNH 88511, AMNH 885140, AMNH 885150, AMNH 88520。, AMNH 885210, AMNH 885280, AMNH 885410, AMNH 88547o, AMNH 885510, AMNH 885480, AMNH 88557o, AMNH 885560, AMNH 212171\%, AMNH 30574o, FCNyM 31.xII.02.24o, FCNyM 14.IV.48.120", MACN 492520, MACN 22610"', MACN 206280, MACN 228540", MACN 1327o, MACN 1919o, MACN 20628o, MCZ 51874, MCZ 51710。, MCZ 51731o", MCZ 51712, MCZ 51711․

Lobodon carcinophaga - AMNH 885460, AMNH 884450", AMNH 884490", AMNH 884840", AMNH 884870", AMNH 88474ㅇ, AMNH 884900", AMNH 884930", AMNH 884940", AMNH 884960", AMNH 884980", AMNH 85510。, AMNH 855130", AMNH 885290, AMNH 88530。, AMNH 885340, AMNH 885360, AMNH 885330, AMNH 88539o, AMNH 885380, AMNH 88540。, AMNH 88537o, AMNH 88549o, AMNH 885520, AMNH 885430, FMNH 43885o, FCNyM 30.XII.02.110, FCNyM 22.III.99.10。, FCNyM 4740, MACN 1920o, MCZ 52287。, MCZ 518510, MVZ 127754o, MVZ 127752。, MVZ127757o, MVZ 127751\%, USNH 269722。, USNH 550077\%, USNH 270324, USNH 2752040", USNH 550078ᄋ, USNH 270385\%, USNH 2703250", USNH 550080@, USNH $5500830^{\prime \prime}$.

Mirounga angustirostris - AMNH 77930\%, AMNH 326760", AMNH 326780", AMNH 32677o, AMNH 326790", FMNH 412510", FMNH 514400", FMNH 41253, MVZ 162301, MVZ 1622980", MVZ 162299o", MVZ 1623020", MVZ 1623000", USNH 20927\%, USNH 21887\%, USNH 38234, USNH 21890。, USNH 2190580", USNH 2608670", USNH 255975o, USNH 2653530", FMNH 41249o.

Mirounga leonina - AMNH 779230", AMNH 779280", AMNH 481510", AMNH 481520", AMNH 48156\%, AMNH 48155\%, AMNH 48154, AMNH 48160\%, AMNH 48159o, AMNH 48161" $0^{\circ}, \mathrm{AMNH} 481620^{\circ}, \mathrm{AMNH} 481630^{\circ}, \mathrm{AMNH}$ 481530", AMNH 48166, AMNH 77911, AMNH 77912。, AMNH 779160", AMNH 779190", AMNH 702400", AMNH 349040", FMNH 108860", FCNyM 947o", FCNyM 26.IV.00.130", FCNyM 15040", MACN 22614。, MACN 22612。, MACN 22613。, MACN 24910", MACN 206080", MACN 13260", MN 50786\%, USNH 15336 $q$, USNH 239141\%, USNH 504927\%, USNH 550379\%, USNH 484893o".

Monachus monachus - AMNH 73608\%, USNH 2190590.

Neomonachus schauinslandi - USNH 1812500", USNH 243840 0", USNH 2438380", USNH 243842o, USNH 243839o, USNH 3957860, USNH 334573o, USNH 243849o, USNH 2438440", USNH 395787o, USNH 334577o, USNH 395997o, USNH 3957610, USNH 204680, USNH 5048920", USNH 3959950, USNH 396000。, USNH 504893o, USNH 504926o.

Neomonachus tropicalis - AMNH 19600。, AMNH 156660", AMNH 777410", AMNH 15896\%, AMNH 10421 "', ANSP 4963o, USNH 100354o", USNH 100355\%, USNH 2254430", USNH 1003680", USNH 100364\%, USNH 100360\%, USNH 100356\%, USNH 100357\%, USNH 100361。, USNH 100365\%, USNH 100369o, USNH 1003630", USNH 100358 "', USNH 1003580", USNH 100370。, USNH 100366\%, USNH 100359\%, USNH 100362, USNH 100367\%, USNH 102524\%, USNH 102525\%, USNH 102528\%, USNH 100372\%, USNH 100371\%, USNH 100373\%, USNH 102532(Monachus tropicalis), USNH 102530@, USNH 1025230", USNH 102531\%, USNH 102527\%, USNH 102526\%, USNH 102529o", USNH 
102533\%, USNH 102534q, USNH 102535\%, USNH 102536q, USNH 102537q.

Ommatophoca rossii - MACN 48259o, MCZ 518520, MCZ 52305o, USNH 270316\%, USNH 2752060", USNH 270321\%, USNH 339989o, USNH $302975 \circ$.

Pagophilus groenlandicus - AMNH 150419(x), AMNH 1864350, AMNH 1800160, AMNH 101380", AMNH 73327o, AMNH 101400", AMNH 10139", AMNH 101410, AMNH 101420", AMNH 101480", AMNH 101440", AMNH 10180\%, AMNH 101460", AMNH 193070", AMNH 10150", AMNH 10149", AMNH 101430", AMNH 10145。, AMNH 10152ᄋ, AMNH 101470", AMNH 10151\%, AMNH 101550, AMNH 101780", AMNH 10157q, AMNH 10158\%, AMNH 10156o, AMNH 101530, AMNH 10154\%, AMNH 101790", FMNH 9866", FMNH 30369o, MCZ 8985o, MCZ 89830", MCZ 89840", MCZ 8959\%, MCZ B8988@, MCZ B8990。, MCZ B8987@, MCZ 89910", MCZ 89860", MCZ 93740, MCZ 9006"', MCZ 89920", MCZ 89890", MCZ 77340", MCZ 77360", MCZ 77240", MCZ 60604\%, MCZ 60716\%, MCZ 640930", MCZ 640920".

Pusa caspica - USNH 341650", USNH 341616", USNH 341617o.

Pusa hispida - AMNH 752560, AMNH 28099 9 , AMNH 28098@, AMNH 90801, AMNH 752530, AMNH 229410, AMNH 90800。, AMNH 73330。, AMNH 187o, AMNH 10214。, AMNH 104o, AMNH 105o, AMNH 107o, AMNH 10212。, AMNH 10217o, AMNH 10210。, AMNH 10215o, AMNH 102110, AMNH 102130, AMNH 193050", AMNH 193080", FMNH 30367q, FMNH 67404o, FMNH 303660, FMNH 30361\%, MCZ 7747\%, MCZ 6297\%, MCZ 62960", MCZ 6295o, MCZ 77420, MCZ 77430, MCZ 77410, MCZ 6969o, MCZ 376210, MCZ 7745०, MCZ 77460, MCZ 21809o, MCZ 470660, MCZ 29804。, MCZ 47447o, MCZ 85120, MCZ 60957\%, MVZ 123996\%, MVZ 125568\%, MVZ 124000@, MVZ 123999@, MVZ 1239980", MVZ 1240030", MVZ 124002@, MVZ 1240040", MVZ 124001, MVZ 125612ᄋ, MVZ 123997\%, MVZ 125611\%, MVZ 134146o.

Phoca largha - AMNH 18169\%, AMNH 15817o, AMNH 198430, AMNH 18169\%, AMNH 212250。, MCZ 6970。.

Pusa sibirica - AMNH 206594o, AMNH 185195@, AMNH 185595@, MCZ 12654o, MVZ 140629\%, USNH 175690\%, USNH 550028。, USNH 550034o, USNH 550029 o.

Phoca vitulina - MVZ 172131\%, MVZ 1721320", MVZ 1721290", MVZ 172130\%, MVZ 172119\%, MVZ 191005\%, MVZ 172121\%, MVZ 1751050", MVZ 172120。", MVZ 1960470", MVZ 172125\%, MVZ 1721090", MVZ 172107@, MVZ 172117\%, MVZ 1721060", MVZ 1721130", MVZ 1721050", MVZ 196035\%, MVZ 196048\%, MVZ 1960430", MVZ 196046o, MVZ 1960450", MVZ 1721040", MVZ 208580\%, MVZ 1408490", MVZ 4757\%, MVZ 208593\%, MVZ 172115@, MVZ 208588०, MVZ 2085790", MVZ 2085780", MVZ 1720820", MVZ 172110", MVZ 175103\%, MVZ 1721120", MVZ 2085720", MVZ 175107@, MVZ 175102@, MVZ 1532620", MVZ 1532600", MVZ 175106\%, MVZ 1751010", MVZ 175108, MVZ 175104\%, MVZ 208569 , MVZ 208575\%, MVZ 1147780", MVZ 208584\%, MVZ 208585\%, MVZ 2085590", MVZ 2085870", MVZ 1721110", MCZ 11455@. 


\section{Mephitidae}

Conepatus chinga - FMNH 293010", FMNH 29293o, FMNH 292940", FMNH 29291\%, FMNH 29292o, FMNH 292800", FMNH 292820", FMNH 293000", FMNH 29286o, FMNH 29298。, FMNH 292890", FMNH 292880", FMNH 1060020, FMNH 29287q, FMNH 29297o, FMNH 27673q, FMNH 29285@, FMNH 292990", FCNyM 20.XII.00.6o, FCNyM 2007o, FCNyM 5.V.99.5o, FCNyM 2.Vi.60.13o, FCNyM 5.V.99.7o, FCNyM 11.IX.98.80, FCNyM 8.IX.98.3o, FCNyM 5.V.99.4o, MN 1501。, MN 3130。, MN 31280, MN 15000", MN 133850", MN 593350, MN 48730", MPEG 222310, MPEG 22189 ', MPEG 222320, MPEG 22233o, MPEG 221900", MVZ398750, MZUSP 1009o", MZUSP 35380, MZUSP 229o, MZUSP 2310。, MZUSP 1010。, MZUSP 2309。, MZUSP 2280", MZUSP 30680", MZUSP

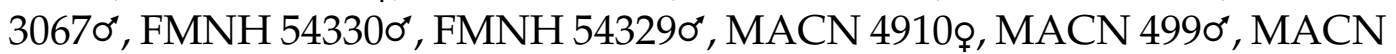
363220", MACN 303930", MACN 32251\%, MACN 13714\%, MACN 4915q, MACN 504210", MACN 363240", MACN 30102ᄋ, MACN 367280", MACN 34330"', USNM 1727920, USNM 172794。, USNM 172793o, FCNyM 8.V.59.4o, FCNyM 8.V.59.6o, FCNyM 7.X.46.10", FCNyM 1582o, FCNyM 6580, FCNyM 1727o, FCNyM 3.X.94.10, FCNyM 330。, FCNyM 1277o, FCNyM 10.II.99.10, FMNH 497200, FMNH 49732o, FMNH 49733o, FMNH 497340", FMNH 497230", FMNH 106007o, FMNH 52486o, FMNH 49724o, FMNH 497250", FMNH 497260", FMNH 49727o, FMNH 49728@, FMNH 49729\%, FMNH 49731@, MVZ1147750", MVZ 117776o, MVZ 114940ᄋ, MVZ 135823。, MVZ 114941。, FMNH 243550", FMNH 21356o.

Conepatus humboldtii - FCNyM 1.xii.00.5o, FCNyM 1.XII.00.4o, MACN 164750", MACN 49420", MACN 2049o, MACN 2874o, MACN 28720", MACN 13297" ", MACN 15549 ", MACN 1988。, MACN 363320", MACN 10510", MACN 14084o", MACN 15573。, MVZ 1622880, MVZ 159444。, MVZ 1722410, MZUSP 2313。, MZUSP 2580, MZUSP 10880, MZUSP 257o", MZUSP 2315o, FCNyM 533o, FCNyM 7020, FCNyM 325o, FCNyM 2026o, FCNyM 2027o, FCNyM 2025o, FCNyM 20280.

Conepatus leuconotus - AMNH 1284700", AMNH 129709o, AMNH 1284710", AMNH 1297100", AMNH 128472o, AMNH 128997\%, AMNH 1284730", AMNH 292810", MVZ 982950", MVZ 1321650", MVZ 132164, MVZ 1321610", MVZ 98298\%, MVZ 1321700", MVZ 132169ᄋ, MVZ 1321660", MVZ 1321600", MVZ 132159ᄋ, MVZ 1321680", MVZ 1321610", MVZ 31331。, MVZ 117020\%, MVZ 1061160", MVZ 803360", MVZ 52002o, MVZ 85320\%, MVZ 85318@, MVZ 109609o", MVZ 109608\%, MVZ 1096060", MVZ 62707o", MVZ 1211060", MVZ 109607。, MVZ 76291, MVZ 743350", MVZ 1218240", MVZ 324910", MVZ 324930", MVZ 324940", MVZ 324950", MVZ 32497o", MVZ $324960^{\circ}$.

Conepatus semistriatus - AMNH 172190\%, FMNH 13852\%, FMNH 44336\%, FMNH 1251130", FMNH 22202o, FMNH 187700", FMNH 380610", FMNH 58560\%, FMNH 19680\%, FMNH 199760", MACN 3162o, MVZ 135824, MVZ 84332ᄋ, MZUSP 8453\%, MZUSP 26490", USNM 657630", USNM 2814520", USNM 65762ᄋ, USNM 281464o", USNM 281457o", USNM 281461\%, USNM 281462。, USNM 281459\%, USNM 281455\%, USNM 281460o", USNM 281465\%, USNM 281463o, USNM 281458\%, USNM 2814560", USNM 4432910", USNM 442414, USNM 372745\%, USNM 443295\%, USNM 443294, USNM 443293\%, 
USNM 3882440", USNM 443289, USNM 443285\%, USNM $4435760^{\circ}$.

Mephitis macroura - FMNH 86830", FMNH 8682o, FMNH 54320", FMNH 139960", FMNH 15043o, FMNH 13997\%, MVZ 100116\%, MVZ 1001150", MVZ 1001140", MVZ 911670", MVZ 1001220", MVZ 1001210", MVZ 1001190", MVZ 1001180", MVZ 100117 "', MVZ 1001250", MVZ 100124ㅇ, MVZ 1001230", MVZ 85323, MVZ 85322o, MVZ 85321, MVZ 1284960", MVZ 95020", MVZ 50256\%, MVZ 853260", MVZ 853250", MVZ 853240", MVZ 132138。, MVZ 132139。, MVZ 1321360", MVZ 1321370", MVZ 1321350", MVZ 1321340", MVZ 982940", MVZ 98292o, MVZ 98293, MVZ 132143, MVZ 1321420", MVZ 132140。, MVZ 1321440", MVZ 1321450", MVZ 1321510", MVZ 1321460", MVZ 1321480", MVZ 132150․

Mephitis mephitis - MVZ 59815q, MVZ 598110", MVZ 102294o, MVZ 227171, MVZ 1841100", MVZ 1490080", MVZ 1251840", MVZ 349950", MVZ 34994, MVZ 59817。, MVZ 598160", MVZ 59814ㅇ, MVZ 32329o", MVZ 62850, MVZ 90336。, MVZ 59818。, MVZ 34996o, MVZ 146400", MVZ 28066。, MVZ 936130", MVZ 936112ᄋ, MVZ 23693@, MVZ 163329o", MVZ 11742@, MVZ 211350", MVZ 211340", MVZ 236690", MVZ 21568@, MVZ 101327\%, MVZ 24417o, MVZ 23694o", MVZ 19732o, MVZ 19742o, MVZ 19741o", MVZ 19740o", MVZ 19739@, MVZ 197380", MVZ 19736。, MVZ 108073, MVZ 21570o", MVZ 21569o, MVZ 3763o, MVZ 38854o, MVZ 881700", MVZ 88169, MVZ 149772。, MVZ 95469o, MVZ 90449ㅇ.

Mydaus javanensis - AMNH 1066360", AMNH 31811\%, AMNH 1027010", AMNH 102702q, ANSP 14084o, ANSP 14083o", FMNH 68730o", FMNH 68729o, MNHN 1562870", MNHN 348940", MNHN 1214980", MNHN 121497。.

Mydaus marchei - FMNH 62882o, FMNH 628770", FMNH 11580", FMNH 628780", MNHN 144958@, MNHN 478276ᄋ, MNHN 4782780", MNHN 478277o".

Spilogale angustifrons - FMNH 741200", FMNH 741190", FMNH 741180", FMNH 74117。, FMNH 733380", FMNH 485120", USNM 511520", USNM 881540", USNM 204370", USNM 508220", USNM 3346720", USNM 790170", USNM 555850", USNM 1201010", USNM 50824요, USNM 349120", USNM 508230", USNM 81716\%, USNM 508210", USNM 81717ð", USNM 334674o, USNM 337938\%, USNM 3378260", USNM 3346710", USNM 3379370", USNM 3399720", USNM 337640"', USNM 3346730", USNM celeriso, USNM 3346750", USNM 337641\%, USNM 361358, USNM 5654560", USNM 5654540", USNM 5654550", USNM 779160", USNM 735200", USNM 735190", USNM 735210", USNM 735240", USNM 73527\%, USNM 735280", USNM 75321․

Spilogale gracilis - MVZ 34993o, MVZ 47169o", MVZ 40760", MVZ 4077ᄋ, MVZ 219160", MVZ 21915o, MVZ 16579o", MVZ 149009o, MVZ 28731\%, MVZ 73900", MVZ 16264, MVZ 773240", MVZ 58873@, MVZ 588720", MVZ 24826ᄋ, MVZ 248250", MVZ 38298@, MVZ 124139o, MVZ 146410", MVZ 599660", MVZ 599650", MVZ 1073920", MVZ 1073910", MVZ 44279@, MVZ 107395\%, MVZ 107394, MVZ 1073930", MVZ 21564, MVZ 236230", MVZ 23622o, MVZ 4279o, MVZ 42780", MVZ 236950", MVZ 23670o, MVZ 89560", MVZ 1227430", MVZ 197270", MVZ 1154130", MVZ 36120", MVZ 101507o", MVZ 90447ه", MVZ 21567。, MVZ 215660", MVZ 38878\%, MVZ 19728@, MVZ 21565@, MVZ 22119o, MVZ 2013220". 
Spilogale putorius - FMNH 77350", FMNH 77340", FMNH 21920。, FMNH 6875o, FMNH 68760", FMNH 68770", FMNH 68780", FMNH 10960。, FMNH 10959 ", FMNH 513730", FMNH 49145o, FMNH 1998520", FMNH 199842o, FMNH 1998370", FMNH 199838o, FMNH 1998390", FMNH 199840 o", FMNH 10961。, FMNH 1998460, FMNH 199847o, FMNH 199845o, FMNH 1998430, FMNH 1998440, FMNH 1998480", FMNH 199850 ", FMNH 1998490", FMNH 1998410", FMNH 5438\%, USNM 703080", USNM 171840", USNM 703050", USNM 703060", USNM 70307o", USNM 64019@, USNM 70309o", USNM 231609o", USNM 243510。, USNM 703040", USNM 640210", USNM 263620\%, USNM $171850^{\prime \prime}$.

Spilogale pygmaea - AMNH 1751830", MVZ 1555810", MVZ 1555810", MVZ 155580\%, MVZ 1555790", USNM 523998ㅇ.

\section{Ailuridae}

Ailurus fulgens - AMNH 1466820", AMNH 353870", AMNH 1194740, AMNH 354330, AMNH 146778o, AMNH 1694960, AMNH 1196760, AMNH 354950, AMNH 110455。, AMNH 117408०, ANSP 191850", ANSP 21583\%, ANSP 20128\%, ANSP 13493o, ANSP 12160。, FMNH 36749o", FMNH 367530", FMNH 367500", FMNH 367520, FMNH 367510", FMNH367540, FMNH 36755。, FMNH36756。, FMNH 36757o, FMNH 114384o, FMNH 60762o, FMNH 57324o, FMNH 573360, FMNH 60452\%, FMNH 60497o", FMNH 60046\%, FMNH 448750", FMNH 65803\%, FMNH 1049500", MCZ 3579o, MCZ 52237\%, MVZ 136208\%, MVZ 13215\%, MVZ 1237010", MVZ 1194830", USNM 259379@, USNM 256098\%, USNM 258350。, USNM 2521460", USNM 252091\%, USNM 258051\%, USNM 3057710", USNM 396950\%, USNM 252087\%.

\section{Procyonidae}

Bassaricyon alleni - AMNH 98709o, AMNH 70532。, AMNH 1422230, AMNH 67706\%, FMNH 104935\%, FMNH 86908\%, FMNH 86909\%, FMNH 62079o, FMNH 41501\%, FMNH 65787\%, FMNH 659880", FMNH 658050", FMNH 65789 ", FMNH 425020", MACN 5081 "', MACN 50820", MACN 3168。, MCZ 379230", MCZ 37922ᄋ, MCZ 37920@, MVZ 155220@, MVZ 1536460", MVZ 155219o", USNM 281484o", USNM 281483॰, USNM 281482。, USNM 194315॰, USNM 544415o, USNM 443279o, USNM 443718。, USNM 2814850", USNM 443717。.

Bassaricyon gabbii - AMNH 140334。, AMNH 30748\%, USNM 5169450", USNM 516946\%, USNM 316230\%, USNM 338859\%, USNM 3376320", USNM 324294ㅇ, ANSP 11160", MCZ 385060.

Bassaricyon medius - AMNH 37797q, FMNH 86852q, FMNH 69578q, FMNH 90049\%, FMNH 90051\%, FMNH 29180o", USNM 397350o", USNM 598997q, USNM 363342\%, USNM 324296\%, USNM 179158\%, USNM 1711380", USNM 3070360", USNM 3633440", USNM 1790530", USNM 3633430", USNM 3242950", USNM 3057510", USNM 335768 "', USNM 3057530", USNM 3388940", USNM 305750 o", USNM 3357710", USNM 3357700", USNM 338348\%, USNM 307037q, USNM 310666\%, USNM 284903, USNM 284934q, USNM 284933q, USNM 


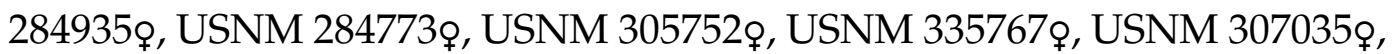
USNM 305748\%, USNM 335769\%, USNM 305749\%, MVZ 1241120".

Bassaricyon neblina - FMNH 707230", FMNH 707250", FMNH 90052@, FMNH 707240", FMNH 70721\%, FMNH 89220\%, FMNH 707260", FMNH 858180".

Bassariscus astutus - MVZ 38870@, MVZ215610", MVZ388710", MVZ 999690", MVZ 9531\%, MVZ 221080", MVZ 21560\%, MVZ 21559\%, MVZ 215580", MVZ 21557\%, MVZ 596950", MVZ 596950", MVZ 192085\%, MVZ 38877\%, MVZ 106180\%, MVZ 343060", MVZ 343050", MVZ 34304, MVZ 59698\%, MVZ 59697\%, MVZ 184143ㅇ, MVZ 229631ㅇ, MVZ 128890", MVZ 12888\%, MVZ 128870", MVZ

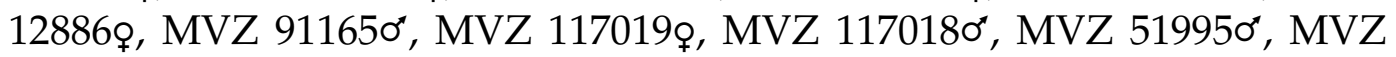
51994\%, MVZ 519930", MVZ 519910", MVZ 51990\%, MVZ 94907\%, MVZ 520000", MVZ 51999", MVZ 51998@, MVZ 51997\%, MVZ 519960", NA 803290", NA 803280", NA 743340", NA 74333\%, NA 803310", NA 80330".

Bassariscus sumichrasti - AMNH 100890", AMNH 135927\%, AMNH 137987\%, AMNH 1353330", AMNH 137990", AMNH 1355840", AMNH 1770740", AMNH $1489760^{\circ}, \mathrm{AMNH} 1488040^{\circ}, \mathrm{AMNH} 1488030^{\circ}, \mathrm{AMNH} 145160 \%, \mathrm{AMNH} 232477 q$, AMNH 254529 $q$, AMNH 2148940", AMNH 178706", AMNH 175090 68524\%, AMNH 172199\%, MVZ 98275\%, MVZ 982780", MVZ 982770", MVZ 1320730", MVZ 98276@, MVZ 982820", MVZ 1841440", MVZ 982810", MVZ 98280ф, MNHN 181256 MNHN 181257" , MNHN 159730", MNHN 133185o, MNHN 292254o, MNHN 340740\%, MNHN 340738\%, MNHN 340737\%, MNHN 70820, MNHN 340735\%, MNHN 8077", MNHN 8978@, MNHN 13850", MNHN 1812550", MNHN 138490", MNHN 3407360", MNHN 3407390".

Nasua narica - AMNH 141977" , AMNH 140620", AMNH 135970 1418550", AMNH 1418540", AMNH 139317" , AMNH 126182o, AMNH 126183q, AMNH 173530", AMNH 145938 ", AMNH 1232780", AMNH 123276o, AMNH 68525o, AMNH 165973\%, AMNH 145936\%, AMNH 145151\%, AMNH 149144\%, AMNH 145153o, AMNH 145157\%, AMNH 1459460", AMNH 145650", AMNH 145947\%, AMNH 143968", AMNH 1459320", AMNH 145933", AMNH 145651\%, AMNH 1456520", AMNH 145942o, AMNH 145960\%, AMNH 145152, , AMNH 145943, AMNH 1721920", AMNH 17261\%, AMNH 172560", AMNH 284340", AMNH 28958\%, AMNH 29439\%, AMNH 284330", MVZ 132107\%, MVZ 238400", MVZ 98260\%, MVZ 98259\%, MVZ 132112ㅇ, MVZ 122109, MVZ 132114\%, MVZ 132116o, MVZ 132115\%, MVZ 982650".

Nasua nasua - MPEG 1207", MPEG 1531\%, MPEG 870", MPEG 4268\%,

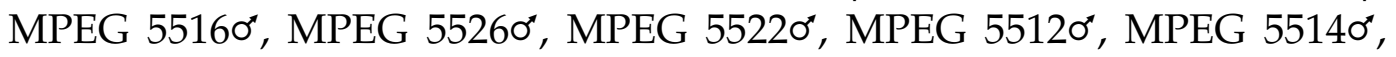
MPEG 55550", MPEG 5536ᄋ, MPEG 55350", MPEG 55340", MPEG 55330", MPEG 55540", MPEG 5530 $q$, MPEG 55450", MPEG 5552ᄋ, MPEG 5553\%, MPEG 5549@, MZUSP 71530", MZUSP 7154\%, MZUSP 71240", MZUSP 19776\%, MZUSP 55370", MZUSP 5555\%, MZUSP 71210", MZUSP 5544\%, MZUSP 5245\%, MZUSP 197910", MZUSP 71560", MZUSP 5556。, MZUSP 5243@, MZUSP 19779q, MZUSP 197830", MZUSP 19781, MZUSP 254560", MZUSP 197800", MZUSP 19784우, MZUSP 196750", MZUSP 5538", MZUSP 8020", MZUSP 49830", MZUSP 5250o, MZUSP 5543@, MZUSP 197750", MZUSP 197690", MZUSP 55470", MZUSP

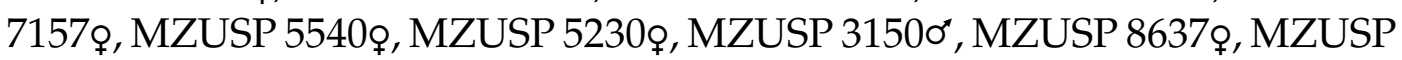


5228, MZUSP 21333॰, MZUSP 31480", MZUSP 25760", MZUSP 3149o", MZUSP 28910", MZUSP 28090", MZUSP 79770", MZUSP 7379॰, MZUSP 75220", MZUSP 7800@, MZUSP 2650@, MZUSP 8301, MZUSP 83020", MZUSP 63110", MZUSP 6312o, MZUSP 6310o", MZUSP 28543o, MZUSP 28542o, MZUSP 285410", MZUSP 63090".

Nasuella meridensis - MZUSP 25280", USNM 143658․

Nasuella olivacea - AMNH 181493\%, AMNH 18489o, AMNH 323580", AMNH 330490", AMNH 670840", FMNH 868500", FMNH 892360", FMNH 70747q, FMNH 707460", FMNH 707480", FMNH 707440", FMNH 70749o, FMNH 707450", FMNH 707420", FMNH 707410", FMNH 707430", USNM 240034o.

Potos flavus - MACN 50850", MACN 50840", MACN 50830", MACN 32146\%, MN 4866o, MN 4867\%, MN 4874ㅇ, MN 48760", MN 4877\%, MN 48810, MN 4880o, MN 5162o, MN 5689\%, MN 5714의, MN 5722o, MN 5716\%, MN 5721。, MN 32409o", MN 30980", MN 32406。, MN 10972。, MN 10965。, MN 109680", MN 10969o", MN 10966", MN 10970\&, MN 109710", MN 32419o", MN 32321\%, MN 113960", MN 10992o, MN 32423\%, MN 5639o", MN 32415\%, MN 555000 o", MN 49030", MN 4902\%, MN 4851\%, MPEG 4342o, MPEG 70830", MPEG 4347\%, MPEG 7084o, MPEG 4348\%, MPEG 6529o, MPEG 4334\%, MPEG 4339\%, MPEG 43450", MPEG 43330", MPEG 1974。, MPEG 4341\%, MPEG 43400", MPEG 4336\%, MPEG 4335ᄋ, MPEG 4337 ${ }^{\circ}$, MPEG 228910, MPEG 38540。, MPEG 228540", MPEG 122640", MPEG 197150", MPEG 226050", MZUSP 5563o, MZUSP 7381\%, MZUSP 8951\%, MZUSP 4055o, MZUSP 7382o, MZUSP 21330。, MZUSP 7519o", MZUSP 7520@, MZUSP 55340", MZUSP 8645o".

Procyon cancrivorus - AMNH 628690", AMNH 61601\%, AMNH 214734\%, AMNH 94247\%, AMNH 2151290", MACN 13816\%, MACN 50690", MACN 32254\%, MACN 16190\%, MACN 5070q, MN 3087\%, MN 4897q, MN 11203q, MN 23887q, MN 7256\%, MN 28802\%, MN 25657q, MN 7612o, MN 238850", MN 7625\%, MPEG 4210\%, MPEG 6821\%, MPEG 721\%, MPEG 42080", MZUSP 197940", MZUSP 11800", MZUSP 2982。, MZUSP 2809 ', MZUSP 28250", MZUSP 23370", MZUSP 23060", MZUSP 14370", MZUSP 223630, MZUSP 223640", MZUSP 21627o", MZUSP 22418०, MZUSP 223620", MZUSP 22365०, MZUSP 223660", MZUSP 21628\%, MZUSP 16730", MZUSP 28240", MZUSP 19795\%, MZUSP 19852o.

Procyon lotor - MVZ 24602o, MVZ 16545o", MVZ 102281, MVZ 18468\%, MVZ 90703o", MVZ 1092550", MVZ 107708\%, MVZ 102286o, MVZ 18472\%, MVZ 1212280", MVZ 11739o", MVZ 21125\%, MVZ 11737o", MVZ 1389900", MVZ 16266, MVZ 16267\%, MVZ 7082o, MVZ 7084, MVZ 166660", MVZ 34159ᄋ, MVZ 34160ᄋ, MVZ 28000 o", MVZ 1018100", MVZ 1018130", MVZ 101808@, MVZ 101807o", MVZ 101809@, MVZ 128839o", MVZ 102287\%, MVZ 129830", MVZ 101325\%, MVZ 1013260", MVZ 101626\%, MVZ 101812o, MVZ 1018110", MVZ 335920", MVZ33593@, MVZ 335940", MVZ 97902@, MVZ 979030", MVZ 979050", MVZ 992940", MVZ 97904, MVZ 108056\%, MVZ 1389910", MVZ 32450@, MVZ 324510", MVZ 1418210", MVZ 347530", MVZ 7080@, MVZ 3240@, MVZ 33617o", MVZ 3611, MVZ 89900".

Procyon pygmaeus - MCZ 55723o, MNHN 108512@, MNHN 108509o", MNHN 108510ф, MNHN 108508․ 


\section{Mustelidae}

Aonyx cinerea - FMNH 38009q, FMNH 88612q, FMNH 121229q, FMNH 88611q, FMNH 74281o, FMNH 1253840", FMNH 62868ᄋ, FMNH 1357390", FMNH 628690", FMNH 129494, MVZ 170987\%, MVZ 184090o, USNM 151879o, USNM 114465\%, USNM 1553240", USNM 198054, USNM 19183o, USNM 1228400", USNM 144434, USNM 481273, USNM 4782830", USNM 535212, USNM 3149790".

Aonyx congicus - MVZ 19210o", USNM 175520ㅇ.

Arctonyx albogularis - AMNH 32258\%, AMNH 573730", AMNH 843910", AMNH 414750", AMNH 113710 "', AMNH 850250", AMNH 571180", AMNH 1174120", AMNH 110460。, AMNH 1104640", AMNH 452940", AMNH 110461。, ANSP 15037\%, FMNH 39506\%, FMNH 39373o, USNM 259015\%.

Arctonyx collaris - AMNH 873940", AMNH 372210", ANSP 151780", ANSP

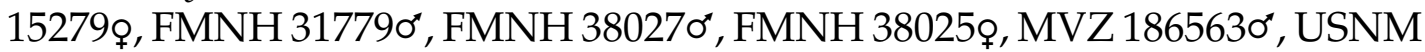
2778520", USNM 835170", USNM 835160", USNM $2588600^{\circ}$.

Arctonyx hoevenii - ANSP 20230o, ANSP 20232o.

Eira barbara - MN 68625\%, MN 299760", MN 6089o, MN 60850", MN 60880", MN 5619o", MN 63452。, MN 5649o", MN 109900", MN 300030", MN 74385。, MN 5512o, MN 7611\%, MN 29977q, MN 683570", MN 68358\%, MN 3102q, MN 3107\%, MN 750960", MN 49040", MN 4906\%, MN 4907\%, MN 51630", MPEG 3310", MPEG 1340", MPEG 15230", MPEG 56250", MPEG 56290", MPEG 5627\%, MPEG 5632q, MPEG 100140", MPEG 10013q, MZUSP 594, MZUSP 5188\%, MZUSP 5189o", MZUSP 926\%, MZUSP 5192q, MZUSP 5140\%, MZUSP 51910", MZUSP 3672。, MZUSP 10145\%, MZUSP 10143, MZUSP 5186\%, MZUSP 51870", MZUSP 52750", MZUSP 5195\%, MZUSP 19806\%, MZUSP 19845\%, MZUSP 19803\%, MZUSP 198040", MZUSP 19799o, MZUSP 19809\%, MZUSP 19802q, MZUSP 229010", MZUSP 198100", MZUSP 198070", MZUSP 19800@, MZUSP 7029o", MZUSP 3375o", MZUSP 4244o, MZUSP 3917\%, MZUSP 4243。, MZUSP 4242。, MZUSP 2726。, MZUSP 2237o", MZUSP 2727o", MZUSP 5933॰, MZUSP 27280", MZUSP 65840", MZUSP 6811, MZUSP 29720", MZUSP 29750", MZUSP 1162。, MZUSP 29760", MZUSP 19817\%, MZUSP 1161, MZUSP 18070", MZUSP 28480", MZUSP 29750", MZUSP 29740", MZUSP 2924, MZUSP 4880", MZUSP 7699, MZUSP 37600", MZUSP 31840", MZUSP 24680", MZUSP 2469o.

Enhydra lutris - MVZ 6956o, MVZ163330o", MVZ 116213, MVZ 114550。, MVZ 116611。, MVZ 140630o", MVZ 1840920", MVZ 154700@, MVZ 1358310", MVZ 1840930", MVZ 342360", MVZ 1133960", MVZ 1198240", MVZ 848120", MVZ 184096"', MVZ 186320"', MVZ 1231920", MVZ 123194, MVZ 1231960", MVZ 1231980", MVZ 123197o", MVZ 123199o, MNHN 1464380", MNHN 146439o", MNHN 146440٪, MNHN 146441@, MNHN 36266 , MNHN 2854130", MNHN 263315 $\circ^{\circ}$, MNHN 2854250", MNHN 2717480", MNHN 286368。, MNHN 2863820", MNHN 2863740", MNHN 286379 "', MNHN 2854810", MNHN 2854330", MNHN 2888130", MNHN 288799, MNHN 288815, MNHN 288818, MNHN 286398, MNHN 288798@, MNHN 288810 "', MNHN 288811q, MNHN 2888120".

Galictis cuja - AMNH 2359920", AMNH 332810", AMNH 205832o, AMNH 2125440", AMNH 38983o, FCNyM 20200", FCNyM 15.V.97.42o, FCNyM 8.V.59.60", FCNyM 23.X.98.3o, FCNyM 6.III.36.250", FCNyM 20340", MACN 232910", 
MACN 13939ᄋ, MACN 236040", MACN 165200", MACN 16254, MACN 139630", MACN 130750", MACN 30960", MACN 30950", MPEG 22230。, MPEG 221880", MPEG 22229o, MVZ 1147740", MVZ 851640", MZUSP 198210", MZUSP 66500", MZUSP 64670", MZUSP 84540", MZUSP 978o, MZUSP 96330", MZUSP 30660", MZUSP 231\%, MZUSP 2320", MZUSP 12470", USNM mo", USNM 2715730", USNM 1727960", FCNyM 10140", FCNyM 7040", FCNyM 12610", FCNyM 3880", FCNyM 3. V.99.40", FCNyM 6710", FCNyM 6740", FCNyM $12620^{\circ}$, FCNyM 1028。, FCNyM 17060", FCNyM 17050".

Galictis vittata - AMNH 62870", AMNH 35257\%, AMNH 985680", AMNH 985710", AMNH 98572o, AMNH 985690", AMNH 776950", AMNH 76630\%, AMNH 173910 0", AMNH 76856。, MACN 5091\%, MPEG 85220", MPEG 4221\%, MPEG 4220\%, MPEG 56510", MPEG 42220", MPEG 42230", MPEG 226030", MPEG 1139 "', MPEG 6520\%, MPEG 65240", MPEG 226040", MPEG 88610", MVZ 1840980", MVZ 157992o, MVZ 155227\%, MVZ 155226\%, USNM 292156\%, USNM 443283o", USNM 443720ф, USNM 395050॰", USNM 281481q, USNM 460074, USNM 361041\%, USNM 362246o.

Gulo gulo - AMNH 34506\%, AMNH 34500\%, AMNH 374320", AMNH 374320", AMNH 19842o, AMNH 229330", AMNH 194850", AMNH 37433\%, AMNH 229320", AMNH 137270\%, AMNH 37431\%, AMNH 182935\%, AMNH 1695010", AMNH 165766o, AMNH 34448\%, AMNH 182934\%, AMNH 109\%, AMNH 182630", MVZ32807q, MVZ 16373@, MVZ 33475@, MVZ 43460", MVZ 221210", MVZ 22120@, MVZ 1198430", MVZ 4682o, MVZ 4683@, MVZ 1198420", MVZ 4218。, MVZ 4217o, MVZ 1281190", MVZ 44167。, MVZ219810", MVZ1238220", MVZ 123994, MVZ 101129, MVZ 184100, MVZ 184099o", MVZ 1222360", MVZ 122238, MVZ 122239o", MVZ 4799, MVZ 33267\%, MVZ 43633, MVZ 43632o", MVZ 122237o", MVZ 43625\%, MVZ34396o, MVZ436310", MVZ119841o", MVZ 30049o".

Hydrictis maculicollis - AMNH 51829@, AMNH 51825@, AMNH 518280", AMNH 518270", AMNH 2396130", AMNH 898070", AMNH 898080", AMNH 1199550, AMNH 824020", USNM 2203960, USNM 429136o.

Ictonyx libyca - MVZ 34190o", USNM 379079o, USNM 410550\%, USNM 454406 "', USNM 4544050", USNM 4021540", USNM 454407ه", USNM 4021560", USNM 402155o, USNM 4760280", USNM 4105420", USNM 4105530", USNM 410554, USNM 410541\%, USNM 410549\%, USNM 410547q, USNM 4105460", USNM 410544, USNM 4105520", USNM 350097\%, USNM 410543o", USNM 3500960", USNM 3171110", USNM 317113。, USNM 4021580", USNM 410548\%, USNM 410540 "', USNM 4760280", USNM 4021570", USNM 342062o, USNM 3420650", USNM 3420640", USNM 3420630", USNM 342061, USNM 317110 o", USNM 317109\%, USNM 350095\%, USNM 317108․

Ictonyx striatus - AMNH 806660", AMNH 806640", AMNH 116288\%, AMNH 1162840", AMNH 1162850", AMNH 1162870", AMNH 116286", AMNH 116282ᄋ, AMNH 1162830", AMNH 116280@, AMNH 116295\%, AMNH 1162980", AMNH 116293\%, AMNH 116290"', AMNH 116297\%, AMNH 1162960", AMNH 1162910", AMNH 116301\%, AMNH 1163040", AMNH 116300"', AMNH 116308\%, AMNH 116311\%, AMNH 116307o", AMNH 1163180", AMNH 116309\%, AMNH 116320"', AMNH 168959 ", AMNH 1689610", AMNH 168958。, AMNH 1689620", AMNH 
1689650", AMNH 1689640", AMNH 168966"', AMNH 1689680", AMNH 1689670", AMNH 168975o, AMNH 1689740", AMNH 168972ᄋ, AMNH 168969", AMNH 168973@, MVZ 1184280", MVZ 1178140", MVZ 1184360", MVZ 1184380", MVZ 1184290", MVZ 117815\%, MVZ 118432o.

Lontra canadensis - FMNH 196096o, FMNH 171158\%, FMNH 171149q, FMNH 1711550", FMNH 167045॰, FMNH 1766210", FMNH 1766210", MVZ 46661\%, MVZ 515770", MVZ 19098"“", MVZ 191520", MVZ 33621, MVZ 38872o, MVZ 36530。, MVZ 23665", MVZ 24768\%, MVZ 253350", MVZ 247790", MVZ

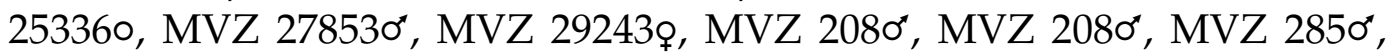
MVZ 44150", MVZ 21242o, MVZ 21243०, MVZ 19087\%, MVZ 12475\%, MVZ 44000", MVZ 4401\%, MVZ 986\%, MVZ 43380", MVZ 190880", MVZ 25554\%, MVZ 614510", MVZ 191530, MVZ 126530, MVZ 38894o, MVZ 19154"', MVZ 353560, MVZ 333180, MVZ 445710", MVZ 389890", MVZ 389900", MVZ 38988\%.

Lontra felina - ANSP 24460, FMNH 24226(f), FMNH 242230", FMNH 49884。, FMNH 412420", MVZ 1416320", MVZ 1416310", MVZ 1418680, MVZ 1195560, USNM 257680, USNM A24785o, USNM 512791․

Lontra longicaudis - AMNH 78512\%, AMNH 4765o, AMNH 670990", AMNH 98589", AMNH 188309", AMNH 2051760", AMNH 133949o, AMNH 205902o, AMNH 133950\%, AMNH 207729\%, AMNH 142247\%, AMNH 14633。, AMNH 1422480, AMNH 23507o, AMNH 23494o, AMNH 298410", AMNH 38121\%, AMNH 33191\%, AMNH 29840", AMNH 66780", AMNH 639580, AMNH 96286\%, AMNH 800920", AMNH 41940。, AMNH 74458\%, AMNH 64114\%, AMNH 214498०, AMNH 718610", AMNH 230840。, AMNH 71860。, FMNH 695820", FMNH 62265o, FMNH 165540, FMNH 935360", FMNH 68320@, FMNH 93535\%, FMNH 68321o, FMNH 980790", FMNH 784610, MN 222550", MN 25628。, MN 50800॰, MN 3031०, MN 30200", MN 30002。", MN 25680。, MVZ 153652@, MVZ 1709660", MVZ 116823。, MZUSP 51710", MZUSP 5172o, MZUSP 1080\%, MZUSP 103660".

Lontra provocax - FMNH 24222o, FMNH 242240".

Lutra lutra - AMNH 2065920", AMNH 32257\%, AMNH 44788\%, AMNH 1294", AMNH 36598\%, AMNH 240918, AMNH 890", ANSP 20234 20010", ANSP 113950", ANSP 52640", ANSP 6844\%, FMNH 814910", FMNH 85860", FMNH 39181q, FMNH 1043930", FMNH 758630", FMNH 75858q, FMNH 75859q, FMNH 758610", FMNH 75860\%, FMNH 995225q, FMNH 99385", FMNH 993830", FMNH 993840", FMNH 97843\%, MVZ 34264o, USNM 259466 @, USNM 199613@, USNM 3585730", USNM 188617\%, USNM A012920", USNM 188616 $\%$, USNM 1541570", USNM A21120\%, USNM 1886150", USNM 874ㅇ, USNM 3277350".

Lutra sumatrana - FMNH 660140", USNM 142337\%, USNM 3090150", USNM 309014\%, USNM 142336o.

Lutrogale perspicillata - AMNH 99610。, AMNH 1631860, AMNH 2129780, FMNH 63799(f).

Lyncodon patagonicus - FCNyM 1255o, FCNyM 27.III.96.10, FCNyM 1256o, FCNyM 6.III.36.320, MACN 312140", MVZ 163429o.

Martes americana - MVZ 33627\%, MVZ 115553\%, MVZ 248220", MVZ 336260", MVZ 248230", MVZ328080", MVZ 382940", MVZ 382930", MVZ 382920", MVZ 
230410", MVZ 23040 o", MVZ 13770ᄋ, MVZ 13769o", MVZ 137680", MVZ 13767o", MVZ 34163o", MVZ 34162ᄋ, MVZ 22113o", MVZ 22110。, MVZ 22109o", MVZ 365740", MVZ 137730", MVZ 137720", MVZ 13771。, MVZ 696340", MVZ 2167700", MVZ 230430", MVZ 23042o, MVZ 46665o, MVZ 46664, MVZ 627760", MVZ 62775o", MVZ 62774o", MVZ 37495\%, MVZ37494, MVZ37493。, MVZ95042o", MVZ 2086653, MVZ 97313@, MVZ 97310@, MVZ 627770", MVZ 328010", MVZ 97312o.

Martes flavigula - AMNH 101633@, AMNH 80155\%, AMNH 1066200", AMNH 80110\%, AMNH 1028810", AMNH 1066210", AMNH 106622o, AMNH 171164q, AMNH 27615。, AMNH 431480", AMNH 43147ㅇ, AMNH 110474o, AMNH 110472ᄋ, AMNH 570460", AMNH 110473o, AMNH 383310", AMNH 559040", AMNH 59317\%, AMNH 85044, AMNH 84445\%, AMNH 113029ᄋ, AMNH 206591\%, AMNH 87391 o", AMNH 171167o", AMNH 171165o", AMNH 1635810", AMNH 163580@, AMNH 1635850", AMNH 163587\%, AMNH 1635820", AMNH 1635840", AMNH 1635860", AMNH 163583o, AMNH 107135\%, AMNH 103999q, AMNH 106062。, AMNH 106061\%, AMNH 117629\%, AMNH 117619\%, AMNH 1176210", AMNH 84894, ANSP 152790", ANSP 19266", ANSP 152780".

Martes foina - AMNH 163433。, AMNH 1634340", AMNH 163435\%, AMNH 163436\%, AMNH 69516\%, AMNH 69517o", AMNH 6289o, AMNH 701820", AMNH 70236o, FMNH 358270", MVZ772930", MVZ 772940", USNM 173300 ', USNM 173299"', USNM 173298"', USNM 173297\&, USNM 1732960", USNM 1732950", USNM 1733060", USNM 1733050", USNM 173304, USNM 173303。, USNM 173302。, USNM 173301\%, USNM 173309o", USNM 1733080", USNM 173307\%, USNM 1733100", USNM 173313, USNM 173315\%, USNM 1740750", USNM 174078ᄋ, USNM 1984810", USNM 198485\%, USNM 1733110", USNM 1740760", USNM 174077o", USNM 198483@, USNM 198482@, USNM 198484o", USNM 1733140".

Martes martes - AMNH 69527\%, AMNH 36633。, AMNH 183359o, FMNH 84721 “", USNM 1291 o", USNM 12910", USNM 1881010", USNM 1964。, USNM 188100요.

Martes melampus - AMNH 1845750", AMNH 184574o, MVZ 114424o", USNM 138320", USNM 138330", USNM 1156840.

Martes pennanti - AMNH 1215570", AMNH 125580", MVZ 165960", MVZ 213960", MVZ 247400", MVZ 23686o, MVZ 236680", MVZ 1967160", MVZ 43621, MVZ 54935o", MVZ 54934o", MVZ 44543o, MVZ 44532o, MVZ 43624o", MVZ 43623o, MVZ 43615\%, MVZ 43619\%, MVZ 436180", MVZ 43617o, MVZ 44534o, MVZ 44533o", MVZ 445310", MVZ31129o, MVZ31093o, MVZ 29809o", MVZ 297910", MVZ 298110", MVZ 1862820", MVZ 238840", MVZ 238830", MVZ 1325320", MVZ 97899\%, MVZ 20955\%, MVZ 185230@, MVZ 31133@, MVZ 311320", MVZ 29813, MVZ 29812o, MVZ 1862810", MVZ 186283․

Martes zibellina - AMNH 977990", AMNH 978000", MVZ 49430", USNM 113948, USNM 113991, USNM 113990@, USNM 219860", USNM 113980", USNM 113969o, USNM 113960"', USNM 208840", USNM 113993, USNM 113970\%, USNM 113962o, USNM 49483o", USNM 113949\%, USNM 49484o", USNM 113951\%, USNM 113950\%, USNM 1139710", USNM 1139810", USNM 113992 “", USNM 113972o, USNM 1139850", USNM 11739740", USNM 1139820", 
USNM 1139630", USNM 834490", USNM 1139520", USNM 113954o, USNM 834510", USNM 113965\%, USNM 83450\%, USNM 113953\%, USNM 113975q, USNM 113983@, USNM 113956", USNM 1139440", USNM 113966", USNM 113977\%, USNM 113976o, USNM 113986, USNM 113984ㅇ.

Meles anakuma - AMNH 18698\%, USNM 239340".

Meles leucurus - AMNH 85048\%, AMNH 57117\%, AMNH 843560, ANSP 16691\%, ANSP 150320, FMNH 36735(m ), FMNH 57164\%, FMNH 57195\%, MVZ 3987740, USNM 199041(m ), USNM 242566o.

Meles meles - AMNH 695130, AMNH 695120, AMNH 695030, AMNH 173524o, AMNH 70602o, AMNH 1295o, AMNH 993460, AMNH 70603o, AMNH 977940", ANSP 2449o, MVZ 1841060", MVZ 342650", MVZ 21980。, MVZ 129663\%, MVZ 1296620", USNM 188600", USNM 38434。, USNM 534227\%, USNM 319225o, USNM 257677o, USNM 1541540", USNM 2576760, USNM 1886010", ANSP 4047o, ANSP 525o, ANSP 2450。, ANSP 3310。.

Meles canescens - AMNH 695110, AMNH 88700\%, AMNH 88698 $0^{\circ}$, FMNH 978370", FMNH 984350, FMNH 984340, FMNH 474180", USNM 171964o, USNM 327733\%, USNM 3277320", ANSP 17516\%.

Mellivora capensis - AMNH 342620, AMNH 342630, AMNH 69499o, AMNH 818310, AMNH 81232ᄋ, AMNH 51951, AMNH 51952o, AMNH 1690850", AMNH 1196220", AMNH 83450。, ANSP 121580", ANSP 3814。, FMNH 35694(FMNH), FMNH 85510 ", FMNH 297940", FMNH 43298०, MVZ 184107o, MNHN 537650。, MNHN 1757510, MNHN 2961070", MNHN 164700。, MNHN 2833410.

Melogale everetti - FMNH 108979\%, FMNH 108980@, FMNH 49254\%, USNM

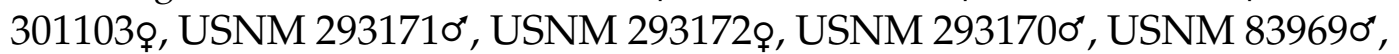
USNM 2928930", USNM 2928910", USNM 292887q, USNM 292888\%, USNM 292890", USNM 292892@, USNM 2928940", USNM 2928890".

Melogale moschata - AMNH 43168 ", AMNH 44709\%, AMNH 85028\%, AMNH 43167\%, AMNH 60191\%, AMNH 453360", AMNH 850260", AMNH 57033\%, AMNH 58271\%, AMNH 56930", AMNH 582720", AMNH 59980\%, AMNH 60031\%, AMNH 599780", AMNH 600870", AMNH 600590", AMNH 60034q, AMNH 60058\%, AMNH 60032\%, AMNH 60035\%, AMNH 38329\%, AMNH 85031\%, AMNH 1851230", AMNH 1851220", AMNH 1851210", AMNH 184976\%, AMNH 185389", AMNH 185390\%, AMNH 1845440", AMNH 184975\%, AMNH 1849770", AMNH 1849740", MVZ 186566", MVZ 186565\%, MVZ 1748400", MVZ 174839ᄋ, MVZ 184108@, MNHN 3306960", MNHN 330698@, MNHN 294294\%, MNHN 3307060", MNHN 3307020", MNHN 330699@, MNHN 330700q, MNHN 2942950", MNHN 3307010", MNHN 3306950", MNHN 3585720".

Melogale orientalis - AMNH 102086o, AMNH 102074ㅇ, AMNH 1020760", AMNH 102695\%, AMNH 102075q, AMNH 102089", AMNH 102088 , MVZ 186567\%, MNHN 1215010, MNHN 522010"', MNHN 522009"', MNHN 522011q, MNHN 5220120", AMNH 31806\%.

Melogale personata - FMNH 30888", FMNH 37996\%, FMNH 37994\%, FMNH 37997\%, FMNH 37995\%, FMNH 39129\%, FMNH 308870", USNM 2578310", USNM 2971710", USNM 253410。, USNM 5052420", USNM 2580150", USNM 3553290", USNM 2580140", USNM 356605 ", USNM 356828", USNM 3572940", USNM 358076\%, USNM 356929\%, USNM 261614\%, USNM 3566040", USNM 
356597\%, USNM 3565980", USNM 356599o, USNM 356600o", USNM 3566010", USNM 5431020", USNM 3572930", USNM 3577430", USNM 3569310", USNM 3576250", USNM 3577390", USNM 3576260", USNM 3577410", USNM 3577400", USNM 358077\%, USNM 3569300", USNM 3577420", USNM 3580710", USNM 358078q, USNM 358105o", USNM 358073», USNM 358074, USNM 358075q, USNM 358072o.

Mustela africana - AMNH 61813\%, MPEG 65150", MPEG 6528\%, MPEG

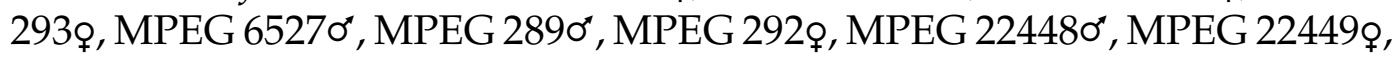
MPEG 224430", MPEG 22446ᄋ, MPEG 65260", MPEG 22450 0", USNM $2551190^{\circ}$.

Mustela altaica - AMNH 1176050", AMNH 117604o, FMNH 49923o, FMNH 447700", FMNH 44348\%, FMNH 44769o", FMNH 46039\%, USNM 621100", USNM 1984760", USNM 1984750", USNM 198474, USNM 84059\%, USNM 198473@, USNM 84058\%, USNM 176038\%, USNM 1760370", USNM 1760360", USNM 176035\%, USNM 176034\%, USNM 1760330", USNM 3544220", USNM 3544210", USNM 2705340", USNM 270608\%, USNM 270609․

Mustela erminea - MVZ 438110", MVZ 43810o", MVZ 41064o", MVZ41063, MVZ 41061o", MVZ 40177o", MVZ 40175o, MVZ 534380", MVZ 53783o, MVZ 86689o", MVZ 86680", MVZ 86687o", MVZ32577o, MVZ 325760", MVZ325750", MVZ 325730", MVZ 43816ᄋ, MVZ 43815ᄋ, MVZ 438130", MVZ 438120", MVZ 53419o", MVZ 534130", MVZ 534110", MVZ 534100", MVZ 534160", MVZ 53417o", MVZ 534140", MVZ 106860", MVZ 106830", MVZ 434030", MVZ 434020", MVZ 434010", MVZ 434000", MVZ 433990", MVZ 433980", MVZ 43397o", MVZ 433940", MVZ 433930", MVZ 433920", MVZ 43391 o", MVZ 433840", MVZ 433850", MVZ

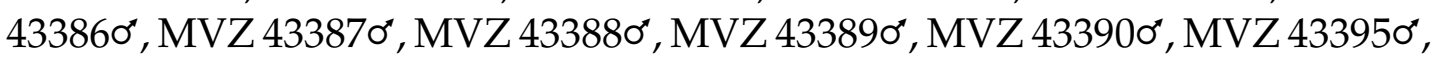
MVZ $433960^{\circ}$.

Mustela eversmanni - AMNH 601020", AMNH 45605\%, AMNH 84312o, AMNH 85382ᄋ, AMNH 45606。, AMNH 573380", FMNH 134578\%, USNM 1726310", USNM 1551610", USNM 1551620", USNM 188449o", USNM 1754410", USNM 175439q, USNM 22191\%, USNM 383650", USNM 188448\%, USNM 269134, USNM 2597920", USNM 221920", MVZ 412060.

Mustela felipei - FMNH 897450", FMNH 709990".

Mustela frenata - MVZ 324210", MVZ 410380", MVZ 519730", MVZ973460", MVZ 14700@, MVZ 1145080", MVZ 51666o", MVZ 120868@, MVZ 85158@, MVZ 798210", MVZ 66010o", MVZ 100040@, MVZ 1073570", MVZ 108067@, MVZ 3761, MVZ 91059\%, MVZ 119049@, MVZ 958210", MVZ 95822。, MVZ 95823o, MVZ 958240", MVZ 958250", MVZ 467230", MVZ 119050o, MVZ1190510", MVZ 1190520", MVZ 328200", MVZ 1145600", MVZ 1292560", MVZ 1120200", MVZ 23909o, MVZ 54957o", MVZ 119807\%, MVZ 40302o", MVZ 90474, MVZ 19723o, MVZ 197220", MVZ197210", MVZ 197200", MVZ 19719o", MVZ 197180", MVZ 699990", MVZ 699950".

Mustela itatsi - AMNH 378500", USNM 1408950", USNM 140894o, USNM 1408930", USNM 1408920", USNM 1408900", USNM 209420", USNM 1408960",

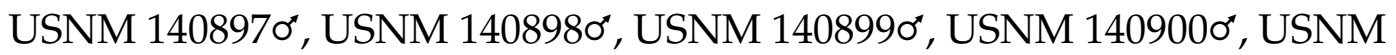
1409010", USNM 140902。, USNM 140903o", USNM 140904o", USNM 1409050", USNM 1409060", USNM 1409080", USNM 140909o", USNM 1409110", USNM 1409120", USNM 1409130", USNM 1409140", MVZ 1134250". 
Mustela kathiah - AMNH 43172o, AMNH 1148830", AMNH 1635790", AMNH 56940。, AMNH 47879 ", AMNH 445750", AMNH 601950", AMNH 873930", AMNH 45502\%, AMNH 150090 ', AMNH 47880 ', FMNH 39121\%, FMNH 393630", FMNH 75808o, FMNH 848080", FMNH 84809 ", FMNH 758090", FMNH 32504o, FMNH 325030", FMNH 325020", FMNH391220", USNM 254587。, USNM 254411\%, USNM 2581800".

Mustela lutreola - AMNH 206590。, ANSP 504o, ANSP 495o, USNM $38466 \circ$.

Mustela nigripes - AMNH 25460", AMNH 228940", AMNH 228200", AMNH 419940", AMNH 12030", AMNH 1403970", AMNH 425670", AMNH 1216100", AMNH 705900", AMNH 350410", AMNH 400780", FMNH 25623o, FMNH 167200 o", FMNH 256210", FMNH 256220", MVZ 778400", MVZ 55212。, MVZ 2201470", MVZ 660190", MVZ 702090", MVZ 184119@, MVZ 78134o", USNM 2341180", USNM 2282330", USNM 247073, USNM 32771, USNM 223110", USNM 224270", USNM 300660", USNM 300650", USNM 30064o, USNM 1107720", USNM 188450"', USNM 1884530", USNM 839940", USNM 83993॰, USNM 839920", USNM 1884540", USNM 188452。, USNM 1884510", USNM 188456\%, USNM 1884550", USNM 188457\%, USNM 1884580", USNM 2244500", USNM 234971\%, USNM 2349730", USNM 232400o“, USNM 234970@.

Mustela nivalis - MVZ 1188750", MVZ 1187130", MVZ 1187150", MVZ 140472o, MVZ 14471, MVZ 134457ð", MVZ 1344520", MVZ 134456。, MVZ 129405, MVZ 128907o", MVZ 1212020", MVZ 432880", MVZ 1212010", MVZ 40059ᄋ, MVZ 432890", MVZ 125600o", MVZ 128911, MVZ 1344580", MVZ 1068630", MVZ 121141\%, MVZ 150827\%, MVZ 184120\%, MVZ 129406\%, MVZ 118720ه", MVZ 1187170", MVZ 128708, MVZ 118719ᄋ, MVZ 118721\%, MVZ 1188730", MVZ 118718。, MVZ 1188740", MVZ 1719520", MVZ 1235870", MVZ 1293830", MVZ 171951, MVZ 41213, MVZ 412120", MVZ 783080", MVZ 171954, MVZ 171953o, MVZ 410310", MVZ 538010", MVZ 41030o.

Mustela nudipes - ANSP 66740, ANSP 202330", FMNH 886070, FMNH 882900", USNM 1518780", USNM 3011020, USNM 2673860", USNM 4893850", USNM 4893860".

Mustela putorius - AMNH 777300", AMNH 695200", AMNH 695190", AMNH 36631 0", AMNH 1634370", AMNH 695210", AMNH 77727o, AMNH 695180", AMNH 350930", AMNH 180190", AMNH 243106o, AMNH 200850", AMNH 3528\%, AMNH 181985\%, AMNH 235238\%, AMNH 2352240", AMNH 235239\%, AMNH 235240, AMNH 235241, AMNH 235233, AMNH 235242o, AMNH 235237\%, AMNH 235244, AMNH 235243\%, AMNH 235245\%, AMNH 235246\%, AMNH 235250\%, AMNH 235248\%, FMNH 22530\%, FMNH 123765o, FMNH 199823o, FMNH 60690", FMNH 1236580", FMNH 1507360", FMNH 23447o", MVZ 342620", MVZ 1220520", MVZ 772960", MVZ 772950".

Mustela sibirica - AMNH 854140", AMNH 85430 ', AMNH 854400", AMNH

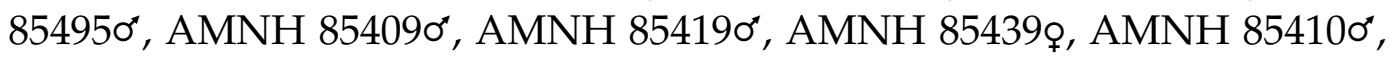
AMNH 85413\%, AMNH 854110", AMNH 854120", AMNH 45354, AMNH

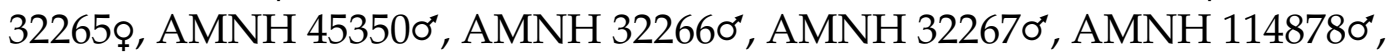
AMNH 114880 "', AMNH 110469o, AMNH 1104670", AMNH 1104710", AMNH 110468\%, FMNH 359950", FMNH 359940", FMNH 46040。, FMNH 460410", FMNH 189220", FMNH 189210", FMNH 459760", FMNH 410160", FMNH 378050", 
FMNH 37806 ", FMNH 366950", FMNH 378070", FMNH 378040", FMNH366940", FMNH 35465 "', FMNH 1043920", MVZ 412080", MVZ 304840".

Mustela subpalmata - USNM 2832680, USNM 283267\%, USNM 283266o, USNM 277284, USNM 277282o, USNM 2772830", USNM 3171010", USNM 3171020", USNM 317104o", USNM 3171030", MVZ 107719ㅇ. .

Mustela vison - MVZ 192980", MVZ 120120", MVZ 12016o, MVZ 120140", MVZ 12015o, MVZ 120130", MVZ 12011@, MVZ 904450", MVZ 441400", MVZ 24731, MVZ 24730@, MVZ 246400", MVZ 23690@, MVZ 23659o", MVZ 69090o", MVZ 13774ㅇ, MVZ 38924, MVZ 441410", MVZ 34164ㅇ, MVZ 230510", MVZ 23050@, MVZ 23049@, MVZ 36464, MVZ 34237o", MVZ 33620\%, MVZ 31112q, MVZ 311110", MVZ 349560", MVZ 349550", MVZ 10851, MVZ 108500", MVZ 247710", MVZ 247670", MVZ 247660", MVZ 236660", MVZ 278520", MVZ39882ᄋ, MVZ 13775o, MVZ 129050", MVZ 129040", MVZ 129030".

Poecilogale albinucha - AMNH 1186140, AMNH 119660"', AMNH 864910", AMNH 1163220", AMNH 1808900", AMNH 86490\%, FMNH 26050"', FMNH 26047o, FMNH 26053o, FMNH 260560", FMNH 26054, FMNH 26340。, FMNH 26338\%, FMNH 26341\%, FMNH 263420", FMNH 26344o, FMNH 26345o, FMNH 26349 "', FMNH 263470", FMNH 26348。, FMNH 27580。, FMNH 275820", FMNH 27585o, FMNH 27587o, FMNH 27588。, FMNH 38145o, FMNH 26546o, FMNH 36039o, FMNH 149355o, FMNH 1772360", FMNH 1772350", FMNH 2147270", USNM 377040。.

Pteronura brasiliensis - AMNH 777350", AMNH 214394o, AMNH 735870", AMNH 917110", AMNH 917120", AMNH 937320", AMNH 74431。, AMNH 71858\%, AMNH 744300", AMNH 74432o, AMNH 301900", AMNH 30191\%, AMNH 985940", AMNH 928340", FMNH 20015o, FMNH 412330", FMNH 707680", FMNH 980780", MN 772310", MN 50803。, MN 67470\%, MN 42695o, MN 73635o, MN 327000", MN 508020, MPEG 56020", MPEG 5605o, MPEG 56030", MPEG 5604, MPEG 6850", MPEG 56520", MZUSP 16580, MZUSP 7018。, MZUSP 70250", MZUSP 7019。, MZUSP 7024, MZUSP 23230", MZUSP 70200", MZUSP 70220", MZUSP 7021, MZUSP 323750", MZUSP 5173。, MZUSP 58900 .

Taxidea taxus - MVZ 1017769o, MVZ 24733o, MVZ 121834, MVZ1145820", MVZ 46656o, MVZ 7076o, MVZ 1244310", MVZ 1546990", MVZ 1244310", MVZ 113360", MVZ 1659130", MVZ 90625, MVZ 879580", MVZ 597550", MVZ 2250230", MVZ 32964o, MVZ 197460", MVZ 34166。, MVZ 19747o, MVZ 70780", MVZ 1841300", MVZ 40629o", MVZ 406280", MVZ 40627o", MVZ 40626o", MVZ 677750", MVZ 84959o, MVZ 46527o, MVZ 459040", MVZ 372800", MVZ 8277o", MVZ 82760", MVZ 908550", MVZ 762510", MVZ 414630", MVZ 41465o, MVZ 414660", MVZ 41467ه", MVZ 97200。, MVZ 41500o".

Vormela peregusna - AMNH 1833580, FMNH 112447\%, FMNH 1039640", FMNH 112448@, FMNH 48482。, USNM 2003220", USNM 2003210", USNM 15996\%, USNM 154995\%, USNM 2007920. 
Apêndice B

Comparação entre medidas de

similaridade de matrizes 
Comparação de matrizes é uma tópico de intenso debate, principalmente no contexto de genética quantitativa, na qual a estabilidade das matrizes de covariância fenotípica/genotípica tem importantes consequências para o estudo de evolução em escala micro (e.g. Brodie III, 1993; Whitlock et al., 2002; Wood e Brodie, 2015; Careau et al., 2015; Roff, 2000; Puentes et al., 2016) e macroevolutiva (e.g. Roff, 2000; Arnold et al., 2008; Roff, 2003; Prôa et al., 2013,3). Ao longo dos anos, diversas estatísticas de comparação de matrizes foram desenvolvidas e empregadas neste contexto (e.g. Flury, 1987, 1984; Cheverud et al., 1983; Roff, 2002; Cheverud e Marroig, 2007; Hansen e Houle, 2008; Calsbeek e Goodnight, 2009; Mitteroecker e Bookstein, 2009; Roff et al., 2012; Garcia, 2012). Abaixo eu comparo quatro medidas atualmente implementados no pacote produzido pelo laboratório EVOLQG (Melo et al., 2015): RS, correlação de matrizes, $K r z_{\text {Cor }}, P C A_{\text {sim }}$.

O método RS foi explicado em detalhes no Capítulo 2. Correlação de matrizes, nada mais é do que o coeficiente de correlação de Pearson dos elementos não-diagonais das matrizes sendo comparadas. A correlação de $\mathrm{Kr}-$ zanowski (1979) mede a similaridade dos subespaços definidos pelos principais eixos de variação (componentes principais, PCs) das matrizes sendo comparadas. A correlação de Krzanowski entre duas matrizes A e B é calculada como

$$
\operatorname{Kr} z_{\text {Cor }}(A, B)=\frac{1}{k} \sum_{i=1}^{k} \sum_{j=1}^{k} \cos ^{2} \theta_{i j}
$$

onde $k$ é o numero de componentes principais selecionados, $\theta_{i j}$ é o ângulo entre o PC $i$ da primeira matriz e o PC $j$ da segunda matriz. Se usarmos todos os PCs de ambas matrizes, $\mathrm{Krz}_{\mathrm{Cor}}(A, B)$ é igual a 1 . Sendo assim, sugere-se avaliar apenas um subconjunto de PCs para produzir uma estatística informativa, normalmente a metade menos um (17 PCs no presente caso).

Visto que essa estatística não leva em conta a variância explicada por 
cada PC, Singhal e Seborg (2006) propôs o uso de uma derivação da correlação de Krzanowski chamada PCA similarity, e é calculada como

$$
\operatorname{PCA}_{\text {sim }}(A, B)=\frac{\sum_{i=1}^{k} \sum_{j=1}^{k}\left(\lambda_{i}^{A} \lambda_{j}^{B}\right) \cos ^{2} \theta_{i j}}{\sum_{i=1}^{k} \lambda_{i}^{A} \lambda_{i}^{B}}
$$

onde $\lambda_{i}^{A}$ e $\lambda_{j}^{B}$ são os autovalores $i$ e $j$ das matrizes $A$ e $B$ respectivamente. Note que essa estatística, diferente da correlação original de Krzanowski por avaliar todos os PCs. Assim o $P C A_{\text {sim }}$ avalia não apenas o alinhamento relativo dos autovetores de ambas as matrizes, como também a quantidade de variação contida em cada um deles.

\section{Métodos}

As similaridades de matrizes, tanto de covariância quanto de correlação, foram estimadas par-a-par produzindo, para cada estatística, uma matriz de similaridade entre espécies. Isso resultou em oito matrizes par-a-par (quatro estatísticas, dois tipos de matrizes), que foram comparadas entre si por correlação de matrizes. Para ilustrar o padrão evidenciado em cada matriz de similaridade eu empreguei dois métodos gráficos. O primeiro consiste em produzir um "mapa de calor", onde a intensidade de similaridade de matrizes é expressa através de uma escala de cor. O segundo método emprega Análises de Coordenadas Principais (PCOA) para resumir a variação entre matrizes a poucos eixos de variação.

PCOA é uma análise de decomposição espectral aplicada em uma matriz de distâncias, ao invés de uma matriz de variância-covariância. Assim, os autovetores obtidos através de uma PCOA representam os valores das observações nos eixos de máxima variação daquele espaço. Para um espaço euclidiano, a dispersão das observações em um PCOA é equivalente às projeções das variáveis originais nos autovetores de uma PCA regular. Visto 
que o método requer a utilização de uma matriz de distância, eu obtive $1-S$, onde $S$ é a matriz de similaridades obtidas pelas diversas estatísticas. A matriz resultante é uma matriz de dissimilaridade e pode ser analisada regularmente por PCOA.

A seguir apresento a comparação entre os diferentes métodos quando aplicados nas matrizes de covariância e correlação. Foram obtidas as estatísticas de similaridade para todas as espécies com mais de 24 espécimes e as repetibilidades foram calculadas através de 1000 réplicas por Monte Carlo.

\section{Resultados}

Para matrizes de covariância os valores médios de similaridades corrigidos em ordem decrescente foram: $P C A_{\text {sim }}(0.82)$, seguidos por RS (0.80), Krz $z_{\text {or }}$ (0.78) e MatrixCor (0.60). Em termos de variação, $K r z_{\text {Cor }}$ apresentou o menor desvio padrão (0.03), seguidos por RS (0.08), $P C A_{\text {sim }}(0.08)$ e MatrixCor (0.14). Para matrizes de correlação os padrões foram similares $\left(P C A_{\text {sim }}=\right.$ $0.82 \pm 0.05 ; R S=0.80 \pm 0.05, K r z_{\text {Cor }} .=0.77 \pm 0.03$ e MatrixCor $=0.57 \pm$ 0.10). Tanto RS quanto $P C A_{\text {sim }}$ apresentaram similaridades de matrizes de correlação mais elevadas e menos variáveis do que as similaridades de covariâncias, enquanto similaridades por $K r z_{C o r}$ e MatrixCor apresentaram valores mais similares entre os dois tipos de matriz, com uma leve tendência para valores mais baixos em matrizes de correlação (figura B.1).

Os valores de correlação entre as diferentes estatísticas foram similares para as similaridades corrigidas e observadas, e por isso foco na descrição dos padrões observados. Para matrizes de covariância, RS, $P C A_{\text {sim }}$ e correlação de matrizes apresentaram padrões de similaridade equivalentes (Tabela B.1, figura B.2), com correlações entre as diferentes estatísticas superiores a 0.89 , enquanto todas as correlações com $\mathrm{K} r z_{\mathrm{Cor}}$ foram inferiores a 0.43 . Para matrizes de correlação o padrão foi similar, com exceção do fato de as 

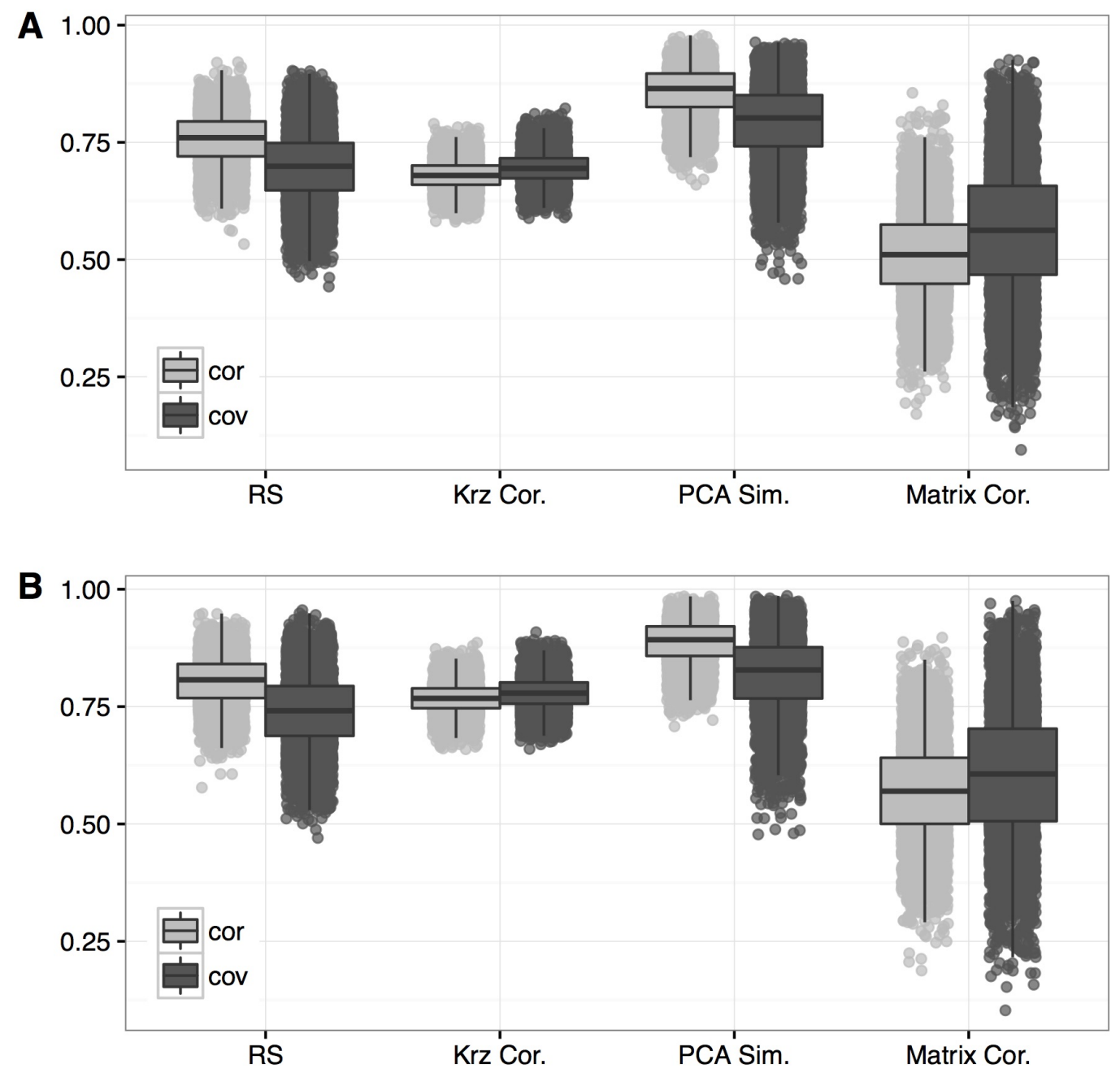

Figura B.1: Comparação das estatísticas de similaridade de matrizes. AValores observados. B- Valores corrigidos para repetibilidade. RS- Random Skewers, KrzCor.- Correlação de Krzanowski, PCASim.- PCA similarity, MatrixCor.- Correlação de matrizes. cov- Matrizes de covariância, cor- Matrizes de correlação. 
Tabela B.1: Correlação entre medidas de similaridade de matrizes. Caselas em cinza representam comparações entre matrizes de covariância e correlação para a mesma estatística. Valores em negrito se referem a comparações para matrizes de covariância, e valores sublinhados se referem a comparações para matrizes de correlação. RS- Random Skewers, KrzCor- Correlação de Krzanowski, PCA $A_{\text {sim- }}$ PCA similarity, Matrix Cor.- Correlação de matrizes.

\begin{tabular}{|c|c|c|c|c|c|c|c|c|c|}
\hline \multirow[b]{2}{*}{ Observados } & & \multicolumn{2}{|c|}{ RS } & \multicolumn{2}{|c|}{ KrzCor } & \multicolumn{2}{|c|}{$P C A_{\text {sim }}$} & \multicolumn{2}{|c|}{ Matrix Cor. } \\
\hline & & cov & cor & $\mathrm{cov}$ & cor & $\mathrm{cov}$ & cor & cov & cor \\
\hline \multirow{2}{*}{ RS } & $\mathrm{COV}$ & 1.0000 & 0.7032 & 4256 & 0.5114 & 0.8989 & 0.5886 & 0.9085 & 0.6369 \\
\hline & cor & 0.7032 & 1.0000 & 0.3258 & $\underline{0.3988}$ & 0.6563 & $\underline{0.8902}$ & 0.6295 & $\underline{0.7455}$ \\
\hline \multirow{2}{*}{ KrzCor } & $\mathrm{COV}$ & 0.4256 & 0.3258 & 1.0000 & 0.7296 & 0.2896 & 0.1815 & 0.2987 & 0.3575 \\
\hline & cor & 0.5114 & $\underline{0.3988}$ & 0.7296 & 1.0000 & 0.4368 & $\underline{0.2912}$ & 0.4568 & 0.4388 \\
\hline \multirow{2}{*}{$P C A_{\text {sim }}$} & $\mathrm{COV}$ & 0.8989 & 0.6563 & 0.2896 & 0.4368 & 1.0000 & 0.7075 & 0.9241 & 0.6182 \\
\hline & cor & 0.5886 & $\underline{0.8902}$ & 0.1815 & 0.2 & 0.7075 & 1.0000 & 0.5988 & $\underline{0.6912}$ \\
\hline \multirow{3}{*}{$\begin{array}{l}\text { Matrix Cor. } \\
\text { Corrigidos }\end{array}$} & $\mathrm{COV}$ & 0.9085 & 0.6295 & 0.2987 & 0.4 & 0.9241 & & 1.0000 & 0.6836 \\
\hline & cor & 0.6369 & $\underline{0.7455}$ & 0.3575 & $\underline{0.4388}$ & 0.6182 & $\underline{0.6912}$ & 0.6836 & 1.0000 \\
\hline & & & & & & & & & \\
\hline \multirow{2}{*}{ RS } & $\mathrm{cov}$ & & 00 & & & 0.8949 & & 0.9126 & 0.6331 \\
\hline & cor & 0 & $\underline{1.0000}$ & 0.3070 & $\underline{0.3689}$ & 0.6108 & $\underline{0.8665}$ & 0.6186 & $\underline{0.7538}$ \\
\hline \multirow{2}{*}{ KrzCor } & $\mathrm{COV}$ & 0.4249 & 0.3070 & 1.0000 & 0.7348 & 0.2965 & 0.1710 & 0.3213 & 0.3567 \\
\hline & cor & 0.5043 & $\underline{0.3689}$ & 0.7348 & $\underline{1.0000}$ & 0.4184 & $\underline{0.2459}$ & 0.4576 & $\underline{0.4263}$ \\
\hline \multirow{2}{*}{$P C A_{\text {sim }}$} & $\mathrm{COV}$ & 0.8949 & 0.6108 & 0.2965 & 0.4184 & 1.0000 & 0.6751 & 0.9268 & 0.6031 \\
\hline & cor & 0.5685 & $\underline{0.8665}$ & 0.1710 & $\underline{0.2459}$ & 0.6751 & $\underline{1.0000}$ & 0.5926 & $\underline{0.7141}$ \\
\hline \multirow{2}{*}{ Matrix Cor. } & $\mathrm{cov}$ & 0.9126 & 0.6186 & 0.3213 & 0.4576 & 0.9268 & 0.5926 & 1.0000 & 0.6753 \\
\hline & cor & 0.6331 & $\underline{0.7538}$ & 0.3567 & $\underline{0.4263}$ & 0.6031 & $\underline{0.7141}$ & 0.6753 & 1.0000 \\
\hline
\end{tabular}

correlações entre $P C A_{\text {sim }}$ e RS com MatrixCor serem mais reduzidas $(0.69$ e 0.75 respectivamente). Adicionalmente, para matrizes de covariância há uma padronização evidente nas similaridade para todas as estatísticas, com a família Canidae apresentando valores mais elevados de similaridade entre si do que com outros grupos (ver capítulo 3), com a exceção aparente de $K r z_{\text {Cor }}$ (figura B.2). Apesar disso, esse padrão não foi evidente quando as mesmas estatísticas foram calculadas sob as matrizes de correlação (figura B.3).

De forma resumida, podemos dizer que as matrizes de correlação se mostraram mais similares (ao menos segundo RS e $P C A_{\text {sim }}$ ) do que as matrizes de covariância. A estatística $K r z_{\text {Cor }}$ se demonstrou a mais estável, com pouca variação tanto para matrizes de covariância quanto de correlação. RS, $P C A_{\text {sim }}$ e MatrixCor apresentam padrões de similaridade altamente corre- 

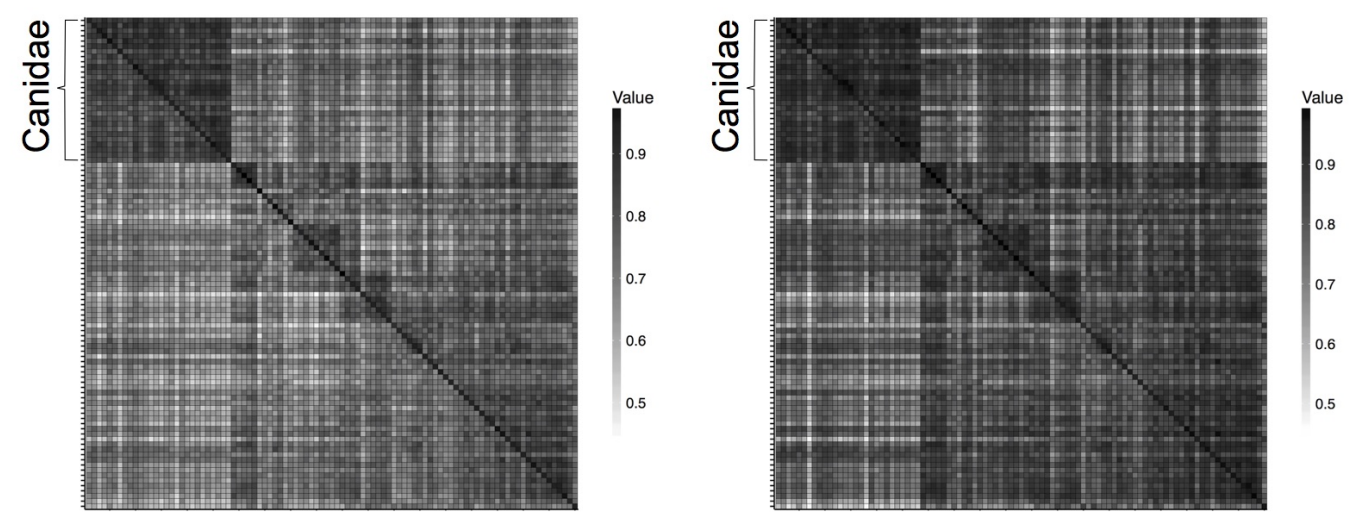

KrzCor

MatrixCor
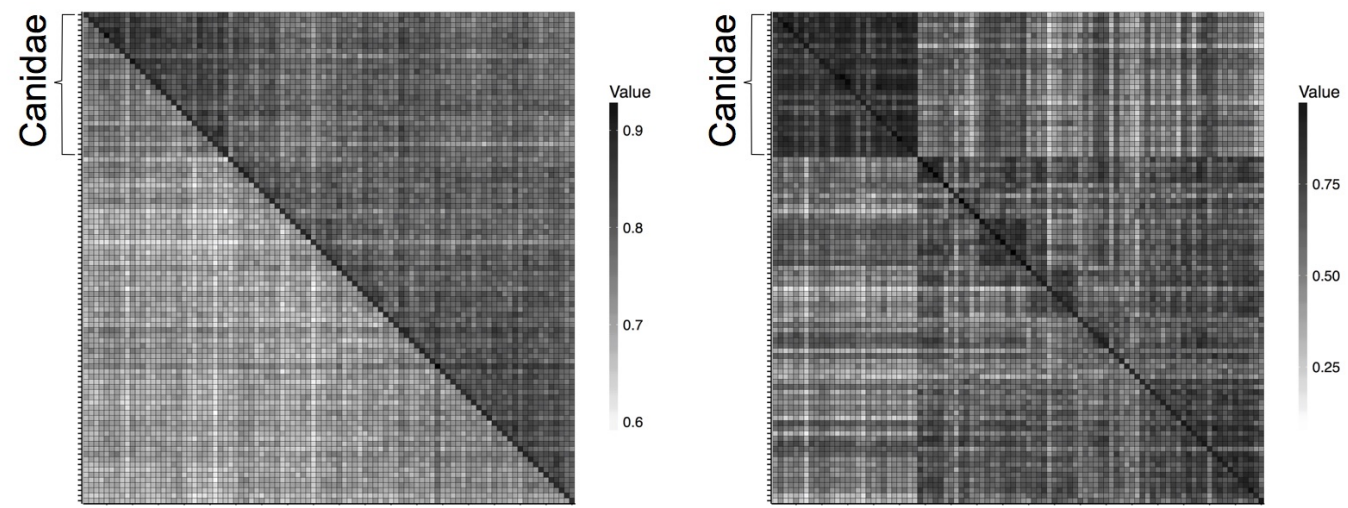

Figura B.2: Mapa de calor de similaridade de matrizes de covariância segundo diferentes estatísticas. Valores mais claros são menores e valores mais escuros são maiores. RS- Random Skewers, KrzCor- Correlação de Krzanowski, PCAsim- PCA similarity, Matrix Cor.- Correlação de matrizes. 

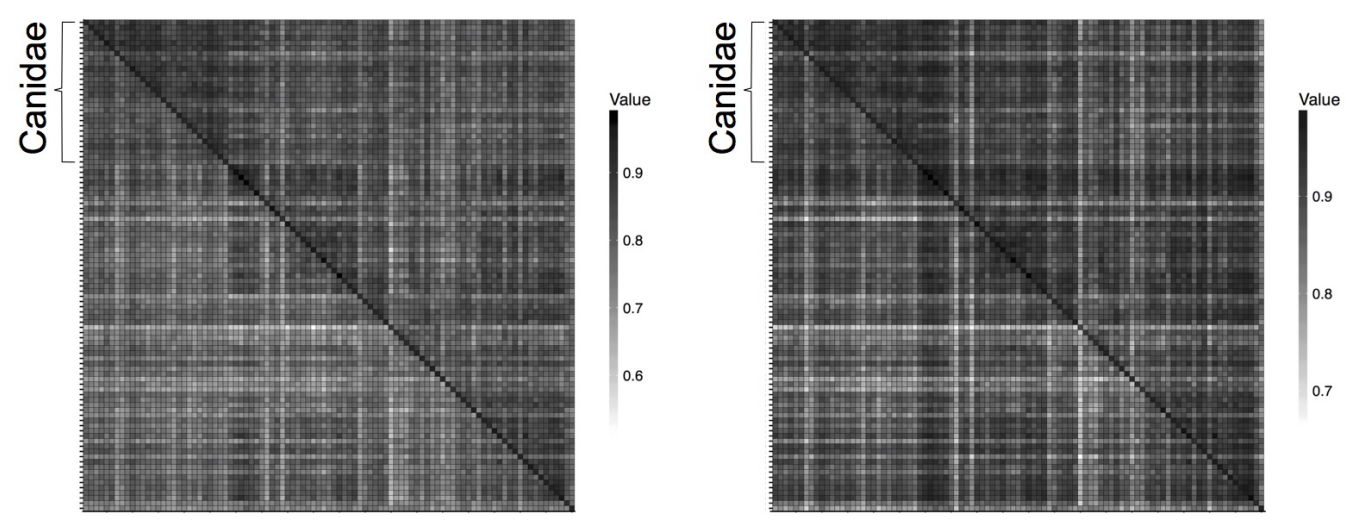

KrzCor

MatrixCor
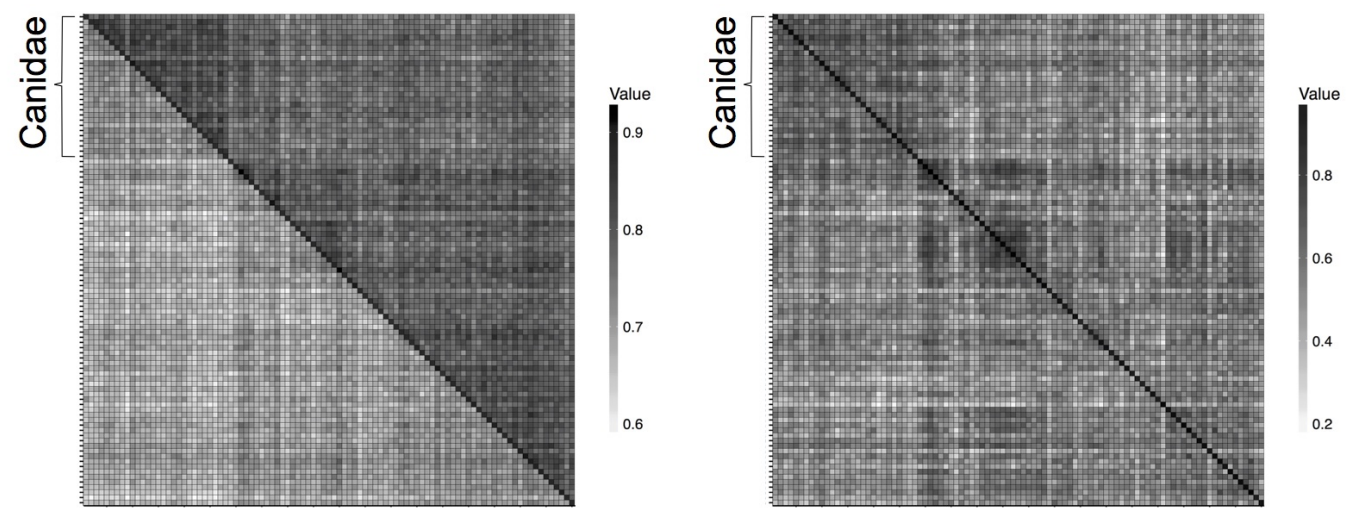

Figura B.3: Mapa de calor de similaridade de matrizes de correlação segundo diferentes estatísticas. Valores mais claros são menores e valores mais escuros são maiores. RS- Random Skewers, KrzCor- Correlação de Krzanowski, PCAsim- PCA similarity, Matrix Cor.- Correlação de matrizes. 
lacionado, apesar de diferirem muito em valor absoluto, com $P C A_{\text {sim }}$ apresentando os maiores valores de similaridade e MatrixCor os menores.

A inspeção dos gráficos de PCOA para as matrizes de covariância (Figura B.4) e correlação (Figura B.5) demonstram que, apesar de haver diferenças entre os gráficos como seria esperado através das análises de correlação, Canidae sempre emerge como um grupo particularmente distinto dos demais Caniformes. A investigação da relação das distâncias Riemmanianas entre matrizes (Mitteroecker e Bookstein, 2009; Bookstein e Mitteroecker, 2013) produziu um resultado muito similar ao observado para outras estatísticas (Figura C.3), principalmente para RS (Figura B.4), com a exceção da inversão do eixo que discrimina Canidae dos demais Caniformes. $\mathrm{O}$ resultado desta investigação preliminar foi exposto em formato de poster durante a reunião Evolution 2015 e pode ser visto no Apêndice C.

Essas comparações sugerem que estatísticas diferentes podem apresentar valores médios e variâncias distintas e mesmo assim evidenciar o mesmo padrão de similaridades entre os grupos. Isso se deve provavelmente ao fato de que todas as estatísticas avaliam aspectos comuns da matriz, mesmo que a similaridade entre duas matrizes seja calculadas de forma diferente. Isso parece ser particularmente válido para RS, $P C A_{\text {sim }}$ e MatrixCor, os quais avaliam a matriz como um todo e apresentaram correlações altas entre si. $K r z_{\text {Cor }}$ distoou desse padrão, apresentando correlações baixas com demais medidas sugerindo que, ao não quantificar a distribuição de variação nos diversos autovetores das matrizes, essa medida não reflete bem a capacidade de responder similarmente à seleção, como medido por RS. 

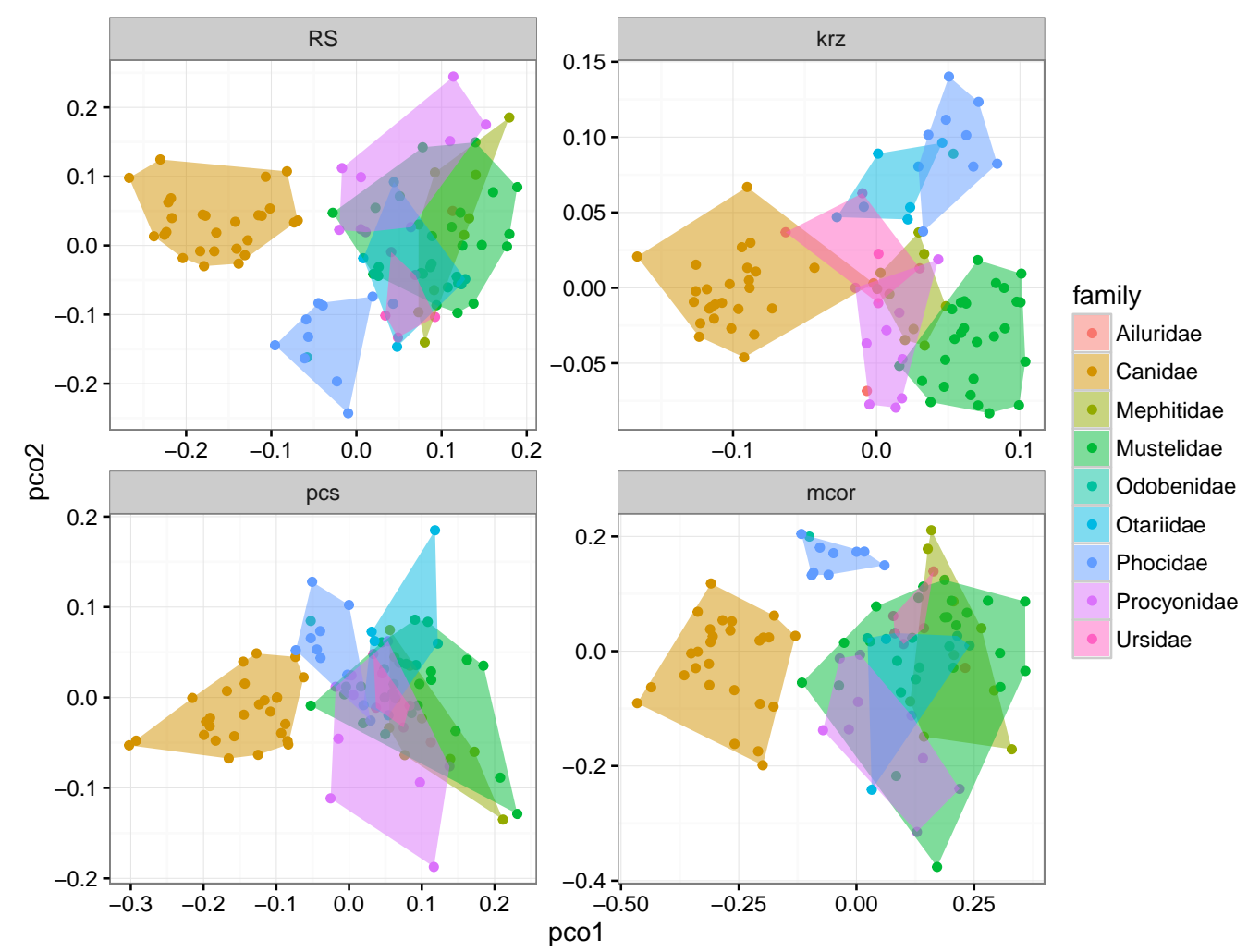

Figura B.4: Análise de Coordenadas Principais das similaridades de matrizes por $R S, K r z_{\text {Cor }}(\mathrm{krz}), P C A_{\text {sim }}$ (pcs) e $M_{\text {cor }}$ (mcor) para matrizes de covariância. 

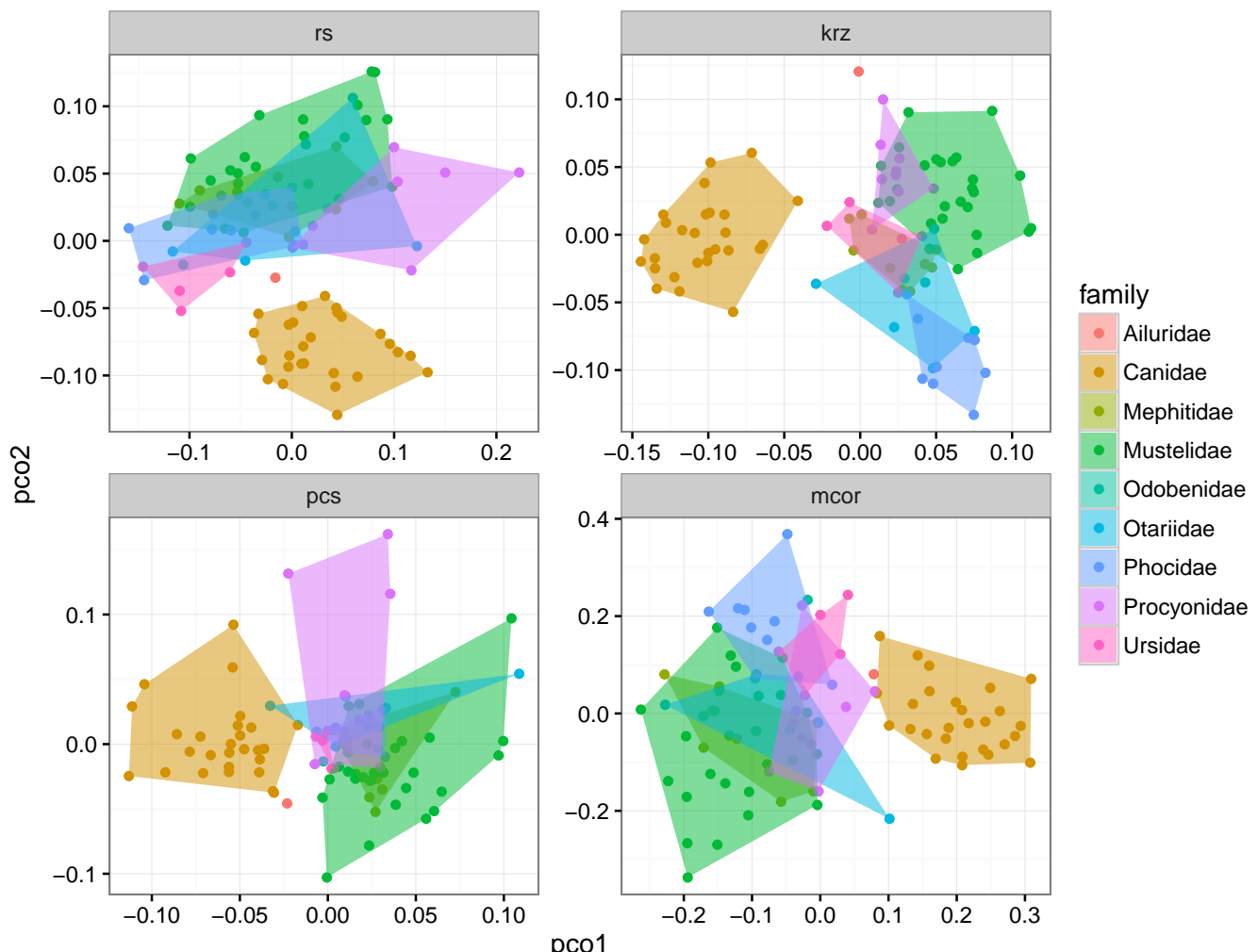

Figura B.5: Análise de Coordenadas Principais das similaridades de matrizes por $R S, K r z_{\text {Cor }}(\mathrm{krz}), P C A_{\text {sim }}$ (pcs) e $M_{\text {cor }}$ (mcor) para matrizes de correlação. 


\section{Referências Bibliográficas}

Arnold, S. J., Bürger, R., Hohenlohe, P. A., Ajie, B. C., e Jones, A. G. (2008). Understanding the evolution and stability of the G-matrix. Evolution, 62(10):2451-2461.

Bookstein, F. L. e Mitteroecker, P. (2013). Comparing Covariance Matrices by Relative Eigenanalysis, with Applications to Organismal Biology. Evolutionary Biology.

Brodie III, E. D. (1993). Homogeneity of the genetic variance-covariance matrix for antipredator traits in two natural Garter Snake, Thamnophis ordinoides. Evolution, 47(3):844-854.

Calsbeek, B. e Goodnight, C. J. (2009). Empirical comparison of G matrix test statistics: finding biologically relevant change. Evolution, 63(10):26272635.

Careau, V., Wolak, M. E., Carter, P. A., e Garland, T. (2015). Evolution of the additive genetic variance-covariance matrix under continuous directional selection on a complex behavioural phenotype. Proceedings of the Royal Society of London. Series B, Biological Sciences, 282(1819).

Cheverud, J. M. e Marroig, G. (2007). Comparing covariance matrices: random skewers method compared to the common principal components model. Genetics and Molecular Biology, 30:461-469.

Cheverud, J. M., Rutledge, J., e Atchley, W. (1983). Quantitative genetics of development: genetic correlations among age-specific trait values and the evolution of ontogeny. Evolution, 37(5):895-905.

Flury, B. K. (1987). Two generalizations of the common principal component model. Biometrika, 74(1):59-69.

Flury, B. N. (1984). Common principal components in k groups. Journal of the American Statistical Association, 79(388):892-898.

Garcia, C. (2012). A simple procedure for the comparison of covariance matrices. BMC Evolutionary Biology, 12(1):222.

Hansen, T. e Houle, D. (2008). Measuring and comparing evolvability and constraint in multivariate characters. Journal of Evolutionary Biology, 21(5):1201-1219.

Krzanowski, W. J. (1979). Between-groups comparison of principal components. Journal of the American Statistical Association, 74(367):703-707.

Melo, D., Garcia, G. R. G., Hubbe, A., Assis, A. P., e Marroig, G. (2015). EvolQG - An R package for evolutionary quantitative genetics. F1000Research, 4(925):1-9. 
Mitteroecker, P. e Bookstein, F. L. (2009). The ontogenetic trajectory of the phenotypic covariance matrix, with examples from craniofacial shape in rats and humans. Evolution, 63(3):727-737.

Prôa, M., O'higgins, P., e Monteiro, L. R. (2013). Type I error rates for testing genetic drift with phenotypic covariance matrices: a simulation study. Evolution, 67(1):185-195.

Puentes, A., Granath, G., e Ågren, J. (2016). Similarity in G matrix structure among natural populations of Arabidopsis lyrata. Evolution, 70(10):23702386.

Roff, D. (2000). The evolution of the G matrix: selection or drift? Heredity, $84(2): 135$.

Roff, D. (2002). Comparing G Matrices: A Manova Approach. Evolution, pgs. 1286-1291.

Roff, D. (2003). The constancy of the G matrix through species divergence and the effects of quantitative genetic constraints on phenotypic evolution: a case study in crickets. Evolution, 57(5):1107-1120.

Roff, D. A., Prokkola, J. M., Krams, I., e Rantala, M. J. (2012). There is more than one way to skin a G matrix. Journal of Evolutionary Biology, 25(6):1113-1126.

Singhal, A. e Seborg, D. E. (2006). Clustering multivariate time-series data. Journal of Chemometrics, 19(8):427-438.

Whitlock, M. C., Phillips, P. C., e Fowler, K. (2002). Persistence of changes in the genetic covariance matrix after a bottleneck. Evolution, 56(10):19681975.

Wood, C. W. e Brodie, E. D. (2015). Environmental effects on the structure of the G-matrix. Evolution, 69(11):2927-2940. 

Appendix C

Poster Evolution 2015 


\section{Introduction}

Evolutionary constraints are properties of populations that hinder the generation of variation of a given kind or bias the production of variants on a given direction Maynard-Smith et al. (1985). The interaction between constraints and the adaptive regime of a population can lead to different evolutionary outcomes Porto et al. (2015), thus being important in the understanding of macroevolutionary patterns of morphological variation.

The objective of the ongoing project is to investigate variation in morphological integration of the skull in caniform carnivorans, and the potential constraints that these might entail. Here, we investigate the similarities and differences in patterns of morphological integration within the group Caniformes. This is done by the investigation of the phenotypic covariance matrix $\mathbf{P}$, which contains information about the variation and correlation of phenotypic characters. P (and its genetic counterpart $\mathbf{G}$ ) matrices are never expected to be identical between populations due to its finite size (sampling effects) not to mention differences in local selection Marroig and Cheverud (2001). For that reason, it is important not to evaluate if species diverge in pattern of covariation, but if the observed differences are large enough to produce different evolutionary outcomes. Thus, we use quantitative genetic theory to evaluate how similarly species would respond to natural selection.

\section{Materials}

We analyzed a total of 4,708 specimens from 104 species. Morphometric measurements were obtained through digitized anatomical landmarks of the skull (Figure C.1) with the aid of a Microscribe MLX system. We estimated 33 interlandmark distances and calculated covariance matrices for these traits. 


\section{Methods}

Prior to $\mathbf{P}$ estimation, sources of variation that were not of interest (e.g. geographical/subspecies variation, sexual dimorphism, etc) were controlled for using a linear model approach.

To evaluate if species would respond similarly to natural selection, matrices were compared using the Random Skewers (RS) method and corrected for repeatability using non-parametric bootstrap. To illustrate the pattern of matrix similarity, we performed a principal coordinate analysis (PCO) over the Riemannian distance between the correlation matrices for 97 taxa with larger samples. The species on the extremes of the main axis of variation were investigated using the Selection Decomposition Vector (SRD) method.

To evaluate the variation in morphological integration in caniforms, we used the coefficient of variation of eigenvalues (ICV). The ICV is positively correlated with evolutionary constraints and negatively correlated with evolutionary flexibility Marroig et al. (2009).

\section{Results}

The results of the Random Skewers analyses were high, with a mean value of 0.736, ranging from 0.464-0.962 (Figure C.2). For the full sample, 95\% of all observations scored higher than 0.6 , but this value raises to 0.7 for within-family comparisons. When we look at individual families, Canidae and Phocidae show the $95 \%$ of the within family comparisons higher than 0.76, and for Ursidae the value is 0.73 . For Procyonids and Otariidae the value is closer to 0.7 and for Mephitidae and Mustelidae the values are 0.67 and 0.63 , respectively.

It is worth noting that species with small sample size tended to show lower values of RS on average. Nevertheless, these species showed high 


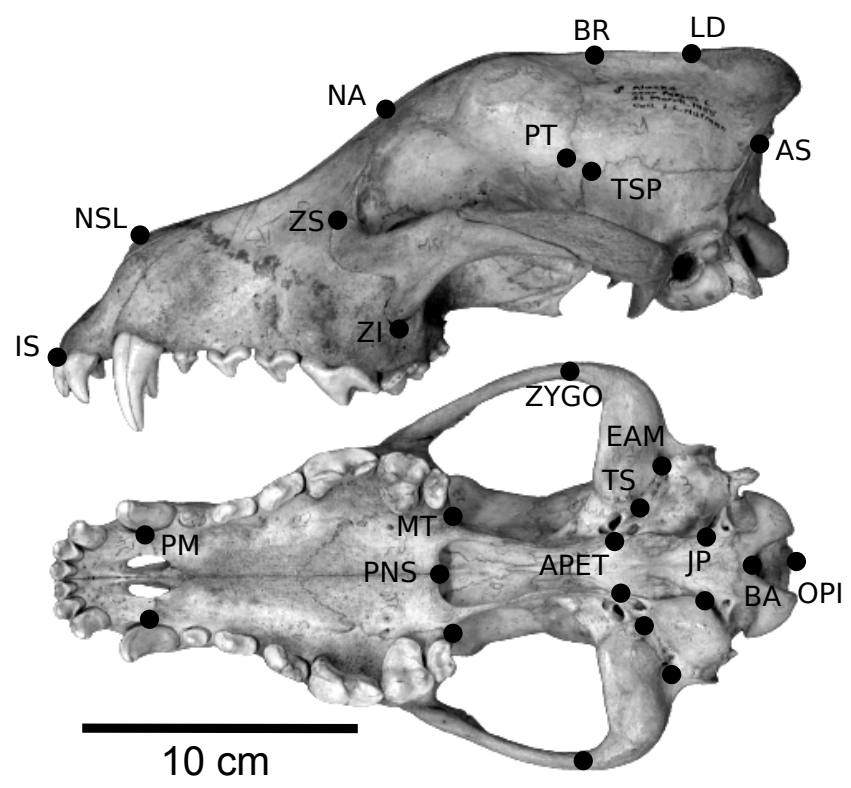

Figure C.1: Anatomical landmarks for this study exemplified in a Canis lupus skull in lateral and ventral views.

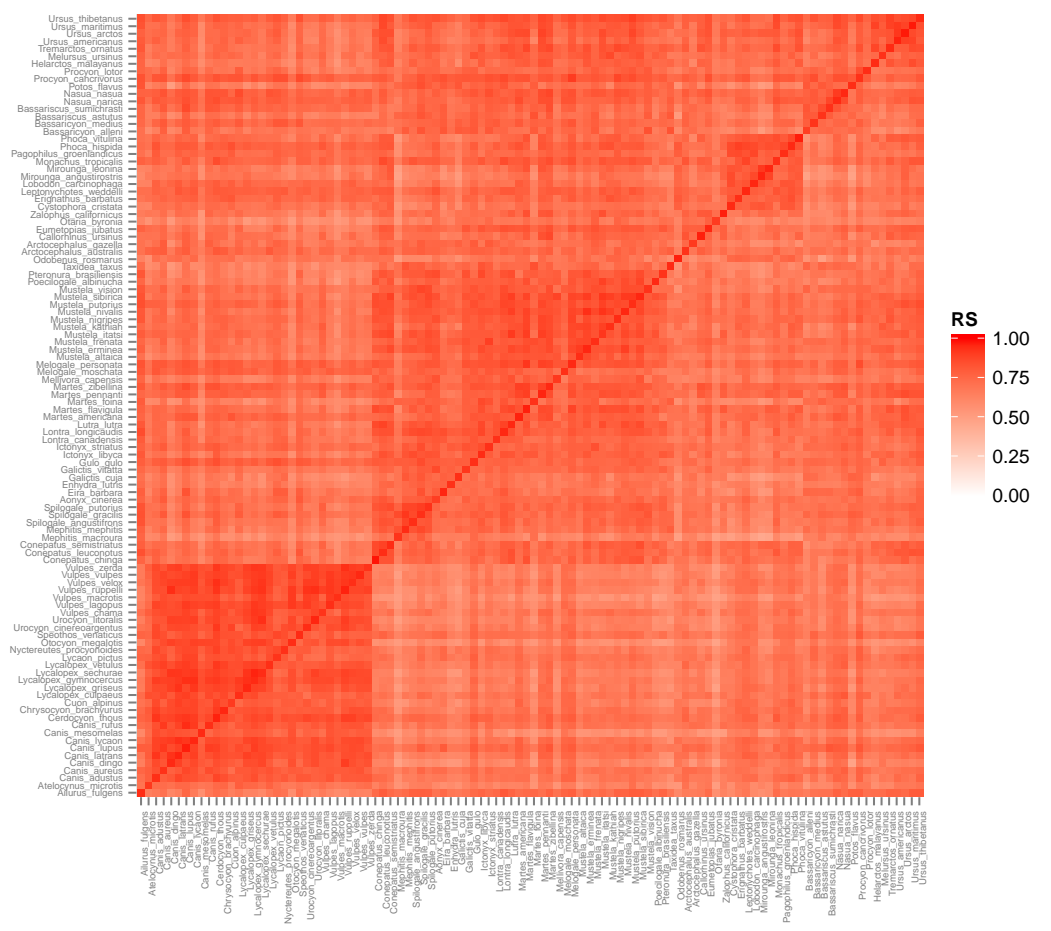

Figure C.2: Pairwise Random Skewers similarity for all 104 taxa. Cells on the diagonal are matrix repeatabilities. Values under diagonal are original values and values above it are corrected for repeatabilities. 
values when compared to closely related taxa.

The result of the principal coordinate analysis (Figure C.3) places Canidae into a distinct region of the PCO when compared to other families. Additionally, Mustelidae shows more variation in the first two PCO axes, occupying regions of the "matrix-space" not sampled by the other taxa. SRD analysis between species on extremes of the first PCO axis (not shown) suggests that differences associated with the posterior nasal, anterior zygomatic and base regions of the skull are responsible for the observed pattern.

The magnitude of integration as measured through ICV shows a broad variation within each family, with substantial overlap between families.

\section{Discussion}

Our results show that caniform carnivorans respond similarly to natural selection, with RS scores for comparisons within the same family showing higher values than comparisons between families, thus suggesting the presence of a phylogenetic patterning in the variation of $\mathbf{P}$ structure. In the PCO analysis, all families tended to cluster together, with the exception of Canidae, which shows no overlap with other families in the first axis, and Mustelidae, which overlaps with the other families but shows a wider distribution. ICV variation within families largely overlaps, suggesting that overall integration is not playing a major role in the observed differences of covariation patterns between families.

The results from SRD analyses of the extreme species on the first PCO axis indicate that the differences between Mustelids and Canidae are concentrated in regions that differ in structure between taxa. This might suggest that the divergence in $\mathbf{P}$ mirrors some aspects of the morphological variation between both groups and could be an indicative of the interaction of morphological diversification and patterns of morphological integration 


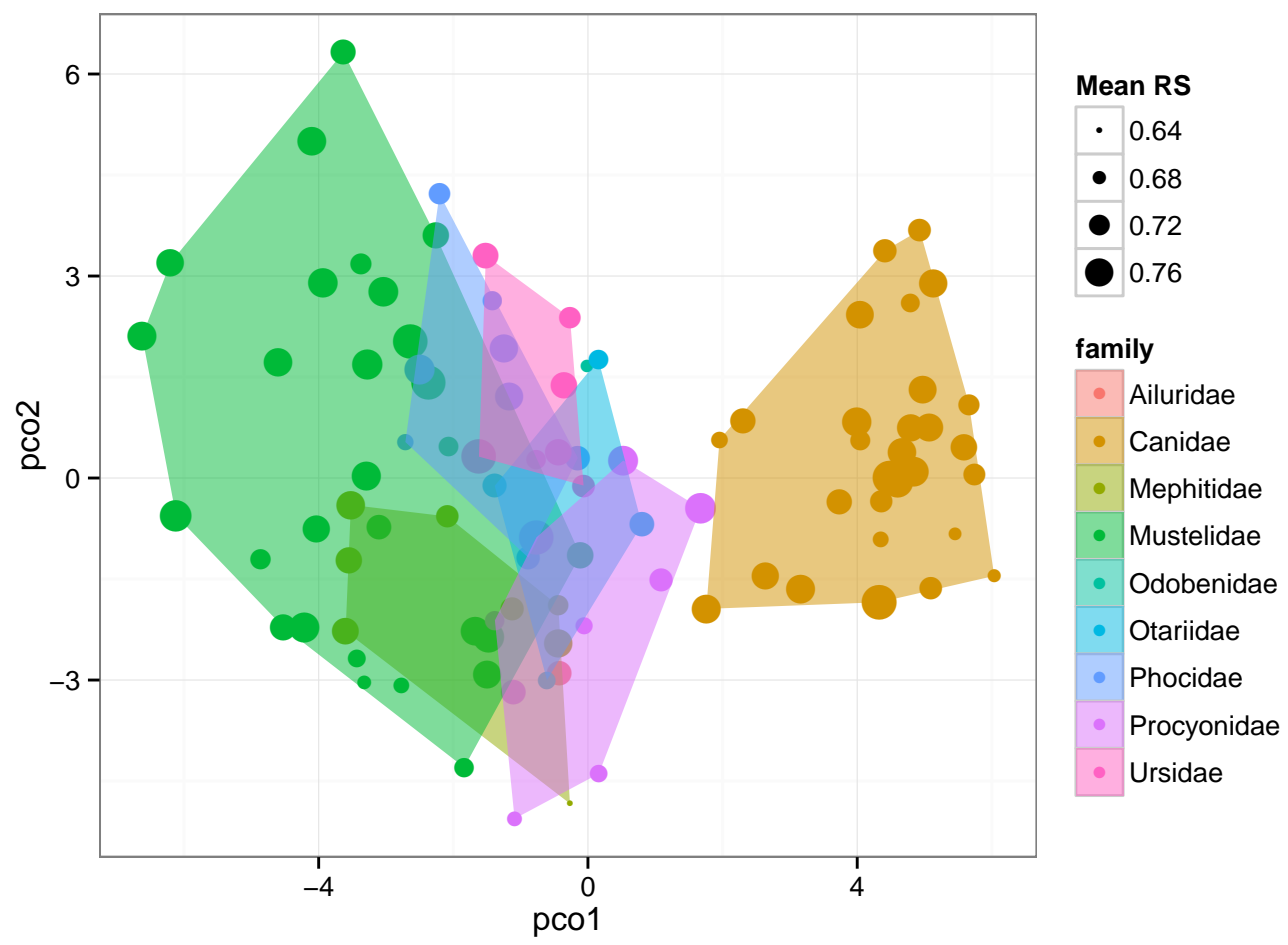

Figure C.3: Principal Coordinate Analysis of the pair-wise Riemannian distances between correlation matrices.

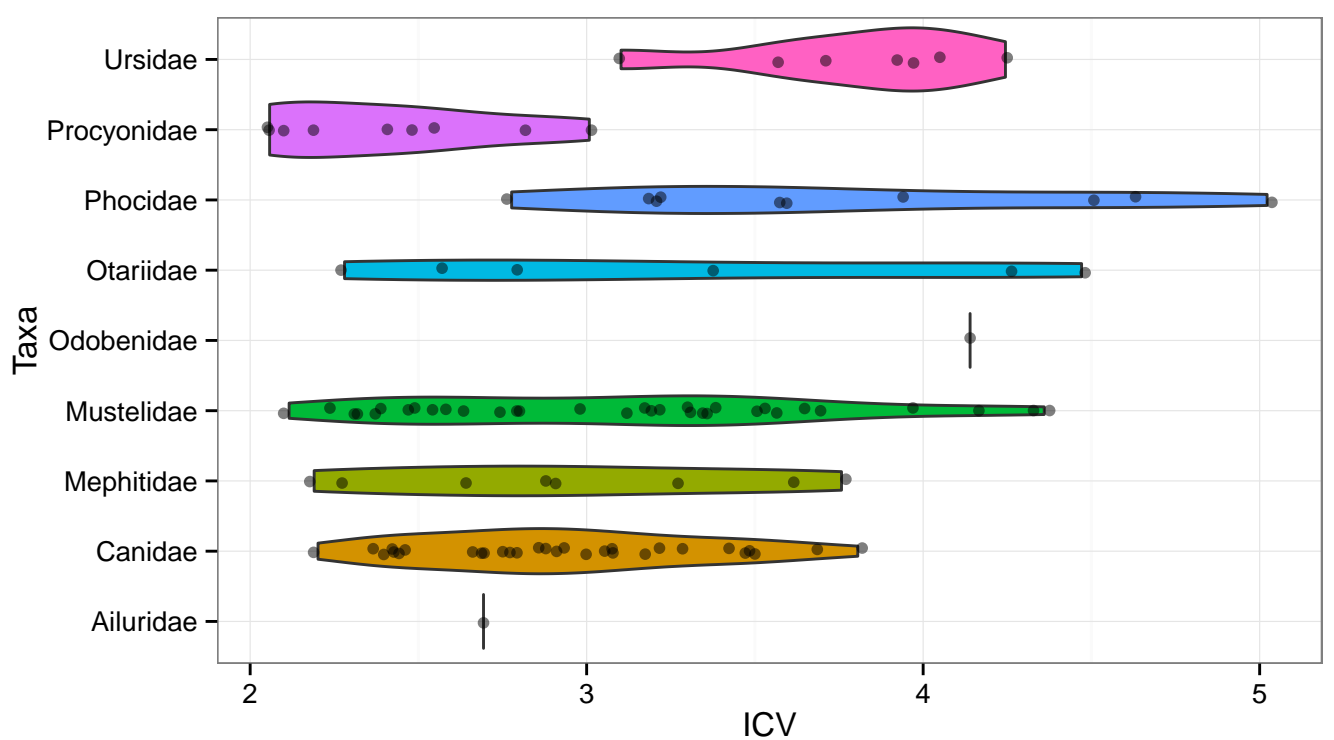

Figure C.4: Density distribution of morphological integration index (ICV) estimates. Dots represent individual species estimates. 
(e.g. Porto et al. (2015); Melo and Marroig (2015); Marroig and Cheverud (2005)). Future macroevolutionary studies will further elucidate the possible interplay between morphological diversification and variation in covariation patterns for this group.

\section{Acknowledgements}

We acknowledge the help of the curatorial staff from the following institutions: AMNH, ANSP, FMNH, MACN, MCZ, MLP, MNRJ, MPEG, MVZ, MZUSP , NMNH. We also thank FAPESP for financial support (grants No.2011/216744 and 2013/22042-7) 


\section{Bibliography}

Marroig, G. and Cheverud, J. M. (2001). A comparison of phenotypic variation and covariation patterns and the role of phylogeny, ecology, and ontogeny during cranial evolution of New World monkeys. Evolution, 55(12):2576-2600.

Marroig, G. and Cheverud, J. M. (2005). Size as a line of least evolutionary resistance: diet and adaptive morphological radiation in new world monkeys. Evolution, 59(5):1128-1142.

Marroig, G., Shirai, L. T., Porto, A., Oliveira, F. B. d., and Conto, V. (2009). The Evolution of Modularity in the Mammalian Skull II: Evolutionary Consequences. Evolutionary Biology, 36(1):136-148.

Maynard-Smith, J., Burian, R., Kauffman, S., Alberch, P., Campbell, J., Goodwin, B., Lande, R., Raup, D., and Wolpert, L. (1985). Developmental constraints and evolution: a perspective from the Mountain Lake Conference on Development and Evolution. The Quarterly Review Of Biology, 60(3):265-287.

Melo, D. and Marroig, G. (2015). Directional selection can drive the evolution of modularity in complex traits. Proceedings of the National Academy of Sciences of the United States of America, 112(2):470-475.

Porto, A., Sebastião, H., Pavan, S. E., VandeBerg, J. L., Marroig, G., and Cheverud, J. M. (2015). Rate of evolutionary change in cranial morphology of the marsupial genus Monodelphisis constrained by the availability of additive genetic variation. Journal of Evolutionary Biology, 28(4):973-985. 

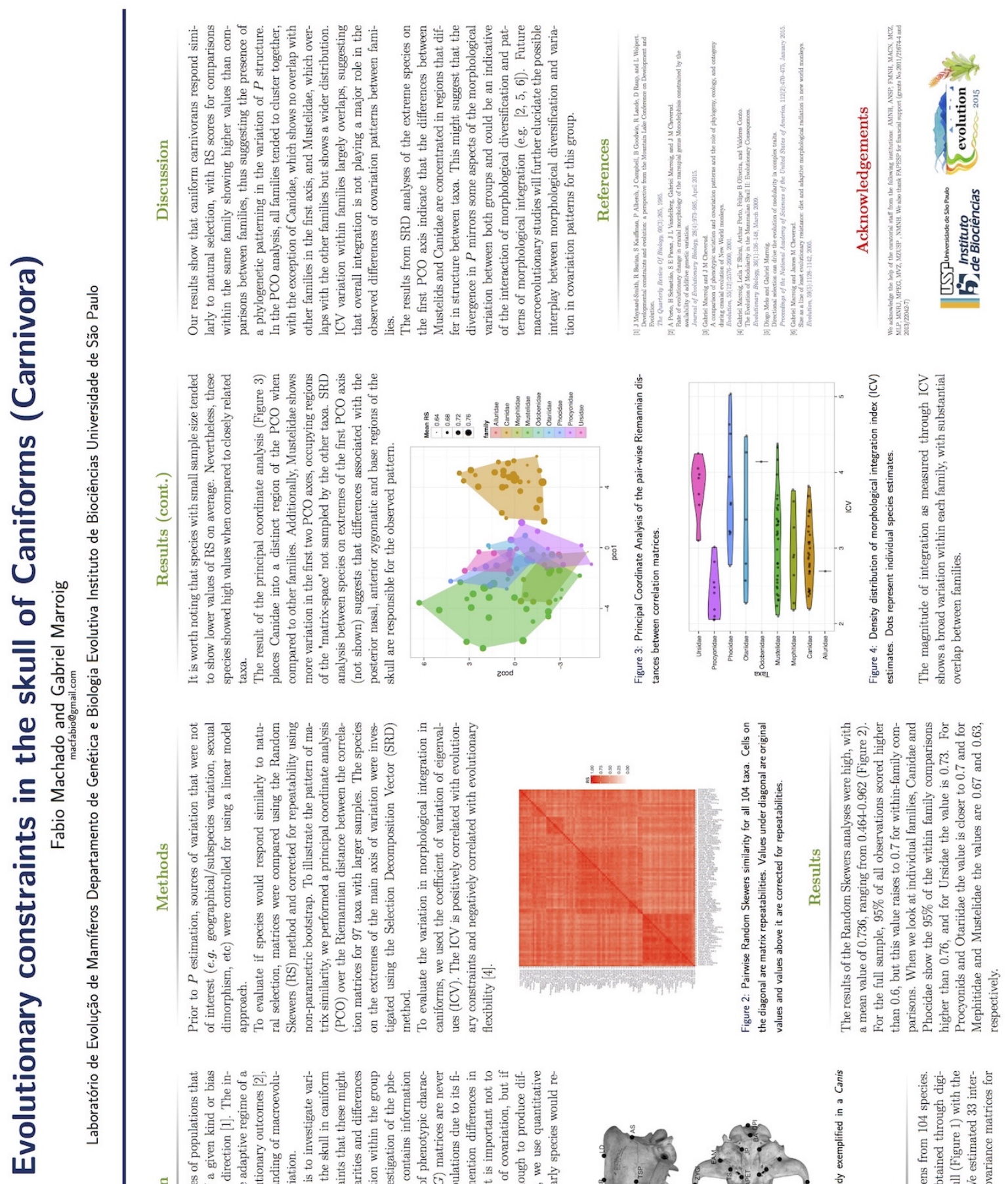

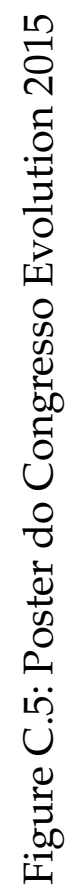
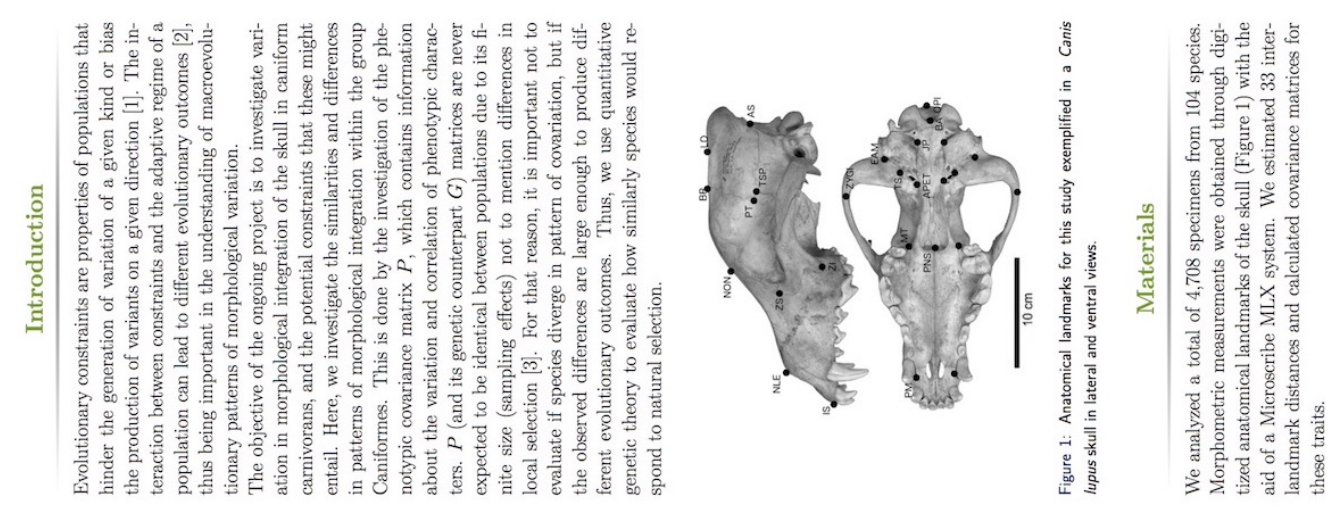

Appendix D

Apêndice do Capítulo 3 
Table D.1: Sample sizes and factors controled for each species analysed. SSPSubspecies or Geographical variation. SEX- sexual dimorphism. CAP- Captivity. AGE- Age cathegories. $\varnothing$ - no effects controled. + additive effects. * interaction effects.

\begin{tabular}{|c|c|c|c|c|}
\hline Family & Genus & Species & Control & $\mathrm{n}$ \\
\hline \multirow[t]{28}{*}{ Canidae } & \multirow[t]{9}{*}{ Canis } & Canis adustus & SSP+SEX & 38 \\
\hline & & Canis anthus & SSP+SEX & 54 \\
\hline & & Canis familiaris dingo & SSP+SEX & 46 \\
\hline & & Canis latrans & SSP & 61 \\
\hline & & Canis lupus & SSP+SEX & 107 \\
\hline & & Canis lycaon & $\varnothing$ & 48 \\
\hline & & Canis mesomelas & $\varnothing$ & 57 \\
\hline & & Canis rufus & SEX & 46 \\
\hline & & Lycaon pictus & SSP & 50 \\
\hline & Cerdocyon & Cerdocyon thous & $\varnothing$ & 77 \\
\hline & Chrysocyon & Chrysocyon brachyurus & $\varnothing$ & 57 \\
\hline & \multirow[t]{5}{*}{ Lycalopex } & Lycalopex culpaeus & SEX & 44 \\
\hline & & Lycalopex griseus & $\varnothing$ & 39 \\
\hline & & Lycalopex gymnocercus & SEX & 45 \\
\hline & & Lycalopex sechurae & $\varnothing$ & 37 \\
\hline & & Lycalopex vetulus & $\varnothing$ & 39 \\
\hline & Nyctereutes & Nyctereutes procyonoides & $\varnothing$ & 41 \\
\hline & Otocyon & Otocyon megalotis & SSP & 51 \\
\hline & Speothos & Speothos venaticus & $\varnothing$ & 56 \\
\hline & \multirow[t]{2}{*}{ Urocyon } & Urocyon cinereoargenteus & SEX & 44 \\
\hline & & Urocyon littoralis & SEX+SSP & 54 \\
\hline & \multirow[t]{7}{*}{ Vulpes } & Vulpes chama & $\varnothing$ & 26 \\
\hline & & Vulpes lagopus & SEX & 52 \\
\hline & & Vulpes macrotis & SEX & 48 \\
\hline & & Vulpes rueppellii & SEX & 58 \\
\hline & & Vulpes velox & $\varnothing$ & 37 \\
\hline & & Vulpes vulpes & SEX & 54 \\
\hline & & Vulpes zerda & $\varnothing$ & 45 \\
\hline \multirow[t]{5}{*}{ Ursidae } & Tremarctos & Tremarctos ornatus & $\varnothing$ & 28 \\
\hline & \multirow[t]{4}{*}{ Ursus } & Ursus americanus & SEX & 48 \\
\hline & & Ursus arctos & SEX & 67 \\
\hline & & Ursus maritimus & SEX & 84 \\
\hline & & Ursus thibetanus & $\mathrm{SSP}+\mathrm{CAP}$ & 46 \\
\hline Odobenidae & Odobenus & Odobenus rosmarus & $\varnothing$ & 60 \\
\hline \multirow[t]{6}{*}{ Otariidae } & \multirow[t]{2}{*}{ Arctocephalus } & Arctocephalus australis & SEX+SSP & 36 \\
\hline & & Arctocephalus gazella & $\varnothing$ & 35 \\
\hline & Callorhinus & Callorhinus ursinus & SEX & 55 \\
\hline & Eumetopias & Eumetopias jubatus & SEX & 53 \\
\hline & Otaria & Otaria byronia & SEX & 37 \\
\hline & Zalophus & Zalophus californianus & $\varnothing$ & 38 \\
\hline
\end{tabular}

Continues on next page 
Table D.1 - continued from previous page

\begin{tabular}{|c|c|c|c|c|}
\hline Family & Genus & Species & Control & $\mathrm{n}$ \\
\hline \multirow[t]{9}{*}{ Phocidae } & Cystophora & Cystophora cristata & SEX & 41 \\
\hline & Erignathus & Erignathus barbatus & $\varnothing$ & 39 \\
\hline & Leptonychotes & Leptonychotes weddellii & $\varnothing$ & 51 \\
\hline & Lobodon & Lobodon carcinophaga & $\varnothing$ & 44 \\
\hline & Mirounga & Mirounga leonina & SEX & 33 \\
\hline & Neomonachus & Neomonachus tropicalis & $\varnothing$ & 37 \\
\hline & Phoca & Phoca vitulina & SEX & 53 \\
\hline & Pusa & Pagophilus groenlandicus & $\varnothing$ & 47 \\
\hline & & Pusa hispida & $\varnothing$ & 51 \\
\hline \multirow[t]{9}{*}{ Mephitidae } & Conepatus & Conepatus chinga & $\varnothing$ & 92 \\
\hline & & Conepatus humboldtii & $\varnothing$ & 29 \\
\hline & & Conepatus leuconotus & SEX+SSP & 41 \\
\hline & & Conepatus semistriatus & $\varnothing$ & 39 \\
\hline & Mephitis & Mephitis macroura & SEX+SSP & 45 \\
\hline & & Mephitis mephitis & SEX+SSP & 47 \\
\hline & Spilogale & Spilogale angustifrons & $\varnothing$ & 43 \\
\hline & & Spilogale gracilis & SEX & 48 \\
\hline & & Spilogale putorius & SSP & 40 \\
\hline Ailuridae & Ailurus & Ailurus fulgens & $\varnothing$ & 48 \\
\hline \multirow[t]{9}{*}{ Procyonidae } & Bassaricyon & Bassaricyon alleni & SEX & 30 \\
\hline & & Bassaricyon medius & SEX & 40 \\
\hline & Bassariscus & Bassariscus astutus & SEX+SSP & 46 \\
\hline & & Bassariscus sumichrasti & SEX+SSP & 45 \\
\hline & Nasua & Nasua narica & SEX & 44 \\
\hline & & Nasua nasua & SEX+SSP & 60 \\
\hline & Potos & Potos flavus & SSP & 63 \\
\hline & Procyon & Procyon cancrivorus & SEX & 41 \\
\hline & & Procyon lotor & SEX & 52 \\
\hline \multirow[t]{5}{*}{ Mustelidae } & Eira & Eira barbara & SEX & 77 \\
\hline & Enhydra & Enhydra lutris & SEX & 43 \\
\hline & Galictis & Galictis cuja & SEX+SSP & 45 \\
\hline & & Galictis vittata & SEX+SSP & 34 \\
\hline & Gulo & Gulo gulo & SEX & 52 \\
\hline \multirow[t]{11}{*}{ Mustelidae } & Ictonyx & Ictonyx libyca & SEX+SSP & 36 \\
\hline & & Ictonyx striatus & SEX+SSP & 47 \\
\hline & & Poecilogale albinucha & $\varnothing$ & 33 \\
\hline & Lontra & Lontra canadensis & SSP & 46 \\
\hline & & Lontra longicaudis & SSP & 46 \\
\hline & Lutra & Lutra lutra & SEX+SSP & 37 \\
\hline & Martes & Martes americana & $\varnothing$ & 43 \\
\hline & & Martes flavigula & SEX & 44 \\
\hline & & Martes foina & SEX+SSP & 39 \\
\hline & & Martes pennanti & SEX+SSP & 34 \\
\hline & & Martes zibellina & $\varnothing$ & 40 \\
\hline
\end{tabular}

Continues on next page 
Table D.1 - continued from previous page

\begin{tabular}{|c|c|c|c|c|}
\hline Family & Genus & Species & Control & $\mathrm{n}$ \\
\hline & Melogale & Melogale moschata & $\varnothing$ & 46 \\
\hline & & Melogale personata & $\varnothing$ & 45 \\
\hline & Mustela & Mustela erminea & SEX & 49 \\
\hline & & Mustela frenata & SEX & 42 \\
\hline & & Mustela nigripes & SEX & 48 \\
\hline & & Mustela nivalis & SEX+SSP & 43 \\
\hline & & Mustela putorius & SEX+SSP & 39 \\
\hline & & Mustela sibirica & SSP+SEX & 39 \\
\hline & & Mustela vison & $\varnothing$ & 37 \\
\hline & Pteronura & Pteronura brasiliensis & $\varnothing$ & 35 \\
\hline & Taxidea & Taxidea taxus & SEX & 36 \\
\hline Nandiniidae & Nandinia & Nandinia binotata & $\mathrm{SEX}+\mathrm{AGE}+\mathrm{SSP}$ & 49 \\
\hline \multirow[t]{22}{*}{ Felidae } & Acinonyx & Acinonyx jubatus & $\mathrm{SEX}+\mathrm{SSP}+\mathrm{AGE}$ & 50 \\
\hline & Caracal & Caracal caracal & SEX+AGE & 50 \\
\hline & Catopuma & Catopuma temminckii & SEX+AGE & 40 \\
\hline & Felis & Felis catus & AGE & 29 \\
\hline & & Felis margarita & $\mathrm{AGE}+\mathrm{SEX}{ }^{*} \mathrm{CAT}$ & 49 \\
\hline & & Felis silvestris & $\mathrm{AGE}+\mathrm{SEX} * \mathrm{CAT}$ & 49 \\
\hline & Leopardus & Leopardus geoffroyi & SEX+SSP+CAT & 47 \\
\hline & & Leopardus guttulus & SEX & 43 \\
\hline & & Leopardus mitis & $\mathrm{SEX}+\mathrm{SSP}+\mathrm{AGE}$ & 73 \\
\hline & & Leopardus wiedii & SEX+SSP & 50 \\
\hline & Leptailurus & Leptailurus serval & $\mathrm{SEX} * \mathrm{SSP}+\mathrm{AGE}+\mathrm{CAP}$ & 51 \\
\hline & $\operatorname{Lyn} x$ & Lynx lynx & $\mathrm{SSP}+\mathrm{AGE}$ & 50 \\
\hline & & Lynx rufus & $\mathrm{SSP}+\mathrm{AGE}+\mathrm{SEX}$ & 46 \\
\hline & Neofelis & Neofelis diardi & $\mathrm{SEX}+\mathrm{AGE}+\mathrm{CAT}$ & 40 \\
\hline & Panthera & Panthera leo & $\mathrm{SEX}+\mathrm{SSP}+\mathrm{CAT}$ & 50 \\
\hline & & Panthera onca & $\mathrm{AGE}+\mathrm{SSP}+\mathrm{SEX}$ & 54 \\
\hline & & Panthera pardus & $\mathrm{SEX}+\mathrm{SSP}+\mathrm{AGE}$ & 52 \\
\hline & & Panthera tigris & $\mathrm{SEX}+\mathrm{AGE}+\mathrm{SSP}+\mathrm{CAT}$ & 48 \\
\hline & & Panthera uncia & $\mathrm{SEX}+\mathrm{SSP}+\mathrm{AGE}$ & 46 \\
\hline & Prionailurus & Prionailurus bengalensis & SSP & 50 \\
\hline & Puma & Puma concolor & $\mathrm{SSP}+\mathrm{AGE}+\mathrm{SEX}$ & 50 \\
\hline & & Puma yagouaroundi & SSP+SEX & 50 \\
\hline \multirow[t]{10}{*}{ Viverridae } & Arctictis & Arctictis binturong & $\mathrm{SSP}+\mathrm{AGE}$ & 50 \\
\hline & Arctogalidia & Arctogalidia stigmatica & SEX & 31 \\
\hline & Civettictis & Civettictis civetta & SEX $*$ SSP & 51 \\
\hline & Genetta & Genetta genetta & SSP*SEX & 57 \\
\hline & & Genetta maculata & $\mathrm{SSP}+\mathrm{SEX}+\mathrm{CAT}+\mathrm{AGE}$ & 59 \\
\hline & & Genetta servalina & SSP & 44 \\
\hline & Hemigalus & Hemigalus derbyanus & $\mathrm{SSP}+\mathrm{SEX}+\mathrm{AGE}$ & 34 \\
\hline & Paguma & Paguma larvata & $\mathrm{SSP}+\mathrm{CAT}$ & 50 \\
\hline & Paradoxurus & Paradoxurus musanga & $\mathrm{SSP}+\mathrm{AGE}$ & 50 \\
\hline & Viverra & Viverra zibetha & $\mathrm{SSP}+\mathrm{AGE}$ & 48 \\
\hline
\end{tabular}

Continues on next page 
Table D.1 - continued from previous page

\begin{tabular}{lllll}
\hline Family & Genus & Species & Control & $\mathrm{n}$ \\
\hline \multirow{6}{*}{ Hyaenidae } & Viverricula & Viverricula indica & SSP+AGE+SEX & 56 \\
& Crocuta & Crocuta crocuta & SEX*SSP+AGE & 50 \\
& Hyaena & Hyaena hyaena & AGE+CAT+SSP & 51 \\
& Parahyaena & Parahyaena brunnea & AGE+SSP+SEX & 49 \\
& Proteles & Proteles cristata & SSP+AGE & 44 \\
Herpestidae & Atilax & Atilax paludinosus & SEX+SSP & 50 \\
& Crossarchus & Crossarchus obscurus & $\varnothing$ & 31 \\
& & Crossarchus platycephalus & AGE+CAP & 39 \\
& Cynictis & Cynictis penicillata & SSP*CAP & 53 \\
& Galerella & Galerella sanguinea & SSP & 36 \\
& Helogale & Helogale parvula & SSP+AGE+CAP & 50 \\
& Mungos & Mungos mungo & SSP+AGE & 62 \\
& Suricata & Suricata suricatta & AGE+CAT & 51 \\
& Urva & Urva javanica & SEX+SSP & 50 \\
Eupleridae & Cryptoprocta & Crva urva & AGE+SEX+SSP & 44 \\
& Galidia & Galidia elegans & AGE+SEX*CAP & 34 \\
& & & SEX+AGE+SSP & 47 \\
\hline
\end{tabular}




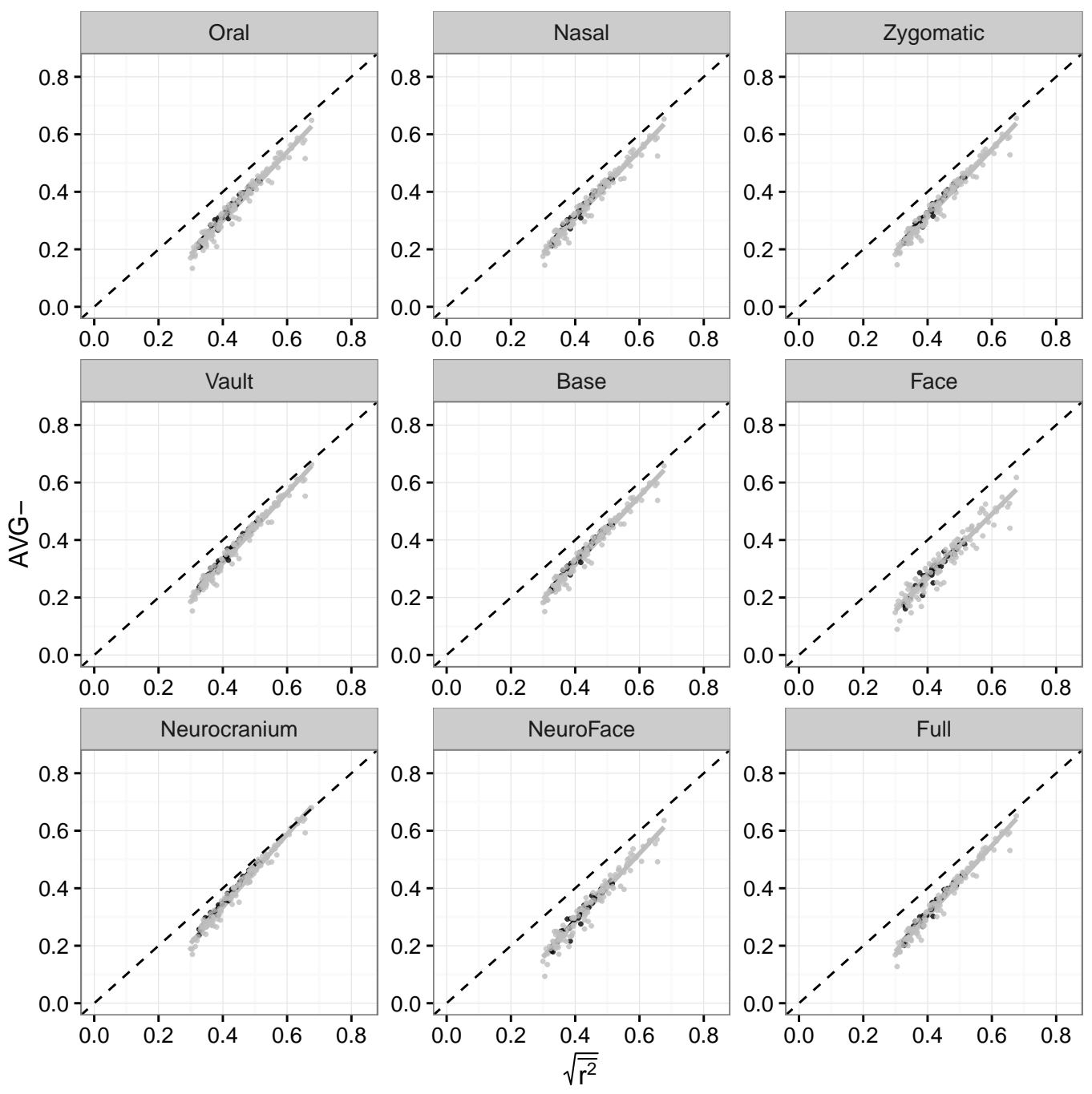

Figure D.1: Relationship between morphological integration index $\sqrt{\overline{r^{2}}}$ and AVG- for different modularity hypotheses. Black- Canidae. Gray- Noncanid Carnivora. Dashed line- AVG+=AVG-. 

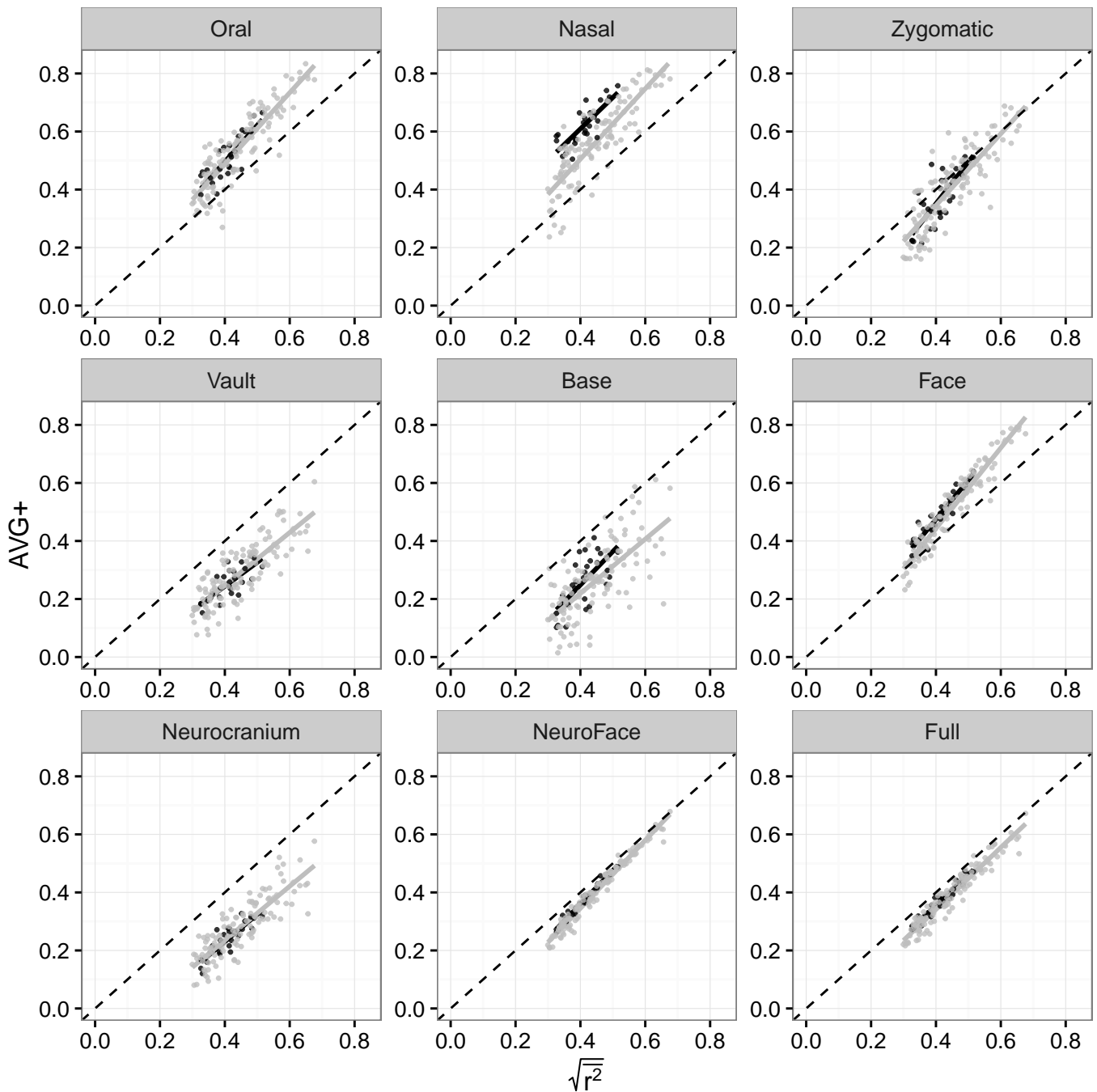

Figure D.2: Relationship between morphological integration index $\sqrt{\overline{r^{2}}}$ and AVG+ for different modularity hypotheses. Black- Canidae. Gray- Noncanid Carnivora. Dashed line- AVG+=AVG-. 

Appendix E

Apêndice do Capítulo 4 


\section{Phylogeny, Taxonomy and Sample Sizes}

Since there is no updated phylogeny including all species of Caniformes, we focused on the most complete dated phylogeny of the whole group (Slater et al., 2012). This phylogeny was modified according to new information, or information that was not included in that particular study. Bellow we provide a detailed description of the modifications done and the references that support them (when necessary).

- Canidae

- The position of P. vetulus was set as sister to P. culpaeus (Perini et al., 2010) to ensure monophiletism of the genus.

- V. chama and the clade formed by all other Vulpes with the exception of V. cana and V. zerda (Nyakatura and Bininda-Emonds, 2012).

- V. velox as set as sister to V. macrotis (Mercure et al., 1993).

- V. pallida as set as sister to V. corsac (Bininda-Emonds et al., 1999; Clark Jr et al., 2008).

- $V$. ferrilata as set as sister to the clade formed by $V$. corsac and $V$. pallida (Bininda-Emonds et al., 1999; Clark Jr et al., 2008).

- V. bengalensis as fixed in a polytomy along with $V$. chama and the clade formed by all other Vulpes with the exception of $V$. cana and V. zerda (Nyakatura and Bininda-Emonds, 2012).

- C. aureus label was substituted for C. anthus (Koepfli et al., 2015).

- C. aureus was set as sister to all other Canis with the exception of C. mesomelas, C. adustus, L. pictus and C. alpinus (Koepfli et al., 2015). 
- C. indica was set as sister to C. lupus and C. hymalayensis as set as sister to both (Koepfli et al., 2015).

- C. rufus was set as sister to C. latrans and C. lycaon as set as sister to both (Rutledge et al., 2012).

- Procyonidae

- P. pygmaeus was placed in a polytomy along with other Procyon (de Villa-Meza et al., 2011).

- Bassaricyon phylogeny was set according to Helgen et al. (2013).

- N. olivacea and N. meridensis were set as sister species associated with N. narica (Helgen et al., 2009).

- Mephitidae

- C. humboldtii was added as sister C. chinga and C. semistriatus was added as sister to both (Schiaffini et al., 2013).

- All Spilogale were set in a polytomy because lack of studies for these species.

- Phocidae

- Neomonachus was set as siter to both Monachus species (Scheel et al., 2014).

- Mustelidae

- M. canescens was set as sister of $M$. meles and both were set as sister to clade formed by M. anakuma and M. leucurus (Abramov and Puzachenko, 2013; İbiş et al., 2015).

- L. patagonicus was set as sister to Galictis (Sato et al., 2012). 
- All Melogale were set in a polytomy because lack of studies for these species.

- A. congicus was set as sister to the clade formed by other Aonyx and Lutrogale because there was no study detaling its placement.

- M. subpalmata was set as sister to M. nivalis (Nyakatura and BinindaEmonds, 2012).

- M. kathiah was set as sister to the clade including sister to M. nivalis (Sato et al., 2012).

- M. itatsi was set as sister to the clade including M. sibirica and $M$. eversmanni (Sato et al., 2012).

- M. felipei and M. africana were set as a clade sister to M. frenata (Arnold et al., 2010; Nyakatura and Bininda-Emonds, 2012).

- L. provocax was set as sister to L. felina (Arnold et al., 2010; Nyakatura and Bininda-Emonds, 2012).

- Arctonyx species were set on a polytomy (Helgen et al., 2008).

Taxonomic affinities within Carnivora are far from resolved, and nomenclature reassessments and new species descriptions are not infrequent, mainly due to the use of molecular techniques (e.g. Zrzavy and Ricankova, 2004; Bardeleben et al., 2005; Helgen et al., 2008, 2013; Bornholdt et al., 2013; Prevosti et al., 2013; Schiaffini et al., 2013). Explicit subspecies validations are rare for fissipeds (but see Berta and Churchill, 2012), interfering with the swift allocation of specimens based on geographic data (essential for controling for effects on $\mathbf{W}$ matrix estimation, see Chapter D). Consequently, taxonomic guides such as Nowak (1999) and Wilson and Reeder (2005) were found to be lacking for particularly problematic taxa, given that they predate newer taxonomic works for those groups. For these reasons, taxonomic decisions were drawn from numerous sources, mainly Mammalian Species 
reports (see References for full list) and the previously mentioned works. The only exception was the taxonomy of pinnipeds, which followed Berta and Churchill (2012). The resulting taxonomy can be found on Table E.1 along with the sample-size for each species.

Table E.1: Taxonomy and sample sizes

\begin{tabular}{clll} 
Family & Genus & Species & $\mathrm{n}$ \\
\hline Canidae & Atelocynus & Atelocynus microtis & 23 \\
& Canis & 38 \\
& Canis adustus anthus & 54 \\
& Canis aureus & 27 \\
& Canis himalayensis & 10 \\
& Canis indica & 6 \\
& Canis latrans & 61 \\
& Canis lupus & 107 \\
& Canis lycaon & 48 \\
& Canis mesomelas & 57 \\
& Canis rufus & 46 \\
& Canis simensis & 10 \\
& Cuon alpinus & 21 \\
& Lycaon pictus & 45 \\
Cerdocyon & Cerdocyon thous & 77 \\
Lycalopex & Chrysocyon brachyurus & 57 \\
& Lycalopex culpaeus & 44 \\
& Lycalopex fulvipes & 2 \\
& Lycalopex griseus & 39 \\
& Lycalopex gymnocercus & 45 \\
& Lycalopex sechurae & 37 \\
& Lycalopex vetulus & 39 \\
& Nyctereutes procyonoides & 41 \\
Nyctereutes & 51 \\
Otocyon & Otocyon megalotis & 56 \\
Speothos & Speothos venaticus & 44 \\
Urocyon & Urocyon cinereoargenteus & 44 \\
& Urocyon littoralis & 54 \\
Vulpes & Vulpes bengalensis & 10 \\
& Vulpes chama & 26 \\
& Vulpes corsac & 3 \\
& Vulpes ferrilata & 4 \\
& Vulpes lagopus & 52 \\
& Vulpes macrotis & 48 \\
& Vulpes pallida & 17 \\
& Vulpes rueppellii & 58 \\
\hline & & \\
& &
\end{tabular}

Continues on next page 
Table E.1 - continued from previous page

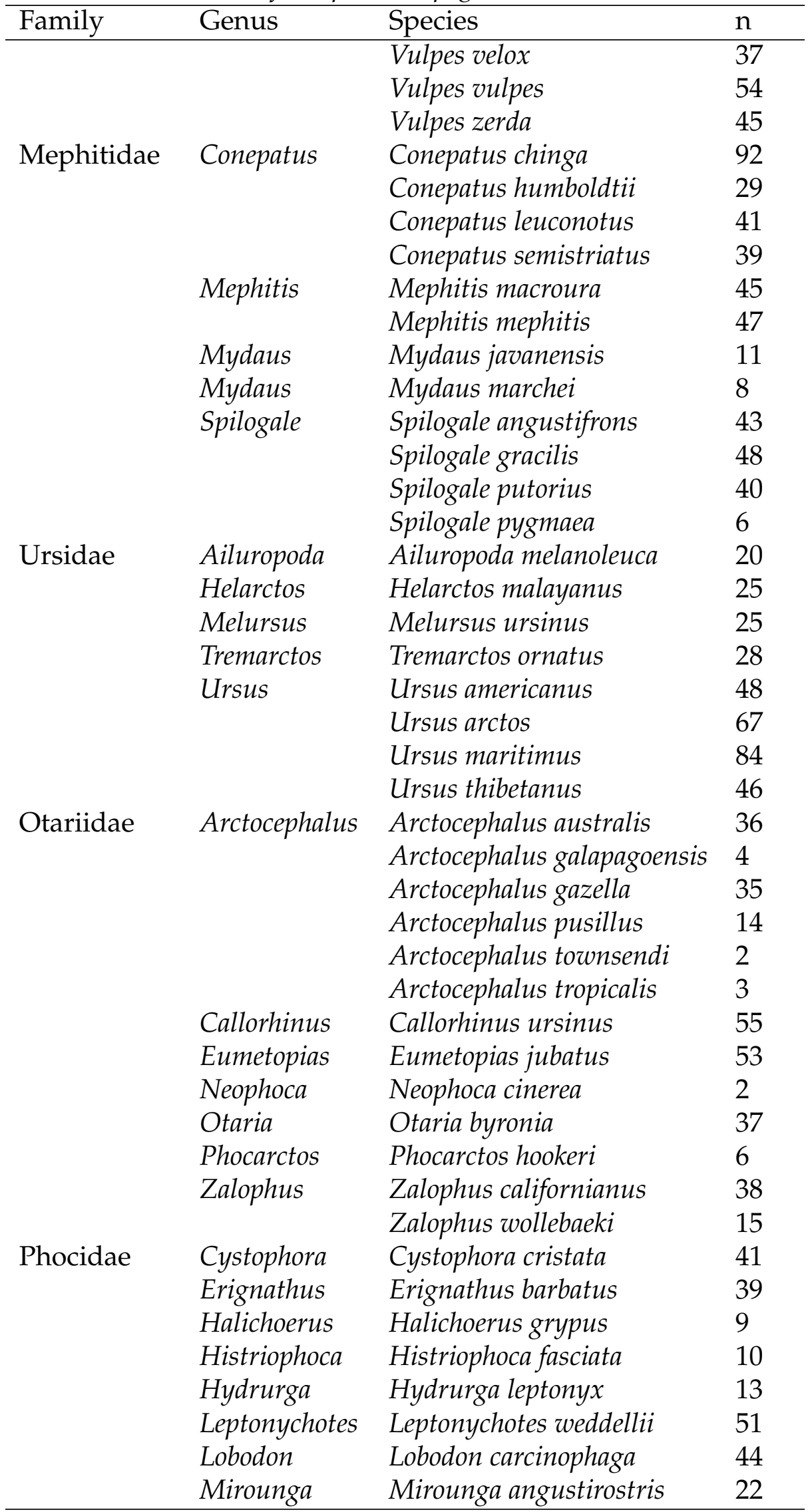

Continues on next page 
Table E.1 - continued from previous page

\begin{tabular}{|c|c|c|c|}
\hline Family & Genus & Species & $\mathrm{n}$ \\
\hline & & Mirounga leonina & 33 \\
\hline & Monachus & Monachus monachus & 2 \\
\hline & Neomonachus & Neomonachus schauinslandi & 19 \\
\hline & & Neomonachus tropicalis & 37 \\
\hline & Ommatophoca & Ommatophoca rossii & 7 \\
\hline & Pagophilus & Pagophilus groenlandicus & 47 \\
\hline & Pusa & Pusa caspica & 2 \\
\hline & & Pusa hispida & 51 \\
\hline & & Pusa sibirica & 9 \\
\hline & Phoca & Phoca largha & 6 \\
\hline & & Phoca vitulina & 53 \\
\hline & & Phoca vitulina & 53 \\
\hline \multirow[t]{14}{*}{ Procyonidae } & Bassaricyon & Bassaricyon alleni & 30 \\
\hline & & Bassaricyon gabbii & 9 \\
\hline & & Bassaricyon medius & 40 \\
\hline & & Bassaricyon neblina & 8 \\
\hline & Bassariscus & Bassariscus astutus & 46 \\
\hline & & Bassariscus sumichrasti & 45 \\
\hline & Nasua & Nasua narica & 44 \\
\hline & & Nasua nasua & 60 \\
\hline & & Nasuella meridensis & 2 \\
\hline & & Nasuella olivacea & 17 \\
\hline & Potos & Potos flavus & 63 \\
\hline & Procyon & Procyon cancrivorus & 41 \\
\hline & & Procyon lotor & 52 \\
\hline & & Procyon pygmaeus & 3 \\
\hline \multirow[t]{18}{*}{ Mustelidae } & Aonyx & Aonyx capensis & 2 \\
\hline & & Aonyx cinerea & 24 \\
\hline & & Aonyx congicus & 2 \\
\hline & Arctonyx & Arctonyx albogularis & 16 \\
\hline & & Arctonyx collaris & 12 \\
\hline & & Arctonyx hoevenii & 2 \\
\hline & Eira & Eira barbara & 77 \\
\hline & Enhydra & Enhydra lutris & 43 \\
\hline & Galictis & Galictis cuja & 45 \\
\hline & & Galictis vittata & 34 \\
\hline & Gulo & Gulo gulo & 52 \\
\hline & Hydrictis & Hydrictis maculicollis & 11 \\
\hline & Ictonyx & Ictonyx libyca & 36 \\
\hline & & Ictonyx striatus & 47 \\
\hline & Lontra & Lontra canadensis & 46 \\
\hline & & Lontra felina & 11 \\
\hline & & Lontra longicaudis & 46 \\
\hline & & Lontra provocax & 2 \\
\hline
\end{tabular}

Continues on next page 
Table E.1 - continued from previous page

\begin{tabular}{|c|c|c|c|}
\hline Family & Genus & Species & $\mathrm{n}$ \\
\hline & Lutra & Lutra lutra & 37 \\
\hline & & Lutra sumatrana & 5 \\
\hline & Lutrogale & Lutrogale perspicillata & 4 \\
\hline & Lyncodon & Lyncodon patagonicus & 6 \\
\hline & Martes & Martes americana & 43 \\
\hline & & Martes flavigula & 44 \\
\hline & & Martes foina & 39 \\
\hline & & Martes martes & 9 \\
\hline & & Martes melampus & 5 \\
\hline & & Martes pennanti & 34 \\
\hline & & Martes zibellina & 40 \\
\hline & Meles & Meles anakuma & 2 \\
\hline & & Meles leucurus & 10 \\
\hline & & Meles meles & 25 \\
\hline & & Meles canescens & 11 \\
\hline & Mellivora & Mellivora capensis & 22 \\
\hline & & Melogale everetti & 15 \\
\hline & & Melogale moschata & 46 \\
\hline & & Melogale orientalis & 14 \\
\hline & & Melogale personata & 45 \\
\hline & Mustela & Mustela africana & 13 \\
\hline & & Mustela altaica & 25 \\
\hline & & Mustela erminea & 49 \\
\hline & & Mustela eversmanni & 14 \\
\hline & & Mustela felipei & 2 \\
\hline & & Mustela frenata & 42 \\
\hline & & Mustela itatsi & 25 \\
\hline & & Mustela kathiah & 22 \\
\hline & & Mustela lutreola & 2 \\
\hline & & Mustela nigripes & 48 \\
\hline & & Mustela nivalis & 43 \\
\hline & & Mustela nudipes & 9 \\
\hline & & Mustela putorius & 39 \\
\hline & & Mustela sibirica & 39 \\
\hline & & Mustela subpalmata & 10 \\
\hline & & Mustela vison & 37 \\
\hline & Poecilogale & Poecilogale albinucha & 33 \\
\hline & Pteronura & Pteronura brasiliensis & 35 \\
\hline & Taxidea & Taxidea taxus & 36 \\
\hline & Vormela & Vormela peregusna & 8 \\
\hline & & Total & 5088 \\
\hline
\end{tabular}




\section{Tree transformation}

Differences in three shape might influence the performance of tests because of two main reasons: firstly, if phylogenetic dependence introduces correlation among traits, then transforming a tree into a "star-like" phylogeny (no dependence between taxa) would improve type I error rates and power for the analysis of the raw data. Secondly, since different tree shapes are expected under different diversification scenarios, we can investigate the performance of the tests under different situations.

Here we chose to transform the tree according to an "Early-Burst" (EB) model

$$
r(t)=r(0) \exp (a t)
$$

were $a$ is the rate change parameter and $\mathrm{r}(0)$ and $\mathrm{r}(\mathrm{t})$ are rates of diversification at time 0 and $\mathrm{t}$, respectively. $a$ was modeled as varying from -1 to 2 (31 values), with lower values producing a more "tip-heavy" tree (more diversification at the tips) and higher values producing a more "star-like" phylogeny (more diversification at the base).

We used the EB model because it manipulates the rates of speciation events through time and is not necessarily associated to the mode of phenotypic evolution, such as Ornstein-Uhlenbeck or Pagel- $\lambda$ transformations. This transformation was applied to the full tree and investigations of different values of $a$ were conducted on the full sample only. Power was investigated only for $e=1$.

Figure E.1 shows the effects of applying an "Early Burst" transformation on both type I error rates and power. Type I error rates for the full sample (all Caniformes) are largely unaffected by the transformation of the tree according to an "Early Burst" model, with the exception that, as the values of 
parameter $a$ increases (producing a more "star-like" phylogeny Figure E.1B), than the error rates for the correlation analysis on raw data approaches the nominal value (alpha $=0.05$ ). The only test that had its power affected due to tree transformation was the regression analysis, that showed a decrease in power for lower values of $e$ (producing a more "tip-heavy" phylogeny Figure E.1A). 

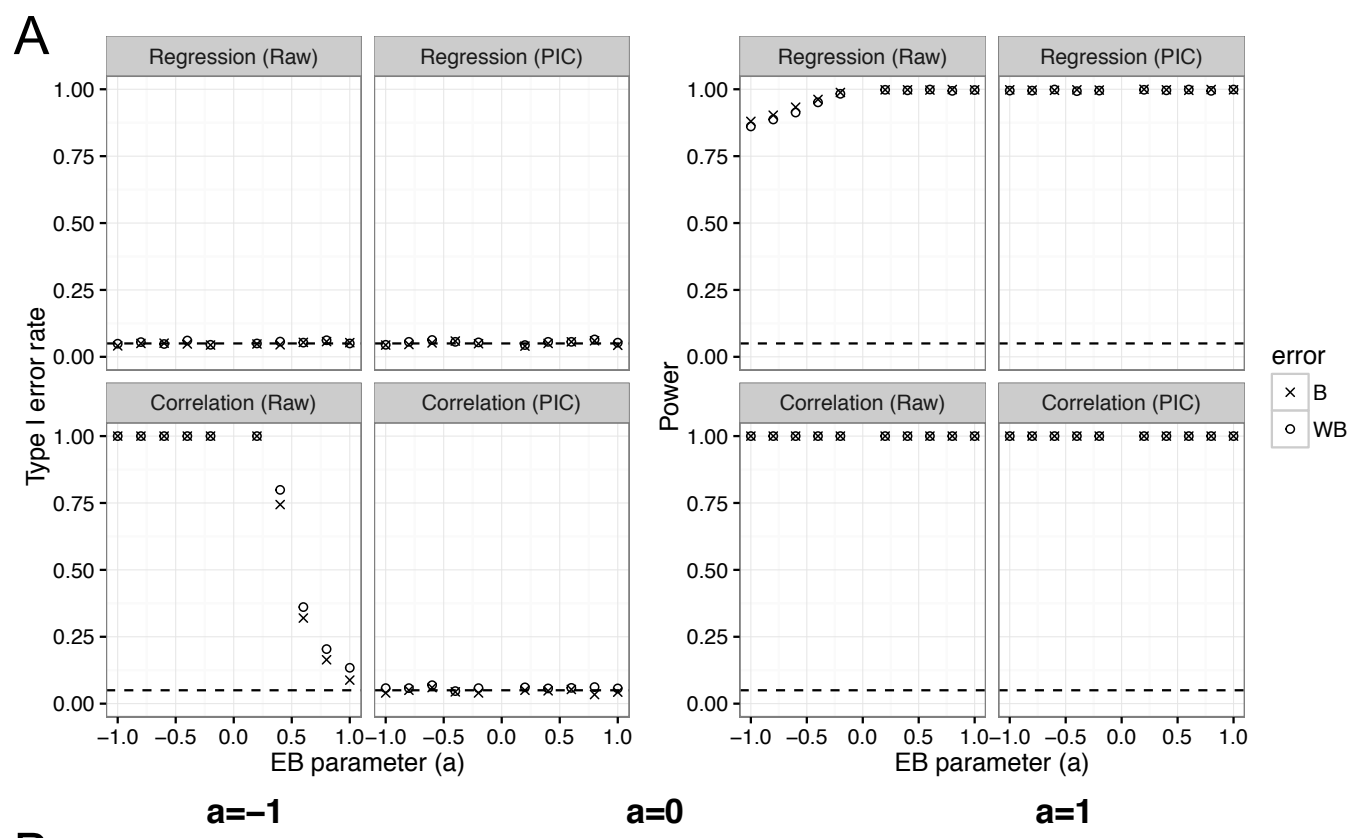

B

$a=-1$

$a=0$
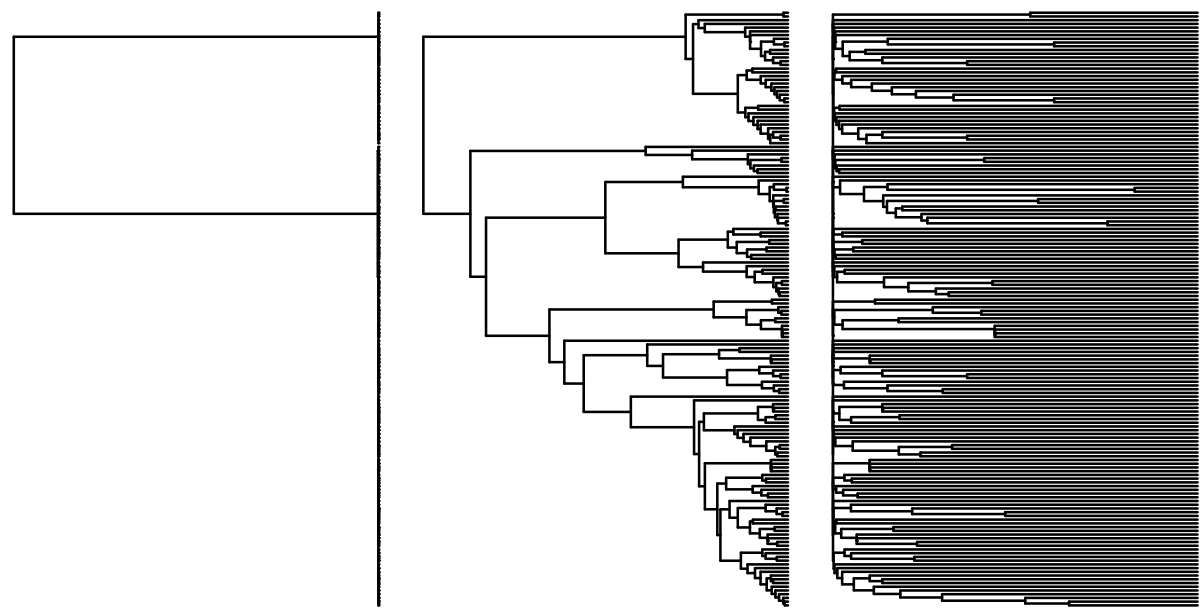

Figure E.1: A- Type I and power for different values for $a$ (Early Burst parameter). Power was accessed for $e=1000$. B- Transformations applied to Caniform phylogeny to investigate effect of tree shape on the quantitative genetics tests of neutral evolution. 


\section{Simulations}

The code used for the simulations can be seen bellow. Number between brackets in the bellow description refers to specific lines on the R code.

Simulations were carried out using the sim.corrs function from the $\mathrm{R}$ package (Revell, 2012) [27 - 28]. This function models the evolution along a tree as a phylogenetically structured random walk on the space defined by a given covariance matrix $\mathbf{D}$. This is done by sampling a normal distribution $n p$ times, were $\mathrm{n}$ is the number of transitions (ancestral-descendent pairs) on a tree and $\mathrm{p}$ is the number of traits. Each draw is assigned to a transition and is multiplied by its branch length. The resulting data is then multiplied by the Cholesky factor of $\mathbf{D}$, and the transitions are then summed up from the base to the tips of the phylogeny in order to produce average values for the species.

D was modeled through Equation (4.5) using the pooled within-covariance matrix $\mathbf{P}$ as a surrogate for $\mathbf{G}$ and a randomly produced $\mathbf{C}$ [10 - 13]. Given that we initially want selection and drift to have the same relative importance when the effect size $e=1$, all branch lengths of the phylogeny were set to be proportional to $\frac{t}{N_{e}}[5,24-25]$. This gives us branch lengths proportional to the amount of divergence expected due to drift (Felsenstein, 1988). Thus, for $e=1$, then we can rewrite Equation (4.5) as

$$
\mathbf{B}=b_{l}(\mathbf{A}+\mathbf{G})
$$

were $b_{l}$ is the scaled branch lengths. So according to the above equation, for each generation both selection and drift will have an equal trace of $1 / N_{e}$. This do not mean that selection will depend on $N_{e}$, but it establishes a baseline where both selection and drift contribute equally (i.e they have to be scaled by the same factor). 
Given that phenotypic evolution is modeled by the sum of the selection and drift [27 - 30], we can simulate both components independently as

$$
\begin{gathered}
\mathbf{B}=\mathbf{B}_{\text {drift }}+\mathbf{B}_{\text {selection }} \\
\mathbf{B}_{\text {drift }}=b_{l} \mathbf{G} \\
\mathbf{B}_{\text {selection }}=b_{l} e \mathbf{A}
\end{gathered}
$$

To ensure that the simulated data had the same rate of evolution as the observed data, we obtained the observed and the simulated $\operatorname{tr}\left(\mathbf{B}_{\text {PIC }}\right)$. The square-root of the ratio between both is a scaling factor that, if applied to the simulated data, ensures that $\operatorname{tr}\left(\mathbf{B}_{\text {PIC }}\right)$ of both will be equal [31-33]. Since the final data will be re-scaled, then the actual scale of the simulated data can be arbitrary. For this reason, both the traces of G, and GCG were set to 1 to facilitate the calculations $[9,13-14]$.

After simulating the evolution of species means we then drew from $\mathbf{P}$ a sample equal to the sample size of each species, with means equal to a vector of 0 s [35]. The resulting data was then average and added to each species means in order to simulate sampling error on species averages [3639]. Additionally, to account for sampling error on this matrix, the simulated intraspecific data was retained and used to re-estimate $\mathbf{W}$ [35]. Since both original $\mathbf{W}$ and simulated within-group data were stored, both original $\mathbf{W}$ and re-sampled $\mathbf{W}$ can be used on the calculations to evaluate impact of sampling error. Table E.2 summarizes the total number of simulations per analysis. 
Table E.2: Summary of the number of simulations per analysis. $N_{e^{-}}$number of different effective population sizes; $e$ - number of different effect size of directional selection; $a$ - number of different Early-Burst parameter used; Clades- number of clades used; PCs- number of different amounts of PCs reteined, Runs- number of runs performed for each case. See text for the description of each analysis.

\begin{tabular}{lccccccc}
\hline tests & $N_{e}$ & $\mathrm{e}$ & $\mathrm{a}$ & Clades & PCs & runs & Total \\
\hline Error rates & 1 & 8 & 1 & 91 & 1 & 1000 & $7.28 \mathrm{E}+05$ \\
Tree transformation & 1 & 2 & 10 & 1 & 1 & 1000 & $2.00 \mathrm{E}+04$ \\
Oscillations in $N_{e}$ & 5 & 1 & 1 & 91 & 1 & 1000 & $4.55 \mathrm{E}+05$ \\
Dimension reduction & 1 & 8 & 1 & 18 & 6 & 1000 & $8.64 \mathrm{E}+05$ \\
& & & & & & total $=$ & $2.07 \mathrm{E}+06$ \\
\hline
\end{tabular}

\section{$\mathbf{R}$ code}

\section{Simulation of multivariate phenotypic evolution with drift and selection}

\section{Description}

Simulates multivariate phenotypic evolution along a phylogenetic tree. Simulations can be performed with both drift or drift plus directional selection with varying intensity.

\section{Usage}

1 sim_phylo(G, means, phy, n.s, inter $=1000$, parallel=FALSE,

$$
\begin{aligned}
& \hookrightarrow \text { selection }=1, \text { efsize }=0, \text { gen_time }=1 e-06, \text { Nef }=1000, N_{-} \\
& \hookrightarrow \text { osc }=\text { "no" ,Nef_par=NULL) }
\end{aligned}
$$

\section{Arguments}

G Genetic covariance matrix

means Dataframe of species average phenotipic values. Data should be arranged as speciesXcharacters with lines named after species.

phy Phylogenetic tree used on the simulation. Tip labels should correspond to rownames on means. 
n.s Vector containing sample size for each species on the same order as in means.

inter Number of iterations to be performed.

parallel Logical. If simulations are going to be performed in parallel. Uses package doParallel.

selection Numeric. Number of random vectors to be used as vectors of directional selection.

efsize Numeric. Effect size. If $=1$, then both selection and drift have similar magnitudes.

gen_time Numeric. Generation time in the scale of the tree. For million years $1 e 06=1$ year .

Nef Numeric or vector. Effective sample size $\left(N_{e}\right)$ for the population. If numeric, than the same $N_{e}$ is fixed throughout the tree. If a vector, should be the estimate $N_{e}$ for each node of the tree.

Nef_osc Character. If $N_{e}$ should be variable. Default "no". If "norm", than oscilations of $N_{e}$ are exponentials of values drawn from a normal distribution. If "unif", than values of $N_{e}$ are drawn from a uniform distribution.

Nef_par Numeric of vector. Default NULL. If Nef_osc="norm" than a numeric value for the sd of the distribution should be provided. If Nef_osc="unif" than a vector of length 2 should be provided giving lower and upper bounds of $N_{e}$. Unused if if Nef_osc="no". 


\section{Values}

sims List of outputs of each simulation of length inter. Each entry is a list containing the simulated averages (data.s), the resampled within-group distribution (ws), the simulated random vectors of selection (svec), the ratio between the empirical rate of evolution and the simulated one (rate.ratio) and the GCG matrix (A).

vcv The input covariance matrix $G$.

phy The input phylogeny phy.

n The number of species.

n.s The input sample size for each species n.s.

pics The phylogenetic independent contrasts for the observed data.

means The input matrix of species averages means.

1 sim_phylo<-function (G, means, phy, n.s, inter $=1000$, parallel= $\hookrightarrow$ FALSE, selection $=1$, efsize $=0$, gen_time $=1$ e -06, Nef $=1000$, $\hookrightarrow \quad$ Nef_osc="no",Nef_par=NULL $)\{$

$2 \quad \mathrm{vCV}<-\mathrm{G}$

$3 \operatorname{pics}<-$ apply(means, 2, function $(x)$ pic $(x$, phy $))$

4 rate $<-\operatorname{tr}(\operatorname{var}($ pics $))$

5 phy\$edge.length <- phy\$edge.length / gen_time

6 n<-length (phy\$tip. label)

7

8 bm.sim $<-$ function $(\mathrm{z})$ \{

$9 \quad \mathrm{G}<-\mathrm{G} / \operatorname{tr}(\mathrm{G})$

$10 \quad$ svec $<-$ NULL

11 svec $<-\operatorname{matrix}(\operatorname{Normalize}(\operatorname{rnorm}(\operatorname{dim}(G)[1] *$ selection $))$,

$\hookrightarrow \operatorname{dim}(\mathrm{G})[1]$, selection ) 
C $<-$ svec $\% * \%$ t $($ svec $)+\operatorname{diag}(35) * 0.0001$

$$
\text { if }(\text { Nef_osc }==" \text { no" }) \quad \text { Nef_osc }<- \text { Nef else }\{
$$$$
\text { if }(\text { Nef_osc }==" \text { norm" }) \text { Nef_osc }<- \text { Nef } * \exp (\text { rnorm }(\text { length }(
$$$$
\hookrightarrow \text { phy\$edge.length), Nef_par)) else \{ }
$$

if (Nef_osc==" unif") Nef_osc <- runif (length (phy\$edge

$$
\hookrightarrow \text {. length }), \min =\text { Nef_par[1], } \max =\text { Nef_par[2]) }
$$

phy1 <- phy

$$
\hookrightarrow \quad)) \text { ) }
$$

$$
\begin{aligned}
& \mathrm{s} \quad<- \text { sqrt }(\text { rate/rate.s) } \\
& \text { data.s }<- \text { data.s } * \mathrm{~s}
\end{aligned}
$$

$35 \quad$ ws<-rmvnorm $(\operatorname{sum}(n . s), \operatorname{sigma}=v c v)$

6 sps $<-$ rep (rownames (data.s), times $=$ n.s $)$

38

$$
\text { group_by }(., \text { sps ) } \% \% \text { summarize_each (funs (mean)) }
$$


39 data. $s<-$ data. $s+$ de $[,-1]$

40 list (data.s=data.s, ws=ws, svec=svec, rate.ratio=s^2, $A=$ $\hookrightarrow \mathrm{A}, \mathrm{svec}=$ svec $)$

$41\}$

42 data.s<-alply (1:inter, 1, bm.sim, $\cdot$ parallel = parallel $)$

$43 \quad$ ist $(\operatorname{sims}=$ data.s, $v c v=v c v, p h y=p h y, n=n, n . s=n . s, p i c s=p i c s$,

$\hookrightarrow$ means=means )

$44 \quad\}$ 


\section{References}

Abramov, A. V. and Puzachenko, A. Y. (2013). The taxonomic status of badgers (Mammalia, Mustelidae) from Southwest Asia based on cranial morphometrics, with the redescription of Meles canescens. Zootaxa, 3681(1):4416.

Adam, P. J. (2004). Monachus tropicalis. Mammalian Species, 747:1-9.

Adam, P. J. (2005). Lobodon carcinophaga. Mammalian Species, 772:1-14.

Arnold, C., Matthews, L. J., and Nunn, C. L. (2010). The 10kTrees website: A new online resource for primate phylogeny. Evolutionary Anthropology, 19(3):114-118.

Audet, A., Robbins, C., and Larivière, S. (2002). Alopex lagopus. Mammalian Species, 713:1-10.

Bardeleben, C., Moore, R. L., and Wayne, R. K. (2005). A molecular phylogeny of the Canidae based on six nuclear loci. Molecular Phylogenetics and Evolution, 37(3):815-831.

Beisiegel, B. d. M. and Zuercher, G. (2005). Speothos venaticus. Mammalian Species, 783:1-6.

Bekoff, M. (1977). Canis latrans. Mammalian Species, 79:1-9.

Berta, A. (1982). Cerdocyon thous. Mammalian Species, 186:1-4.

Berta, A. (1986). Atelocynus microtis. Mammalian Species, 256:1-3.

Berta, A. and Churchill, M. (2012). Pinniped taxonomy: review of currently recognized species and subspecies, and evidence used for their description. Mammal Review, 42:207-234.

Bininda-Emonds, O., Gittleman, J. L., and Purvis, A. (1999). Building large trees by combining phylogenetic information: a complete phylogeny of the extant Carnivora (Mammalia). Biological Reviews, 74.

Bornholdt, R., Helgen, K. M., Koepfli, K.-P., Oliveira, L. R., Lucherini, M., and Eizirik, E. (2013). Taxonomic revision of the genus Galictis (Carnivora: Mustelidae): species delimitation, morphological diagnosis, and refined mapping of geographical distribution. Zoological Journal of the Linnean Society, 167(3):449-472.

Chaves, H. E. R. and Patterson, B. D. (2014). Mustela felipei (Carnivora: Mustelidae). Mammalian Species, 46(906):11-15.

Clark, T. W. (1975). Arctocephalus galapagoensis. Mammalian Species, 64:1-2.

Clark Jr, H. (2005). Otocyon megalotis. Mammalian Species, 766:1-5. 
Clark Jr, H. O., Murdoch, J. D., Newman, D. P., and Sillero-Zubiri, C. (2009). Vulpes corsac (Carnivora: Canidae). Mammalian Species, 831:1-8.

Clark Jr, H. O., Newman, D. P., Murdoch, J. D., Tseng, J., Wang, Z. H., and Harris, R. B. (2008). Vulpes ferrilata (Carnivora: Canidae). Mammalian Species, 821:1-6.

Cohen, J. (1978). Cuon alpinus. Mammalian Species, 100:1-3.

Cossíos, E. D. (2010). Lycalopex sechurae (Carnivora: Canidae). Mammalian Species, 42:1-6.

Dalponte, J. C. (2009). Lycalopex vetulus (Carnivora: Canidae). Mammalian Species, 847:1-7.

de Villa-Meza, A., Avila-Flores, R., Cuarón, A. D., and Valenzuela-Galván, D. (2011). Procyon pygmaeus (Carnivora: Procyonidae). Mammalian Species, 43(1):87-93.

DeMaster, D. P. and Stirling, I. (1981). Ursus maritimus. Mammalian Species, 145:1-7.

Dietz, J. M. (1985). Chrysocyon brachyurus. Mammalian Species, 234:1-4.

Dragoo, J. W. and Sheffield, S. R. (2009). Conepatus leuconotus (Carnivora: Mephitidae). Mammalian Species, 827:1-8.

Egoscue, H. (1979). Vulpes velox. Mammalian Species, 122:1-5.

Estes, J. (2001). Enhydra lutris. Mammalian Species, 133:1-8.

Felsenstein, J. (1988). Phylogenies and quantitative characters. Annual Review of Ecology and Systematics, 19:445-471.

Fitzgerald, C. S. and Krausman, P. R. (2002). Helarctos malayanus. Mammalian Species, 696:1-5.

Ford, L. S. and Hoffmann, R. S. (1988). Potos flavus. Mammalian Species, 321:1-9.

Fritzell, E. and Haroldson, K. (1982). Urocyon cinereoargenteus. Mammalian Species, 189:1-8.

Geffen, E. (1994). Vulpes cana. Mammalian Species, 462:1-4.

Gompper, M. E. (1995). Nasua narica. Mammalian Species, 487:1-10.

Gompper, M. E. and Vanak, A. T. (2006). Vulpes bengalensis. Mammalian Species, 795:1-5.

Gorsuch, W. A. and Larivière, S. (2005). Vormela peregusna. Mammalian Species, 779:1-5. 
Helgen, K. M., Kays, R., and Helgen, L. (2009). Taxonomic boundaries and geographic distributions revealed by an integrative systematic overview of the mountain coatis, Nasuella (Carnivora: Procyonidae). Small Carnivore Conservation, 41:65-74.

Helgen, K. M., Lim, N. T.-L., and Helgen, L. (2008). The hog-badger is not an edentate: systematics and evolution of the genus Arctonyx (Mammalia: Mustelidae). Zoological Journal of the Linnean Society, 154:353-385.

Helgen, K. M., Pinto, M., Kays, R., Helgen, L., Tsuchiya, M., Quinn, A., Wilson, D., and Maldonado, J. (2013). Taxonomic revision of the olingos (Bassaricyon), with description of a new species, the Olinguito. ZooKeys, 324:183.

Hillman, C. N. and Clark, T. W. (1980). Mustela nigripes. Mammalian Species, 126:1-3.

Hwang, Y. T. and Larivière, S. (2003). Mydaus javanensis. Mammalian Species, 723:1-3.

İbiş, O., Tez, C., Özcan, S., Yorulmaz, T., and Mohradi, A. K. M. (2015). Insights into the Turkish and Iranian badgers (the genus Meles) based on the mitochondrial cyto-chrome b gene sequences. Vertebrate Zoology, 65(3):399-407.

Koepfli, K.-P., Pollinger, J., Godinho, R., Robinson, J., Lea, A., Hendricks, S., Schweizer, R. M., Thalmann, O., Silva, P., Fan, Z., Yurchenko, A. A., Dobrynin, P., Makunin, A., Cahill, J. A., Shapiro, B., Álvares, F., Brito, J. C., Geffen, E., Leonard, J. A., Helgen, K. M., Johnson, W. E., OBrien, S. J., Van Valkenburgh, B., and Wayne, R. K. (2015). Genome-wide Evidence Reveals that African and Eurasian Golden Jackals Are Distinct Species. Current biology : CB, 25(16):2158-2165.

Kovacs, K. M. and Lavigne, D. M. (1986). Cystophora cristata. Mammalian Species, 258:1-9.

Larivière, S. (1998). Lontra felina. Mammalian Species, 575:1-5.

Larivière, S. (1999a). Lontra longicaudis. Mammalian Species, 609:1-5.

Larivière, S. (1999b). Mustela vision. Mammalian Species, 608:1-9.

Larivière, S. (2001a). Aonyx capensis. 650:1-3.

Larivière, S. (2001b). Lontra provocax. Mammalian Species, 610:1-4.

Larivière, S. (2001c). Poecilogale albinucha. Mammalian Species, 681:1-4.

Larivière, S. (2001d). Ursus americanus. Mammalian Species, 647:1-11.

Larivière, S. (2002a). Ictonyx striatus. Mammalian Species, 698:1-5. 
Larivière, S. (2002b). Lutra maculicollis. Mammalian Species, 712:1-6.

Larivière, S. (2002c). Vulpes zerda. Mammalian Species, 714:1-5.

Larivière, S. and Pasitschniak-Arts, M. (1996). Vulpes vulpes. Mammalian Species, 537:1-11.

Larivière, S. and Seddon, P. (2001). Vulpes rueppelli. Mammalian Species, 678:1-5.

Larivière, S. and Walton, L. (1998). Lontra canadensis. Mammalian Species, 587:1-8.

Ling, J. K. (1992). Neophoca cinerea. Mammalian Species, 31(2):1-7.

Ling, J. K. and Bryden, M. M. (1992). Mirounga leonina. Mammalian Species, 391:1-8.

Long, C. A. (1973). Taxidea taxus. Mammalian Species, 26:1-4.

Lotze, J. H. and Anderson, S. (1979). Procyon lotor. Mammalian Species, 119:18.

Lucherini, M. and Luengos Vidal, E. M. (2008). Lycalopex gymnocercus (Carnivora: Canidae). Mammalian Species, 820:1-9.

McGrew, J. (1979). Vulpes macrotis. Mammalian Species, 123:1-6.

Mech, L. D. (1974). Canis lupus. Mammalian Species, 37:1-6.

Medellín, R. A., Ceballos, G., and Zarza, H. (1998). Spilogale pygmaea. pages $1-3$.

Mercure, A., Ralls, K., Koepfli, K. P., and Wayne, R. K. (1993). Genetic subdivisions among small canids: mitochondrial DNA differentiation of swift, kit, and arctic foxes. Evolution, 47(5):1313.

Monakhov, V. G. (2011). Martes zibellina (Carnivora: Mustelidae). Mammalian Species, 43:75-86.

Moore, C. and Collins, P. (1995). Urocyon littoralis. Mammalian Species, 489:17.

Novaro, A. J. (1997). Pseudalopex culpaeus. Mammalian Species, 558:8.

Nowak, R. M. (1999). Walker's Mammals of the World, volume 1. JHU Press.

Nyakatura, K. and Bininda-Emonds, O. R. P. (2012). Updating the evolutionary history of Carnivora (Mammalia): a new species-level supertree complete with divergence time estimates. BMC Biology, 10(12):1-31.

Paradiso, J. and Nowak, R. (1972). Canis rufus. Mammalian Species, 22:1-4. 
Pasitschniak-Arts, M. (1993). Ursus arctos. Mammalian Species, 439:1-10.

Pasitschniak-Arts, M. and Larivière, S. (1995). Gulo gulo. Mammalian Species, 499:1-10.

Perini, F., Russo, C. A., and Schrago, C. (2010). The evolution of South American endemic canids: a history of rapid diversification and morphological parallelism. Journal of Evolutionary Biology, 23(2):311-322.

Poglayen-Neuwall, I. and Toweill, D. E. (1988). Bassariscus astutus. Mammalian Species, pages 1-8.

Prange, S. and Prange, T. J. (2009). Bassaricyon gabbii (Carnivora: Procyonidae). Mammalian Species, 826:1-7.

Prevosti, F. J., Segura, V., and Cassini, G. H. (2013). Revision of the systematic status of patagonian and pampean gray foxes (canidae: lycalopex griseus and 1. gymnocercus) using $3 \mathrm{~d}$ geometric morphometrics. Mastozoología Neotropical.

Ramírez-Chaves, H. E., Arango-Guerra, H. L., and Patterson, B. D. (2014). Mustela africana (Carnivora: Mustelidae). Mammalian Species, 917:110-115.

Revell, L. J. (2012). phytools: an R package for phylogenetic comparative biology (and other things). Methods in Ecology and Evolution, 3(2):217-223.

Rutledge, L. Y., Wilson, P. J., Klütsch, C. F. C., Patterson, B. R., and White, B. N. (2012). Conservation genomics in perspective: A holistic approach to understanding Canis evolution in North America. Biological Conservation, 155(C):186-192.

Sato, J. J., Wolsan, M., Prevosti, F. J., D’elía, G., Begg, C., Begg, K., Hosoda, T., Campbell, K. L., and Suzuki, H. (2012). Evolutionary and biogeographic history of weasel-like carnivorans (Musteloidea). Molecular Phylogenetics and Evolution, 63(3):745-757.

Scheel, D.-M., Slater, G., Kolokotronis, S.-O., Potter, C., Rotstein, D., Tsangaras, K., Greenwood, A., and Helgen, K. M. (2014). Biogeography and taxonomy of extinct and endangered monk seals illuminated by ancient DNA and skull morphology. ZooKeys, 409:1-33.

Schiaffini, M. I., Gabrielli, M., Prevosti, F. J., Cardoso, Y. P., Castillo, D., Bo, R., Casanave, E., and Lizarralde, M. (2013). Taxonomic status of southern South American Conepatus (Carnivora: Mephitidae). Zoological Journal of the Linnean Society, 167(2):327-344.

Sillero-Zubiri, C. and Gottelli, D. (1994). Canis simensis. Mammalian Species, 485:1-6. 
Slater, G. J., Harmon, L. J., and Alfaro, M. E. (2012). Integrating fossils with molecular phylogenies improves inference of trait evolution . Evolution, 66(12):3931-3944.

Stewart, B. S. and Huber, H. R. (1993). Mirounga angustirostris. Mammalian Species, 449:1-10.

Stirling, I. (1971). Leptonychotes weddelli. Mammalian Species, 6:1-5.

Storz, J. F. and Wozencraft, W. C. (1999). Melogale moschata. Mammalian Species, 631:1-4.

Thomas, J., Pastukhov, V., Elsner, R., and Petrov, E. (1982). Phoca sibirica. Mammalian Species, 188:1-6.

Vanderhaar, J. M. and Hwang, Y. T. (2003). Mellivora capensis. Mammalian Species, 721:1-8.

Verts, B. J., Carraway, L. N., and Kinlaw, A. (1910). Spilogale gracilis. Mammalian Species, 674:1-10.

Wade-Smith, J. and Verts, B. J. (1982). Mephitis mephitis. Mammalian Species, 173:1-7.

Walton, L. and Joly, D. (2003). Canis mesomelas. Mammalian Species, 715:1-9.

Ward, O. and Wurster-Hill, D. (1990). Nyctereutes procyonoides. Mammalian Species, 358:1-5.

Wilson, D. E. and Reeder, D. M. (2005). Mammal species of the world: a taxonomic and geographic reference, volume 1 . JHU Press.

Yensen, E. and Tarifa, T. (1912). Galictis cuja. Mammalian Species, 728:1-8.

Yensen, E. and Tarifa, T. (2003). Galictis vittata. Mammalian Species, 727:1-8.

Youngman, P. M. (1990). Mustela lutreola. Mammalian Species, 362:1-3.

Zrzavy, J. and Ricankova, V. (2004). Phylogeny of recent Canidae (Mammalia, Carnivora): relative reliability and utility of morphological and molecular datasets. Zoologica Scripta, 33(4):311-333. 
Apêndice $F$

\section{Publicações}


1. Simon, M. Machado, F. A. e Marroig, G. (in press). High evolutionary constraints limited adaptive responses to past climate changes in toad skulls. Proceedings of the Royal Society B.

2. Santos, M. M. D., Silva, F. M. D., Hingst-Zaher, E., Machado, F. A., Zaher, H., e Prudente, A. L. D. C. (in press). Cranial adaptations for feeding on snails in species of Sibynomorphus (Dipsadidae: Dipsadinae). Zoology.

3. Carvalho, A. L. G., Sena, M. A., Peloso, P. L. V., Machado, F. A., Montesinos, R. e Silva, H. R., et al. (2016). A new Tropidurus (Tropiduridae) from the Semiarid Brazilian Caatinga: Evidence for conflicting signal between mitochondrial and nuclear loci affecting the phylogenetic reconstruction of South American collared lizards. American Museum Novitates, 3852, 1-68.

4. Bernardo, P. H., Machado, F. A., Murphy, R. W. e Zaher, H. (2012). Redescription and morphological variation of Oxyrhopus clathratus Duméril, Bibron and Duméril, 1854 (Serpentes: Dipsadidae: Xenodontinae). South American Journal of Herpetology, 7(2), 134-148.

5. Fausto, S., Machado, F. A., Bento, L. F. J., Iamarino, A., Nahas, T. R. e Munger, D. S. (2012). Research Blogging: Indexing and registering the change in Science 2.0. Plos One, 7(12), e50109.

6. Molina, F. B., Machado, F. A. e Zaher, H. (2012). Taxonomic validity of Mesoclemmys heliostemma (McCord, Joseph-Ouni Lamar, 2001) (Testudines, Chelidae) inferred from morphological analysis. Zootaxa, 63-77.

7. Sydney, N. V., Machado, F. A. e Hingst-Zaher, E. (2012). Timing of ontogenetic changes of two cranial regions in Sotalia guianensis (Delphinidae). Mammalian Biology - Zeitschrift Fur Saugetierkunde, 77(6), 397-403. 